\title{
Do migrant remittances matter? Nature, determinants and impacts of remittances to Pakistan
}

\author{
Dissertation \\ zur Erlangung des wirtschaftswissenschaftlichen Doktorgrades \\ der Wirtschaftswissenschaftlichen Fakultät \\ an der Universität Göttingen
}

vorgelegt von

Junaid Ahmed

aus Swabi, Pakistan

Göttingen, 2015 
Erstgutacher:

Zweitgutacher:

Drittprüferin:

Tag der mündlichen Prüfung:
Prof. Stephan Klasen, Ph.D.

Prof. Inmaculada Martinez-Zarzoso, Ph. D.

Prof. Thomas Kneib, PhD.

$15 / 06 / 2015$ 
This work is dedicated to those two kind souls all of whose efforts, hopes and prayers have constantly stayed behind my growth and success: my loving parents. 


\section{Acknowledgements}

The completion of this study has been a long journey spanning four years, and it would not have been possible without the special blessing of Almighty Allah, personal efforts and valuable input of several individuals. First and foremost, I am deeply indebted to my supervisors Prof. Stephan Klasen and Prof. Inmaculada Martínez-Zarzoso for their invaluable guidance, support and encouragement throughout my doctoral studies. My utmost gratitude goes to my main supervisor, Prof. Stephan Klasen for accepting to supervise me, his constant guidance, patience, and most notably for his kindness. Every time when I met him, I came out of his office satisfied, confident and with answers to my problems. This is in fact a unique experience for me. Prof. Inmaculada Martínez-Zarzoso timely, frank and pertinent opinion as well as her constructive comments improved my work considerably. There were moments when I was losing faith in my work and was not very confident of my direction, but every time Prof. Inmaculada was a source of confidence for me. I would also like to express my gratitude to Prof. Thomas Kneib for agreeing to be one of the examiners in my final doctoral defense.

I would also like to express my deep appreciation to Dr. Felicitas Nowak-Lehmann and Dr. Elena Groß who has helped me with the data structure and econometric analysis. I also thank Dr. Mazhar Mughal for excellent collaboration in one of my essays. I am also grateful to Jenifer Phillips for her valuable proof-reading. I feel very privileged to have such wonderful and caring colleagues at the chair of Development Economics. I thank all of them for their advice, practical help and friendship.

I also acknowledge the Higher Education Commission (HEC) Pakistan and German Academic Exchange Program (DAAD) whose financial support gave me the opportunity to study in Germany.

My deepest thanks goes to my family for always supporting me and organising things during my absence from home, as well as giving me energy and inspiration. Finally, I would like to thank so many good friends as well as Pakistani community in Göttingen for providing a warm and friendly atmosphere. 


\section{Abstract}

This thesis is a collection of studies, which analyze the macro- and micro-economic aspects of the nature of migrant remittances to Pakistan and their economic impacts on the recipient households' consumption and asset accumulation patterns. We find that international remittances are a stable and stabilizing source of foreign exchange compared with other financial inflows. Moreover, they exhibit a countercyclical behaviour with respect to the home economy, while their association with host economies is mainly acyclical. Remittance flows are crucially determined by transaction costs suggesting that when the cost of remitting is high, migrants either refrain from remitting or employ informal remittance channels.

We find that remittances are perceived as a mainly transient source of revenue by the migrant households, and are therefore spent on the households' human capital enhancement. This effect is subject to the recipient households' income level. Furthermore, international remittances lead to a substantial increase in the household asset stock, whereas no significant change results from the receipt of domestic remittances. Besides, international remittances serve to generate precautionary savings for the recipient households. 
Table of contents

ACKNOWLEDGEMENTS IV

ABSTRACT $v$

CHAPTER 1 :INTRODUCTION 1

1.1. MIGRANT OUTFLOWS AND REMITTANCES TO THE DEVELOPING WORLD 1

1.2. PAKISTAN INTERNATIONAL MIGRATION DYNAMICS: AN OVERVIEW 4

1.3. TRENDS OF REMITTANCES INFLOWS TO PAKISTAN: SOME STYLIZED FACTS 5

1.4. OBJECTIVE OF THE STUDY 6

1.5. SCOPE OF THE STUDY $r$

1.6. ORgANIZATION OF THE THESIS $\quad 8$

$\begin{array}{lr}\text { REFERENCES } & 9\end{array}$

CHAPTER 2 :BLESSING OR CURSE: THE STABILIZING ROLE OF REMITTANCES

COMPARED WITH OTHER FINANCIAL FLOWS

$\begin{array}{ll}\text { AbSTRACT } & 11\end{array}$

2.1. INTRODUCTION

2.2. REMitTANCES, FDI AND ODA FLOWS TO PAKISTAN: SOME STYlized FACTS 14

2.3. FinANCIAL FLOWS AND BUSINESS CYCLE: REVIEW OF THE EMPIRICAL LITERATURE 17

2.4. DATA AND METHODOLOGY 19

2.4.1. DATA DESCRIPTION

2.4.2. Methodology $r 20$

2.4.2.1. TIME SERIES FILTERING $\quad 20$

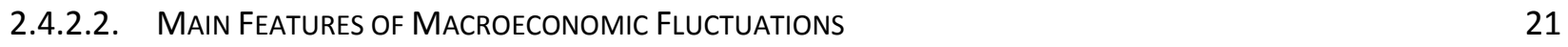

2.4.2.3. SVAR MOdEL SPECIFICATION AND RESTRICTION IDENTIFICATION 22

2.5. MAIN RESULTS

2.5.1. Volatility, CyClicality ANd Stabilization of Financial Flows 26

2.5.2. EMPIRICAL EVIDENCE FROM A SVAR

2.6. DISCUSSION AND CONCLUSIONS

REFERENCES $\quad 38$

APPENDIX

A.2.1 Statistical SignificanCe OF Cross-Correlations 43

CHAPTER 3 :DO TRANSFER COSTS MATTER FOR FOREIGN REMITTANCES? A

GRAVITY MODEL APPROACH $\quad 45$

AbStract $\quad 45$

$\begin{array}{ll}\text { 3.1. INTRODUCTION } & 46\end{array}$ 
3.2. OVERVIEW OF BILATERAL Migration ANd REMitTANCES TO PAKISTAN 48

3.3. COST OF REMITTING TO PAKISTAN

3.4. FACTORS BEHIND BILATERAL REMITTANCES FLOW. A BRIEF LITERATURE REVIEW 53

3.5. EMPIRICAL STRATEGY

3.5.1. GRAVITY MODEL OF BILATERAL REMITTANCES

3.5.2. DATA AND VARIABLE DEFINITIONS

$\begin{array}{ll}\text { 3.5.3. ESTIMATION ISSUES } & 60\end{array}$

3.6. EMPIRICAL FINDINGS

$\begin{array}{lr}\text { 3.7. CONCLUDING REMARKS } & 67\end{array}$

REFERENCES $\quad 69$

$\begin{array}{ll}\text { APPENDIX } & 74\end{array}$

CHAPTER 4 :HOW DO MIGRANT REMITTANCES AFFECT HOUSEHOLD CONSUMPTION

\begin{tabular}{ll} 
PATTERNS? & 75 \\
\hline
\end{tabular}

$\begin{array}{ll}\text { Abstract } & 75\end{array}$

$\begin{array}{ll}\text { 4.1. INTRODUCTION } & 76\end{array}$

4.2. LITERATURE OVERVIEW

$\begin{array}{ll}\text { 4.3. DATA DESCRIPTION } & 79\end{array}$

4.4. EMPIRICAL METHODOLOGY

\begin{tabular}{ll} 
4.4.1. MODEL SPECIFICATION & 83 \\
\hline
\end{tabular}

4.4.1.1. LEAST SQUARES AND TOBIT $\quad 84$

4.4.1.2. PROPENSITY SCORE MATCHING (PSM)

4.5.1. DESCRIPTION OF SELECTED VARIABLES

$\begin{array}{ll}\text { 4.5.1.1. CONSUMPTION VARIABLES } & 88\end{array}$

4.5.1.2. ECONOMIC INDICATORS 9

4.5.1.3. SOCIO-DEMOGRAPHIC INDICATORS

4.5.1.4. LOCATIONAL VARIABLES 92

$\begin{array}{ll}\text { 4.6. FINDINGS } & 93\end{array}$

4.6.1. WORKING LESER ESTIMATIONS

$\begin{array}{ll}\text { 4.6.2. PSM ESTIMATIONS } & 96\end{array}$

$\begin{array}{lr}\text { 4.7. DISCUSSION } & 98\end{array}$

4.8. ROBUSTNESS AND SENSITIVITY CHECKS 100

4.9. CONCLUDING REMARKS 101

REFERENCES $\quad 102$

$\begin{array}{ll}\text { APPENDIX } & 106\end{array}$

CHAPTER 5 :GREAT EXPECTATION? REMITTANCES AND ASSET ACCUMULATION IN

PAKISTAN 
5.1. INTRODUCTION

5.2. REMITTANCES AND ASSET ACCUMULATION - A BRIEF LITERATURE OVERVIEW 115

$\begin{array}{ll}\text { 5.3. DATA DESCRIPTION } & 117\end{array}$

5.4. METHODOLOGY $r 2$

$\begin{array}{lr}\text { 5.4.1. MODEL AND VARIABLE SELECTION } & 120\end{array}$

$\begin{array}{ll}\text { 5.4.2. ECONOMETRIC TECHNIQUES EMPLOYED } & 124\end{array}$

$\begin{array}{ll}\text { 5. 5. KEY FINDINGS } & 126\end{array}$

5.6. ESTIMATION QUALITY AND ROBUSTNESS CHECKS 130

$\begin{array}{ll}\text { 5.6.1. QUALITY AND SENSITIVITY DIAGNOSTICS } & 130\end{array}$

5.6.2. ROBUSTNESS MEASURES 132

5.7. CONCLUSION

REFERENCES $\quad 136$

$\begin{array}{lr}\text { APPENDIX } & 140\end{array}$

\begin{tabular}{lr} 
CHAPTER 6 : CONCLUSION & 146 \\
\hline
\end{tabular} 


\section{List of Tables}

Table 2.1. Remittances and other resource flows into developing countries (USD billions) ..................... 12

Table 2.2. Descriptive statistics....................................................................................................... 20

Table 2.3. Summary of Cross Correlations between Sending-Country and Pakistani Output at Time $t$ and

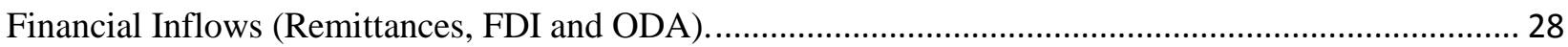

Table 2.4. Stabilizing or destabilizing impact of financial flows with regard to output when they are pro or

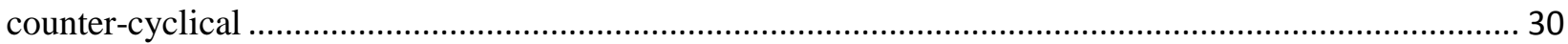

Table 2.5. Stabilizing nature of remittances, ODA and FDI with respect to Output................................ 31

Table 2.6. Error Variance Decomposition: Percentage of Variation in Capital Inflows Explained by

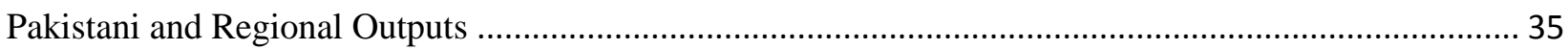

Table A2.7. ADF Test Results for Unit Root Tests ........................................................................... 44

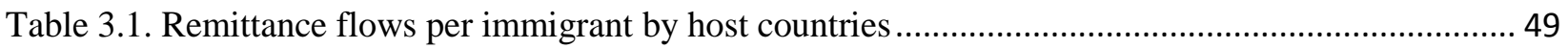

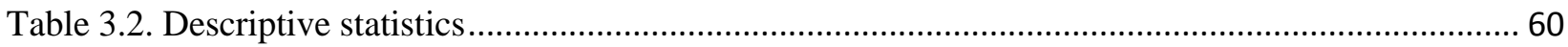

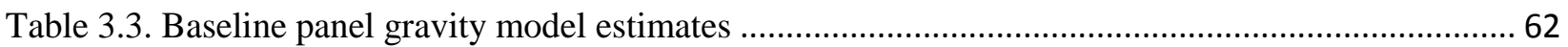

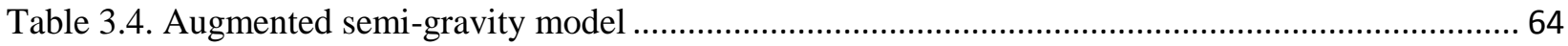

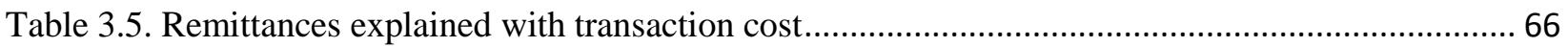

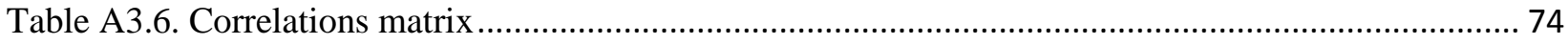

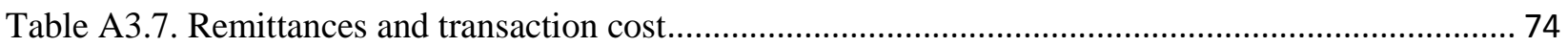

Table 4.1. Household Profile by Access to Remittances....................................................................... 81

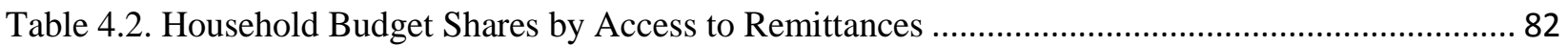

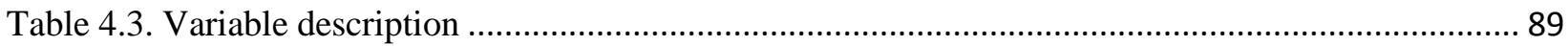

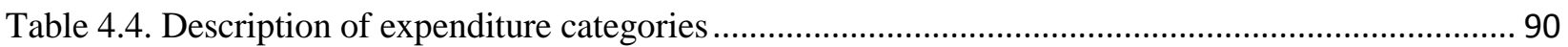

Table 4.5. Remittances and household consumption (OLS and Tobit estimations) .................................. 94

Table 4.6. Marginal Budget Shares by Access to remittances ................................................................ 95

Table 4.7. Marginal Budget Shares - Poor households ...................................................................... 96

Table 4.8. Marginal Budget Shares - Non-poor households .................................................................. 96

Table 4.9. Remittances and household budget shares (Propensity Score Matching) ............................... 97

Table 4.10. Remittances and household consumption (Entropy balancing) .......................................... 100

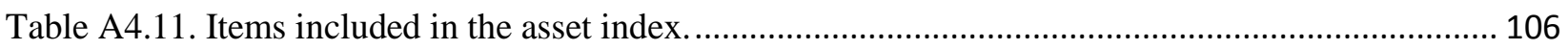

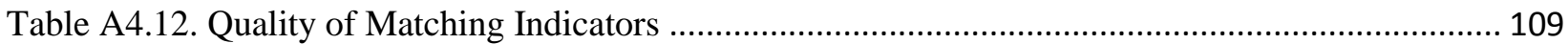

Table A4.13. Remittances and Budget Shares - Non-poor households (Propensity Score Matching)...... 110

Table A4.14. Remittances and Budget Shares - Poor households (Propensity Score Matching)............. 111

Table A4.15. Rosenbaum bounds sensitivity analysis. Foreign remittances as treatment variable .......... 112

Table A4.16. Rosenbaum bounds sensitivity analysis. Domestic remittances as treatment variable....... 112

Table 5.1. Profiles of remittance recipient and non-recipients .......................................................... 118

Table 5.2. Household assets by access to remittances............................................................................. 119

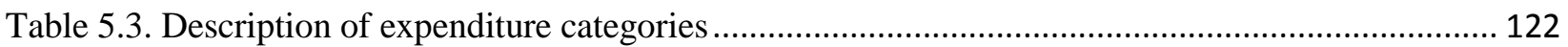

Table 5.4. Remittances and household assets: Bivariate statistics ....................................................... 122

Table 5.5. Remittances and asset categories (Propensity Score Matching) ........................................... 126

Table 5.6. Remittances and asset categories: Urban households (Propensity Score Matching) ............... 128

Table 5.7. Remittances and assets categories: Rural households (Propensity Score Matching) ............... 129 
Table 5.8. Remittances and asset categories: Poor and non-poor households (OLS estimates)............... 130

Table 5.9. Rosenbaum bounds sensitivity analysis: Foreign remittances ............................................ 131

Table 5.10. Remittances and household assets (Entropy balancing) ................................................. 132

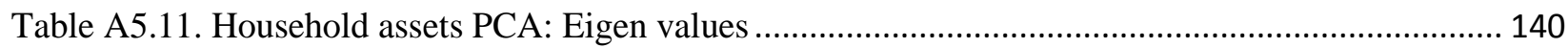

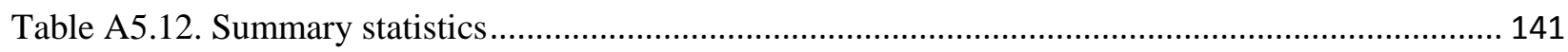

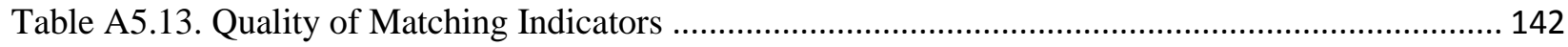

Table A5.14. Remittances and asset categories (OLS estimates) ........................................................ 143

Table A5.15. Remittances and asset categories: Urban households (OLS estimates)............................ 144

Table A5.16. Remittances and assets categories: Rural households (OLS estimates) ........................... 145

\section{List of Figures}

Figure 1.1. Top ten destinations of migrant stocks (2000-2013) in millions .......................................... 1

Figure 1.2. Top ten recipient of remittances (2013) in billions USD .................................................... 2

Figure 1.3.Top ten recipient of remittances as a share of GDP (2013) ................................................. 3

Figure 1.4.Trends of Remittances inflows to Pakistan (1976-2013) ..................................................... 6

Figure 2.1. Remittances and other resource flows to Pakistan (USD millions) ....................................... 15

Figure 2.2. Remittances and other resource flows as a share of GDP to Pakistan ................................. 15

Figure 2.3.Top remittance sending regions (USD millions) ............................................................ 16

Figure 2.4.Volatility of Financial Inflows to Pakistan, 1974-2011 ..................................................... 26

Figure 2.5. Response of Remittances, ODA and FDI to Shocks to Middle East and Pakistani Output...... 32

Figure 2.6. Response of Remittances, ODA and FDI to Shocks to North American and Pakistani Output 33

Figure 2.7. Response of Remittances, ODA and FDI to Shocks to European and Pakistani Output.......... 33

Figure 2.8. Response of Remittances, ODA and FDI to shocks to Asia Pacific and Pakistani Output....... 34

Figure 3.1. Average cost for sending remittances (as a share of funds sent) to Pakistan from major

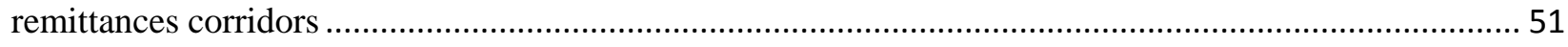

Figure 3.2. Comparison of geographical distance and transaction cost of remittances to Pakistan from

selected host countries, 2013).................................................................................................... 53

Figure A4.1. Density distributions for the estimated propensity scores for foreign remittance receiving and

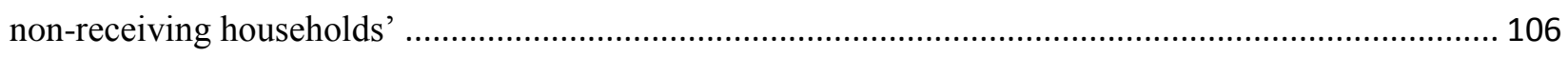

Figure A4.2. Density distributions for the estimated propensity scores for domestic remittance receiving and non-receiving households' .................................................................................................. 107

Figure A4.3 Pre- and post-matching bias reduction for different Matching estimations (Foreign

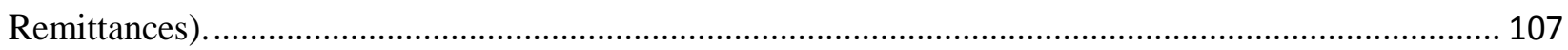

Figure A4.4. Pre- and post-matching bias reduction for different Matching estimations (Domestic

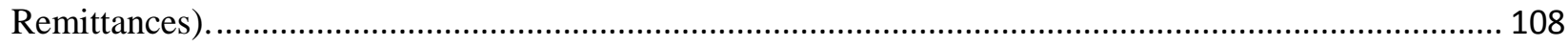




\section{Chapter 1 :Introduction}

\subsection{Migrant outflows and remittances to the developing world}

International migration, the movement of people across global frontiers, has major economic, cultural and demographic implications in both destination and origin countries. In 2013, the number of international migrants reached 232 million in 2013, up from 175 million in 2000 and 154 million in 1990.(United Nations, 2013).The worldwide stock of international migrants accounts for a relatively small share of total population, comprising around 3.2 percent of the world's population. The largest number of international migrants, about 46 million resided in the United States of America, equal to 19.8 percent of the global migrants (Figure 1.1).The second largest concentration of migrants worldwide (11 million) is found in the Russian Federation, followed by Germany (10 million) and Saudi Arabia (9 million), while United Arab Emirates and the United Kingdom both host 8 million international migrants.

Figure 1.1. Top ten destinations of migrant stocks (2000-2013) in millions

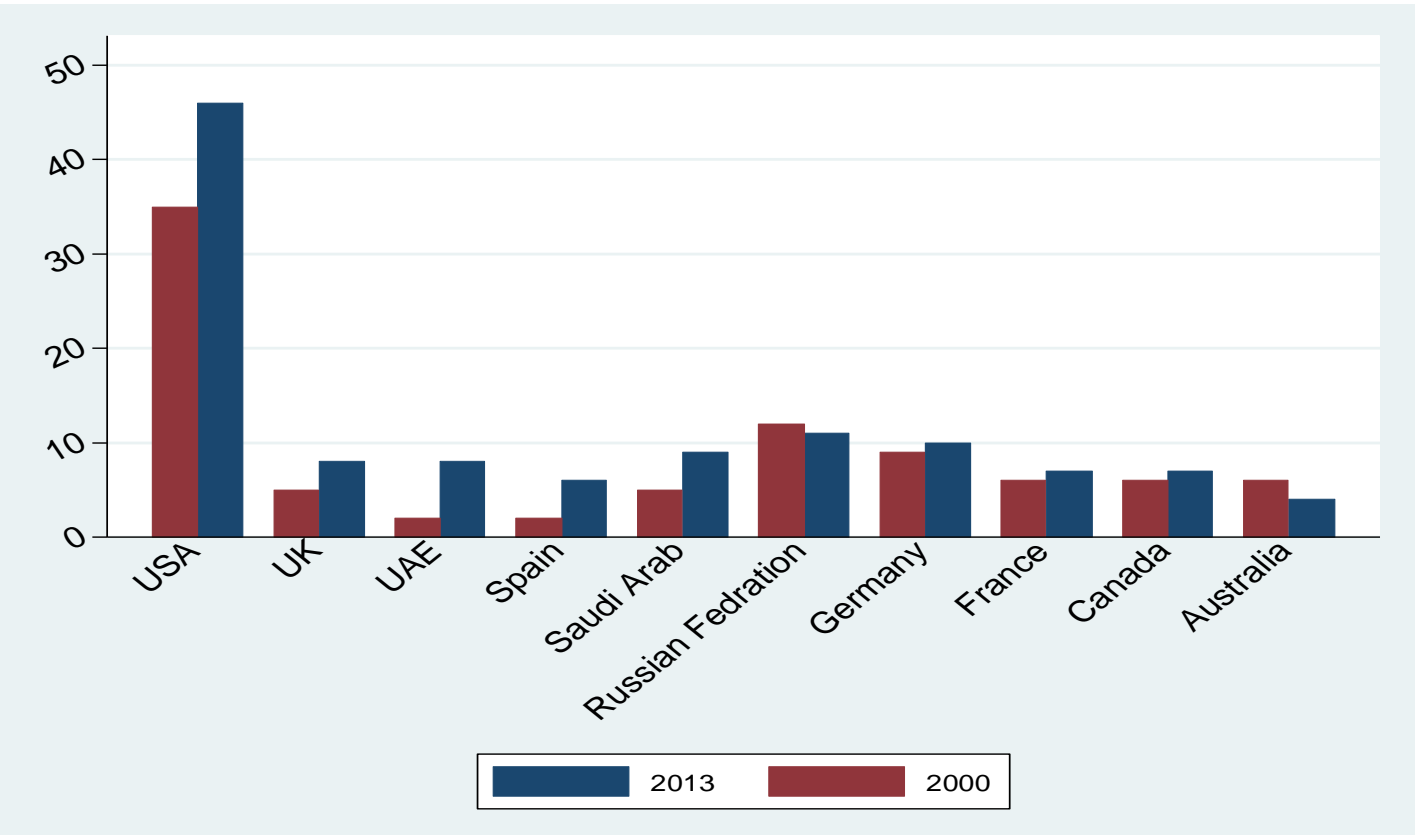

Source: United Nations, Department of Economic and Social Affairs (2013) 
Migrant sending developing countries also benefit from migration in form of remittances, which are considered to be an important source of foreign exchange for many developing countries. Remittances represent the proportion of emigrants income earn abroad that is send to their countries back home. The flow of official remittances sent to developing countries has increased more than tenfold over the last decade. The amount reached $\$ 404$ billion in 2013, growing by 3.5 percent compared with 2012 (World Bank, 2014b).

Figure 1.2. Top ten recipient of remittances (2013) in billions USD

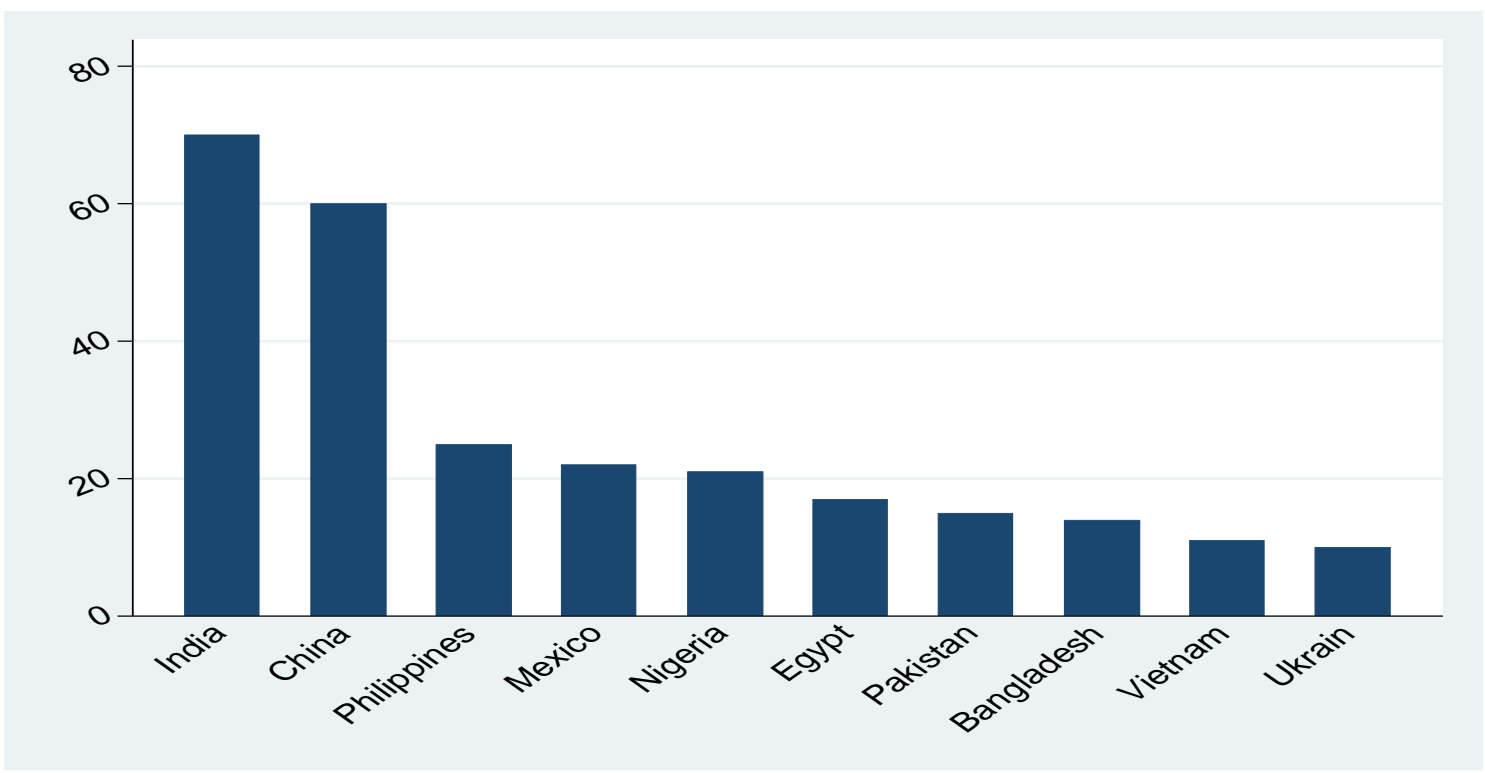

Source: World Bank (2014)

Among the recipients, about $\$ 70$ billion worth of recorded remittances go to India (see Figure 1.2), while China receives about $\$ 60$ billion of remittances. The two countries' together account for almost one-third of the total amount of remittances sent to all the developing countries in 2013. In the third place Philippines receive about $\$ 25$ billion followed by Mexico with $\$ 22$ billion, Nigeria with $\$ 21$ billion, Egypt with $\$ 17$ billion, Pakistan with $\$ 15$ billion, Bangladesh with $\$ 14$ billion, Vietnam with $\$ 11$ billion and Ukraine with $\$ 10$ billion.

Remittances are especially considered as a vital source of development finance for small and poor countries with a larger Diaspora tend to be much more dependent on this flow. 
Figure 1.3.Top ten recipient of remittances as a share of GDP (2013)

(in percent of GDP)

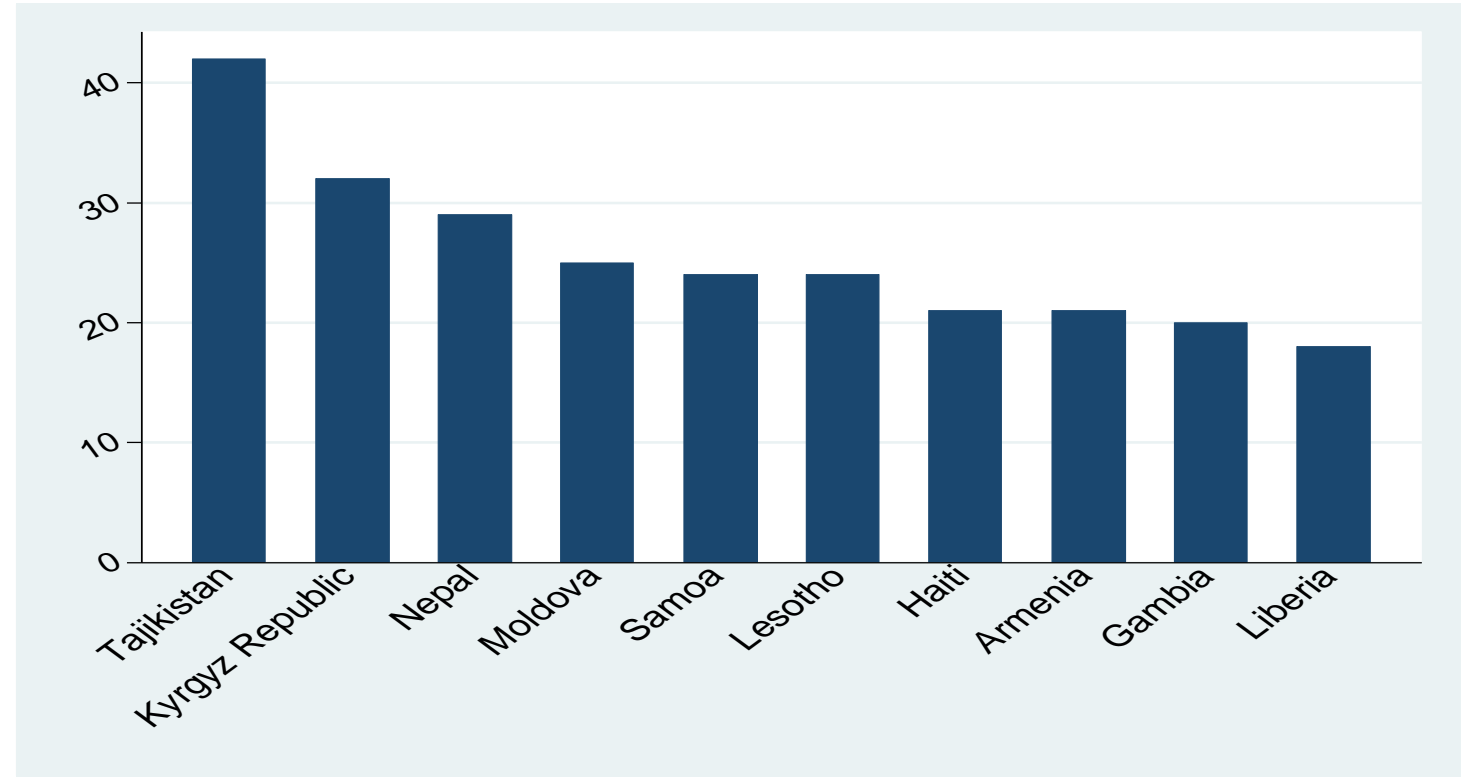

Source: World Bank (2014)

As shown in Figure 1.3 the top recipients in 2013 relative to the GDP were Tajikistan (52 percent), Kyrgyz Republic (31 percent), Nepal and Moldova (both 25 percent), Samoa and Lesotho (both 23 percent), Armenia and Haiti (both 21 percent), Liberia (20 percent) and Kosovo (17 percent).

Remittances are increasingly becoming a vital source of foreign exchange earnings for many developing countries after Foreign Direct Investment (FDI), and surpass Official Development Assistance (ODA). Moreover, these remittance flows have proved remarkably resilient compared to other resource flows (Ratha, 2003; Mughal and Makhlouf, 2011). Similarly, remittances are more important during recessive phases in the economic cycle, as migrants send more money to support their families back home (Orozco, 2003; Ratha, 2007). This is important from a development country perspective, where remittances are used directly to finance household's consumption. Remittances may therefore smooth consumption and contribute to the stability of recipient economies (World Bank, 2006). Moreover, remittances generate several important contributions to economic development such as improved access to education and health services, tend to reduce poverty and enhanced financial sector development, as well as several multiplier 
effects through higher household expenditures (De, et.al, 2015). Therefore, remittances could be welcomed, encouraged, and facilitated. Despite of the expected benefits of this flow, it is also believed that remittances may induce conspicuous consumption and discourage labor supply (Rapoport and Docquier, 2006), thus have minimal impact on country development.

\subsection{Pakistan international migration dynamics: An overview}

Pakistan has a long history of international migration. After independence in 1947, a number of Pakistanis migrated for short-term to the United Kingdom and the United States. The first major wave of migration from Pakistan began in the 1970s when thousands of Pakistani workers left for the states of the Persian Gulf to participate in the development of the newly-rich oil economies. In 2013, about 5.7 million Pakistani immigrants resided abroad, compared with 3.7 million in 2000 and 3.6 million in 1990 (UN, 2013). This shows that 54 percent of this recorded growth in migrants stock took place during the period 2000-2013. Factors that led to this wave of migration include economic slowdown, increasing poverty, rapid population growth and substantial wage differentials (Ministry of Finance, 2013; Irfan, 1999). According to the UN, Middle East is the most popular regional destination with 2 million Pakistani migrants, followed by half a million each in North America, Europe, and Asia Pacific. In the Middle East, Saudi Arabia and the United Arab Emirates (UAE) host the largest Pakistani migrant communities, in part due to geographical proximity and cultural closeness. Moreover, the region also has attracted a large proportion of immigrants due to the availability of medium- and low-skilled jobs (Arif, 2009). Migration to the Persian Gulf is mostly temporary in nature and workers are usually young and low-skilled males (Gazder, 2003; Arif, 2009), coming from a rural, low-income family background (Azam, 1991; Addleton, 1992). These migrants lack not only the financial resources required for distant migration, but also the education and skills required in the labor markets in high-income countries. In contrast, migrants to Western countries are often highly educated and come from well-off households (Gazder, 2003). These migrants have the possibility to bring their families with them, ultimately leading to permanent settlement in those countries. For this type of migration, emigrants predominantly migrate to the USA, Canada and the UK. The presence of such a significant number of immigrants has not only accelerated the integration of Pakistan in the world economy, but as a result, has led Pakistan to become one of the top ten recipients of remittances in the world. 


\subsection{Trends of remittances inflows to Pakistan: Some Stylized Facts}

The Pakistani economy is passing through a challenging phase with a chronic energy crisis, persistent inflation, food insecurity, lawlessness and international debt. However, the remittances sent by millions of Pakistani migrants around the world have so far proved a constant bright light. Remittances sent by Pakistani migrants have grown sharply during the last decade. The inflow of remittances has surpassed that of FDI and ODA becoming the second largest source of foreign exchange after the country's exports (WDI, 2014). The flows reached $\$ 14$ billion in 2013, compared with $\$ 1$ billion in 2001 (State Bank of Pakistan, 2014) ${ }^{1}$. This is equivalent to 6.3 percent of the country's annual national output (Figure 1.4). Moreover, the fraction of households receiving remittances is around 5.4 percent as reported in the HIES, 2010-11. Remittance flows to Pakistan are reported to have helped cushion the economy against severe current account deficits. They have alleviated poverty and reduced inequality (Mughal and Anwar, 2012). The government is increasingly relying on these flows (Mughal, 2012) given the fact that other financial and capital flows are not forthcoming.

Remittances to Pakistan first gained importance in the 1970s (Figure 1.4), when the oil exporting economies of Persian Gulf began to receive thousands of Pakistani workers to work in the rapidly growing construction work. Remittances increased sharply to reach 10\% of Pakistan's GDP in 1982-83 (Figure 1.4). The ensuing fall in oil prices and the consequent slowing down of construction projects led to a gradual decline in remittances. The second and ongoing phase of official remittances growth began in the aftermath of the terrorist attacks of September 11, when in the financial year 2001-02 remittances to Pakistan more than doubled. The spectacular rise in remittance flows can be partly attributed to curbs on informal remittance-transferring channels (e.g Hundi or Hawala), more convenient formal remittance services, growing Pakistani Diaspora, improving skill level of immigrants (Amjad et. al.,2013). Other reasons include panic transfers in the immediate aftermath of Sep 2001 attacks and Pakistani migrants' continued interest in the country's development.

\footnotetext{
${ }^{1}$ Traditionally, the recorded remittance flows have been underestimated due to the use of unofficial channels. In case of Pakistan, about half of the remittances are have been reported to be transferred through informal remittances channel (Amjad et.al, 2012; Arif , 2009 ; Suleri and Savage, 2006)
} 
Figure 1.4.Trends of Remittances inflows to Pakistan (1976-2013)

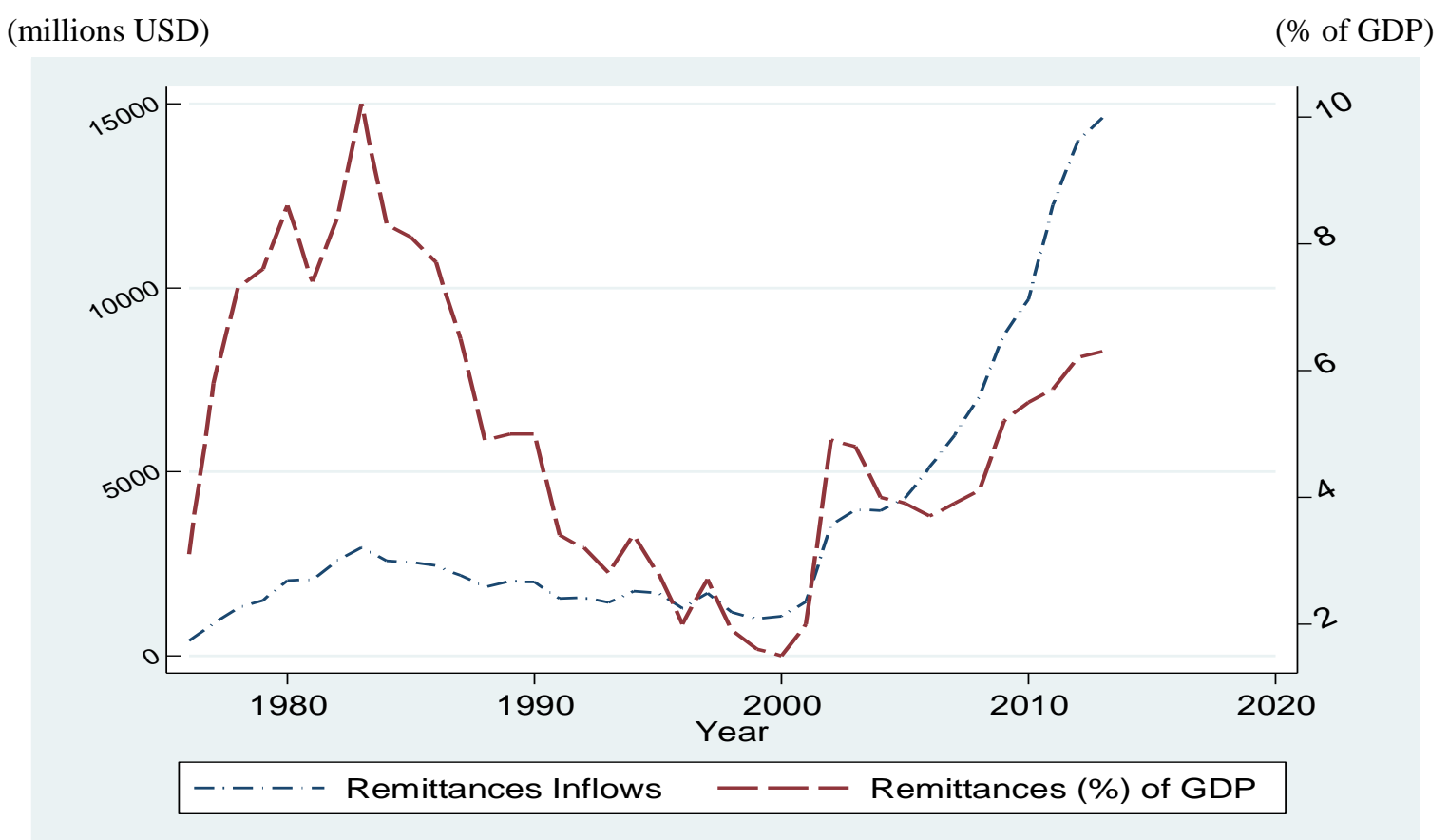

Source: World Development Indicator, 2014

This continuing growth phase has seen a sharp and sustained rise in remittance flows from all major Pakistani migrant communities around the world.

Country-wise, remittance distribution shows that Saudi Arabia, the USA, the UAE, and the UK represent Pakistan's main remittance sending countries. The Middle East region is the dominant source of remittances, which on average accounts for more than 60 percent of overall remittances, mainly sent from Saudi Arabia and the UAE (State Bank of Pakistan, 2014). However, remittances per immigrant portray a somewhat different picture, with more flows coming from developed nations such as the USA, Australia, and the UK.

\subsection{Objective of the study}

In view of their sizeable amount and growing importance for the country, the objective of this work is to study the role of migrant remittances in economic development of the recipient economy. We first provide the nature of these flows, their main determinants as well as their impact on the welfare of the households. The aim is to understand the way in which foreign remittances have fared, their channels of interaction with the home economy, and evaluate their 
potential for the country's development. In the light of this analysis, we can point out ways in which the positive effects of remittances on the economy can be increased.

We first assess the stylized facts of the cyclicality of migrants' remittances, ODA and FDI employing annual time series data over the period 1974-2011, and study the nature of remittance flows. We explore to what extent these financial flows neutralize macroeconomic shocks and contribute to macroeconomic stability in the country. Moreover, we examine these flows with respect to the business cycles of major remittances sending economies. If remittances are found to be pro-cyclical with respect to the sending economy, then remittances could serve as another channel through which economic fluctuations in the sending regions impact the economic conditions of the country. Secondly, we examine the factors driving the flows of remittances to Pakistan. In particular, we aim to evaluate the importance of transaction cost and migration networks in driving remittance inflows. In order to examine these questions, we use data on bilateral remittances to Pakistan from 23 major remittance-sending countries for the 2001-2013 period. Once the nature and characteristics of foreign remittances are better understood, we seek to examine the impact of these flows on household's consumption pattern and assets accumulation in order to find answers for several questions. Firstly, we analyze how remittances are employed by the receiving households and whether consumption patterns of remittancerecipients and non-recipients differ. Secondly, the consumption behaviour of households receiving international and domestic remittances is compared and whether these patterns vary with respect to the households' income level is evaluated. Thirdly, we investigate whether remittances lead to an increase in the household's asset stock and whether the positive or negative impact of remittances on asset accumulation hide a more nuanced image when assets are disaggregated into various subcategories (e.g. durable goods, housing, financial assets and productive assets). Fourthly, the question whether this remittance behaviour differ between foreign and domestic senders is consider. Next, we ask whether the acquisition of assets by recipient households differ between rural and urban and between households living below and above the poverty line and finally, the influence of the amount of remittances on asset holdings of the recipient households is questioned. 
These questions are examined using representative a household survey carried out in Pakistan in 2010-11. As a result of these analyses, we should be able to better discern the potential of migrant remittances to serve as a tool for economic development of the country.

\subsection{Scope of the Study}

Migration and the associated monetary flows are vast areas of research in social and behavioural sciences as Anthropology, Economics, Psychology and Sociology. Only economic aspects of migrant remittances are examined in this thesis. Topics studied pertain to the nature, determinants and consumption and asset accumulation effects of remittances. The first two of these areas of investigation are analyses of a macroeconomic nature, which employ data on official remittance inflows to Pakistan. Parts of remittances to developing countries such as Pakistan are transferred using informal means (e.g. handcarry, informal money transferring operators). We do not take these transfers into account and focus our attention on the officially remitted amounts of money. The other two empirical works are household-level analyses which use binary variable for remittance coming from formal as well as informal sources. This variable takes the values of one or zero depending on whether or not the migrant household receives remittances. The two microeconomic analyses are based on cross-sectional surveys and therefore do not examine dynamic aspects of remittances' effects on the household spending habits.

\subsection{Organization of the thesis}

The rest of the thesis is organized as follows. Chapter 2 to 5 present empirical analyses that can stand alone, each investigating a different area of research. After providing a brief overview, chapter 2 does a comparative analysis of the stylized facts of the cyclical properties of migrants' remittances, ODA and FDI. We explore to what extent these financial flows neutralize macroeconomic shocks and contribute to macroeconomic stability. Chapter 3 deals with the importance of transaction cost and migration networks in attracting remittances. The interaction between remittances and households consumption patterns is analyzed in chapter 4, while the link between remittances and assets accumulation is discuss in chapter 5. Finally, chapter 6 sums up the discussion and considers policy implications. 


\section{References}

Addleton, J.S. (1992). Undermining the centre: The Gulf migration and Pakistan. Oxford University Press.

Amjad, R., Irfan, M., \& Arif, G. M. (2013). How to increase formal inflows of remittances: An analysis of the remittance market in Pakistan. International Growth Center, WP.

Amjad, R., Arif, G. M., \& Irfan, M. (2012). Preliminary study: Explaining the ten-fold increase in remittances to Pakistan 2001-2012. Working Papers \& Research Reports, 2012.

Arif, G. M. (2009). Economic and social impacts of remittances on households' : The case of Pakistani migrants working in Saudi Arabia. Pakistan Institute of Development Economics.

Azam, F. (1991). Labor Migration from Pakistan: trends, impacts and implications. Regional Development Dialogue 12(3): 53-71.

Black, R., and Skeldon, R. (2009). Strengthening data and research tools on migration and development, International Migration, 47(5), 3-22(20).

De,S., Islamaj,E., Kose, A., Ratha \& D. Reza, S. (2015). Can remittances help promote consumption stability? In Global Development Finance 2015, the World Bank, Washington D.C.

Gazdar. H (2003). A review of migration issues in Pakistan. Paper presented at the regional conference on migration, development and pro-poor policy choices in Asia. Dhaka

Irfan, M (1999). Emigration from Pakistan-1947-97 (No. 38623). University Library of Munich, Germany.

Ministry of Finance, Government of Pakistan (2013). Pakistan Economic survey 2012-13. Government of Pakistan, Islamabad.

Malik, A. (2009). Quality and coordination of official development Aid in Pakistan, Working Paper 11. Washington, DC: Wolfensohn Center for Development.

Mughal, M.Y. (2012). Remittances as development strategy: Stepping stones or slippery slope?” Journal of International Development, 24(8)

Mughal, M.Y. and Anwar, A.I. (2012). Remittances, inequality and poverty in Pakistan: Macro and microeconomic evidence. Working Papers 2012-2013_2, CATT UPPA - Université de Pau et des Pays de l'Adour.

Mughal, M.Y. and Makhlouf, F. (2011). Volatility of remittances to Pakistan: What do the data tell?. Economics Bulletin, 31:1, pp. 605-612. 
Rapoport, H., \& Docquier, F. (2006). The economics of migrants' remittances. Handbook of the economics of giving, altruism and reciprocity,2, 1135-1198.

Ratha, D. (2003). Workers' Remittances: An important and stable source of external development finance. Global Development Finance, The World Bank, Washington D.C.

(2007). Leveraging remittances for development. Policy Brief, Migration Policy Institute, Washington DC.

Suleri, A., and K. Savage. (2006). Remittances in crisis: A case study from Pakistan. Humanitarian Policy Group, Overseas Development Institute, London.

State Bank of Pakistan (2014), Country-wise workers' remittances http://www.sbp.org.pk/stats/survey/index.asp

Orozco, M. (2003). Worker remittances in the international scope. Inter- American Dialogue Working Paper, commissioned by the Multilateral Investment Fund.

United Nations (2013). Trends in international migrants stock. Department of Economic and Social Affairs.

WDI (2014). World Development Indicators. Online Database, World Bank.

World Bank (2006). Global economic prospects: economic implication of remittances and migration. Washington, D C World Bank. 


\title{
Chapter 2 :Blessing or Curse: The stabilizing role of remittances compared with other financial flows
}

Joint work with Inmaculada Martinez-Zarzoso ${ }^{\dagger}$

\begin{abstract}
Flows of remittances to Pakistan are being increasingly viewed as a relatively attractive source of external finance, which can help to foster development and manage economic shocks. Remittances have become a major source of revenue, surpassing the volume of foreign direct investment (FDI) and official development assistance (ODA) that the country receives. This study focuses primarily on the stability, cyclicality and stabilization impacts of remittances to Pakistan. It is evident that foreign flows exhibit different types of volatility; remittances are found to be a less volatile source of external finance than FDI and ODA; they are also found to be counter-cyclical and stabilizing, thus serving to stabilize the recipient economy in times of economic downturns. ODA appears to be a-cyclical and stabilizing, whereas FDI emerges as procyclical and destabilizing. Furthermore, remittances are insensitive to cyclical fluctuation in the sending countries. We also consider an SVAR-based identification in order to examine the responses of financial flows to innovation in receiving and sending economies. We confirm the counter-cyclical mechanism of remittances with respect to Pakistani output. In particular, our results indicate that remittance flows to Pakistan are mainly explained by the economic conditions in the country.
\end{abstract}

Keywords: Remittances, FDI, ODA, Business Cycle, Pakistan.

JEL Codes: E32, F15, F21, F22, F35

\section{Acknowledgment}

The authors gratefully acknowledge the comments and suggestions made by Prof. Stephan Klasen. We also would like to thank the participants at the $16^{\text {th }}$ IZA summer school in Labour Economics, 3rd International Conference in Economics, Eskishier as well as the $15^{\text {th }}$ Göttingen Workshop for International Economics for their helpful comments and discussion.

\footnotetext{
${ }^{\dagger}$ Department of Economics, University of Göttingen, Germany and University Jaume I in Castellón, Spain.
} 


\subsection{Introduction}

During the last decade, the flow of remittances has increased rapidly and now constitutes one of the largest sources of external development finance for many developing countries. Recorded remittance flows to developing countries are estimated to have reached $\$ 406$ billion in 2012, a 6.5 percent increase from $\$ 381$ billion in the preceding year (World Bank, 2012). Remittances are the second largest source of foreign exchange earnings for developing countries after Foreign Direct Investment (FDI), and surpass Official Development Assistance (ODA). Moreover, these remittance flows have proved remarkably resilient compared to other resource flows. For instance, remittances dropped by 4.5 percent in 2009 during global financial crises but rebounded in 2010. In contrast, FDI declined by 32.8 percent from 2008 to 2009 (see Table 2.1).

Table 2.1. Remittances and other resource flows into developing countries (USD billions)

\begin{tabular}{lcccccccc}
\hline \multicolumn{1}{c}{ Resource flows } & 1995 & 2005 & 2006 & 2007 & 2008 & $\mathbf{2 0 0 9}$ & 2010 & 2011 \\
\hline Migrant Remittances & 54 & 198 & 232 & 286 & 331 & $\mathbf{3 1 6}$ & 341 & 381 \\
\hline Foreign Direct Investment & 95 & 307 & 398 & 559 & 637 & $\mathbf{4 2 8}$ & 583 & 644 \\
\hline Private debt and Portfolio Equity & 59 & 193 & 277 & 429 & 186 & $\mathbf{1 8 0}$ & 284 & 201 \\
\hline Official Development Assistance & 57 & 108 & 107 & 108 & 127 & $\mathbf{1 2 6}$ & 130 & - \\
\hline
\end{tabular}

Source: World Bank (2012)

Some studies find that remittances tend to rise during recessive phases in the economic cycle, as migrants send more money home to support their families (Orozco, 2003; Ratha, 2007). Remittances may therefore smooth consumption and contribute to the stability of recipient economies (World Bank, 2006). In contrast, other private financial flows frequently move procyclically, raising income in good times and decreasing it in bad times (Ratha, 2003). The hypothesis of remittances being counter-cyclical is based on the evidence that a large portion of remittance transfers is intended for altruistic purposes (e.g. Agarwal and Horowitz, 2002), but it could also be because household members migrate as part of a risk-diversification strategy against income shocks (Yang and Choi, 2007). Chami, Fullenkamp, and Jahjah (2005) also support the view that altruism of migrants is the underlying reason for the counter-cyclicality of remittances. The fact that remittances rose sharply after the economic crises in countries like Indonesia (1997), Ecuador (1999) and Argentina (2001) seems to support this view (Spatafora, 
2005). World Bank (2006) points out that remittances increased after natural disasters in Bangladesh, Haiti, Honduras and the Dominican Republic, as well as in response to conflicts in Albania and in Sierra Leone. Remittances also help households cope with natural catastrophes (Suleri and Savage, 2006).

Moreover, remittances can also be destined for investment in recipient countries (Woodruff and Zenteno, 2001), generally called the portfolio approach. According to this approach, remittances are supposed to increase when the expected returns of these transfers rise in receiving countries (El-Sakka and McNabb, 1999; Hysenbegasi and Pozo, 2002). Ratha (2003) mentioned that remittance receipts in Turkey and the Philippines declined after the financial crises in the late 1990s, although the decline was marginal compared to other capital inflows. In the same vein, Lueth \& Ruiz-Arranz (2008) reported that remittances do not seem to increase in the wake of natural disasters. However, if altruism dominates, migrants are expected to transfer more money during economic crises to compensate for the decrease in income suffered by the family left behind (Quartey, 2007; Yang and Choi, 2007).

The Pakistani economy has been passing through a challenging phase with energy crisis, persistent inflation, food insecurity, lawlessness and international debt. However, remittances sent by about six million Pakistani migrants around the world have so far proved to be a constant bright star. Pakistan is among the top ten remittance receiving countries in the world and those remittances sent by Pakistani migrants from around the world have grown sharply in the recent years. Remittance flows to Pakistan are reported to have helped cushion the economy against severe current account deficits. Mughal and Anwar (2012) report that they have alleviated poverty and reduced inequality. As a result the government is increasingly relying on these flows (Mughal, 2012) given the fact that other financial and capital flows are not forthcoming.

It is thus of utmost importance to know the character of the driving forces behind the cyclical behavior of these sources of foreign exchange. Are they pro-cyclical, i.e. moving in the same direction as the economy, counter-cyclical, i.e. moving in the opposite direction as the receiving economy, or a-cyclical, i.e. having no association with economic performance? This study attempts to find the cyclical properties of remittance inflows in comparison with alternative sources of foreign inflows. Although some previous studies exist on the business cycle properties 
of financial flows to developing countries, ${ }^{2}$ to our knowledge, only two studies have compared the behavior of various flows. Vargas-Silva (2008) compared remittances and FDI, while Neagu and Schiff (2009) compared the cyclicality, stability and stabilization impacts of remittances with FDI and ODA. To the best of our knowledge, this study is the first to present a comprehensive and comparable empirical analysis of financial flows in the context of Pakistan.

The main goal of the study is to assess the stylized facts of the cyclicality of migrants' remittances, ODA and FDI employing annual time series data over the period 1974-2011. We explore to what extent these financial flows neutralize macroeconomic shocks and contribute to macroeconomic stability in the country. Moreover, we examine these flows with respect to the business cycles of major sending economies. It is pertinent to understand this because if migrant remittances are pro-cyclical with respect to the sending economy, then remittances could be another channel through which economic fluctuations in the regions impact the economic conditions of the country. In order to achieve the abovementioned goals, we employ different filtering techniques and obtain Impulse Response Functions (IRF) by estimating a Structural Vector Autoregressive (SVAR) model to evaluate the extent to which migrant remittances respond to cyclical fluctuations in Pakistan's and sending countries' output in comparison to ODA and FDI.

The rest of the paper proceeds as follows: Section 2 documents the stylized facts of capital inflows to Pakistan. Section 3 discusses the data and methodology. Section 4 presents a comprehensive assessment of our main findings and Section 5 contains the concluding remarks.

\subsection{Remittances, FDI and ODA flows to Pakistan: Some Stylized Facts}

During the last decade, remittances to Pakistan have grown significantly. The flow of remittances has surpassed that of FDI and ODA (Figure 2.1), becoming the second largest source of foreign exchange after the country's exports.

\footnotetext{
${ }^{2}$ For instance, Giuliano and Ruiz-Arranz (2009), Akkoyunlu and Kholodilin (2008), Sayan and Tekin-Koru (2010), Ahmed (2012), Lueth and Ruiz-Arranz (2007) and Barjas et.al (2012) on the cyclical nature of remittances and Bulir and Hamann (2003), Chauvet and Guillaumont (2009) and Pallage and Robe (2001) on foreign aid.
} 
Figure 2.1. Remittances and other resource flows to Pakistan (USD millions)

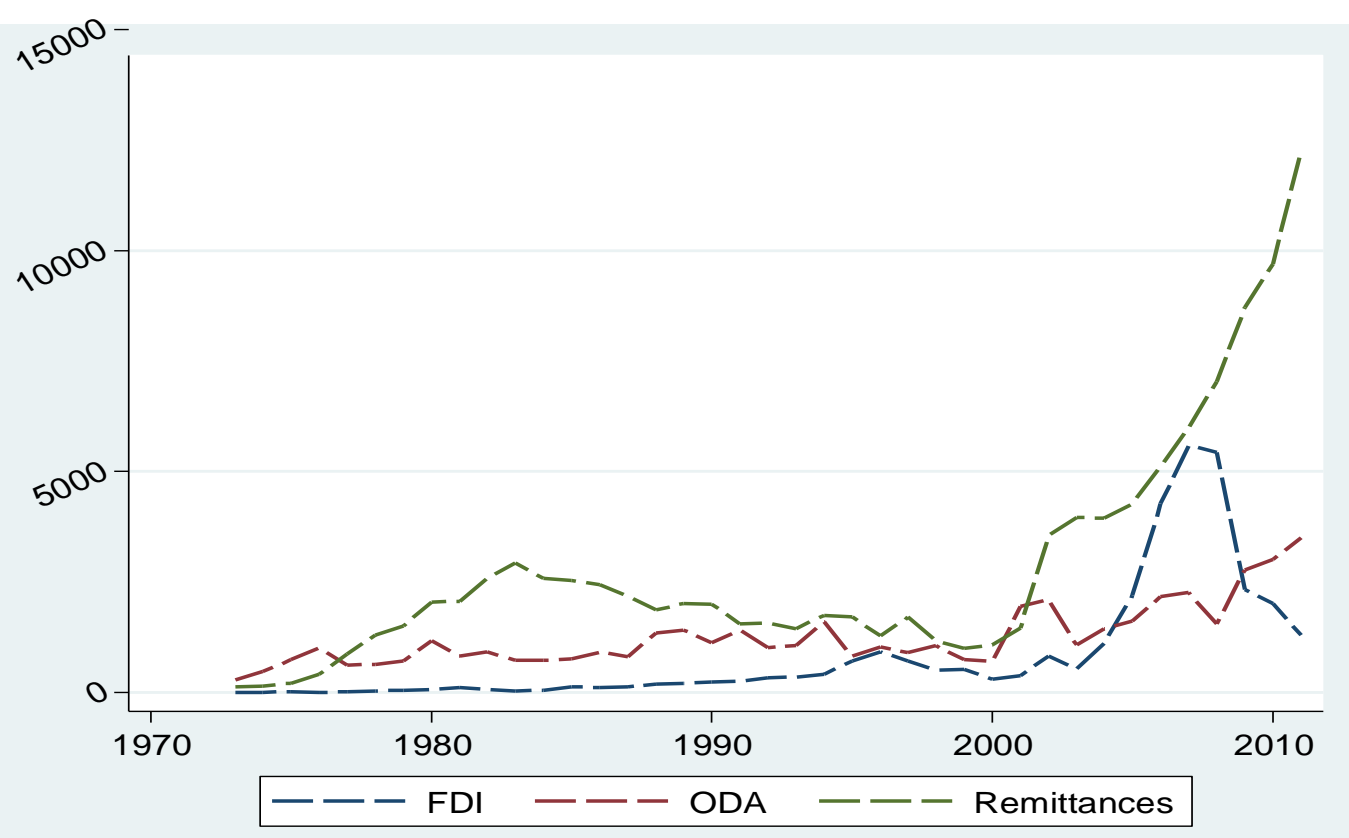

Source: WDI and OECD (2013)

Recorded remittances rose from less than $\$ 1$ billion in 2000 to $\$ 12$ billion in 2011, equivalent to 6 percent of GDP (Figure 2.2).

Figure 2.2. Remittances and other resource flows as a share of GDP to Pakistan

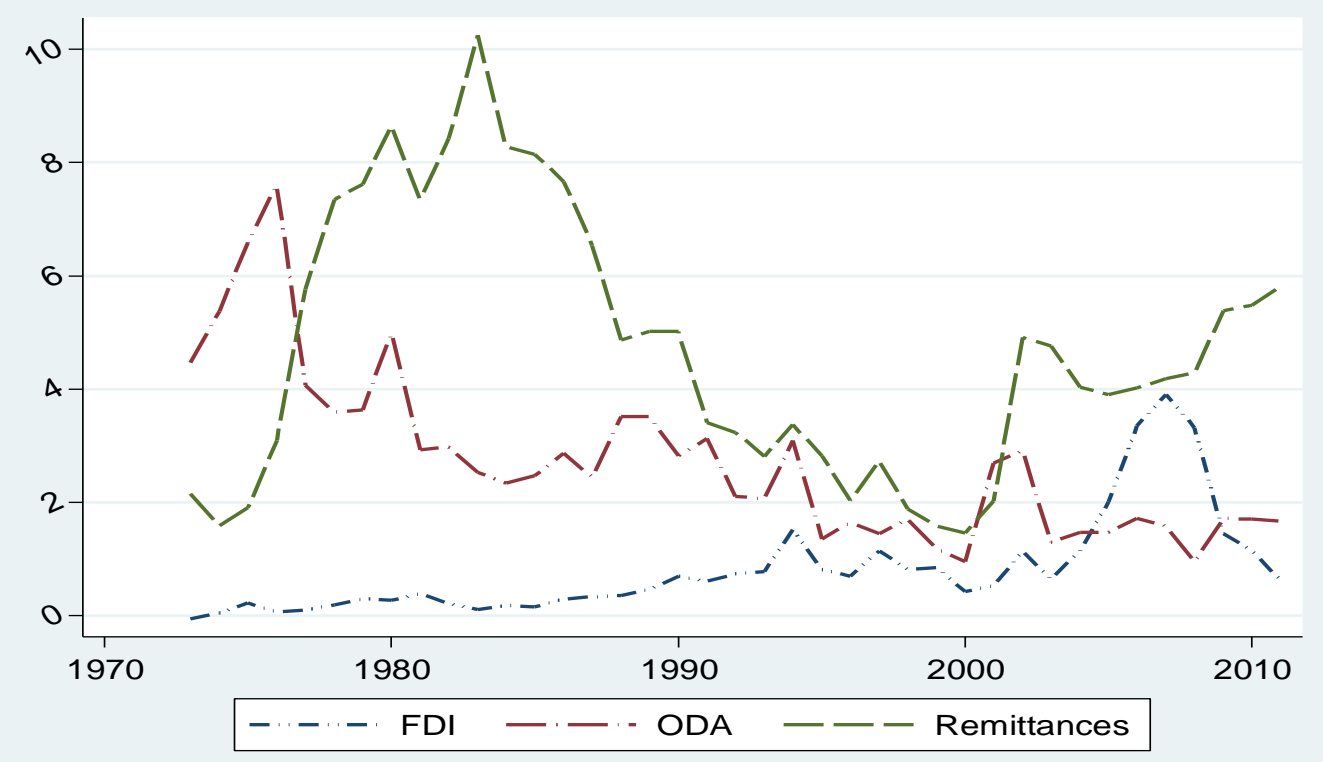

Source: calculation based on WDI and OECD (2013) 
The possible reasons for this spectacular rise in remittance flows over time include a reduction in the cost of remitting, the increasing availability of more convenient formal remittance services, a growing Pakistani diaspora ${ }^{3}$, the improving skill level of immigrants (Amjad et al., 2013), and the growing interest of Pakistani migrants' in the country development. The Middle East is the foremost source of remittances to Pakistan, followed by North America and Europe (Figure 2.3). The significant growth in remittance flows has proved a lifeline for the economy during times of economic hardship.

Figure 2.3.Top remittance sending regions (USD millions)

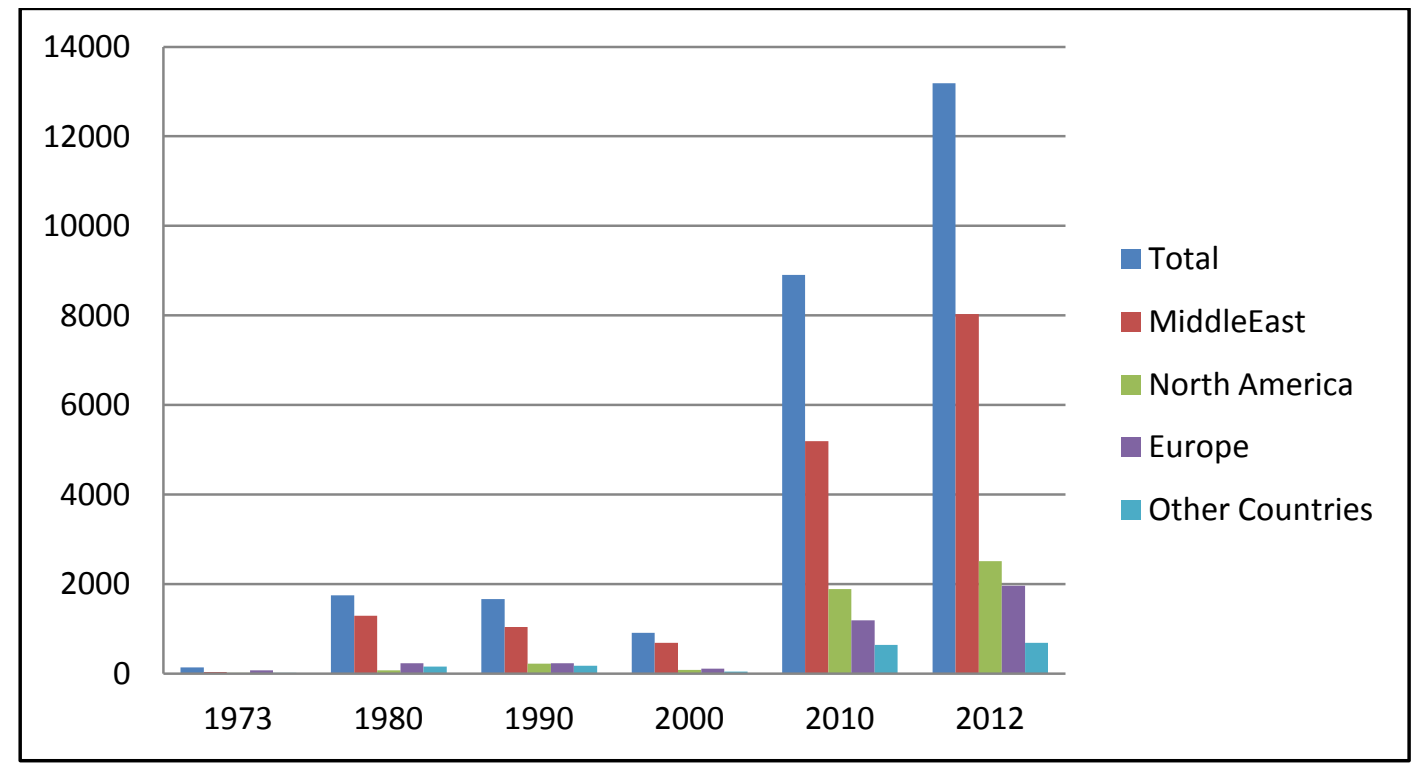

Source: State Bank of Pakistan

The share of FDI inflows to the economy was negligible before the 1990s, mainly due to the regulatory policy framework (Khan and Khan, 2011). After the launching of a liberalization program in 1992, FDI displayed remarkable progress (Khan, 1997). However, flows have fallen sharply recently as shown in Figure 2.1. For instance, in 2012, FDI to Pakistan fell by 35 percent from USD 1308 million in 2011 to USD 854 million (WDI, 2013), and it is likely to decrease further due to deteriorating security situation, chronic energy crisis, and ad-hoc and inconsistent government policies. This is despite the fact that Pakistan ranks above several other Asian

\footnotetext{
${ }^{3}$ An estimated 6.3 million Pakistanis live abroad. In regional terms about 3 and a half million Pakistanis migrated to the Middle East, 1.8 to Europe and 1.2 to the Americas, respectively (Bureau of Emigration and Overseas Employment, 2012). The main concentrations of Pakistani migrants are found in Saudi Arabia, United Arab Emirates, United Kingdom, United States and Canada, respectively.
} 
economies (placed $83^{\text {rd }}$ among 183 world economies) in terms of ease of doing business (IFC, 2011). Pakistan's major investors include the United States, the United Arab Emirates, China, Japan and the European Union. Banking and finance, telecommunications, oil and gas and retail sectors have attracted most of the recent FDI inflows to Pakistan (State Bank of Pakistan, 2012).

ODA is another form of capital inflows, which main aim is facilitating economic development in developing countries. It refers to grants, loans and technical and economic assistance send by developed to developing countries. Pakistan received USD 3509 million net ODA in 2011, which accounts for only about 1.7 percent of Pakistan's GDP (see Figure 2.1 Figure 2.2).

Given such low inflows of ODA, Pakistan is usually not considered an aid-dependent country (Malik, 2009). The foreign aid flows have fluctuated substantially depending on the changing circumstances in the international arena during previous decades. Flows remained high during the 1980s given the country's frontline state role in the US-Soviet conflict in Afghanistan (Malik et al, 1994). The flows decreased during the following decade, drying up in the aftermath of Pakistan's nuclear tests in 1998. After 2001, aid flows returned to the country, as Pakistan once again became a frontline state in the American-led war in Afghanistan (Aning, 2007). Top donors to the country over the years have been the USA, the International Development Association (IDA), the Asian Development Bank with special funds, the UK, Japan, EU institutions, Germany, the United Arab Emirates, Turkey and Australia (OECD, 2013).

\subsection{Financial Flows and Business Cycle: Review of the Empirical Literature}

In this section, we review the empirical literature that examines the relationship between financial flows and output fluctuations, placing special emphasis on remittances, but also covering ODA and FDI. Chami et.al (2009) suggests that remittances have a significant impact on smoothing macroeconomic fluctuations in recipient countries, concluding that remittances can be used as a stabilizing tool. They employ data for 70 different countries, including 16 advanced economies and 54 developing countries. Similarly, Giuliano and Ruiz-Arranz (2009) examine remittances and output cycles for a sample of approximately 100 developing countries over the period 19752002. They find that remittances are pro-cyclical for about two-thirds of the receiving countries. In the same fashion, Sayan (2006) studies the behavior of migrant remittance flows for 12 developing countries. Using a polynomial fitting model for the period 1976-2003, the study finds that while aggregate country data exhibit counter-cyclicality with respect to the GDP, individual 
countries show heterogeneous effects, as remittances can be pro-, counter-, or even a-cyclical. Lueth and Ruiz-Arranz (2008) reported that in the wake of a natural disaster, remittances appear to be aligned with the receiving-country's business cycle and may not play a major role in restraining vulnerability to shocks. The analysis is based on estimating a gravity model for migrants' remittances to a sample of developing countries. In contrast, Frankel (2011), using also bilateral remittances, suggests that migrants' remittances play a stabilizing role in the receiving countries. Vargas Silva (2008) revealed that remittances are counter-cyclical with respect to the Mexican business cycle, but the result was not robust to different definitions of remittances. However, strong coherence was found between the cyclical component of remittances and the US business cycle. In the context of South Asia, Lueth and Ruiz-Arranz (2007) determined that remittances in Sri Lanka are positively associated with the country's business cycle. In contrast, Ahmed (2012) argued that remittances to Pakistan are counter-cyclical with respect to the cyclical components of receiving output and consumption, whereas their behavior with respect to the cyclical components of sending countries output from the United States and the United Kingdom is a-cyclical. Indian remittances are likewise found to be a-cyclical with respect to sending economies (Mughal and Ahmed, 2014).

Foreign aid and FDI are similarly found to be pro-, counter- or a-cyclical depending on the country or set of countries studied and the time periods examined. For instance, using a sample of 33 countries over the period 1969-95, Pallage and Robe (2001) determined that in the majority of cases foreign aid has been pro-cyclical. Similarly, Bulir and Hamann (2003) showed that foreign aid is more volatile than domestic fiscal revenues and appeared to be pro-cyclical in the majority of countries. However, Chauvet and Guillaumont (2009) compared the cyclical behavior of aid over the period 1970-1999 using the trade cycle instead of the output cycle. They showed that foreign aid is more effective in countries that are vulnerable to exogenous shocks, because it mitigates its impact on growth. They assert that the main factor behind aid effectiveness for growth is the stabilizing nature of aid. In the same vein, comparing the cyclicality and stabilization impacts of migrant remittances with other major capital inflows, Neagu and Schiff (2009) find, using a sample of 116 developing countries over the period 1980-2007, that ODA flows are counter-cyclical while remittances tend to be pro-cyclical, but less so than FDI. Furthermore, they show that ODA is more stable than remittances and, in turn, remittances are more stable than FDI. 
In this study we take a similar approach to Neagu and Schiff (2009) and Vargas-Silva (2008). We extend their results by using data for a more recent period (1974-2011) and taking a closer look by focusing on a single country.

\subsection{Data and Methodology}

\subsubsection{Data Description}

In order to explore the stabilizing role of remittances and other financial flows to Pakistan, this study utilizes yearly data over the period 1974-2011. The main variables used in our study are remittances, FDI net inflows, ODA, and Gross Domestic Product (GDP) for Pakistan, while the output for sending economies for each of the four regions is calculated as the weighted sum of GDP for all the respective regions' constituent countries ${ }^{4}$. The data used are from the OECD (Organization of Economic Cooperation and Development), WDI (World Development Indicators, World Bank), UNCTAD (United Nations Conference on Trade and Development) and SBP (State Bank of Pakistan) databases. The data on remittances come from the WDI and State Bank of Pakistan. Remittances are current private transfers by migrants employed or intending to remain employed for more than one year in the remittances sending country in which they are considered residents. Therefore, remittances are recorded in the current account of the balance of payments. The data on FDI are taken from the WDI. FDI is defined as the sum of equity capital, reinvestment of earnings, other long-term capital and short-term capital as shown in the balance of payments. It reveals net inflows (new investment inflows minus disinvestment) from foreign investors. Finally, the net ODA data as a measure of foreign aid comes from the UNCTAD and OECD databases. ODA flows include grants and concessional loans - that is, loans that are at least $25 \%$ grants. We gather the GDP data for both receiving and sending countries from the WDI in constant 2000 US dollars. However, remittances, ODA and FDI data are initially in current USD and converted to constant 2000 USD using the GDP deflator. We take the logarithm of the variables before estimation.

Table 2.2 presents the descriptive statistics of key variables in real terms used in the analysis.

\footnotetext{
${ }^{4}$ We separated sending economies into four major geographic regions, namely North America (USA, Canada), Middle East (Saudi Arabia, United Arab Emirates, Kuwait, Qatar, Bahrain, Oman, Turkey), Europe (United Kingdom, Germany, France, Italy, Netherland, Spain, Greece, Belgium, Ireland, Switzerland, Sweden, Denmark, Norway), and Asia Pacific (Japan, Australia, Singapore, Hong Kong, Malaysia, New Zealand, China).
} 
Table 2.2. Descriptive statistics.

\begin{tabular}{lllll}
\hline & Mean & Maximum & Minimum & Standard deviation \\
\hline Remittances & 5426.24 & 14002.88 & 1075 & 3714.18 \\
\hline FDI & 806.89 & 3530.70 & 46.25 & 783.83 \\
\hline ODA & 3001.13 & 8455.64 & 702.69 & 1949.71 \\
\hline Pakistanis Output & 59635.94 & 118800 & 19411.12 & 29921.19 \\
\hline North American Output & $7.36 \mathrm{E}+08$ & $1.10 \mathrm{E}+09$ & $4.00 \mathrm{E}+08$ & $2.35 \mathrm{E}+08$ \\
\hline Middle East Output & 15725573 & 27967814 & 8423992 & 5585159 \\
\hline European Output & 99669866 & $1.32 \mathrm{E}+08$ & 65951596 & 21522452 \\
\hline Asia Pacific Output & $3.11 \mathrm{E}+08$ & $3.91 \mathrm{E}+08$ & $1.74 \mathrm{E}+08$ & 68345080 \\
& & & \\
\hline Number of observation $=38$ & & & \\
\hline Note: All series are in constant 2000 USD.
\end{tabular}

\subsubsection{Methodology}

The empirical methodology consists of four steps. Firstly, we use different types of filters to estimate the cyclical component of remittances, other financial flows and output of both Pakistan and the sending countries. Secondly, we estimate the co-movement between the cyclical components (including correlations using leads and lags). Thirdly, we check the stabilizing role of remittances in comparison with other financial inflows. Finally, we estimate impulse response functions and variance decompositions using a structural vector autoregressive (SVAR) model.

\subsubsection{Time Series Filtering}

In order to observe the cyclical behavior of time series, it is common practice to de-trend the series by employing filters. These filters eliminate the slowly-evolving (long-term trend) component and the rapidly-varying (irregular) component of a variable, leaving behind the intermediate-term or business-cycle component of the variable (Baxter and King, 1999). In this study, we use an inclusive approach to this problem by assuming that all filter procedures are approximations Canova (1998), which isolate different aspects of the trend and cyclical components of the series, separating the intermediate components. In order to isolate the cyclical components from the long-run trend, the Hodrick-Prescott (hereafter HP) is a high-pass filter, extracting only low frequencies and leaving all higher frequency fluctuations (Hodrick and Prescott, 1997). Two band-pass filters are also used that depart all frequencies above 8 years and below 1.5 years, namely the Baxter and King (hereafter BK) time domain-based filter (Baxter and King, 1999) and the Corbae and Ouliaris (hereafter CO) frequency domain filter (Corbae and Ouliaris, 2006). 
In this study, although we carry out estimations using the three above-mentioned filters, we mainly discuss the findings obtained using the $\mathrm{CO}$ filter, which overcomes some of the shortcomings of the other two filters (Corbae and Ouliaris, 2006).

\subsubsection{Main Features of Macroeconomic Fluctuations}

Following Kydland and Prescott (1990) and Pallage and Robe (2001), the degree of comovement between two stationary series $x_{t}$ and $y_{t}$ is measured by the magnitude of correlation coefficients $\rho(j), j \in\{0, \pm 1, \pm 2 \ldots .$.$\} . The cyclical component of x_{t}$ and $y_{t}$ is derived from using $\mathrm{HP}, \mathrm{BK}$ and CO filters. For instance, the degree of co-movement between the variables $x_{t}$ and $y_{t}$ is:
(a) Pro-cyclical if $\rho(j)>0$
(b) Counter-cyclical if $\rho(j)<0$ and
(c) A-cyclical if $\rho(j)=0$

Similarly, in order to observe significant correlation between two series, following Sayan and Tekin-Koru (2012), we consider the variable $x_{t}$ to be pro-cyclical (counter-cyclical) with $y_{t}$ if $0.32 \leq|\rho(0)|<1^{5}$. Moreover, we also check the timing of the most significant correlation coefficient to decide the dynamics of the relationship between a variable $x_{t}$ and $y_{t}$. The purpose is to ascertain whether there are possible phase shifts by looking at how early and how late the highest correlation appears relative to the contemporaneous period (Pallage and Robe, 2001). For instance, we say that series $x_{t}$ leads the cycle by $\mathrm{j}$ periods if significant $|\rho(j)|$ peaks at $x_{t-j}$ with $j>0$, the series $x_{t}$ coincides with the cycle if $|\rho(j)|$ peaks for $j=0$ and that the series $x_{t}$ lags the cycle by $\mathrm{j}$ periods if significant $|\rho(j)|$ peaks at $x_{t+j}$ with $j>0$. Finally if all correlations are trivial, then we can conclude that the association between the variables is acyclical.

\footnotetext{
${ }^{5}$ In this study, when the correlation coefficients fall outside the [-0.32, 0.32] range the null hypothesis is rejected, that is, the correlation is considered statistically significant. Details of how the minimum value 0.32 has been calculated are available in Appendix A2.1.
} 
Although single cross-correlations are useful to infer the strength of the relationship between pair of variables, they do not give information regarding causality with other variables. In order to address this limitation a Structural Vector Autoregression (SVAR) model is estimated in the next section.

\subsubsection{SVAR Model Specification and Restriction Identification}

We specify an SVAR model composed of a system of five equations including sending countries output i.e. (Middle Eastern, North American, European and Asia Pacific output), receiving country output, remittances, ODA and FDI. Furthermore, applying SVAR addresses the potential problem of endogeneity among variables. For instance, it is possible for remittances to impact the receiving-country business cycle, but it could also be that remittances respond to changes in the receiving-country business cycle.

Structural VAR is widely used in the empirical literature to identify the effects of endogenous disturbances within a system. The aim of a structural VAR is to use economic theory, rather than a Cholesky decomposition, to recover structural innovations from residuals of a reduced-form VAR. A SVAR is an n-equation, n-variable linear model in which each variable in turn is explained by its own lagged values, current and past values of the remaining n-1 variables. According to Sims (1980), variables should be treated on equal footing if there is simultaneity among a set of variables. Consequently, there is not an a priori distinction between endogenous and exogenous variables (Gujarati, 2004 p.848). Before estimating the SVAR model, the optimum number of lags has to be selected. This is an important issue since adding too many lagged terms can lead to insufficient degrees of freedom, whereas adding too few can lead to specification errors ${ }^{6}$. SVAR models also require identifying assumptions ${ }^{7}$. A variety of SVAR models have been proposed in the literature that support short-term constraints (Sims, 1986; Bernanke, 1986; Blanchard and Watson, 1986), long-term restrictions (Blanchard and Quah, 1989), or groups of both short-term and long-term restrictions (Gali, 1992) on impulse response derived from the underline economic theory. The main objective of an SVAR estimation is to

6 The decision of the appropriate lag length is made using the Akaike, Schwarz and Hannan-Quinn and Final Prediction Error criteria.

7 The "identification problem" calls for imposing restrictions on some of the structural parameters. Identification by means of the Cholesky decomposition is considered a mechanical technique that some deem unrelated to economic theory. 
obtain non-recursive orthogonalization of the error terms for the impulse response analysis. This alternative to the recursive Cholesky orthogonalization requires that sufficient restrictions are imposed to identify the orthogonal (structural) components of the error terms.

The structural model to be implemented in this study is described by the following dynamic system of simultaneous equations (2.1 to 2.5$)$.

$$
\begin{aligned}
& Y_{t}^{s}=b_{10}-a_{12} Y_{t}^{r}-a_{13} X_{t}^{r e m}-a_{14} X_{t}^{o d a}-a_{15} X_{t}^{f d i}+\sum_{i=1}^{p} b_{11}^{i} Y_{t-p}^{s}+\sum_{i=1}^{p} b_{12}^{i} Y_{t-p}^{r}+ \\
& \sum_{i=1}^{p} b_{13}^{i} X_{t-p}^{r e m}+\sum_{i=1}^{p} b_{14}^{i} X_{t-p}^{o d a}+\sum_{i=1}^{p} b_{15}^{i} X_{t-p}^{f d i}+\varepsilon_{t}^{s} \\
& Y_{t}^{r}=b_{20}-a_{21} Y_{t}^{s}-a_{23} X_{t}^{r e m}-a_{24} X_{t}^{o d a}-a_{25} X_{t}^{f d i}+\sum_{i=1}^{p} b_{21}^{i} Y_{t-p}^{s}+\sum_{i=1}^{p} b_{22}^{i} Y_{t-p}^{r}+ \\
& \sum_{i=1}^{p} b_{23}^{i} X_{t-p}^{r e m}+\sum_{i=1}^{p} b_{24}^{i} X_{t-p}^{o d a}+\sum_{i=1}^{p} b_{25}^{i} X_{t-p}^{f d i}+\varepsilon_{t}^{r} \\
& X_{t}^{r e m}=b_{30}-a_{31} Y_{t}^{s}-a_{32} Y_{t}^{r}-a_{34} X_{t}^{o d a}-a_{35} X_{t}^{f d i}+\sum_{i=1}^{p} b_{31}^{i} Y_{t-p}^{s}+\sum_{i=1}^{p} b_{32}^{i} Y_{t-p}^{r}+ \\
& \sum_{i=1}^{p} b_{33}^{i} X_{t-p}^{r e m}+\sum_{i=1}^{p} b_{34}^{i} X_{t-p}^{o d a}+\sum_{i=1}^{p} b_{35}^{i} X_{t-p}^{f d i}+\varepsilon_{t}^{r e m} \\
& X_{t}^{o d a}=b_{40}-a_{41} Y_{t}^{s}-a_{42} Y_{t}^{r}-a_{43} X_{t}^{r e m}-a_{45} X_{t}^{f d i}+\sum_{i=1}^{p} b_{41}^{i} Y_{t-p}^{s}+\sum_{i=1}^{p} b_{42}^{i} Y_{t-p}^{r}+ \\
& \sum_{i=1}^{p} b_{43}^{i} X_{t-p}^{r e m}+\sum_{i=1}^{p} b_{44}^{i} X_{t-p}^{o d a}+\sum_{i=1}^{p} b_{45}^{i} X_{t-p}^{f d i}+\varepsilon_{t}^{o d a} \\
& X_{t}^{f d i}=b_{50}-a_{51} Y_{t}^{s}-a_{52} Y_{t}^{r}-a_{53} X_{t}^{r e m}-a_{54} X_{t}^{o d a}+\sum_{i=1}^{p} b_{51}^{i} Y_{t-p}^{s}+\sum_{i=1}^{p} b_{52}^{i} Y_{t-p}^{r}+ \\
& \sum_{i=1}^{p} b_{53}^{i} X_{t-p}^{r e m}+\sum_{i=1}^{p} b_{54}^{i} X_{t-p}^{o d a}+\sum_{i=1}^{p} b_{55}^{i} X_{t-p}^{f d i}+\varepsilon_{t}^{f d i}
\end{aligned}
$$

where:

$\varepsilon_{t}^{S}, \varepsilon_{t}^{r}, \varepsilon_{t}^{r e m}, \varepsilon_{t}^{o d a}$ and $\varepsilon_{t}^{f d i} \sim i . i . d\left(0, \sigma_{\varepsilon i}^{2}\right)$ and $\operatorname{cov}\left(\varepsilon_{t}^{s}, \varepsilon_{t}^{r}, \varepsilon_{t}^{r e m}, \varepsilon_{t}^{o d a}, \varepsilon_{t}^{f d i}\right)=0$

sending countries output ( $\left.Y_{t}^{s}\right)$, receiving output $\left(Y_{t}^{r}\right)$, remittances $\left(X_{t}^{\text {rem }}\right)$, ODA $\left(X_{t}^{\text {oda }}\right)$ and foreign direct investment $\left(X_{t}^{f d i}\right)$ are endogenous variables and assumed to be stationary. Here the exogenous error terms $\varepsilon_{t}^{s}, \varepsilon_{t}^{r}, \varepsilon_{t}^{r e m}, \varepsilon_{t}^{o d a}$ and $\varepsilon_{t}^{\text {fdi }}$ are independent and denoted as structural innovations.

Using matrix algebra, we can write the system (eq. 2.1 to 2.5 ) in matrix notation, 


$$
\left[\begin{array}{ccccc}
1 & a_{12} & a_{13} & a_{14} & a_{15} \\
a_{21} & 1 & a_{23} & a_{24} & a_{25} \\
a_{31} & a_{32} & 1 & a_{34} & a_{35} \\
a_{41} & a_{42} & a_{43} & 1 & a_{45} \\
a_{51} & a_{52} & a_{53} & a_{54} & 1
\end{array}\right]\left[\begin{array}{c}
Y_{t}^{s} \\
Y_{t}^{r} \\
X_{t}^{r e m} \\
X_{t}^{o d a} \\
X_{t}^{f d i}
\end{array}\right]=\left[\begin{array}{c}
b_{10} \\
b_{20} \\
b_{30} \\
b_{40} \\
b_{50}
\end{array}\right]+\left[\begin{array}{lllll}
b_{11} & b_{12} & b_{13} & b_{14} & b_{15} \\
b_{21} & b_{22} & b_{23} & b_{24} & b_{25} \\
b_{31} & b_{32} & b_{33} & b_{34} & b_{35} \\
b_{41} & b_{42} & b_{43} & b_{44} & b_{45} \\
b_{51} & b_{52} & b_{53} & b_{54} & b_{55}
\end{array}\right]\left[\begin{array}{c}
Y_{t-i}^{s} \\
Y_{t-i}^{r} \\
X_{t-i}^{r e m} \\
X_{t-i}^{o d a} \\
X_{t-i}^{f d i}
\end{array}\right]+\left[\begin{array}{c}
\varepsilon_{t}^{s} \\
\varepsilon_{t}^{r} \\
\varepsilon_{t}^{r e m} \\
\varepsilon_{t}^{o d a} \\
\varepsilon_{t}^{f d i}
\end{array}\right]
$$

Where $\mathrm{i}=1,2,3, \ldots, \mathrm{n}$

In simple terms, it can be expressed as,

$A Z_{t}=B_{0}+B_{1} Z_{t-i}+\varepsilon_{t}$

Where $Z_{t}$ is the (n $x 1$ ) vector of the endogenous variables and $Z_{t-i}$ is the (n $x \mathrm{n}$ ) matrix that contains the lagged endogenous variables, while $\Sigma_{\varepsilon}=E\left(\varepsilon \varepsilon^{\prime}\right)$ yields the variance-covariance matrix of the structural innovations.

Pre-multiplying with $A^{-1}$, we obtained the corresponding reduced form (VAR) ${ }^{8}$ in the context of SVAR given by Equation (2.7), as we cannot use OLS to estimate an SVAR, due to contemporaneous effects correlated with the structural shocks $\left(\varepsilon_{t}\right)$.

$A^{-1} A Z_{t}=A^{-1} B_{0}+A^{-1} B_{1} Z_{t-1}+A^{-1} \varepsilon_{t}$

Thus,

$$
Z_{t}=A^{-1} B_{0}+A^{-1} B_{1} Z_{t-1}+A^{-1} \varepsilon_{t}
$$

In other words the reduced form model given in eq. (2.7) is equal to

$$
Z_{t}=C_{0}+C_{1} Z_{t-i}+e_{t}
$$

Where, $A^{-1} B_{0}=C_{0}, A^{-1} B_{1}=C_{1}$ and $A^{-1} \varepsilon_{t}=e_{t}$, the variance-covariance of the reduced form is given by $\Sigma_{e}=E\left(e e^{\prime}\right)$

Equation (2.9) can be written in matrix form as:

\footnotetext{
${ }^{8}$ The main problem in estimating the structural model is that one cannot directly estimate the variables of interest, such as $A$ and $B_{1}$ in Equation (2.7).
} 


$$
\left[\begin{array}{c}
Y_{t}^{s} \\
Y_{t}^{r} \\
X_{t}^{r e m} \\
X_{t}^{o d a} \\
X_{t}^{f d i}
\end{array}\right]=\left[\begin{array}{c}
c_{10} \\
c_{20} \\
c_{30} \\
c_{40} \\
c_{50}
\end{array}\right]+\left[\begin{array}{lllll}
c_{11} & c_{12} & c_{13} & c_{14} & c_{15} \\
c_{21} & c_{22} & c_{23} & c_{24} & c_{25} \\
c_{31} & c_{32} & c_{33} & c_{34} & c_{35} \\
c_{41} & c_{42} & c_{43} & c_{44} & c_{45} \\
c_{51} & c_{52} & c_{53} & c_{54} & c_{55}
\end{array}\right]\left[\begin{array}{c}
Y_{t-i}^{s} \\
Y_{t-i}^{r} \\
X_{t-i}^{r e m} \\
X_{t-i}^{o d a} \\
X_{t-i}^{f d i}
\end{array}\right]+\left[\begin{array}{c}
e_{t}^{s} \\
e_{t}^{r} \\
e_{t}^{r e m} \\
e_{t}^{\text {oda }} \\
e_{t}^{f d i}
\end{array}\right]
$$

Equations (2.9) and (2.10) represent a standard reduced form VAR, which can be estimated with OLS. The predetermined variables are in the right hand side of the equation, while the error terms are white noise. The errors are serially uncorrelated, but correlated across equations.

Let us recall equation (2.9), in which the structural model relates the regression residuals and the pure innovations in the following way:

$\varepsilon_{t} A^{-1}=e_{t}$

We model the contemporaneous relationships among the variables as suggested by Vargas Silva (2008) with some modifications as:

$y^{s}=\varepsilon^{s}$

$y^{r}=a_{21} y^{s}+a_{23} x^{r e m}+a_{24} x^{o d a}+a_{25} x^{f d i}+\varepsilon^{r}$

$x^{r e m}=a_{31} y^{s}+a_{32} y^{r}+\varepsilon^{r e m}$

$x^{\text {oda }}=a_{41} y^{r}+\varepsilon^{o d a}$

$x^{f d i}=a_{51} y^{s}+a_{52} y^{r}+\varepsilon^{f d i}$

where $\mathrm{y}^{\mathrm{s}}, y^{r}, x^{r e m}, x^{o d a}, x^{f d i}$ are the regression residuals obtained from the reduced form VAR, and $\varepsilon^{\mathrm{s}}, \varepsilon^{r}, \varepsilon^{r e m}, \varepsilon^{o d a}, \varepsilon^{f d i}$ are the pure shocks (i.e., structural innovations) to the detrended series in terms of $\log ,\left(Y^{s}\right)\left(Y^{r}\right),\left(X^{r e m}\right),\left(X^{o d a}\right)$ and $\left(X^{f d i}\right)$ respectively. Hence, the model specified above in reduced form provides the number of assumptions necessary to identify the SVAR model. The assumptions imply that changes in the sending-country output are assumed to be only affected by its own shocks, meaning that sending-country output is not promptly affected by other variables in the model. Receiving-country output is in turn affected by shocks to sendingcountry output, remittances, ODA and FDI. Remittances are influenced by both output shocks. This is consistent with the evidence that changes in the economic conditions of receiving 
countries are significant in explaining remittance behavior (Kock and Sun, 2011). Similarly, FDI is also influenced by both output shocks. However, ODA is only affected by innovation to sending-country output. The above specification is appealing, as it does not impose any restrictions on the long-run behavior of economic variables.

\subsection{Main Results}

Subsection 2.5.1 presents the volatility of the analyzed flows derived from the filtered series and the corresponding correlation. The stabilizing nature of remittances, ODA and FDI with respect to output are also reported in this section. The SVAR estimations are discussed in section 2.5.2.

\subsubsection{Volatility, Cyclicality and Stabilization of Financial Flows}

Figure 2.4 reports the volatility of each capital inflow over the period 1974-2011 based on the standard deviation of the cyclical ratio of the corresponding variable to GDP. According to our calculations, FDI is 163 percent and ODA is 27 percent more volatile than remittances during the sample period 1974-2011. These findings revealed that remittances to Pakistan are a relatively stable source of external finance, compared with ODA and FDI inflows.

Figure 2.4. Volatility of Financial Inflows to Pakistan, 1974-2011

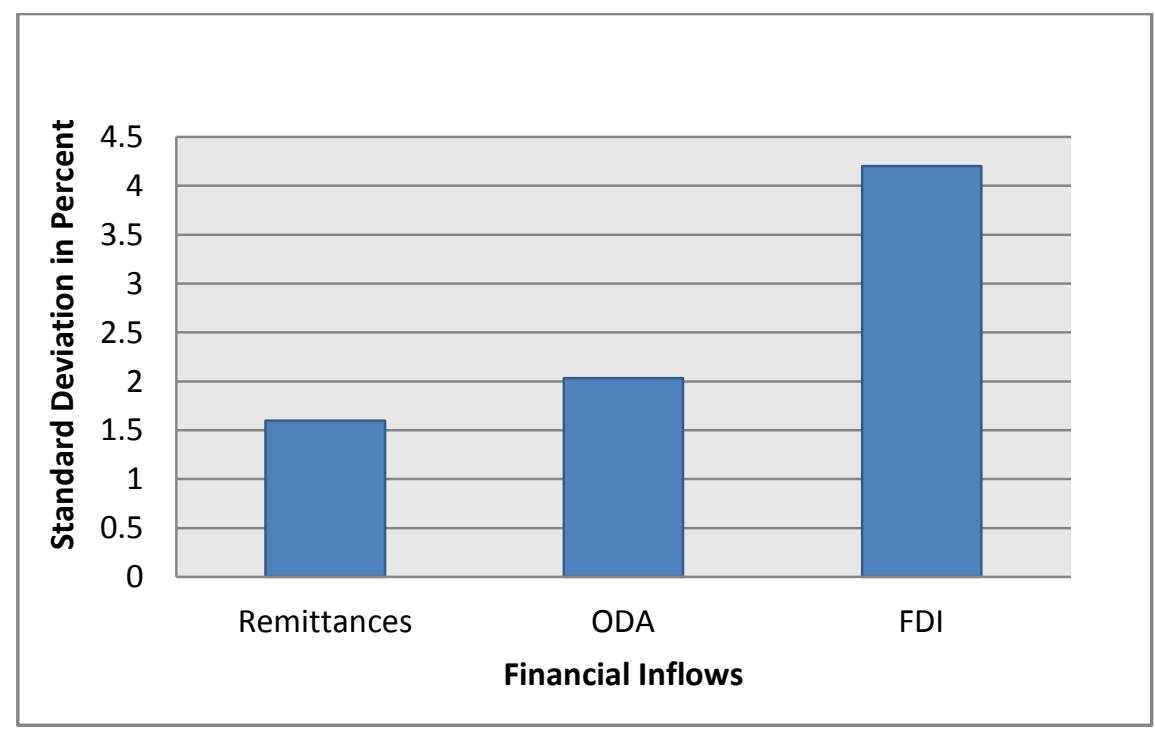

Note: Volatility is defined as the percentage standard deviation of the detrended ratio of the relevant inflows to GDP. The CO filter has been used to extract detrended series.

The figures showing the greater resilience of remittances in comparison with FDI and ODA corroborate the findings of Buch and Kuckulenz (2010) and Mughal and Makhlouf (2011). 
Next, we look at the cross-correlation between the cyclical components of the financial flows and the corresponding annual GDP for receiving and sending economies. As discussed earlier, HP, $\mathrm{BK}$ and $\mathrm{CO}$ filters are used to extract the cyclical components of a series 9 . Following Burns and Mitchel (1946), Business-cycle frequency is defined to be between 2 and 8 years in estimating the cyclical components using BK-filtered (time domain) and CO-filtered (frequency domain) techniques. For BK filter, components of the time series with period fluctuation between 2 and 8 year are retained, while the components at higher and lower frequencies could be removed. Similarly, in the Corbae-Ouliaris filter we specify the minimum and maximum period of oscillation to be retained in the series. The common value of 2 and 8 year (frequencies $1 / 4$ and 1) are used in this study. The Baxter and King (1999) produce about similar results as Corbae and Ouliaris (2006) though without the end point problem. Meanwhile, the HP Filter is applied to the trend-cycle component of each variable, in order to extract the stationary (cyclical) and nonstationary (trend) components. In this case, we do so following the business cycle definition by Lucas (1977) and Kydland and Prescott (1990), stated as deviations of aggregate real output from its long-run trend (a growth cycle). For the HP filter, the smoothing parameter (lambda) value of 6.25 corresponds to a value of 1600 for quarterly data (Ravn and Uhlig, 2002). In a next step we compute correlation coefficients between the detrended real output of both sending and receiving countries and the lead, current and lag of detrended remittances, ODA and FDI. The maximum number of leads and lags is fixed to two in each case ${ }^{10}$. The results of contemporaneous crosscorrelation as well as asynchronous correlation are presented in Table 2.3.

First, we look at the correlations between the cyclical components of financial flows and Pakistani GDP during the period 1974- 2011. The negative association and statistical significance of the contemporaneous correlation coefficient reported in Table 2.3 implies that remittances sent to Pakistan tend to move counter-cyclically relative to receiving output, regardless of which filter is used $^{11}$. This implies that remittances provide relief to low income families, mainly in times of economic hardship. The results corroborate the findings of Anwar and Mughal (2012) that remittances to Pakistan are sent mainly for altruistic motives. Remittances therefore perform a welcome stabilization function during times of economic recession. Quite the reverse, the

\footnotetext{
9 Other filters method were also employed but are not used for estimations given their inferior performance as compared to OC filter.

${ }^{10}$. Leads and lags have been selected arbitrarily. Use of different leads and lags does not alter the essence of our estimation.

${ }^{11}$ Results of both HP and BK filters are available upon request
} 
association between FDI and receiving output appears to be positive and significant, implying that FDI tends to act pro-cyclically and synchronous to the country's business cycle. Similarly, the pro-cyclical nature of FDI depicts that more is to be gained by a foreign investor when the receiving economy performs better. This explains the fall in FDI flows over the last five years, as the country is suffering from deteriorating security situation and chronic energy crisis.

On the other hand, ODA turned out to be a-cyclical, implying a-cyclical behavior with respect to Pakistani output. The results are not surprising as finalizing aid budgets, commitment and disbursement procedures might be too sluggish to readily react to the ups and downs of economic activity at receiving-country output level. Overall, both ODA and FDI do not seem to play a major role in limiting the vulnerability to macroeconomic shocks in the receiving country.

Table 2.3. Summary of Cross Correlations between Sending-Country and Pakistani Output at Time $t$ and Financial Inflows (Remittances, FDI and ODA).

\begin{tabular}{|c|c|c|c|c|c|c|}
\hline \multirow[t]{2}{*}{ Variables } & & \multicolumn{2}{|c|}{ Remittances } & \multirow{2}{*}{$\frac{\text { ODA }}{\text { Cyclicality }}$} & \multicolumn{2}{|l|}{ FDI } \\
\hline & & Cyclicality & Lead/Lag & & Cyclicality & Lead/Lag \\
\hline $\begin{array}{l}\text { Recipients } \\
\text { Economy }\end{array}$ & Pakistanis Output & $\begin{array}{l}\text { Counter- } \\
\text { cyclical }\end{array}$ & Coincident & A-cyclical & Pro-cyclical & Coincident \\
\hline \multirow{4}{*}{. } & $\begin{array}{l}\text { Middle East } \\
\text { Output }\end{array}$ & $\begin{array}{l}\text { Counter- } \\
\text { cyclical }\end{array}$ & Lagging & A-cyclical & A-cyclical & - \\
\hline & $\begin{array}{l}\text { North American } \\
\text { Output }\end{array}$ & A-cyclical & & A-cyclical & Pro-cyclical & Lagging \\
\hline & European Output & A-cyclical & 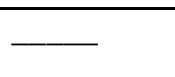 & A-cyclical & Pro-cyclical & Lagging \\
\hline & $\begin{array}{l}\text { Asia Pacific } \\
\text { Output }\end{array}$ & A-cyclical & 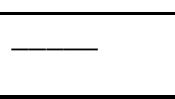 & A-cyclical & Pro-cyclical & Coincident \\
\hline
\end{tabular}

Note: $t=1974, \ldots, 2011$.

Table 2.3 shows the contemporaneous and asynchronous (up to two years) cross correlation of remittances and major sending countries' business activity. In this case, remittance flows depend on the economic conditions of the sending economies. For instance, if incomes rise in the sending economy, Pakistani migrants may send more money back home, so the boom in the sending country is transmitted to Pakistan through remittances.

Remittances to Pakistan and the business cycle activity of the Middle East appeared to be negatively correlated, that is moving counter-cyclically and peaking one year after a shock to the Middle East output. This finding warrants some discussion. In the 1970s and 1980s, Pakistan 
supplied a large proportion of the labor requirements of countries in the Middle East. Official remittances to Pakistan during that period accounted for as much as 10 percent of GDP and as a result were hit the hardest by the 1990-1991 Gulf war and the ensuing financial difficulties that the countries in the region faced. Thousands of temporary Pakistani migrants returned home, bringing all their savings with them. This reflects in the negative correlation between remittance flows to Pakistan and Middle East output. Another explanation may be that during the current economic slump, remittances to Pakistan from the Middle East have not suffered, but in fact kept on increasing, again indicating a negative correlation. In a similar fashion, it is important to ascertain how other external factors, such as economic growth in the region, have influenced FDI and ODA flows to Pakistan. We find a-cyclical behavior between FDI (ODA) and Middle East output, regardless of which filter is used. This implies that investors' decisions to invest in Pakistan as well as donors' preferences for ODA are not primarily based on the country business cycle.

However, as shown in Table 2.3, we fail to find any association between the cyclical components of remittances and economic activity in North America, Europe or the Asian pacific region. Therefore, remittances show a-cyclical patterns for major sending-countries. Similarly, correlation estimation suggests that ODA inflows are unaltered by sending-countries' economic cycles.

In contrast, FDI to Pakistan is typically pro-cyclical in regard to regional output. Our findings show that outward FDI from these countries contract when conditions in investor countries are unfavorable. The finding shows that remittances to Pakistan remain a-cyclical regardless of fluctuations in most of the sending countries, particularly due to the diverse nature of migrant outflows from Pakistan to different regions around the globe.

An alternative way to examine the stabilization impact of financial flows that goes beyond cyclicality was suggested by Chauvet and Guillaumont (2009) and Neagu and Schiff (2009).

The authors propose a stabilization index that is given by

$$
S I_{X}=\text { volatility of } Y-\text { volatility of }(X+Y)
$$


Where SI denotes stabilization index, $\mathrm{X}$ represents the financial flows to the country (Remittances, ODA or FDI) and Y corresponds to receiving country GDP. Volatility is measured with the coefficient of variation $(\mathrm{CV})$, hence

$S I_{X}=C V(Y)-C V(X+Y)>0 \quad$ Stabilizing

$S I_{X}=C V(Y)-C V(X+Y)<0 \quad$ Destabilizing

When this difference is positive (negative), the variable $\mathrm{X}$ has a stabilizing (destabilizing) nature with respect to country output.

There are two interesting results in Table 2.4 that deserve some discussion. Sayan (2006) mentioned that remittances could be used to help steady the recipient economy during the recession phase of a business cycle. However, pro-cyclical remittances may act as a destabilizing force by inducing additional fluctuations in output. The cyclicality assumption is not enough to conclude whether remittances flows are stabilizing or destabilizing the economy (Chauvet and Guillaumont, 2009). They argued that the stabilization character of financial inflows does not only depend on their cyclicality, but also on their relative volatility with respect to exports ${ }^{12}$.

Table 2.4. Stabilizing or destabilizing impact of financial flows with regard to output when they are pro or counter-cyclical

\begin{tabular}{lcc}
\hline & Pro-cyclical & Counter-cyclical \\
\hline Stabilizing & Cross Corr. Coeff. $\geq 0.32$ & Cross Corr. Coeff. $\leq-0.32$ \\
& Stabilization Index $>0$ & Stabilization Index $>0$ \\
\hline Destabilizing & Cross Corr. Coeff. $\geq 0.32$ & Cross Corr. Coeff. $\leq \mathbf{- 0 . 3 2}$ \\
& Stabilization Index $<0$ & Stabilization Index $<0$ \\
\hline
\end{tabular}

Pro-cyclical remittances may be stabilizing if its volatility is lower than that of output. On the contrary, remittances could be counter-cyclical and stabilizing only when its volatility does not go beyond a certain thresholds. This means that the steadiness of remittances can be an important stabilization tool even if they are not counter-cyclical or mildly pro-cyclical for the recipient economy.

Table 2.5 reports the stabilizing nature of remittances, FDI or ODA, which helps decrease the variability of GDP measured by the coefficient of variation.

\footnotetext{
${ }^{12}$ We compute stabilization nature of financial inflows with regards to recipients' output.
} 
Table 2.5. Stabilizing nature of remittances, ODA and FDI with respect to Output.

\begin{tabular}{llll}
\hline Variable & Standard deviation & Mean & $\begin{array}{l}\text { Coefficients of } \\
\text { Variation }\end{array}$ \\
\hline Remittances & 0.706 & 8.367 & 8.43 \\
\hline ODA & 0.678 & 7.793 & 8.70 \\
\hline FDI & 0.936 & 6.310 & 14.8 \\
\hline GDP & 0.548 & 10.86 & 5.04 \\
\hline Remittances + GDP & 0.681 & 19.23 & 3.54 \\
\hline ODA + GDP & 0.318 & 18.65 & 1.70 \\
\hline FDI + GDP & 1.400 & 17.17 & 8.16 \\
\hline Note: CV= Coefficient of variation, computed as (standard deviation/mean) $* 100$ & \\
SI $_{\text {Remittances }=1.5}$ & & \\
$\mathrm{SI}_{\mathrm{ODA}}=3.3$ & & \\
$\mathrm{SI}_{\mathrm{FDI}}=-3.1$ & &
\end{tabular}

The results indicate that both remittance and ODA inflows appear to exert a stabilizing influence, but the opposite is true in case of FDI, which emerges as destabilizing. This finding reflects that the relative stability of remittances may provide further assistance to the economy in terms of reduced volatility of receiving-country output.

\subsubsection{Empirical Evidence from a SVAR}

As a preliminary step, we investigate the time series properties of the data by testing for the presence of unit roots. The results of the Augmented Dickey Fuller test ${ }^{13}$ show that all variables are non-stationary in levels but stationary in first differences. Next, we use impulse response functions commonly used in SVAR analysis in order to examine the responses of the variables to exogenous shocks. An optimal lag length of two is chosen based on different information criteria in order to obtain reasonable dynamics. Two lags were sufficient to remove any serial correlation to satisfy the normality and stability tests, without losing too many degrees of freedom. We then

\footnotetext{
${ }^{13}$ The ADF tests the null hypothesis that a time series is $I(1)$ against the alternative hypothesis that it is $I(0)$. The ADF here consists of estimating the following regression:

$$
\Delta Y_{t}=\beta_{1}+\beta_{2} t+\delta Y_{t-1}+\alpha_{i} \sum_{i=1}^{m} \Delta Y_{t-i}+\varepsilon_{t}
$$

If the null hypothesis is rejected, it means that the variable is stationary, whereas acceptance of the null hypothesis means the series is non-stationary at that level and needs to be differenced to make it stationary. Test results are reported in the Appendix Table A2.7.
} 
utilize impulse response functions to examine the dynamic causal relationship between remittances, FDI, ODA and sending- and receiving-country output. The plot of impulse responses presented in Figure 2.5 reveal the dynamic effects of remittances, ODA and FDI to Pakistan and Middle East output shocks. The impulse response of remittances to Pakistan to one standard deviation shock to Middle East output is negative and significant after one year. This is in line with the significantly negative correlation found for remittances to Pakistan. In contrast, the impulse response of inward FDI and ODA is insignificant in the case of Middle East output.

Figure 2.5. Response of Remittances, ODA and FDI to Shocks to Middle East and Pakistani Output

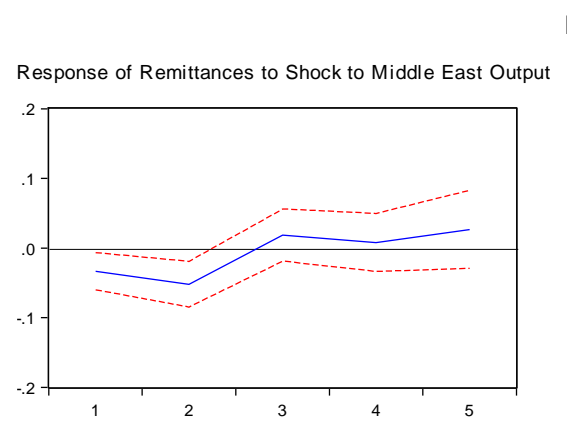

Response to StructuralOne S.D. Innovations \pm 2 S.E.

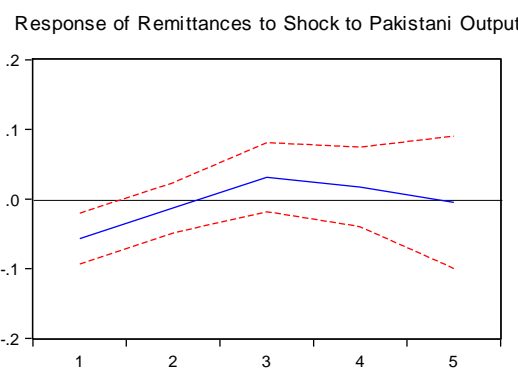

Response of ODA to Shock to Middle East Output

Response of ODA to Shock to Pakistani Output
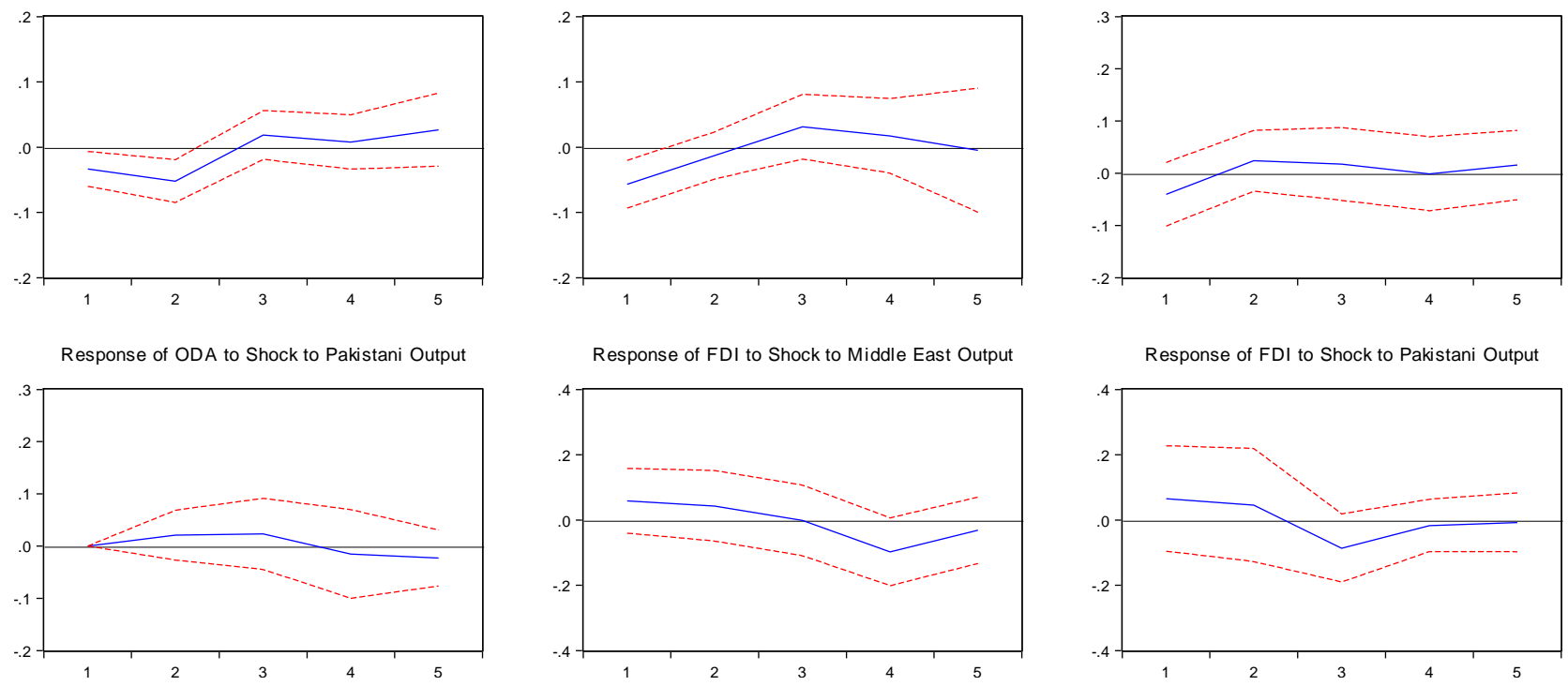

Response of FDI to Shock to Pakistani Output

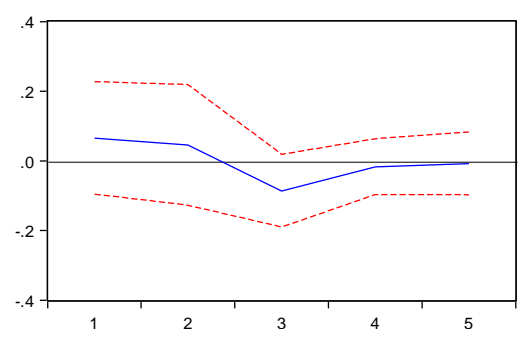

Similarly, the response of remittances to Pakistani output is negative and significant describing a counter-cyclical mechanism for these flows, which would rise when the receiving country is growing below its potential level of income. However, the response of ODA is mildly procyclical, that is, it increases once economic conditions improve in the recipient economy. Meanwhile, no significant association is found between FDI and receiving-country output. Figure 2.6 presents impulse responses to a shock in North American output and responses of financial flows. ODA to the country responds counter-cyclically after a shock to North American output, while FDI responds positively and significantly after two periods to an initial shock to North American output. 
Figure 2.6. Response of Remittances, ODA and FDI to Shocks to North American and Pakistani Output

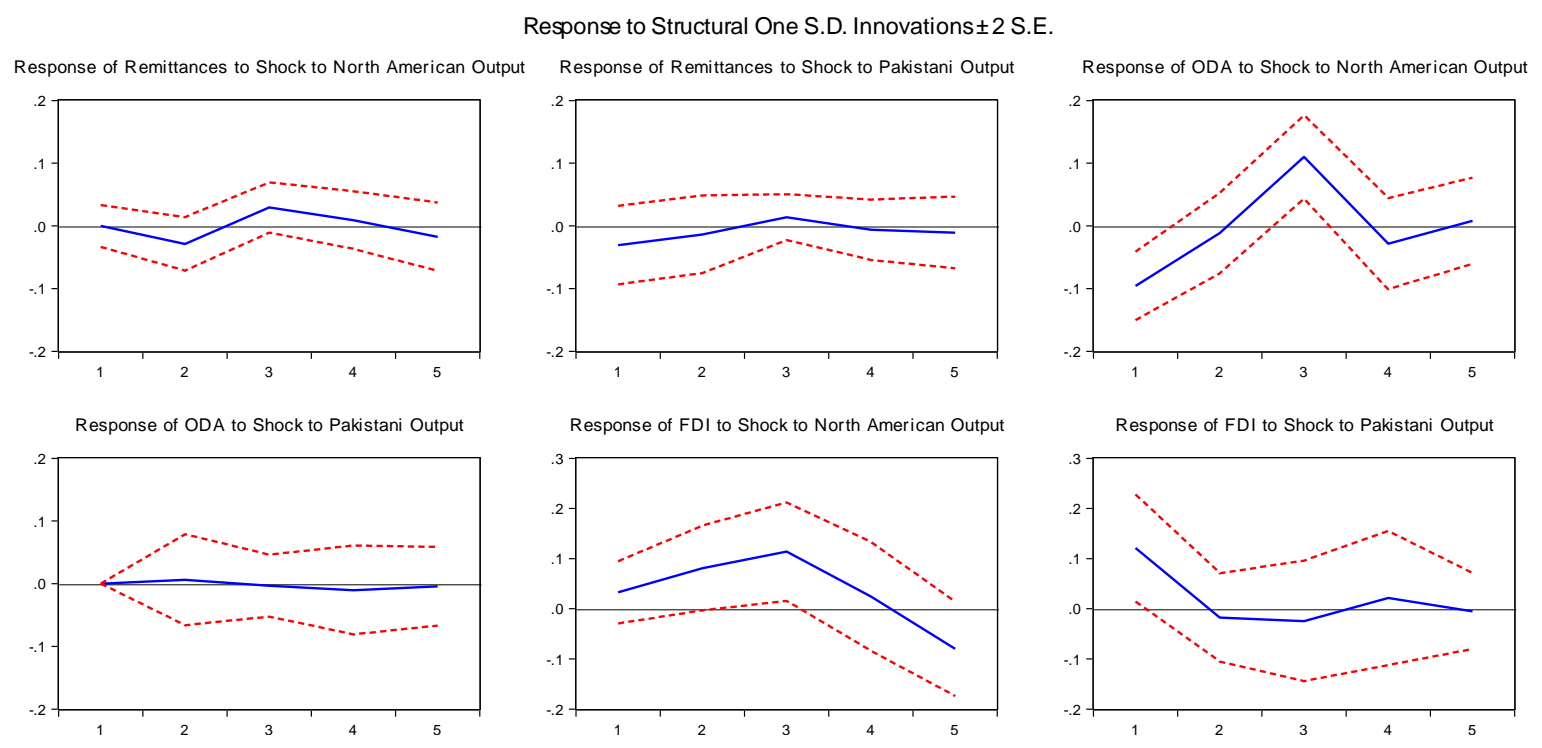

The response of remittances to a shock to North American output seems to be negative, but is not statistically significant. As regards the shock to the receiving economy, ODA and FDI respond pro-cyclically, that is, they increase when the Pakistan enters an economic boom and would decrease in periods of economic recession. In contrast, remittances appear to be counter-cyclical, but are not significantly associated with Pakistan's economic activity.

Figure 2.7. Response of Remittances, ODA and FDI to Shocks to European and Pakistani Output

Response to Structural One S.D. Innovations \pm 2 S.E
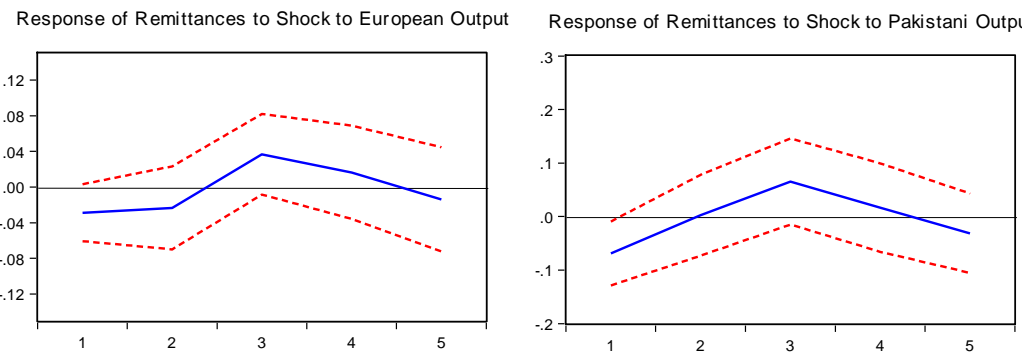

Response of ODA to Shock to European Output

Response of ODA to Shock to Pakistani Output

Response of FDI to Shock to European Output
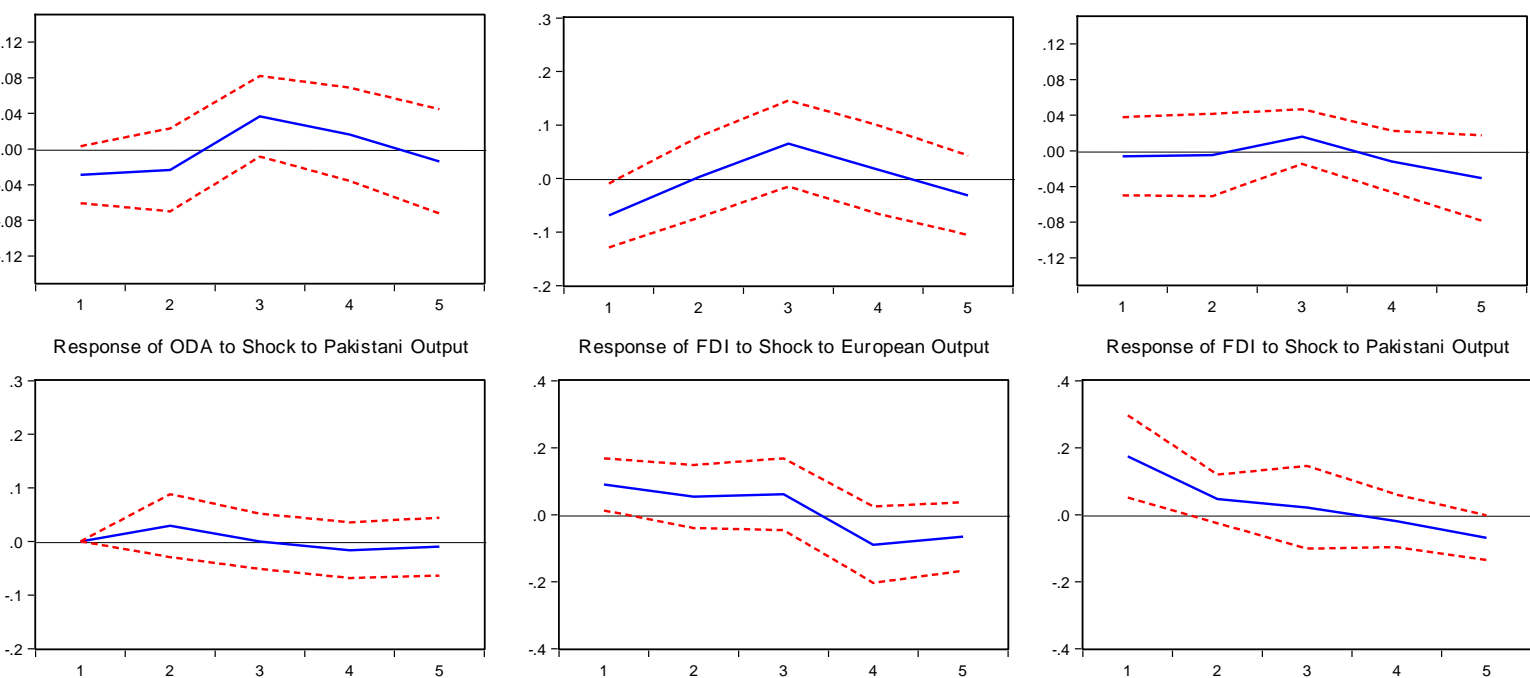

Response of FDI to Shock to Pakistani Output

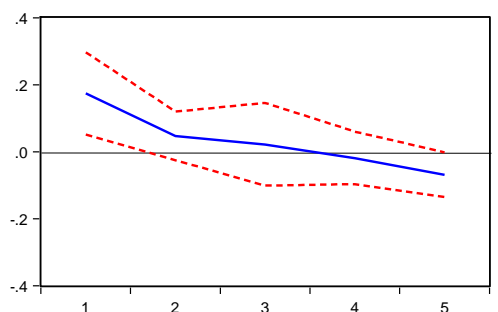


According to Figure 2.7, the response of FDI to innovations in European output tends to be procyclical. In contrast, the impulse response of remittances and ODA to a shock to European output remains insignificant. Similarly, it seems that a shock to the cyclical component of Pakistani output is negatively associated to remittance flows, confirming the altruistic motivation of migrants, an economic recession in the receiving country accompanied by an increase in the flows of remittances. Whereas, both FDI and ODA react pro-cyclical to shock to Pakistani output. However, the response of ODA to Pakistani output is temporary.

The responses of resource flows to output shocks in the Asia Pacific region and Pakistan are illustrated in Figure 2.8. ODA shows significant impulse response to innovations in Pakistani output. The response is counter-cyclical, albeit temporary.

Figure 2.8. Response of Remittances, ODA and FDI to shocks to Asia Pacific and Pakistani Output

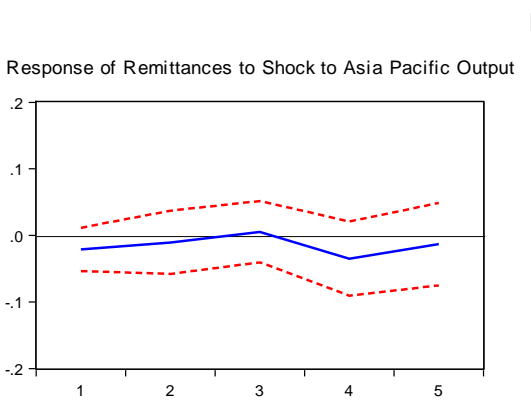

Response to Structural One S.D. Innovations \pm 2 S.E.

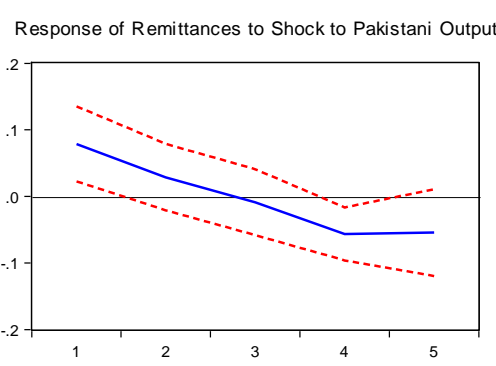

Response of ODA to Shock to Asia Pacific Output
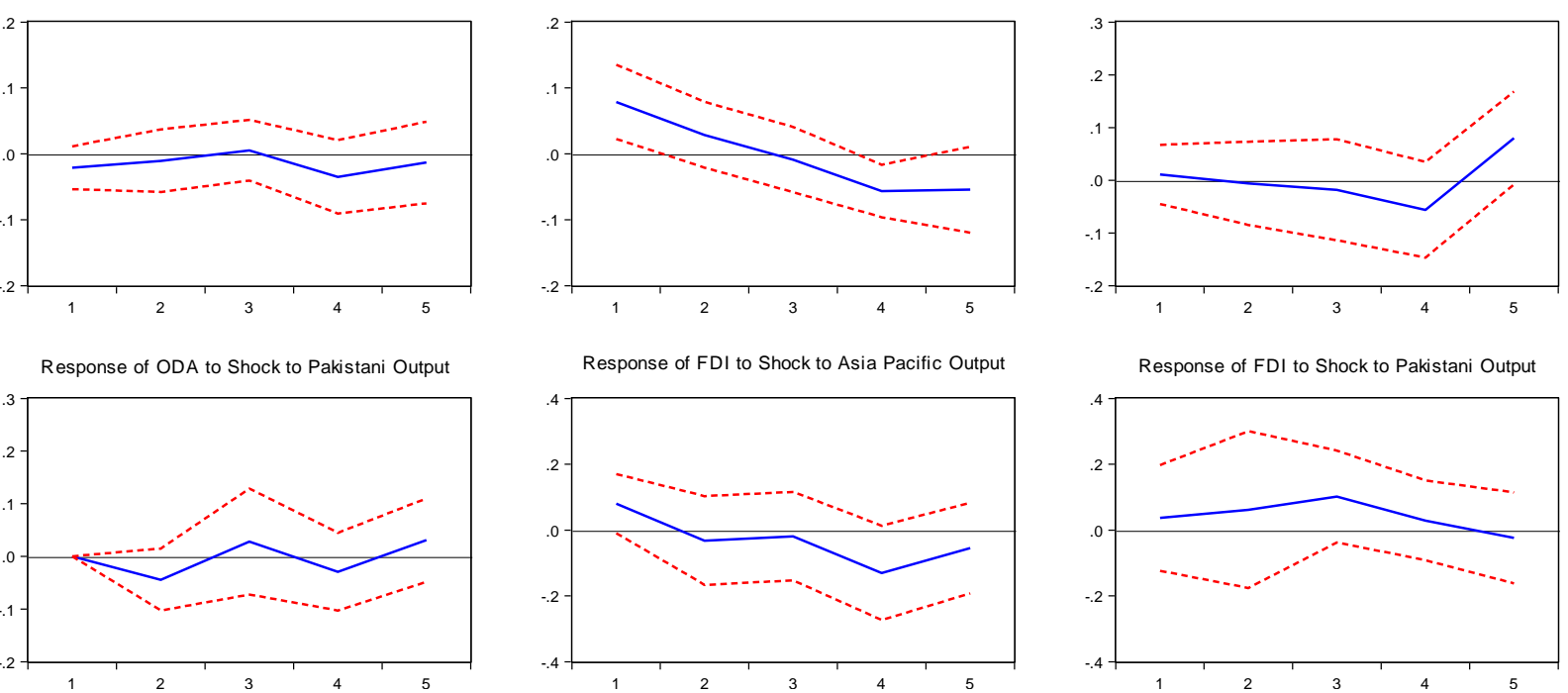

The initial impulse response of remittances to shocks to receiving output is positive and significant, before turning negative and significant in the fourth period. However, FDI appears as a-cyclical to shocks to Pakistani output. Similarly, we found no association between remittances, FDI or ODA and Asia Pacific output.

Having examined how migrants' remittances and other financial inflows to Pakistan respond to the receiving and sending countries business cycles, we now assess which of the two cycles is 
more important for Pakistan. We obtain forecast error variance decompositions corresponding to our SVAR models. These show the percentage of the variability that each shock accounts for in the total variation of the endogenous variable. The higher the share of the variable in the error variance, the more important the variable is in the system. We follow Sim and Bernanke (1986) to obtain forecast error variance decomposition. A variance decomposition of five future periods is reported. The variance decomposition reported in Table 2.6. depicts to what extent the forecast error variance in the cyclical component of remittances, FDI and ODA inflows to Pakistan explain structural shocks to Pakistan's and sending countries regional output. Table 2.6 shows that output are the main driving factor for remittances, since they explain around 47 percent of variation due to receiving output. The fraction of FDI variance explained by Pakistani output ranges between 13 and 43 percent.

Table 2.6. Error Variance Decomposition: Percentage of Variation in Capital Inflows Explained by Pakistani and Regional Outputs

\begin{tabular}{|c|c|c|c|c|c|c|}
\hline \multirow[t]{2}{*}{ Period } & \multicolumn{2}{|c|}{$\begin{array}{l}\text { Percentage of the variation in } \\
\text { Remittances explained }\end{array}$} & \multicolumn{2}{|c|}{$\begin{array}{l}\text { Percentage of the variation in } \\
\text { ODA explained }\end{array}$} & \multicolumn{2}{|c|}{$\begin{array}{l}\text { Percentage of the variation in } \\
\text { FDI explained }\end{array}$} \\
\hline & $\begin{array}{l}\text { Middle } \\
\text { East output }\end{array}$ & $\begin{array}{l}\text { Pakistani } \\
\text { Output }\end{array}$ & $\begin{array}{l}\text { North } \\
\text { American } \\
\text { output }\end{array}$ & $\begin{array}{l}\text { Pakistani } \\
\text { Output }\end{array}$ & $\begin{array}{l}\text { North } \\
\text { American } \\
\text { output }\end{array}$ & $\begin{array}{l}\text { Pakistani } \\
\text { Output }\end{array}$ \\
\hline 1 & 16.48 & 47.19 & 30.05 & 0 & 3.121 & 43.06 \\
\hline 2 & 30.22 & 26.54 & 26.75 & 0.111 & 11.91 & 23.35 \\
\hline 3 & 23.45 & 24.34 & 41.47 & 0.094 & 20.60 & 15.57 \\
\hline 4 & 18.94 & 20.70 & 37.57 & 0.259 & 17.74 & 13.42 \\
\hline 5 & 13.91 & 13.22 & 36.94 & 0.283 & 21.58 & 12.55 \\
\hline
\end{tabular}

However, a shock to regional output explains only a small portion of the variation in both remittances and FDI. Similarly, 41 to 27 percent of variance in inflows of ODA to Pakistan are due to North American output.

In general, the study shows that the inwards remittances and FDI to the country are typically affected by their innovations to Pakistani output rather than by sending countries output. However, inflows of ODA are mostly affected by output fluctuations in the sending country, rather than by Pakistani output.

\subsection{Discussion and Conclusions}

In this study, we examined the stability, cyclicality and stabilization impact of remittances together with other major financial flows. We employed different filtering methods, coefficient of 
variance analysis as well as a Structural VAR for this purpose. The results of the three empirical exercises are found to be harmonious.

We find that financial flows exhibit different types of volatility, remittances being more stable than ODA and, in turn, ODA being more stable than FDI. Remittances appear to be countercyclical and stabilizing, serving consequently as a macroeconomic stabilizer for the Pakistani economy. ODA appeared to be a-cyclical and stabilizing, whereas FDI is pro-cyclical and destabilizing. Moreover, no clear pattern of cyclicality is found for remittances with respect to sending-country output, suggesting that remittances are probably not the factor through which business cycles in the sending regions are affecting the economic conditions of Pakistan. However, we detected a positive association between FDI and sending-countries' real output. Similarly, based on SVAR identification, remittances from overseas workers are found to be countercyclical, which implies that remittances mitigate business cycle fluctuations in Pakistan. Meanwhile, FDI turned out to be pro-cyclical with respect to Pakistan economic conditions. However, the response appears to be insignificant in some cases. In contrast, results are inconclusive regarding the relationship between ODA and the economic conditions in Pakistan.

With regards to sending-region business cycles, remittances are a-cyclical except for the Middle East, where they display a counter-cyclical trend. Inflows of remittances and FDI to Pakistan appear to be typically affected by innovations in Pakistani output rather than by sending-country output. However, inflows of ODA are mostly affected by sending-country output fluctuations rather than by Pakistani output variations.

Our findings show that two features make remittances a more effective source of foreign exchange to Pakistan compared to FDI and ODA. Firstly, they are relatively stable and to a certain extent limit the variability in output. Given that remittances to Pakistan exceed the inflows of FDI and portfolio investments put together and cover a bulk of the country's foreign exchange deficit, this relative stability augurs well for the country's macroeconomic health. Secondly, remittance flows to Pakistan mainly respond to the domestic economic conditions, and very little to sending-country economic fluctuations. This makes them an automatic choice as a stabilizing tool. Allowing more convenient and cheaper remittance tools should therefore be an important policy goal. Nonetheless, to the extent that remittances are associated with home-country business cycle, they may prove a source of shocks to the economy. A long-term challenge for 
Pakistani policymakers should therefore be to find substitutes to reduce reliance on remittances, so that the country could better cope up with associated risks. 


\section{References}

Akkoyunlu, Ş., \& Kholodilin, K. A. (2008). A link between workers' remittances and business cycles in Germany and Turkey. Emerging Markets Finance and Trade, 44(5), 23-40.

Agarwal, R., \& Horowitz, A. W. (2002). Are international remittances altruism or insurance? Evidence from Guyana using multiple-migrant households'. World Development, 30(11), 2033-2044.

Ahmed, J. (2012). Cyclical properties of migrant's remittances to Pakistan: What the data tell us. Economics Bulletin 32(4), 3266-3278.

Amjad, R., Irfan, M., \& Arif, G. M. (2013). How to increase formal inflows of remittances: An analysis of the remittance market in Pakistan. International Growth Center, WP, May.

Anwar, A. I., \& Mughal, M. Y. (2012). Motives to remit: Some microeconomic evidence from Pakistan. Economics Bulletin, 32(1), 574-585.

Aning, K (2007). Security, the war on terror and official development assistance, theme paper prepared for the project on Southern perspectives on reform of the International Development Architecture.

Baxter, M and King, R G (1999). Measuring business cycles: Approximate band-Pass filters for economic time series. The Review of Economics and Statistics, 81, 575-593

Barajas, M. A., Chami, M. R., Ebeke, M. C., \& Tapsoba, M. S. J. A. (2012). Workers' remittances: An overlooked channel of international business cycle transmission? (No. 12-251). International Monetary Fund.

Bernanke, B. (1986). Alternative explorations of the money-income correlation, CarnegieRochester Series on Public Policy, 25, 49-99.

Blanchard, O.J., and D.T. Quah (1989). The dynamic effects of aggregate demand and supply disturbances. The American Economic Review, 79 (4), pp. 655-673

Blanchard, O.J. and M.W. Watson, (1986). Are business cycles all alike?, in Gordon, R. (ed.), The American business cycle: Continuity and change. University of Chicago Press, Chicago, 123-56.

Bulir, A, and A. J. Hamann (2003) Aid volatility: An empirical assessment. IMF Staff Papers, 50(1), 64-89.

Buch, C. M., \& Kuckulenz, A. (2010). Worker remittances and capital flows to developing countries. International Migration, 48(5), 89-117.

Burns, A. F., \& Mitchell, W. C. (1946). Measuring business cycles. NBER. 
Canova, F., (1998) Detrending and business cycle facts. Journal of Monetary Economics, 41, 475-540.

Chami, R., Fullenkamp, C., \& Jahjah, S. (2005). Are immigrant remittance flows a source of capital for development?. IMF Staff Papers,52(1).

Chami, R., Hakura, D., \& Montiel, P. (2009). Remittances: an automatic output stabilizer? (Vol. 9). International Monetary Fund.

Chauvet, L and P, Guillaumont (2009). Aid, volatility and growth again. when aid volatility matters and when it does not. Review of Development Economics, 13(3), 452-463

Corbae, D and Ouliaris, S (2006). Extracting cycles from non-stationary data, in Corbae, D, Durlauf, S N and Hansen, B E (eds.). Econometric Theory and Practice: Frontiers of Analysis and Applied Research, Cambridge University Press.

El-Sakka, M. and McNabb, R. (1999). The macroeconomic determinants of emigrant remittances. World Development, 27(8), 1493-1502.

Frankel, J. (2011). Are bilateral remittances counter-cyclical?, Open Economies Review, 22(1),. 1-16.

Gali, J. (1992). How well does the IS-LM model fit postwar US data?. Quarterly Journal of Economics 107 (2), 709-738.

Giuliano, P \& Ruiz-Arranz, M, (2009). Remittances, financial development, and growth, Journal of Development Economics , 90(1), 144-152.

Gujarati, D. (2004). Basic Econometrics. Fourth Edition, the McGraw-Hill Companies.

Hysenbegasi, A. and S. Pozo. (2002). What prompts workers to remit? Evidence using a panel of Latin American and Caribbean Nations. Working Paper, Western Michigan University

Hodrick, R.J. and E.C. Prescott, (1997). Post-war U.S. business cycles: An empirical investigation. Journal of Money, Credit and Banking, 29, 1-16

(IFC) International Finance Corporation (2011). Ease of doing business 2011, making a difference for entrepreneur, World Bank.

Khan, M. A., and Khan, S. A. (2011). Foreign direct investment and economic growth in Pakistan with sector analysis. Pakistan Institute of Development Economics Working Papers, 67

Khan H. Ashfaque (1997). Foreign direct investment in Pakistan: Policies and trends. Pakistan Development Review, 36(4)

Kock, U. \& Sun, Y. (2011). Remittances to Pakistan- Why have they gone up and why aren't they coming down? IMF Working Paper WP/11/200 
Kydland, F. E. and E. C. Prescott (1990). Business cycles: Real facts and a monetary myth. Federal Reserve Bank of Minneapolis Quarterly Review, 14,.3-18.

Lueth, E., \& Ruiz-Arranz, M. (2007). Are workers' remittances a hedge against macroeconomic shocks? The case of Sri Lanka (No. 2007-2022). International Monetary Fund.

Lueth, E., \& Ruiz-Arranz, M. (2008). Determinants of bilateral remittance flows. The BE Journal of Macroeconomics, 8(1).

Lucas and Stark (1985). Motivations to remit: Evidence from Botswana, Journal of Political Economy,. 93(5), 901-918.

Lucas, R.E., (1977). Understanding business cycles, in K. Brunner and A.H. Meltzer, eds., Stabilization of the Domestic and International Economy, Amsterdam: North Holland.

Malik, A. (2009). Quality and coordination of official development Aid in Pakistan, Working Paper 11. Washington, DC: Wolfensohn Center for Development.

Malik, Sohail. J., S. Aftab, and N. Sultana (1994). Pakistan's economic performance 19471993: A Descriptive Analysis, SURE Publishers Lahore, Pakistan.

Ministry of Finance, Government of Pakistan (2012). Pakistan Economic survey 2011-12. Government of Pakistan, Islamabad.

Mughal, M.Y. (2012). Remittances as development strategy: Stepping stones or slippery slope?" Journal of International Development, 24(8)

Mughal, M.Y. and Makhlouf, F. (2011) Volatility of remittances to Pakistan: What do the data tell?. Economics Bulletin, 31(1),. 605-612.

Mughal, M.Y. and Anwar, A.I. (2012). Remittances, inequality and poverty in Pakistan: Macro and microeconomic evidence. Working Papers 2012-2013_2, CATT - UPPA Université de Pau et des Pays de l'Adour.

Mughal, M.Y. and Ahmed, J. (2014). Remittances and business cycles: Comparison of South Asian countries, International Economic Journal, 28(2)

Neagu, I. C. and Schiff, M. (2009). Remittance stability, cyclicality and stabilizing impact in developing countries. The World Bank, Policy Research Working Paper Series 5077.

Orozco, M. (2003) Worker remittances in the international scope. Inter- American Dialogue Working Paper, commissioned by the Multilateral Investment Fund.

Pallage, S. and M.A. Robe (2001). Foreign aid and the business cycle. Review of International Economics, 9(4), 641-672. 
Quartey, P., (2007). Migrant remittances and household welfare in times of Macro volatility: the case of Ghana. ISSER Technical Publication Number 61, ISSER, University of Ghana. ISBN: 9964-75-057-9.

Ratha, D. (2003). Workers' Remittances: An important and stable source of external development finance. In Global Development Finance 2003, Striving for Development Finance, The World Bank, Washington D.C.

(2007). Leveraging remittances for development. Policy Brief, Migration Policy Institute, Washington DC.

Ravn, M. O., \& Uhlig, H. (2002). On adjusting the Hodrick-Prescott filter for the frequency of observations. Review of economics and statistics, 84(2), 371-376.

Suleri, A., and K. Savage. (2006). Remittances in crisis: A case study from Pakistan. Humanitarian Policy Group, Overseas Development Institute, London.

Spatafora, N., (2005). Workers' remittances and economic development, (Chapter II) in World Economic Outlook: Globalization and External Imbalances, IMF, Washington, DC, pp. 69-84.

Sayan, S. (2006). Business cycles and workers' remittances: How do migrant workers respond to cyclical movements of GDP at Home?. IMF Working Paper No. 06/52

Sayan, S., \& Tekin-Koru, A. (2012). Remittances, business cycles and poverty: the recent Turkish experience. International Migration, 50 (s1), e151-e176.

Shapiro, M. and Watson, M. (1988). Sources of business cycles fluctuations, in S. Fischer (ed.): NBER Macroeconomics Annual 1988, MIT Press, 3, 111-148.

Sims, Christopher A (1980). Macroeconomics and reality. Econometrica 48(1), 1-48.

Sims, C.A. (1986). Are forecasting models usable for policy analysis?" Quarterly Review of the Federal Reserve Bank of Minneapolis, 10, 2-16.

State Bank of Pakistan (2012). Net inflow of foreign private investment- Country-wise and by economic group.

OECD (Organisation for Economic Co-operation and Development) (2013). ODA receipts and selected indicators for developing countries and territories.

UNCTAD (2013). UNCTADstat. New York: United Nations.

Vargas-Silva, C. (2008). Are remittances manna from heaven? A look at the business cycle properties of remittances. North American Journal of Economics and Finance, 19, 290-303

World Bank (2006). Global economic prospects: economic implication of remittances and migration. Washington, D. C: World Bank. 
(2012) Migration and development brief 19. Washington, DC, Migration and Remittances Unit, Development Prospects Group

WDI (2013). World Development Indicators. Online Database, World Bank.

Woodruff, Christopher, and Rene Zenteno. (2001) Remittances and microenterprises in Mexico. Unpublished paper, University of California, San Diego.

Yang, D. and Choi, H. (2007) Are remittances insurance? Evidence from rainfall shocks in the Philippines. World Bank Economic Review, 21(2), 219-248. 


\section{Appendix}

\section{A.2.1 Statistical Significance of Cross-Correlations}

In order to calculate the statistical significance of these correlation coefficients, the null hypothesis $H_{0}: \rho=0$ is tested against the two-sided alternative hypothesis that $H_{A}: \rho \neq 0$, using the correlation coefficients, $r$, calculated from the given samples over the period 1974-2011.

In deciding whether to reject or not reject the null hypothesis, the critical t-values are determined according to $t=r \cdot \sqrt{\frac{n-2}{1-r^{2}}}$

Where $n$ is the number of observations in each sample. With $n=37$ this value is expected to

Fall with a $95 \%$ probability into the $[-2,2]$ bracket, when the null hypothesis is true.

$$
t^{2}=\frac{r^{2}(n-2)}{\left(1-r^{2}\right)}
$$

So, by rearranging terms in equation (2), we obtain

$$
\begin{gathered}
\frac{n-2}{t^{2}}=\frac{1-r^{2}}{r^{2}} \Rightarrow \frac{37-2}{( \pm 2)^{2}}=\frac{1-r^{2}}{r^{2}} \Rightarrow \frac{35}{( \pm 2)^{2}}=\frac{1}{r^{2}}-1 \\
9.8=\frac{1}{r^{2}} \Rightarrow r= \pm(9.8)^{-0.5} \cong 0.32
\end{gathered}
$$

In our study the correlation that falls outside the $(-0.32,0.32)$ range requires the null hypothesis to be rejected (Sayan and Tekin-Koru, 2012). 
Table A2.7. ADF Test Results for Unit Root Tests

\begin{tabular}{lllll}
\hline \multicolumn{1}{c}{ Variables' } & Level & HP Filter & BK Filter & CO Filter \\
\hline Remittances & & & & \\
\hline Foreign Direct Investment & $-2.54(0)$ & $-5.50 *(1)$ & $-4.78^{*}(1)$ & $-5.29 *(1)$ \\
\hline Official Development Assistance & $-3.48(3)$ & $-5.18 *(0)$ & $-4.18^{*}(0)$ & $-5.70^{*}(4)$ \\
\hline Pakistanis Output & $-1.35(1)$ & $-7.55^{*}(1)$ & $-6.61 *(1)$ & $-5.01 *(5)$ \\
\hline North American Output & $-1.62(1)$ & $-5.19^{*}(1)$ & $-4.27 *(1)$ & $-4.73^{*}(1)$ \\
\hline Middle East Output & $-2.37(0)$ & $-4.83^{*}(3)$ & $-4.60^{*}(0)$ & $-5.07 *(3)$ \\
\hline European Output & $-1.04(1)$ & $-5.68^{*}(1)$ & $-3.74 *(7)$ & $-5.21 *(8)$ \\
\hline Asia Pacific Output & $-1.40(0)$ & $-5.68^{*}(1)$ & $-4.78^{*}(1)$ & $-4.77^{*}(8)$ \\
\hline
\end{tabular}

ADF represents the Augmented Dickey-Fuller unit root test with trends for the original and the detrended series. * and $* *$ represents $1 \%$ and 5\% significance level, respectively. For Lag length selection, the SIC criterion was used. HP, BK and CO filter denote Hodrick Prescott, Baxter and King and Corbae and Ouliaris filters. 


\title{
Chapter 3 :Do transfer costs matter for foreign remittances? A gravity model approach
}

Joint work with Inmaculada Martinez-Zarzoso ${ }^{\dagger}$

\begin{abstract}
Using bilateral data on remittance flows to Pakistan for 23 major host countries, in the first study of its kind, we examine the effect of transaction costs on foreign remittances. We find that the effect of transaction costs on remittance flows is negative and significant; suggesting that a high cost will either refrain migrants from sending money back home or make them remit through informal channels. This can be better understood in terms of migrant networks and improvements in home and host country financial services. Distance, which has been used in previous studies as an indicator of the cost of remitting, is found to be a poor proxy.
\end{abstract}

Key words: Remittances, geographical distance, transaction cost, financial services, Pakistan.

JEL-Codes: F22, F30, 011

\section{Acknowledgment}

The authors gratefully acknowledge the comments and suggestions made by Prof. Stephan Klasen. We also would like to thank the participants at the IS Academy: Migration and Development ,16th Göttingen Workshop for International Economics, 12th Arnoldshain Seminar as well as the 2015 Annual Conference of the Research Group on Development Economics for their valuable inputs.

\footnotetext{
${ }^{\dagger}$ Department of Economics, University of Göttingen, Germany and University Jaume I in Castellón, Spain.
} 


\subsection{Introduction}

One of the principal factors that encourage migration across national boundaries is the difference in expected real earnings adjusted for migration cost (Borjas, 1999; Stark and Taylor, 1991). The costs incurred during the migration process are considered to increase with distance from the migrant sending to the migrant hosting country, and decrease as social networks in the hosting country grow (Ozden and Schiff, 2006). As migration is often thought to be a family decision (Borjas, 1999), the resulting remittances should be a central element of familial arrangements (Rapoport and Docquier, 2006). As a result, the physical distance between the migrant and the staying-behind household can affect remittance patterns (Rapoport and Docquier, 2006). Remittances might decrease with distance in the following three ways: Firstly, remittances might be motivated by altruistic reasons, and altruism might decrease if distance rises and associated contact falls. Secondly, migration to far-off lands might reinforce strategic behavior as greater distance from the family may reduce the enforcement capability of any family arrangement agreed prior to migration. Finally, remittances may decrease with distance if the latter were a good proxy for transfer costs (Lueth and Ruiz-Arranz, 2008; Frankel, 2011). At the other end of the spectrum, remittances may increase with distance in the context of loan repayment hypothesis (De Sousa and Duval, 2010). An increase in physical distance between migrant home and host countries can result in an increase in remittances in return for the high migration cost paid by the family (De Sousa and Duval, 2010). Clearly, these interpretations are conflicting. A competing interpretation is that the cost of transferring money might be unrelated to geographic distance and hence sending remittances should not necessarily be related to geographical features. There are two ideas behind this interpretation. Foremost, financial assets are "weightless" and are not subject to transportation costs (Portes and Rey, 2005). Furthermore, distance is unable to pick up technological changes. Conversely, remittances costs may indeed reflect technological developments and increase competition in the financial-services industry. These factors reduce the cost of sending remittances through the formal financial sector (Freund and Spatafora, 2008). Beck and Pería, (2011) additionally illustrate that corridors with a larger number of migrants and higher competition exhibit consistently lower costs, indicating that migration networks could also influence the cost of remitting. 
Remittances sent to developing countries via the official channel have increased more than tenfold over the last decade. The amount reached $\$ 404$ billion in 2013 , growing by 3.5 percent compared with 2012 (World Bank, 2014a). This overwhelming growth in remittances is partly due to increase migrant stocks and rising remittances per immigrant. It may also be attributed to the better recording of data as well as a shift from informal to formal channels induced by falling cost of remitting money home. However, the prevalence of informal transactions is still likely to be substantial. Freud and Spatafora (2008) argue that informal remittances amount to about 3575 percent of recorded remittances to developing countries. This is due to lower transaction fees generally charged by informal channels ${ }^{14}$. Compliance with regulations to counter terrorism financing and anti-money laundering could be a major cost factor putting upward pressure on prices, thus leading sizeable flows to underground channels (World Bank, 2014a).

None of the abovementioned studies have investigated the cost of remitting as a factor influencing remittances flows. Hence, the effect of implementing policies in the receiving country to facilitate the transfers and lower the cost remains an empirical question. For this reason, the main aim of this paper is to provide an estimate of the effect of transaction costs on remittances and to evaluate the magnitude of this effect. At the conceptual level, the contribution is also the comparison of the effect of distance with the effect of remittance costs. At the empirical level, this is the first country-study of this kind for the South Asian region. Given that the region accounts for the highest share of world wide remittances, the results could be helpful in better understanding these remittance flows. More specifically, we estimate a gravity model using panel data for remittances from 23 sending countries ${ }^{15}$ to Pakistan over the period from 2001 to 2013. The model is augmented with a new proxy for cost of remitting that, to the best of our knowledge, has never been used in previous studies. Moreover, we also include migration networks in the analysis as an important factor explaining the variation of remittances over time. The cost of remitting has been constructed using the real cost of sending money for a number of countries (including a representative country in each regional area) for which the data are available for a period of 4 years. We have estimated a model of the determinants of the cost of

\footnotetext{
${ }^{14}$ According to Sander (2004), the average cost of remitting at 3 to 5 percent in most cases when using informal channel, whereas Orozco (2003) suggest the costs to be less than 2 percent of the principal value in the case of informal source such as hawala or hundi

15 The countries considered include: Australia, Bahrain, Belgium, Canada, Denmark, France, Germany, Greece, Ireland, Italy, Japan, Kuwait, the Netherlands, Norway, Oman, Qatar, Saudi Arabia, Spain, Sweden, Switzerland, UAE, the UK, and the US.
} 
remitting to extrapolate this information to our whole sample. The main variables used to predict the cost of remitting are proxies for the financial development in both home and host countries and migrant stocks.

To the best of our knowledge, this is the first paper that incorporates into the model a variable that measures the cost of sending remittances. Moreover, we also include migration networks in the analysis as an important factor explaining the variation of remittances over time.

We focus on Pakistan because it is among the top ten remittance receiving countries in the world and relies heavily on international transfers. The development potential of these transfers is therefore of great importance.

The rest of the paper proceeds as follows. Section 2 presents Pakistan's migration and remittance main features. Section 3 discusses remittances cost. Section 4 reviews the literature, focusing particularly on bilateral remittance determinants. Section 5 employs a gravity model framework to examine the main determinants of remittance flows using bilateral data. Results are presented in section 6. Section 7 concludes and outlines a number of policy implications.

\subsection{Overview of Bilateral Migration and Remittances to Pakistan}

The first major wave of migration from Pakistan began in the 1970s when thousands of Pakistani workers left for the states of the Persian Gulf to participate in the development of the newly-rich oil economies. By 2013, about 5.7 million Pakistani immigrants were estimated to reside abroad, compared with 3.7 million in 2000 and 3.6 million in $1990^{16}$ (United Nation, 2014). This shows that 54 percent of this growth in migrants stock took place during the period 2000-2013. Factors driving this wave of migration include economic slowdown, increasing poverty, rapid population growth and substantial wage differentials (Ministry of Finance, 2013; Irfan, 1999).

Among the immigrants destination countries, the Middle East is the most popular destination region accounting for more than half of Pakistani migrants, followed by North America, Europe, and Asia Pacific (UN, 2014). Saudi Arabia and the United Arab Emirates (UAE) host the largest Pakistani migrants communities, possibly due to geographical proximity and cultural affinity.

\footnotetext{
${ }^{16}$ This corresponds to around 2.2 percent of the country population in 2013 residing abroad compared to 2.9 percent in 2000 and 5.9 percent in 1990 .
} 
Moreover, the Gulf region also has attracted a large proportion of immigrants due to the availability of medium- and low-skilled jobs (Arif, 2009).

The United States (US), Canada, the United Kingdom (UK), Italy, and Spain are also countries with sizeable Pakistani overseas communities. At present, rapidly growing Southeast Asian economies such as Malaysia and Singapore, and Australia are attracting an increasing number of Pakistani workers (UN, 2014). The presence of such a significant number of immigrants has not only accelerated the integration of Pakistan into the world economy, but has also translated into a large flow of remittances back home.

Table 3.1. Remittance flows per immigrant by host countries

\begin{tabular}{|c|c|c|c|c|c|c|}
\hline \multirow[t]{2}{*}{$\begin{array}{l}\text { Host } \\
\text { Countries }\end{array}$} & \multicolumn{2}{|c|}{$\begin{array}{l}\text { Remittances by host } \\
\text { countries }\end{array}$} & \multicolumn{2}{|c|}{$\begin{array}{l}\text { Share of remittances } \\
\text { from host with total } \\
\text { remittances. (in percent) }\end{array}$} & \multicolumn{2}{|c|}{$\begin{array}{l}\text { Share of remittances } \\
\text { per immigrant }\end{array}$} \\
\hline & $\underline{2001}$ & $\underline{2013}$ & $\underline{2001}$ & $\underline{2013}$ & $\underline{2001}$ & $\underline{2013}$ \\
\hline GCC & 693.22 & 8462.78 & 63.83 & 60.79 & 251.08 & 1354.61 \\
\hline -Bahrain & 23.87 & 282.83 & 2.20 & 2.03 & 367.23 & 2405.61 \\
\hline -Kuwait & 123.39 & 619.00 & 11.36 & 4.45 & 1142.50 & 3453.78 \\
\hline -Qatar & 13.38 & 321.25 & 1.23 & 2.31 & 243.27 & 3209.20 \\
\hline -Saudi Arabia & 304.43 & 4104.73 & 28.03 & 29.48 & 178.87 & 1214.14 \\
\hline$-U A E$ & 190.04 & 2750.17 & 17.50 & 19.75 & 307.01 & 1423.61 \\
\hline -Oman & 38.11 & 384.80 & 3.51 & 2.76 & 179.76 & 715.39 \\
\hline North & 139.71 & 2363.59 & 12.86 & 16.98 & 474.70 & 4763.44 \\
\hline \multicolumn{7}{|l|}{ America } \\
\hline - Canada & 4.90 & 177.19 & 0.45 & 1.27 & 61.78 & 1127.75 \\
\hline$-U S A$ & 134.81 & 2186.40 & 12.41 & 15.70 & 627.02 & 6448.11 \\
\hline Euro Area & 112.87 & 2371.59 & 10.39 & 17.04 & 235.02 & 3013.14 \\
\hline - Belgium & 1.10 & 3.34 & 0.10 & 0.02 & 275.00 & 256.92 \\
\hline -Denmark & 3.83 & 25.03 & 0.35 & 0.18 & 900.33 & 1973.04 \\
\hline -France & 2.22 & 36.26 & 0.20 & 0.26 & 222.00 & 1842.85 \\
\hline -Germany & 9.20 & 83.18 & 0.85 & 0.60 & 262.86 & 2122.59 \\
\hline -Greece & 0.00 & 11.18 & 0.00 & 0.08 & 0.00 & 455.42 \\
\hline -Ireland & 0.20 & 90.07 & 0.02 & 0.65 & 66.67 & 11982.17 \\
\hline -Italy & 0.55 & 35.74 & 0.05 & 0.26 & 27.50 & 499.80 \\
\hline -Netherlands & 3.60 & 5.45 & 0.33 & 0.04 & 327.27 & 459.22 \\
\hline -Norway & 5.74 & 37.84 & 0.53 & 0.27 & 410.00 & 1861.84 \\
\hline -Spain & 0.06 & 53.44 & 0.01 & 0.38 & 4.00 & 709.87 \\
\hline -Switzerland & 4.24 & 30.37 & 0.39 & 0.22 & 1060.00 & 6927.46 \\
\hline -Sweden & 0.74 & 13.68 & 0.07 & 0.10 & 246.67 & 1248.40 \\
\hline$-U K$ & 81.39 & 1946.01 & 7.49 & 13.98 & 229.92 & 4087.02 \\
\hline Asia Pacific & 8.08 & 182.34 & 0.74 & 1.31 & 384.76 & 4133.76 \\
\hline -Japan & 3.93 & 177.19 & 0.36 & 1.27 & 491.25 & 16681.42 \\
\hline -Australia & 4.15 & 149.73 & 0.38 & 1.08 & 319.23 & 4471.15 \\
\hline Other & 132.69 & 568.88 & 12.22 & 4.09 & & \\
\hline Total & 1086.60 & 13921.70 & & & 305.52 & 1837.91 \\
\hline
\end{tabular}


This flow plays an increasingly important role in easing difficulties facing the country's economy in terms of foreign exchange, balance of payments, and economic growth (State Bank of Pakistan, 2012).

For many developing countries facing a weak balance of payments situation such as Pakistan, remittances have emerged as a large source of foreign exchange earnings. The flows reached about $\$ 14$ billion in 2013, compared with \$1 billion in 2001(see Table 3.1). Similarly, this increase in remittances has outpaced that of net ODA and FDI, which accounted for only \$2.17 billion and $\$ 1.31$ billion in 2013 respectively (WDI, 2014).

Likewise, compared to FDI and foreign aid, remittances tend to be resilient and increase during periods of economic turmoil (Ahmed and Martinez, 2013, Mughal and Makhlouf, 2011).

Table 3.1 also indicates that Saudi Arabia, the USA, the UAE, and the UK represent Pakistan's main remittance sending countries. The Middle East region accounts for more than 60 percent of overall remittances, which are mainly sent from Saudi Arabia and the UAE. Overall, the share from major remittances corridors has increased over the period 2001-2013. Remittances per immigrant, however, portray a somewhat different picture, with more flows coming from developed nations such as the USA, Australia, and the UK.

\subsection{Cost of remitting to Pakistan}

Pakistani migrants use various channels to send money from the host country to their families back home. These include banks, money transfer operators such as Western Union and Money Gram, family members, and friends as well as the so-called "hawala or hundi"," Family, friends, and hundi are considered informal channels and are not recorded in the official statistics. In a study of remittances to Pakistan from Saudi Arabia, Arif (2009) points out that in 2009 about 38 percent of the remittances were transferred through the banking system, 28 percent through hundi, 17.9 through friends/relatives and 13.7 percent through migrants' home visits. There is no difference in the reported cost of transfer money either through bank or hundi. However, the distance from the closest bank and the amount of time required for each transaction are the main factors pushing migrants and their families to use the hundi system. In another study, Amajd et al.

\footnotetext{
${ }^{17}$ This is an informal method, which is comparatively cheaper than the formal transaction channel. The sender contacts a broker who acts as an intermediary and arranges the transfer. The sender remits a certain amount in Saudi Riyal and the broker contacts a counterpart in Pakistan, who makes the payment in Pakistani rupees to the family. Throughout the whole procedure, no money crosses the border, and no official records exist for this transaction.
} 
(2013) mentioned that the time required to withdraw money from the nearest bank and the high transaction costs are the main barriers to using the banking channel. Therefore, the transaction costs of sending remittances and in particular the fees paid to intermediaries continue to be a significant concern for immigrants, development agencies, and other actors involved in the process.

The World Bank has constructed a database that contains the cost of sending remittances to families back in the home country. The average cost for sending remittances from the major remittances corridor was 8.0 percent in 2011 and has fallen to 6.2 percent of the amount remitted in 2014. Figure 3.1 shows the cost of sending remittances with a significant heterogeneity across major remittances corridors.

Figure 3.1. Average cost for sending remittances (as a share of funds sent) to Pakistan from major remittances corridors

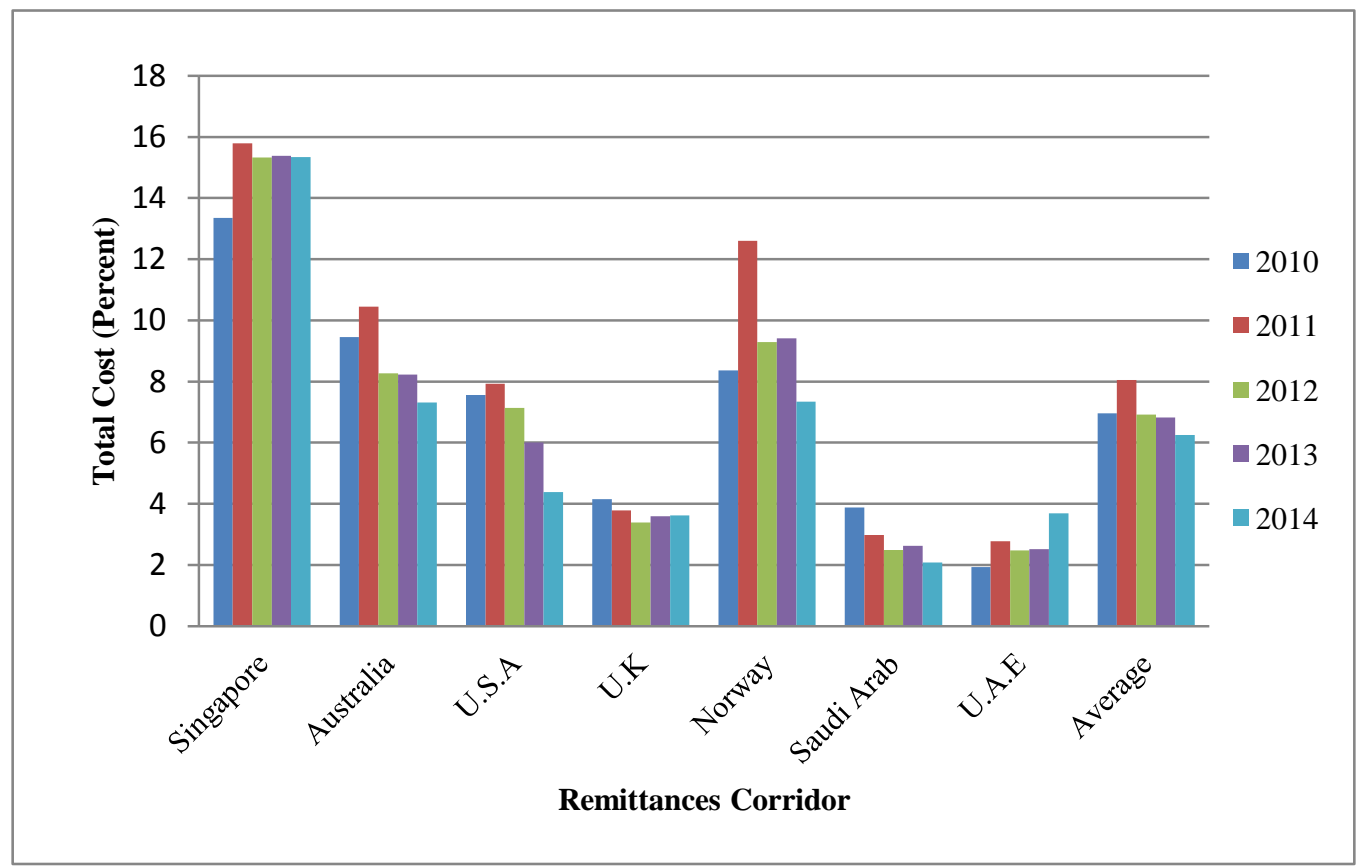

Source: World Bank Remittances Prices Worldwide. All figures are percentages.

In particular, the Figure 3.1 reveals that it is significantly cheaper to send remittances to Pakistan from Saudi Arabia, UAE and the UK than from the other considered countries. Hence, the Middle East region is the least expensive corridor with the cost being between 1.9 and 3.8 percent. Conversely, Singapore and Norway show the highest transfer costs, going up to around 15.5 percent in 2014 in Singapore. It is the most costly for a Pakistani resident to send money back 
home from Singapore with the cost being over 15 percent of the transfer. Sending money from Norway consistently costs more than twice, on average, than from the UK. This high transaction cost is probably one of the main obstacles that deters the use of remittances in the development process (Orozco, 2003, World Bank, 2014a). Some studies have shown that these flows are very sensitive to cost and are more likely to rise with a drop in costs (Gibson et.al, 2006). Therefore, high transaction costs, duration of the transfer, lower fees on informal transactions and lack of access to convenient remittance services encourage migrants to use informal channels. As an option to reduce these costs, the Pakistan Remittance Initiative (PRI) was launched in 2009 as a joint project of the Ministry of Overseas Pakistanis, the State Bank of Pakistan (SBP), and the Ministry of Finance (Ministry of Finance, 2013). Under this scheme neither the remitter nor the beneficiary is supposed to pay any fee to the transfer company. In 2012, the National Database and Registration Authority (NADRA) has launched the 'National Cash Remittance Program' to enable more than 117 NADRA centers to process inward home remittances from overseas for the general public using smart national identity cards. Similarly, the adoption of improved technology, such as cell-phone services help to enable remittances ${ }^{18}$ (World Bank, 2014a). The implementations of targeted government policies as well as the use of better technologies aimed at easing remittances are both putting downward pressure on the cost of remitting to the country.

A comparison between transaction costs and geographical distance could be illustrative of the important differences between both variables. The cost to transfer $\$ 200$ to Pakistan from the UK was 3.6 percent despite a capital-to-capital distance of $6049.92 \mathrm{kms}$, while the cost of transferring the same amount from Norway is 9.41 percent, with a distance of $5308.44 \mathrm{kms}$; and an even higher 15.37 percent from Singapore despite a smaller distance of $4819.49 \mathrm{kms}$.

\footnotetext{
${ }^{18}$ For example, in a short period of time Pakistan has become mandated in branchless banking with over 1percent of the population holding branchless banking accounts with key services such as Easypaisa, UBL Omni and services from banks and the Pakistan Post office obtaining traction (Oak , 2013).
} 
Figure 3.2. Comparison of geographical distance and transaction cost of remittances to Pakistan from selected host countries, 2013)

Total cost (in percent)

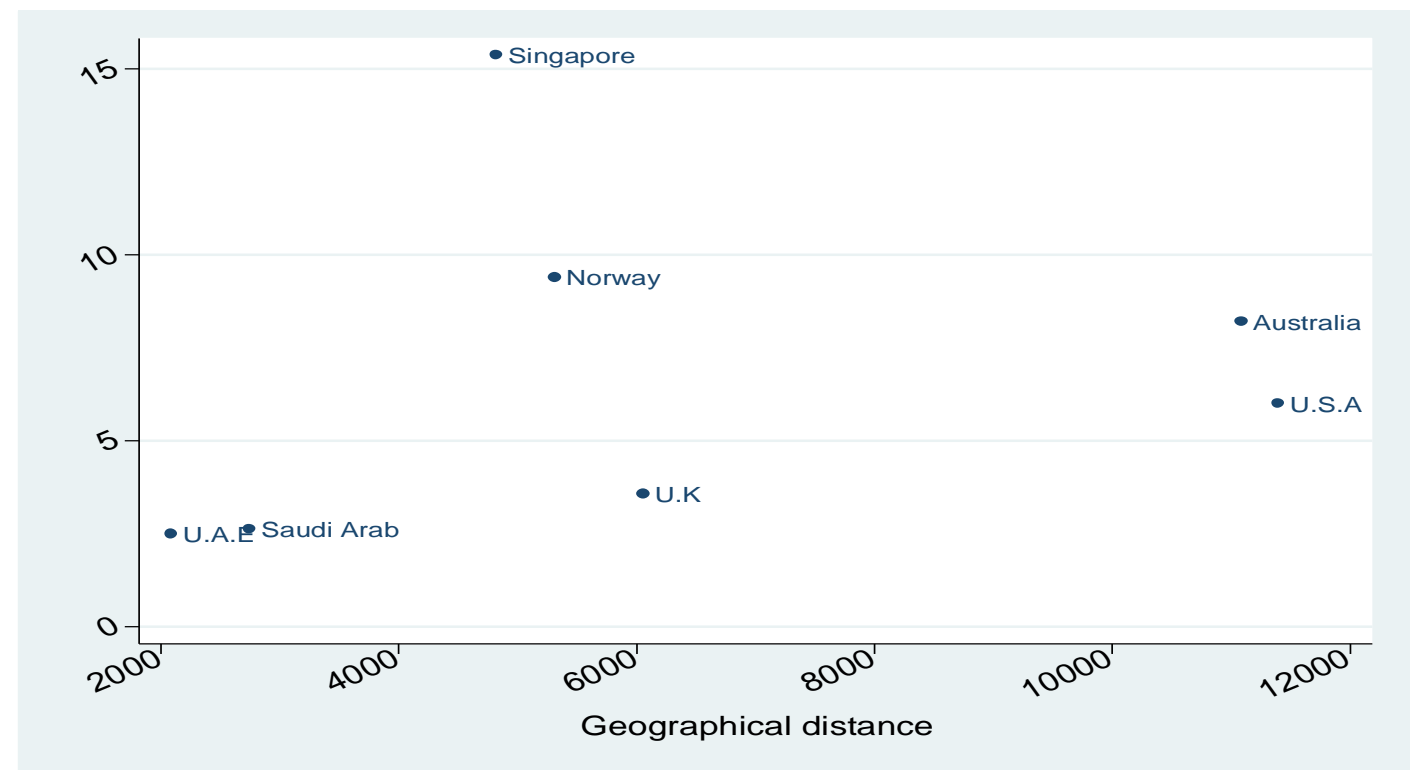

Note: Information on transaction cost was collected in May 2013. The cost includes the fee and the exchange rate margin of transferring \$200. Source: CEPII and World Bank Remittances Prices Worldwide. All figures are in percentages.

This shows that transaction costs are not exclusively determined by the distance from the host country's to the home country (see Figure 3.2).

\subsection{Factors behind bilateral remittances flow. A brief literature review}

Recent literature has highlighted the importance of geographical distance and other bilateral variables in driving remittances. Empirical evidence in this regard is still scarce mainly due to limited data availability concerning bilateral remittances over time. We discuss in this section the related literature, starting by studies covering different countries and region and focusing next on existent studies for Pakistan. To the first group of studies belong Lueth and Ruiz-Arranz (2008). The authors model remittances for eleven countries in Asia and Europe for the period 1980-2004 and construct a dataset of bilateral remittance flows for a set of 33 developing countries with remittances to 11 home countries: Bangladesh, Croatia, Indonesia, Kazakhstan, Macedonia, Moldova, Philippines, Serbia and Montenegro, Slovenia, Tajikistan and Thailand. They include several variables that appear frequently in the trade literature as determinants of remittances, namely the GDP of home and host countries, geographical distance, common language, colonial 
ties, stock of immigrants, political risk, etc. Their results indicate that economic activity in the host and home country and other gravity variables account for more than 50 percent of the variation in remittances. Similarly, Frankel (2011), using the same dataset, finds that distance is negatively associated with remittances while income per capita of the host country is positive and highly significant across all specifications. However, other gravity variables such as common border and common language variables are not statistically significant.

The opposite result regarding the significance of geographical distance is found by Schiopu and Siegfried (2006) when using a panel dataset of bilateral remittances from 21 European sending countries to 9 European receiving countries over the period 2000-2005. They find that geographical distance plays no role in explaining remittances. However, the effect is positive if the countries have no common border. In another related study, De Sousa and Duval (2010) examine remittance flows to Romania originating from various sending countries during the period 2005-2009. The authors find that both home and host countries' economic size and geographical distance appear to positively impact bilateral flows. The positive relationship between remittances and distance is supported by the loan repayment hypothesis, according to which an increase in physical distance between migrant sending and receiving countries results in an increase in remittances in return for the high migration cost paid by the family.

Only two studies have analyzed the remittance motives in the Pakistani context. The first study by Bouhga-Hagbe (2006) points to the existence of altruistic motives for sending remittances. Those are proxied by "agriculture GDP" and are found to be a major driver of remittance flows to Egypt, Jordan, Morocco, Pakistan, and Tunisia. The second, by Kock and Sun (2011), suggests that skill level, investment return in both host and home countries, nominal and real exchange rates, and domestic economic conditions are the main factors explaining remittances to Pakistan.

A discussion of the existing literature shows that though the role of home and host country economic conditions has often been explored and found to be an important determinant of migrants' remittances, the role of geographical distance used as a proxy for transferred cost needs further analysis. To date, few studies have examined the bilateral macroeconomic determinants of remittances and hence this study aims at closing this gap in the literature. Previous studies have merged different data to obtain bilateral remittances, which allows for more comprehensive 
conclusions. However, in the absence of international harmonization, remittances are documented in a different way in each country (De Sousa and Duval, 2010). In this study, the datasets used are constructed in a more homogenous way for a single home country (i.e. Pakistan), which implies using a smaller sample, but avoids the drawbacks of previous datasets concerning measurement differences.

Summarizing, we extend the literature in two important ways. Firstly, by focusing on a new factor, the cost of sending remittances, and emphasizing that distance cannot be used as a proxy for this factor, and secondly by using a homogenous dataset.

\subsection{Empirical strategy}

\subsubsection{Gravity model of bilateral remittances}

We start by estimating a simple gravity equation where the bilateral remittance flows are explained by the GDPs of both the host ( $i$ ) and the home country $(j)$, and by a set of transaction costs proxies including, in particular, the cost of remitting (Remcost $t_{i j}$ ) and the geographical distance between a pair of countries (DIST ${ }_{i j}$ ). The theoretical justification of the gravity equation for bilateral remittances is not as well established as for trade flows (see Anderson, 1979; Bergstrand, 1990; Feenstra et al., 2001 and Anderson van Wincoop, 2003). However, the model has been further extended for the analysis of international capital flows as well as for international migration (Mayda, 2010; Karemera et al. 2000; Lewer and Berg, 2008) and has been applied to explain remittances (De Sousa and Duval; Lueth and Ruiz-Arranz, 2008) and, more extensively, FDI flows (Hattari and Rajan, 2008; Bénassy-Quéré et.al, 2007; Demekas et al., 2005).

In this study, we employ a parsimonious model which includes commonly-used determinants while focusing on specific bilateral variables. Similar to the gravity model used in the trade literature, the starting point of the gravity model of migration is the hypothesis that immigration is driven by differences in economic size and impeded by migration costs (Borjas, 1999).

Lueth and Ruiz-Arranz (2008) argue that bilateral remittances can also be modeled using the gravity model. We start by specifying the basic gravity model, which argues that bilateral remittances are directly proportional to the economic size of the host and home country measure by GDP, and inversely proportional to the distance between the two countries (Lueth and Ruiz- 
Arranz, 2008). The greater the distance between two countries, the higher the cost of remitting, thereby reducing the amount of remittances to the country.

The gravity model of remittances is given by,

$$
R E M_{i j t}=A \frac{\left(G D P_{i t} * G D P_{j}\right)^{\alpha_{1}}}{\left(D_{i s t_{i j}}\right)^{\alpha_{1}}} Z_{i j t}
$$

where GDP denotes income in host $(i)$ and home $(j)$ country. Pakistan is considered the "home country" and the rest of the 23 source countries are used as "host countries". Dist denotes geographical distance between capitals of countries $i$ and $j$, and $Z$ represents a number of control variables.

By taking natural logs of equation (3.1), we adopt a similar empirical specification as in Lueth and Arranz (2008) and De Sousa and Duval (2011). The linearized gravity model of remittance flows from host $(i)$ to home country $(j)$ is expressed as,

$$
\begin{aligned}
\ln \left(R E M_{i j t}\right)= & \alpha_{0}+\alpha_{1} \ln \left(G D P_{i t}\right)+\alpha_{2} \ln \left(G D P_{j}\right) \\
& +\alpha_{3} \ln \left(D I S T_{i j}\right)+\alpha_{4} \ln \left(\text { MigStock }_{i j t}\right)+\alpha_{5}\left(\text { BilExc }_{i j t}\right)+\mu_{i} \\
& +\varepsilon_{i j t}
\end{aligned}
$$

In our baseline specification, bilateral remittances (in natural logarithms) between the host country $i$ and the home country $j$ at time $t\left(R E M_{i j t}\right)$ are related to GDPs in the host and home countries, geographical distance, migrants stock, and bilateral exchange rate. $R E M_{i j t}$ comprises funds classified as workers' remittances, compensation of employees, and migrant transfers.

The explanatory variables $G D P_{i t}$ and $G D P_{j}$ stand for the real gross domestic products for the host country $(i)$ and home country $(j)$ in period $t$, and $D I S T_{i j}$ is the physical distance between the capitals of the home and the host country. BilExc $i j t$ is the bilateral exchange rate denominated in home country currency and MigStock $k_{i j t}$ denotes the stock of migrants from $j$ that live in country $i$ at time $t$. Finally, $\mu_{i}$ denotes the host-country specific effects that control for unobservable heterogeneity. The last term $\varepsilon_{i j t}$ denotes the error term. 
The baseline model is augmented with additional host and home country characteristics that influence remittances.

$\ln \left(R E M_{i j t}\right)=$

$\alpha_{0}+\alpha_{1} \ln \left(G D P_{i t}\right)+\alpha_{2} \ln \left(G D P_{j}\right)+\alpha_{3} \ln \left(D I S T_{i j}\right)+$

$+\alpha_{4} \ln \left(\right.$ BilExc $\left._{i j t}\right)+\alpha_{5} \ln \left(\right.$ MigStock $\left._{i j t}\right)+\sum_{K=1}^{K} \alpha_{k} Z_{i j k t}+\mu_{i}+\varepsilon_{i j t}$

In the first extension of the model, the other controls are introduced as additional regressors $Z_{i j t}$ referring to the vector of all control variables that relate to both countries and either the host or home country. This includes domestic credit to the private sector (as a percent of GDP) in country $i$ and $j$. Similarly, the political stability in country $j$ is included to measure political uncertainty prevailing in the home country. Moreover, proxies for common official language and common religion are also included in the model in order to measure the cultural similarity between $i$ and $j$.

In the next specification, the log of transaction costs is introduced and physical distance is excluded, in order to estimate the impact of the cost on remittances to the home country.

$$
\begin{aligned}
& \ln \left(R E M_{i j t}\right)=\alpha_{0}+\alpha_{1} \ln \left(G D P_{i t}\right)+\alpha_{2} \ln \left(G D P_{j}\right)+\alpha_{3} \ln \left(\text { Remcost }_{i j t}\right)+\alpha_{4} \ln \left(\text { BilExc }_{i j t}\right)+ \\
& \sum_{K=1}^{K} \alpha_{k} Z_{i j k t}+\mu_{i}+\varepsilon_{i j t}
\end{aligned}
$$

Remcost $_{i j t}$ is the transaction cost of sending remittances from the host country to the home country. Since some variables are in natural logs (except dummies, exchange rate, financial development and exchange rate variable), the estimated coefficients can be interpret as elasticities.

\subsubsection{Data and variable definitions}

We collected data on remittances from 23 host countries to Pakistan. These countries account for about 90 percent of remittance flows to Pakistan during the examined period (see Table 3.1). The selection of countries depends on the availability of bilateral remittances data. For factors explaining bilateral flows, we use both country-specific and bilateral variables taken from different sources. In particular, bilateral remittances in USD millions come from the SBP. The limitation of the reported data is that they most likely underestimate the volume of remittances 
sent through informal channels (hawala or hundi). Data on informal remittance flows are indeed patchy and do not permit the construction of time series with any degree of reliability. A few estimates of informal flows exist for specific points in time and for specific remittance corridors. For example, Arif (2009) points out that more than half of the remittances sent to Pakistan from the Persian Gulf come through informal channels. This notwithstanding, the study is concerned with the effect of transaction costs on the amount of formal remittances received, for which officially available data of acceptable quality are used.

In what follows, we describe the variables that are considered important factors in influencing remittance flows. The GDP for the host country in billions of USD comes from WDI and is the most obvious factor that influences higher remittances to home countries (Vargas and Huang, 2006). The second explaining factor is the income level (measured in term of GDP) in the home country, which has an ambiguous effect on remittances depending on the prevailing motive to remit. The migrants stock in the destination country is also considered a crucial factor in determining remittance volumes (Freund and Spatafora, 2005). The data of Pakistani migrants stock in the host countries are taken from the Bureau of Immigration and Overseas Employment (BIOE, 2013) and from the Organisation for Economic Co-operation and Development (OECD, 2013). For North America, Europe, and the Asia-Pacific region, where labor receiving countries are located, we use the OECD database for two main reasons. Firstly, the BIOE dataset only contains legal outflow per year of workers looking for employment, thus excluding migratory movements for education, family union as well as illegal migrants (Amjad et. al, 2012). Secondly, it does not track returning workers, which makes it impossible to accurately estimate the country's migrant stock. We estimate the stock of migrants for Middle Eastern countries using the BIOE dataset assuming that the returning workers represent around 4 percent of the total migrant stock. This figure is based on Iqbal and Khan (1981), who computed the share of returning migrants to be 3.4 percent of the Pakistani migrants stock in the Middle East. Geographical distance is measured as the distance from Islamabad, Pakistan's capital, to the corresponding capital of the remittances-sending country. The variable comes from the CEPII database. The transaction cost variable is estimated using data from the World Bank Remittances Prices Worldwide for major sending corridors to Pakistan (World Bank. 2014b). To obtain data for each destination and time period, we formulate two assumptions. First, we assume that transaction costs of sending remittances from the UAE to Pakistan are similar to that of the 
neighboring countries Oman, Kuwait and Qatar. Similarly, the remittances cost from the US is also used for Canada. Moreover, the cost of remittances from Norway to Pakistan has been used to proxy for the cost from Germany, France, Italy, Sweden, Denmark, Greece and Switzerland. Secondly, we assume that the costs of remittances are determined by migrants stock in the remittance-host country as well as the financial development in both the home and host countries. Data for cost of remitting are available only for the years 2010 to 2013 . We use data from these four year to estimate the transaction cost for each sending country by regressing the cost of remitting on migrants stock in the remittance-host country and financial development in both home and host countries as well as extrapolating the resulting predicted values for the missing time period (2001-2009) ${ }^{19}$

The study uses real exchange rate is computed as the nominal exchange rate times the relative price of the respective countries and is also an important determinant of remittances (Dakila $\&$ Claveria, 2007). The bilateral exchange rate of the PKR is obtained from DataStream. The relationship between remittances and the exchange rate is a priori ambiguous. Remittances could decrease or increase with home country currency depreciation depending on the motive to remit.

With respect to the financial sector development for home and host countries, we use domestic credit to the private sector as a percent of GDP. The data come from the WDI. Financial development is another important factor that makes remittances easier and cheaper, hence stimulating the flows via official channels (Freund and Spatafora, 2008; Singh et al., 2011). We therefore expect that the overall financial-sector development might lead to greater availability and lower costs for remittance services.

As a proxy for institutional quality of the home country, we use a political stability indicator from the World Governance Indicators from the World Bank. The improved political situation may encourage remittances, since such an environment favors investment (Singh, et.al 2011). On the other hand, weak institution may also encourage remittances to compensate for the loss of purchasing power of the family back home. Fragile institutions in the country are among the main reasons behind the decision to emigrate (Collier et.al, 2011).

\footnotetext{
${ }^{19}$ The predictions were estimated with OLS regression with a linear trend.
} 
It has also been argued that common language and religious ties tend to affect the choice of destination countries. For instance, larger shares of Pakistan's migrants reside in the Middle East and in the countries with a similar official language. We expect a positive sign for these two variables. The variables bilateral remittances, GDP (host), GDP (home) and bilateral exchange rate are at constant 2005 prices. Table 3.2 provides descriptive statistics for the above-mentioned variables.

Table 3.2. Descriptive statistics

\begin{tabular}{|c|c|c|c|c|c|}
\hline Variables and definitions & Source & Mean & S.D & Min & Max \\
\hline \multicolumn{6}{|l|}{ Dependent variable } \\
\hline $\begin{array}{l}\text { Bilateral remittances million (USD) } \\
\text { Gravity variables }\end{array}$ & State Bank of Pakistan & 177.17 & 342.34 & .024 & 1717.62 \\
\hline Host GDP in billion (USD) & WDI & $1.40 \mathrm{e}+14$ & $2.77 \mathrm{e}+14$ & $1.27 \mathrm{e}+07$ & $1.45 \mathrm{e}+15$ \\
\hline Home GDP in millions (USD) & WDI & $1.17 \mathrm{e}+11$ & $1.83 \mathrm{e}+10$ & $8.75 e+10$ & $1.47 \mathrm{e}+11$ \\
\hline Geographical distance & CEPII & 5436.47 & 2639.01 & 1801.39 & 11392.8 \\
\hline Common language & CEPII & 0.21 & 0.41 & 0 & 1 \\
\hline Transaction costs & $\begin{array}{l}\text { World Bank Remittances } \\
\text { Prices Worldwide and } \\
\text { author's calculations }\end{array}$ & 15.37 & 2.37 & 9.77 & 19.70 \\
\hline \multicolumn{6}{|l|}{ Other control variables } \\
\hline Exchange rate & DataStream & 0.14 & 0.59 & .002 & 4.45 \\
\hline $\begin{array}{l}\text { Domestic credit to private sector as } \\
\text { percent of GDP (home) }\end{array}$ & WDI & 23.30 & 4.46 & 15.65 & 28.74 \\
\hline $\begin{array}{l}\text { Domestic credit to private sector as } \\
\text { percent of GDP (host) }\end{array}$ & WDI & 104.65 & 51.44 & 27.26 & 232.10 \\
\hline Migrants stock & $\begin{array}{l}\text { BIOE, OECD, UN- } \\
\text { DESA }\end{array}$ & 0.22 & 0.53 & .003 & 3.13 \\
\hline $\begin{array}{l}\text { Institutional variables } \\
\text { Political stability (home) }\end{array}$ & $\begin{array}{l}\text { World Wide Governance } \\
\text { Indicator, World Bank }\end{array}$ & 0.16 & 0.07 & 0.10 & 0.40 \\
\hline
\end{tabular}

Note: All the variables are in levels. Period 2001-2013.

\subsubsection{Estimation issues}

A variety of empirical techniques are employed in the study. The model is first estimated using a pooled OLS as a benchmark with standard errors corrected for heteroskedasticity. However, given the panel nature of the dataset, the pooled OLS is only consistent when unobserved fixed effect and explanatory variables are uncorrelated (Wooldridge, 2002). In order to take into account the resulting unobserved heterogeneity, we use a panel data approach i.e. fixed and random effects rather than pooled OLS. Restricted F-statistics, Breuch and Pagan (1980) LM and Hausman (1978) specification tests are used in order to choose between pooled OLS vs fixed effects, pooled OLS vs random effects, and fixed vs random effects models. To choose between 
fixed and random effects, the Hausman test has been used, which indicates that the country fixed effects are correlated with the regressors, and therefore, both OLS and random effects yield biased results. The inclusion of country fixed effects in this panel study controls for sources of endogeneity related to unobservable heterogeneity that is country specific and time-invariant. The fixed effect estimator, however, does not provide a direct estimation of the coefficients of time invariant variables. One solution for this is to use the Mundlak approach (Mundlak, 1978) who proposed approximating the country specific effects as a function of the mean of time-variant variables. This is an alternative procedure to the fixed effects model, which includes averages of time-varying explanatory variables (Wooldridge, 2002), instead of using dummy variables or the within transformation. Baltagi et al. (2003) suggest using another alternative procedure, based on Hausman and Taylor (1981) when some of the regressors are endogenous. This Hausman-Taylor approach uses the means of the exogenous time-variant variables as instruments for the endogenous variables (Baum, 2006, p.229).

Finally, in order to check for the quality of our estimations, we carry out several post estimation tests. The calculation bivariate correlations between the explanatory variables help us to identify collinearity between the explanatory variables. Variables that are highly correlated are used separately or are dropped from the regression. To test for autocorrelation, the Wooldridge test is used (the null hypothesis is that there is no first order autocorrelation while the alternative hypothesis is that there is a presence of autocorrelation) the Breusch-Pagan test is used to test for heteroskedasticity.

\subsection{Empirical Findings}

In this section, we discuss our main empirical results. The benchmark estimates presented in Table 3.3 provide results for the baseline model using several estimation methods. The first column provides fixed effects estimates, the second column presents random effects estimates, the third column presents results using the Mundlak approach, and finally the fourth column presents Hausman and Taylor estimates. In the first specification, the log of remittances is regressed on the GDPs of host and home countries, geographical distance, the bilateral exchange rates, and migrants stock. Concerning the effect of economic activity in the home country on remittances, we find that the GDP of the home country has a positive and statistically significant effect on remittances (Columns 1-4 in Table 3.3). This shows that Pakistani migrants send more 
remittances when the economic conditions improve at home, which in principle supports the portfolio investment motive. This result is consistent with the findings in Kock and Sun (2011), Lueth and Arranz (2008), and Docquier et al. (2012). However, remittance flows to Pakistan do not seem to respond to the host country's economic conditions. This is in contrast to the findings of Schiopu and Siegfried, (2006), Vargas-Silva and Huang (2006) and Kemegue et al. (2011) who argue that remittances are more responsive to the host country's economic conditions than to the economic conditions of the home country. The results can be explained by considering the extent of the migrant integration into the formal sector of the host economy. It could also be due to the loan repayment hypothesis stating that remittances are fixed loan payments made by the emigrants to the households(Vargas-Silva and Huang, 2006). It could be for these reasons that the recent economic crunch has not adversely affected remittance flows to the country.

Table 3.3. Baseline panel gravity model estimates

\begin{tabular}{|c|c|c|c|c|}
\hline VARIABLES & $\begin{array}{c}(1) \\
\text { Fixed } \\
\text { Effects }\end{array}$ & $\begin{array}{c}\text { (2) } \\
\text { Random } \\
\text { Effects }\end{array}$ & $\begin{array}{c}\text { (3) } \\
\text { Mundlak } \\
\text { Approach }\end{array}$ & $\begin{array}{c}\text { (4) } \\
\text { Hausman and } \\
\text { Taylor Approach }\end{array}$ \\
\hline GDP (host) & $\begin{array}{c}-0.014 \\
(0.015)\end{array}$ & $\begin{array}{l}-0.023 * \\
(0.013)\end{array}$ & $\begin{array}{l}-0.014 \\
(0.015)\end{array}$ & $\begin{array}{l}-0.015 \\
(0.026)\end{array}$ \\
\hline GDP (home) & $\begin{array}{c}1.205 * * \\
(0.527)\end{array}$ & $\begin{array}{c}1.690 * * * \\
(0.526)\end{array}$ & $\begin{array}{l}1.205 * * \\
(0.532)\end{array}$ & $\begin{array}{c}1.184 * * * \\
(0.340)\end{array}$ \\
\hline Migrants stock & $\begin{array}{c}1.534 * * * \\
(0.367)\end{array}$ & $\begin{array}{c}1.211 * * * \\
(0.171)\end{array}$ & $\begin{array}{c}1.534 * * * \\
(0.370)\end{array}$ & $\begin{array}{c}1.542 * * * \\
(0.167)\end{array}$ \\
\hline Geographical distance & & $\begin{array}{c}0.269 \\
(0.493)\end{array}$ & $\begin{array}{c}-0.384 \\
(1.017)\end{array}$ & $\begin{array}{c}1.090 \\
(0.813)\end{array}$ \\
\hline Common official language & & $\begin{array}{c}0.401 \\
(0.438)\end{array}$ & $\begin{array}{c}1.006 \\
(0.745)\end{array}$ & $\begin{array}{l}-0.450 \\
(0.904)\end{array}$ \\
\hline Bilateral exchange rate & $\begin{array}{c}0.472 * * * \\
(0.056)\end{array}$ & $\begin{array}{c}0.467 * * * \\
(0.068)\end{array}$ & $\begin{array}{c}0.472 * * * \\
(0.057)\end{array}$ & $\begin{array}{c}0.451 * * * \\
(0.120)\end{array}$ \\
\hline GDP (host)_average & & & $\begin{array}{l}-0.0110 \\
(0.0546)\end{array}$ & \\
\hline Migrants stock_average & & & $\begin{array}{l}-0.611 \\
(0.445)\end{array}$ & \\
\hline Exchange rate_average & & & $\begin{array}{c}-0.450^{* * *} \\
(0.149)\end{array}$ & \\
\hline $\begin{array}{l}\text { Number of observation } \\
\text { R-squared } \\
\text { Hausman test (Fixed Vs } \\
\text { Random effects) }\end{array}$ & $\begin{array}{c}299 \\
0.547 \\
\text { Prob }>\text { chi2 } \\
=0.0404\end{array}$ & $\begin{array}{c}299 \\
0.542\end{array}$ & $\begin{array}{c}299 \\
0.547\end{array}$ & 299 \\
\hline
\end{tabular}


The geographical distance is not statistically significant in any of the estimated models (see Table 3.3 and Table 3.4). The mixed results in the previous literature for geographical distance indicate that distance is not always an important driver of remittance flows. The estimated results corroborate the graphical illustration in Figure 3.2 indicating that the cost of transferring money to Pakistan is unrelated with geographical distance. Another possible interpretation of why distance is a poor proxy for remittance costs is that the cost of sending money from a developed to a developing country is significantly lower than the cost of remitting in the opposite direction, whereas distance is the same. Evidence shows that remittance cost is high in the same bilateral corridor depending on the direction of the flow (Ratha and Shaw, 2007). As a result, the cost of remitting money is more related to technological developments and increased competition in the financial-services than geographical distance. In regard to the effects of migrants stock on remittances, our results expectedly show that remittances depend positively and significantly on migrants stock. This means that countries with an increasing size of migrants stock attract a higher volume of remittances (Freund and Spatafora, 2008). The results are robust and consistent with our expectations. Concerning the exchange rate variable, our findings indicate that it has a positive effect on remittances. This suggests that in case of appreciation of the home currency, migrants tend to send more money in foreign currency to insure the same amount of income in the domestic currency. Another possibility could be that migrants send more remittances in order to keep the same utility level of their family compared with their own personal utility level.

Now, we turn to the extended estimated model that includes other important control variables that are likely to have an impact on remittance flows, namely, domestic credit to the private sector as a percent of GDP for host and home countries and political stability for the home country. The results for the augmented model are presented in Table $3.4^{20}$. The inclusion of all the other control variables does alter the magnitude and significance of GDP (home) in some of the estimated models.

We also take into account the financial sector development (the driving factor of transfer cost) for both host and home country. As expected, remittances are positively and significantly related to financial sector development. The findings reveal that better financial development in the host

\footnotetext{
${ }^{20}$ The correlation matrix of the variables indicates that common religion and geographical distance are highly correlated. We dropped common religion as this might affect the direction and significance of the effect of other variables on the dependent variable.
} 
and home countries turn into higher flows of remittances. In addition, financial improvement in the home country would enhance the availability of low cost remittance services that could then direct large amount of remittances through official channels (Freund and Spatafora, 2008; and Wahba, 1991).

Table 3.4. Augmented semi-gravity model

\begin{tabular}{|c|c|c|c|c|}
\hline VARIABLES & $\begin{array}{c}(1) \\
\text { Fixed } \\
\text { Effects }\end{array}$ & $\begin{array}{c}\text { (2) } \\
\text { Random } \\
\text { Effects }\end{array}$ & $\begin{array}{c}\text { (3) } \\
\text { Mundlak } \\
\text { Approach }\end{array}$ & $\begin{array}{c}\text { (4) } \\
\text { Hausman and } \\
\text { Taylor Approach }\end{array}$ \\
\hline GDP (host) & $\begin{array}{c}0.013 \\
(0.010)\end{array}$ & $\begin{array}{c}0.001 \\
(0.012)\end{array}$ & $\begin{array}{c}0.013 \\
(0.010)\end{array}$ & $\begin{array}{c}0.012 \\
(0.023)\end{array}$ \\
\hline GDP (home) & $\begin{array}{c}0.618 \\
(0.623)\end{array}$ & $\begin{array}{c}0.903 * \\
(0.514)\end{array}$ & $\begin{array}{c}0.618 \\
(0.629)\end{array}$ & $\begin{array}{l}0.601 * \\
(0.341)\end{array}$ \\
\hline Migrants stock & $\begin{array}{c}1.377 * * * \\
(0.321)\end{array}$ & $\begin{array}{c}1.236 * * * \\
(0.178)\end{array}$ & $\begin{array}{c}1.377 * * * \\
(0.324)\end{array}$ & $\begin{array}{c}1.466^{* * *} \\
(0.144)\end{array}$ \\
\hline Geographical distance & & $\begin{array}{l}-0.626 \\
(0.783)\end{array}$ & $\begin{array}{l}-0.426 \\
(0.950)\end{array}$ & $\begin{array}{c}-0.091 \\
(0.768)\end{array}$ \\
\hline Common official language & & $\begin{array}{c}0.641 \\
(0.683)\end{array}$ & $\begin{array}{c}1.108 \\
(0.776)\end{array}$ & $\begin{array}{c}0.063 \\
(0.838)\end{array}$ \\
\hline Bilateral exchange rate & $\begin{array}{c}0.356 * * * \\
(0.058)\end{array}$ & $\begin{array}{c}0.365 * * * \\
(0.053)\end{array}$ & $\begin{array}{c}0.346 * * * \\
(0.059)\end{array}$ & $\begin{array}{c}0.348 * * * \\
(0.108)\end{array}$ \\
\hline Credit to private sector (host) & $\begin{array}{c}0.013 * * \\
(0.006)\end{array}$ & $\begin{array}{c}0.012 * * \\
(0.005)\end{array}$ & $\begin{array}{c}0.013 * * \\
(0.006)\end{array}$ & $\begin{array}{c}0.012 * * * \\
(0.002)\end{array}$ \\
\hline Credit to private sector (home) & $\begin{array}{c}0.040 * * * \\
(0.010)\end{array}$ & $\begin{array}{c}0.039 * * * \\
(0.010)\end{array}$ & $\begin{array}{c}0.040 * * * \\
(0.010)\end{array}$ & $\begin{array}{c}0.041 * * * \\
(0.012)\end{array}$ \\
\hline Political stability (home) & $\begin{array}{c}-1.293 * * \\
(0.547)\end{array}$ & $\begin{array}{c}-1.326 * * \\
(0.530)\end{array}$ & $\begin{array}{c}-1.293 * * \\
(0.553)\end{array}$ & $\begin{array}{c}-1.251 * * * \\
(0.484)\end{array}$ \\
\hline GDP (host)_average & & & $\begin{array}{c}-0.0261 \\
(0.0591)\end{array}$ & \\
\hline Migrants stock_average & & & $\begin{array}{l}-0.508 \\
(0.411)\end{array}$ & \\
\hline Exchange rate_average & & & $\begin{array}{c}-0.382 * * \\
(0.177)\end{array}$ & \\
\hline Credit to priv. sec. (host)_avg & & & $\begin{array}{l}-0.0164 * \\
(0.00951)\end{array}$ & \\
\hline Observations & 299 & 299 & 299 & 299 \\
\hline R-squared & 0.647 & 0.646 & 0.647 & \\
\hline $\begin{array}{l}\text { Hausman test (Fixed Vs } \\
\text { Random effects) }\end{array}$ & $\begin{array}{c}\text { Prob }>\text { chi } 2= \\
0.0449\end{array}$ & & & \\
\hline
\end{tabular}

Countries with improved financial markets thus have more opportunities to attract remittances through formal channels and are thereby more likely to channel it into more productive uses. 
The coefficient of the political stability variable representing institutional quality in the home country is negative and significant, implying that an unstable political environment (associated with lower growth) may encourage larger amounts of remittances. This result supports the notion that the altruistic behavior of the migrant encourages sending more remittances when the earning prospects of the migrants home country income decreases, in order to assure the same level of satisfaction $^{21}$. Similarly, the money transfer could also increase by higher outflows of emigrants to other economically well-off destinations due to political turmoil at home. This stabilization role of remittances to compensate for the loss of purchasing power due to political instability indicates that remittances are used to hedge against political disorder.

Finally, Table 3.5 reports the estimates of equation (3.4), which includes the transaction cost variable and drops geographical distance (it was not statistically significant). Financial development and migrants stock are not included because they were used to predict the transaction cost variable. Nevertheless, as robustness we use a variety of models to estimate transaction cost, which include different explanatory variables (also financial development and migrants stocks) and the main results are robust to changes in the specification and remain practically unchanged. We also run regression using the shorter series of original data on transaction costs and the results indicate a weaker relationship in some of the estimated models due to smaller variation in the data. The only exception is the Pakistan remittances initiative dummy whose association turns significant (see Table A3.7).

We found that high transaction costs significantly reduce remittances regardless of the estimation method used. For instance, a one percent decrease in the transaction cost would yield about 3 percent increase in remittances flows.

It is consistent with the notion that higher transfer costs discourages remitters or pushes them into the informal sector. This seems to suggest that higher transfer costs deter transferring money back home. As discussed, variation in transfer costs has a large impact on remittances. This result is consistent with the two hypotheses. Firstly, migrants remit less in the presence of high transaction costs. Secondly, high official remittance costs lead to migrants resorting to informal remittance channels.

\footnotetext{
${ }^{21}$ In unpredictable political situations, the cost of capital would increase and consequently, investors will look for more stable investment destinations. Therefore, political instability deters economic growth (Aisen and Veiga, 2013).
} 
Table 3.5. Remittances explained with transaction cost

\begin{tabular}{|c|c|c|c|c|}
\hline VARIABLES & $\begin{array}{c}\text { (1) } \\
\text { Fixed Effects }\end{array}$ & $\begin{array}{c}\text { (2) } \\
\text { Random } \\
\text { Effects }\end{array}$ & $\begin{array}{c}\text { (3) } \\
\text { Mundlak } \\
\text { Approach }\end{array}$ & $\begin{array}{c}\text { (4) } \\
\text { Hausman and } \\
\text { Taylor Approach }\end{array}$ \\
\hline GDP (host) & $\begin{array}{c}0.002 \\
(0.014)\end{array}$ & $\begin{array}{l}-0.021 \\
(0.020)\end{array}$ & $\begin{array}{c}0.002 \\
(0.014)\end{array}$ & $\begin{array}{l}-0.005 \\
(0.027)\end{array}$ \\
\hline GDP (home) & $\begin{array}{c}2.472 * * * \\
(0.722)\end{array}$ & $\begin{array}{c}2.544 * * * \\
(0.696)\end{array}$ & $\begin{array}{c}2.472 * * * \\
(0.727)\end{array}$ & $\begin{array}{c}2.516 * * * \\
(0.401)\end{array}$ \\
\hline Common language & & $\begin{array}{c}0.816 \\
(1.076)\end{array}$ & $\begin{array}{c}1.024 \\
(1.118)\end{array}$ & $\begin{array}{c}0.754 \\
(1.063)\end{array}$ \\
\hline Transaction cost & $\begin{array}{l}-3.321 * \\
(1.911)\end{array}$ & $\begin{array}{l}-3.140 * \\
(1.807)\end{array}$ & $\begin{array}{l}-3.321 * \\
(1.924)\end{array}$ & $\begin{array}{c}-3.175^{* * *} \\
(0.679)\end{array}$ \\
\hline PRI_dummy & $\begin{array}{l}-0.150 \\
(0.105)\end{array}$ & $\begin{array}{c}-0.146 \\
(0.103)\end{array}$ & $\begin{array}{l}-0.150 \\
(0.106)\end{array}$ & $\begin{array}{l}-0.151 \\
(0.119)\end{array}$ \\
\hline Bilateral exchange rate & $\begin{array}{c}0.467 * * * \\
(0.078)\end{array}$ & $\begin{array}{c}0.443 * * * \\
(0.074)\end{array}$ & $\begin{array}{c}0.467 * * * \\
(0.078)\end{array}$ & $\begin{array}{c}0.443 * * * \\
(0.132)\end{array}$ \\
\hline Political stability (home) & $\begin{array}{c}-2.014 * * * \\
(0.473)\end{array}$ & $\begin{array}{c}-2.003 * * * \\
(0.468)\end{array}$ & $\begin{array}{c}-2.014 * * * \\
(0.476)\end{array}$ & $\begin{array}{c}-2.008 * * * \\
(0.565)\end{array}$ \\
\hline GDP (host)_avg & & & $\begin{array}{c}-0.223 * * * \\
(0.058)\end{array}$ & \\
\hline Exchange rate_avg & & & $\begin{array}{c}-1.031 * * * * \\
(0.360)\end{array}$ & \\
\hline Transaction cost_avg & & & $\begin{array}{c}-2.392 \\
(4.567)\end{array}$ & \\
\hline Observations & 299 & 299 & 299 & 299 \\
\hline $\begin{array}{l}\text { R-squared } \\
\text { Hausman test (Fixed Vs Random } \\
\text { effects) }\end{array}$ & $\begin{array}{c}0.483 \\
\text { Prob }>\text { chi } 2= \\
0.051\end{array}$ & 0.481 & 0.483 & \\
\hline Number of destination & 23 & 23 & 23 & 23 \\
\hline
\end{tabular}

Finally, in order to investigate whether the Pakistani initiatives to favor remittances send through formal channels have had an effect on the amount of remittances sent to Pakistan. Accordingly, we include the relevant time dummies to check whether there is a significant difference before and after the initiatives in the amount of remittances sent through formal channels. We include PRI_dummy (Pakistan Remittances Initiatives and National Cash Remittance Program), which takes the value of one from 2011 onwards, zero otherwise. The coefficients of these dummy variables are not statistically significant, as shown in the Tables 3.5. This could be due to a number of reasons. Firstly, a considerable proportion of immigrants from Pakistan (more than 60 percent) reside in the Middle East. Those are mainly low-wage workers, often illiterate or with a 
low level of education, who probably find the formal banking channel's documentary requirements daunting. Secondly, the effects of a new policy take time to become visible in the statistics. Thirdly, The presence of formal banking institutions in the rural areas is thin. And finally, evidence found in Ahmed and Mughal (2015) shows that most work-related migration from the country is that of working-age males, in whose absence social customs do not encourage unaccompanied long-distance travel of women needed to go to a financial institution. Hence, informal money transfer channels provide at the doorstep delivery services to cater for these households' requirements, in particular for women living in remote areas that are unable to go to financial institutions not found nearby.

\subsection{Concluding Remarks}

This paper explores the relative importance of the determinants that drive the volume of remittance flows to Pakistan with a particular focus on transaction costs. With this aim, we estimate a gravity model using bilateral remittances data for 23 major remittance-sending countries during the period 2001-2013 and apply a variety of panel data estimation techniques to tackle several econometric issues.

According to our findings, recorded remittance flows rise with the country's stock of migrants residing abroad. Similarly, our findings indicate that differences in the financial system and variations in the bilateral exchange rate strongly influence the size of remittance flows to Pakistan. More importantly, decreases in transaction costs seems to foster remittances, suggesting that when the cost on remitting increases, migrants either refrain from sending money home or use informal channels to remit (hundi or hawala, by hand, through friends, etc). In contrast, no significant effect of geographical distance could be identified. This indicates that geographical distance is not a good proxy for the cost of remitting. This shows that the latter can be better understood in terms of migrant networks and improvements in home and host country financial services.

These empirical findings indicate that policies that aim to facilitate remittances should focus on reducing the transaction cost of sending money. Transaction costs can be lowered by increasing access to financial services in the remote areas through innovations such as branchless banking. The reduction of costs will not only increase the volume of remittances but will enhance financial inclusion. The improved financial services will redirect these flows from informal to formal 
channels in the medium term that will eventually open new door for easing these flows as an important finance source for developing countries. 


\section{References}

Aisen, A., \& Veiga, F. J. (2013). How does political instability affect economic growth? European Journal of Political Economy, 29, 151-167.

Ahmed, J and Zarzoso, I.M (2013). Blessing or Curse: The stabilizing role of remittances, foreign aid and FDI to Pakistan. May 2013, discussion papers, Center for European Governance and Economic Development Research, No. 153

Al-Mashat, R., \& Billmeier, A. (2012). Push or pull? The determinants of remittances to Egypt, Review of Middle East Economics and Finance, 8(2)

Anderson, J. E. (1979). A theoretical foundation for the gravity equation. American economic review, 69(1), 106-116.

Anderson, James E., and Eric van Wincoop. (2003). Gravity with gravitas: A solution to the border puzzle. American Economic Review, 93(1): 170-192.

Amjad, R., Irfan, M. \& Arif, G. M. (2013). How to increase formal inflows of remittances: An analysis of the remittance market in Pakistan, International Growth Center, WP, 2013

Amjad, R., Arif, G. M., \& Irfan, M. (2012). Preliminary study: Explaining the ten-fold increase in remittances to Pakistan 2001-2012. Working papers \& research reports, 2012.

Arif, G. M. (2009). Economic and social impacts of remittances on households': The case of Pakistani migrants working in Saudi Arabia. Pakistan Institute of Development Economics.

Baltagi, B. H., Bresson, G., \& Pirotte, A. (2003). Fixed effects, random effects or HausmanTaylor?: A pretest estimator. Economics letters, 79(3), 361-369

Baum, C. F. (2006). An introduction to modern econometrics using Stata. Stata Press.

Beck, T., \& Pería, M. S. M. (2011). What explains the price of remittances? An examination across 119 country corridors. The World Bank Economic Review, lhr017.

Bergstrand, J. H. (1989). The generalized gravity equation, monopolistic competition, and the factor-proportions theory in international trade. Review of Economics and statistics, 71(1), $143-153$.

Borjas, G. J. (1999). The economic analysis of immigration. Handbook of labor economics, 3, $1697-1760$.

Bouhga-Hagbe, J. (2006). Altruism and workers' remittances: Evidence from selected countries in the Middle East and central Asia (No. 06/130). International Monetary Fund. 
Bénassy-Quéré, A., Coupet, M., \& Mayer, T. (2007). Institutional determinants of foreign direct investment. The World Economy, 30(5), 764-782.

Bureau of Emigration and Overseas Employment (BE\&OE), Labor and manpower division, Government of Pakistan

Breusch, T. S., \& Pagan, A. R. (1980). The Lagrange multiplier test and its applications to model specification in econometrics. The Review of Economic Studies, 239-253.

Collier, W., Piracha, M., \& Randazzo, T. (2011). Remittances and return migration (No. 6091). Discussion Paper series, IZA

Dakila, F., \& Claveria, R. (2007). Identifying the determinants of overseas Filipinos' remittances: Which exchange rate measure is most relevant? Center for Monetary and Financial Policy. BSP Working Paper Series, (2007-02).

De Sousa, J., \& Duval, L. (2010). Geographic distance and remittances in Romania: Out of sight, out of mind? International Economics, 121, 81-97.

Demekas, D. G., Horváth, B., Ribakova, E., \& Wu, Y. (2005). Foreign direct investment in Southeastern Europe: how (and how much) can policies help? IMF Working Paper $05 / 110$.

Docquier, F., Rapoport, H., \& Salomone, S. (2012). Remittances, migrants education and immigration policy: Theory and evidence from bilateral data. Regional Science and Urban Economics, 42(5), 817-828.

Frankel, J. (2011). Are bilateral remittances countercyclical? Open Economies Review, 22(1), 116.

Feenstra, R. C., Markusen, J. R., \& Rose, A. K. (2001). Using the gravity equation to differentiate among alternative theories of trade. Canadian Journal of Economics/Revue canadienne d'économique, 34(2), 430-447.

Freund, C., \& Spatafora, N. (2008). Remittances, transaction costs, and informality. Journal of Development Economics, 86(2), 356-366.

Gibson, J., McKenzie, D., \& Rohorua, H. (2006). How cost elastic are remittances? Estimates from Tongan migrants in New Zealand. University of Waikato, Department of Economics.

Hattari, R., \& Rajan, R. S. (2008). Sources of FDI flows to developing Asia: The roles of distance and time zones (No. 117). ADBI working paper series.

Hausman, J. A. (1978). Specification tests in econometrics. Econometrica: Journal of the Econometric Society, 1251-1271. 
Hausman, J. A., \& Taylor, W. E. (1981). Panel data and unobservable individual effects. Econometrica: Journal of the Econometric Society, 1377-1398.

Iqbal, M., \& Khan, M. F. (1981). Economic implications of the return flow of immigrants from the Middle East: a preliminary study. PIDE, Research Reports No. 132.

Irfan, M (1999). Emigration from Pakistan-1947-97 (No. 38623). University Library of Munich, Germany.

Karemera, D., Oguledo, V. I., \& Davis, B. (2000). A gravity model analysis of international migration to North America. Applied Economics, 32(13), 1745-1755.

Kemegue, F., Owusu-Sekyere, E., \& van Eyden, R. (2011). What drives remittance inflows to Sub-Saharan Africa? A dynamic panel approach. Unpublished manuscript.

Kock, U., \& Sun, Y. (2011). Remittances in Pakistan: Why have they gone up, and why aren't they coming down? International Monetary Fund.

Lewer, J. J., \& Van den Berg, H. (2008). A gravity model of immigration. Economics letters, 99(1), 164-167.

Lueth, E., \& Ruiz-Arranz, M. (2008). Determinants of bilateral remittance flows. The BE Journal of Macroeconomics, 8(1).

Mayda, A. M. (2010). International migration: A panel data analysis of the determinants of bilateral flows. Journal of Population Economics, 23(4), 1249-1274.

Mayer, T., \& Zignago, S. (2011). Notes on CEPII's distances measures: The GeoDist database.

Ministry of Finance, (2013). Pakistan Economic survey 2012-13. Government of Pakistan, Islamabad.

Mundlak, Y. (1978). On the pooling of time series and cross section data. Econometrica, 46(1), 69-85.

Mughal, M.Y. and Makhlouf, F. (2011). Volatility of remittances to Pakistan: What do the data tell?, Economics Bulletin, 31 (1), 605-612.

OECD (2013). International migration database. OECD Publishing

Oak, C (2013). Innovations in the Middle-East to Pakistan remittance corridors, Shift thought.

Orozco, M. (2003) Worker remittances in the international scope. Inter- American Dialogue Working Paper, commissioned by the Multilateral Investment Fund. 
Özden, Ç., \& Schiff, M. W. (Eds.). (2006). International migration, remittances, and the brain drain. World Bank Publications.

Portes, R., \& Rey, H. (2005). The determinants of cross-border equity flows. Journal of international Economics, 65(2), 269-296.

Rapoport, H., \& Docquier, F. (2006). The economics of migrants' remittances. Handbook of the economics of giving, altruism and reciprocity, 2, 1135-1198.

Ratha, D \& Shaw, W (2007). South-South migration and remittances, World Bank, Washington

Schiopu, I., \& Siegfried, N. (2006). Determinants of workers' remittances: Evidence from the European neighbouring region (No. 688). European Central Bank.

Singh, R. J., Haacker, M., Lee, K. W., \& Le Goff, M. (2011). Determinants and macroeconomic impact of remittances in Sub-Saharan Africa. Journal of African Economies, 20(2), 312340.

Sander, C. (2004). Capturing a market share? Migrant remittances and money transfers as a microfinance service in Sub-Saharan Africa. Small enterprise development, 15(1), 20-34.

Stark, O., \& Taylor, J. E. (1991). Migration incentives, migration types: The role of relative deprivation. The Economic Journal, 1163-1178.

State Bank of Pakistan (2012). Annual Performance review, 2011-12.

State Bank of Pakistan (2014). Country-wise workers' remittances http://www.sbp.org.pk/stats/survey/index.asp

Vargas-Silva, C., \& Huang, P. (2006). Macroeconomic determinants of workers' remittances: Host versus home country's economic conditions. Journal of International Trade \& Economic Development, 15(1), 81-99.

United Nations (2014). Trends in international migrants stock, Department of Economic and Social Affairs

UNCTAD (2013). UNCTADstat. New York: United Nations.

Wahba, S. (1991). What determines workers' remittances? Finance and Development 28 (4), 4144

Wooldridge, J. M. (2002). Econometric analysis of cross section and panel data. MIT press.

Woodruff, C., \& Zenteno, R. (2001). Remittances and microenterprises in Mexico. UCSD, Graduate School of International Relations and Pacific Studies Working Paper.

WDI (2013). World Development Indicators. Online Database, World Bank. 
World Bank. (2014a). Migration and development brief 22. Washington, DC: Migration and Remittances Unit, Development Prospects Group

World Bank. (2014b). Remittance prices worldwide: Making markets more transparent 


\section{Appendix}

Table A3.6. Correlations matrix

\begin{tabular}{|l|llllllllll}
\hline \multicolumn{1}{l}{1} & 2 & 3 & 4 & 5 & 6 & 7 & 8 & 9 & 10 \\
\hline 1 & 1 & & & & & & & & & \\
2 & 0.05 & 1 & & & & & & & & \\
3 & -0.23 & 0.13 & 1 & & & & & & & \\
4 & 0.73 & 0.00 & -0.41 & 1 & & & & & & \\
5 & 0.28 & 0.00 & 0.13 & 0.62 & 1 & & & & & \\
6 & 0.15 & -0.12 & -0.16 & 0.07 & -0.10 & 1 & & & & \\
7 & 0.45 & 0.24 & -0.48 & 0.53 & 0.22 & -0.03 & 1 & & & \\
8 & -0.05 & -0.41 & -0.07 & -0.00 & -0.00 & 0.07 & -0.08 & 1 & & \\
9 & -0.01 & -0.32 & -0.05 & 0.00 & 0.00 & 0.03 & -0.07 & -0.11 & 1 & \\
10 & -0.76 & 0.00 & 0.65 & -0.88 & -0.31 & -0.10 & -0.73 & 0.00 & 0.00 & 1 \\
\hline
\end{tabular}

Note: Number of observations: 299. 1. GDP (host). 2. GDP (home). 3. Migrants Stock. 4. Geographical distance. 5. Common language (official) 6. Bilateral exchange rate 7. Domestic credit to private sector (host) 8. Domestic credit to private sector (home) 9. Political stability (home) 10 . Common religion.

Table A3.7. Remittances and transaction cost

\begin{tabular}{lcccc}
\hline VARIABLES & $\begin{array}{c}(1) \\
\text { Fixed Effects }\end{array}$ & $\begin{array}{c}(2) \\
\text { Random } \\
\text { Effects }\end{array}$ & $\begin{array}{c}(3) \\
\text { Mundlak } \\
\text { Approach }\end{array}$ & $\begin{array}{c}(4) \\
\text { Hausman and } \\
\text { Taylor } \\
\text { Approach }\end{array}$ \\
\hline GDP (host) & -0.0263 & $-0.0273^{* *}$ & -0.0248 & -0.0291 \\
& $(0.0159)$ & $(0.0135)$ & $(0.0158)$ & $(0.0195)$ \\
GDP (home) & -1.419 & $-2.036^{* *}$ & -1.395 & $-1.854^{* *}$ \\
Migrants stock & $(0.876)$ & $(0.829)$ & $(0.902)$ & $(0.769)$ \\
Transaction cost & 0.204 & $0.853^{* * *}$ & -0.0328 & $0.757^{* * *}$ \\
& $(0.381)$ & $(0.0931)$ & $(0.377)$ & $(0.201)$ \\
PRI_dummy & -0.178 & $-0.210^{*}$ & -0.246 & -0.175 \\
Common official language & $(0.173)$ & $(0.145)$ & $(0.180)$ & $(0.142)$ \\
& $0.198^{* *}$ & $0.141^{* *}$ & $0.234^{* * *}$ & $0.144^{*}$ \\
Bilateral exchange rate & $(0.0746)$ & $(0.0603)$ & $(0.0753)$ & $(0.0821)$ \\
& & $1.102^{* * *}$ & $0.962^{* * *}$ & 1.160 \\
Constant & & $(0.308)$ & $(0.338)$ & $(0.706)$ \\
& 0.114 & -0.00499 & 0.148 & 0.0379 \\
Observations & $(0.120)$ & $(0.0889)$ & $(0.120)$ & $(0.224)$ \\
R-squared & & & $(0.363)$ & \\
Number of destination & $41.79^{*}$ & $59.42^{* * *}$ & $43.31^{*}$ & $54.41^{* * *}$ \\
\hline
\end{tabular}

Note: ${ }^{* * *} \mathrm{p}<0.01,{ }^{* *} \mathrm{p}<0.05,{ }^{*} \mathrm{p}<0.1$. Robust standard errors in parenthesis. 


\title{
Chapter 4 :How Do Migrant Remittances Affect Household Consumption Patterns?
}

Joint work with Mazhar Mughal ${ }^{\dagger}$

\begin{abstract}
This study analyzes differential consumption patterns of Pakistani migrant households resulting from foreign and domestic remittances. Using the Working-Leser model and a number of matching techniques, we analyze a large representative household survey carried out in 20102011 to compare various expenditure categories of recipient and non-recipient households across different income brackets. Findings show that foreign remittances lead to significant consumption changes. Contrary to the widely-held view, remittances do not raise the budget share on consumer goods and recreation, while the allocation on education increases substantially. Households receiving domestic remittances also show a strong focus on human capital with significantly higher shares of health and education. Recipients of international transfers living below one dollar a day spend proportionally more on food compared with their non-recipient counterparts, whereas their education and health budget shares are not dissimilar. We find that migrant households perceive remittances as a mainly transient, not fully fungible source of income.
\end{abstract}

Key Words: Expenditure; Consumption patterns; International remittances; Domestic remittances; Pakistan.

JEL Codes: O12, O15

\section{Acknowledgment}

We would like to thank Prof. Stephan Klasen and the participants in the staff seminar of the development economics research group at the university of the Göttingen for their helpful comments and discussion.

\footnotetext{
${ }^{\dagger}$ Pau Business School, France.
} 


\subsection{Introduction}

Migration and the money transfers it generates has been playing an important role in the social and economic progress of the developing countries during recent decades. Migration, whether from villages to cities or from one country to another, can involve a change in consumption patterns of the migrants' households back home. This can take place in several ways. First, the money migrants remit leads to higher household income which can be differentially consumed, saved or invested. Secondly, remittances help diversify the migrant household's sources of income depending on the extent the household and migrant incomes are correlated. Thirdly, migration exposes the households to new lifestyles and consumption behaviours. These social transfers generate different patterns of food, health, education, living and recreation expenditures. These marginal consumption patterns of remittances shape the growth and developmental effects of remittances on the migrants' home economy.

If the remittances lead to higher marginal shares of food, consumer goods and other non investment expenditures, they are thought to have minimal impact on the economic development of the community. Studies such as Adams and Cuecuecha (2010a), Chami et al. (2003) and Clément (2011) support this pessimistic view of remittances. On the other hand, Acosta et al. (2007), Adams (1998), Adams and Cuecuecha (2010b), Alderman (1996), Amuedo-Dorantes and Pozo (2011), Kifle (2007) and Taylor and Mora (2006) among others suggest beneficial effects

of migrant remittances through improvements in the households' healthcare, educational attainment and higher investment in productive ventures.

According to Massey et al. (1987) and Russell et al. (1990), these beneficial investments occur once the migrant household's subsistence needs are satisfied.

The impact of remittances on the households' expenditure behaviour crucially depends on how remittances are perceived by the recipient households. If given the nature of migration and the migrant's economic status, remittances are considered part of the household's permanent income; they will be treated just as other fungible sources of income and will therefore be consumed in similar fashion (Athukorala, 1990; Cardona Sosa and Medina, 2006). However, if remittances are perceived as a temporary income arrangement, they are more likely to be saved or invested than consumed (Adams, 1998). In this study, we argue that these two hypotheses need not be 
mutually exclusive, and may co-exist depending on the nature of remittances and household characteristics. We test this proposition by using a large representative household survey dataset carried out in Pakistan in 2010-2011 to examine the impact of foreign and domestic remittances on various expenditure categories of the migrant households' annual budgets as well as their respective shares in the household budget. We find that migrant households treat remittances as a temporary source of income and invest them to increase their human capital stock. However, this behavior is altered by the households' resource availability, as poor remittance recipients prefer spending a bigger share of their budget on food rather than education or health.

The remainder of the study is organized as follows: In the next section, we overview existing literature on the consumption behaviour of remittance recipient households in developing countries. Bivariate association of foreign and internal remittances with migrant households' economic, demographic and geographical features is presented in Section 3, followed by a description of the empirical model and econometric techniques in Section 4.

Section 5 presents key findings using Ordinary Least Squares, Tobit and different matching techniques, followed by their discussion in Section 6. The penultimate section illustrates various sensitivity and robustness measures undertaken in the analysis. Section 8 concludes.

\subsection{Literature Overview}

A large body of research exists on the various uses migrant remittances are put to across the developing world, and to what extent those patterns differ from those resulting from other sources of household income. Remittances are often found to be spent mainly on consumption goods rather than saved or invested (Chami, Fullenkamp and Jahjah, 2003; Clément, 2011; Durand and Massey, 1992). Remittances are reported to be frittered away on conspicuous consumption such as consumer items symbolizing social status and ceremonies at the cost of more productive expenditures (Chandavarkar, 1980:39; Tabuga, 2007).

Findings from other studies challenge this pessimistic view. Even though the migrant household may increase its consumption spending as a result of receiving money from the migrant member of the household, the additional funds may improve the household's living conditions. Expenditure on more and better quality food leads to better nutrition and food security (Durand et al., 1996; Jimenez, 2009). 
Moreover, part of the additional income is spent on goods such as education and health. Adams and Cuecuecha (2010b) in the case of Guatemala, Cardona Sosa and Medina (2006) in the case of Columbia and Kifle (2007) in the case of Eritrea find evidence of an increased share of education spending in the household budget resulting from migrant remittances. Similarly, studies such as Amuedo-Dorantes and Pozo (2011), Cardona Sosa and Medina (2006) and Yang (2005) report proportionally higher marginal health spending by migrant households. Acosta et al. (2007) examine the household consumption patterns of seven Latin-American countries and find a general decrease in the share of food and other consumption spending and a significant increase in the share of health spending among migrant households.

Some studies indicate that remittances lead to higher budget allocations on construction and repair of houses (Adams, 1991; Arif, 2009; Osili, 2004).

In certain economies, a greater proportion of remittances are invested to expand small scale businesses, purchase of necessary capital goods and machinery and finance new ventures (Taylor and Mora, 2006).

Some studies compare the consumption patterns of international and domestic remittances. The two kinds of remittances widely differ in their usage subject to the economic and demographic profiles of the migrants and migrant households. Clément (2011) for instance finds that recipients of international remittances in Tajikistan have a higher propensity to consume than to invest, while the consumption patterns of domestic Tajik remittance recipients do not differ significantly from the non-recipient households. His findings indicate that a higher proportion of household expenditure is devoted to healthcare among domestic migrant households, whereas no increase in budgetary allocation for health, education or other productive expenditures can be traced among the recipients of foreign transfers. In contrast, Castaldo and Reilly (2007) find that the consumption pattern for Albanian households receiving internal remittances is not statistically different from those that do not receive such transfers, whereas households who receive remittances from abroad spend, on average, a lower share of expenditure on food and a higher share on consumer durables compared to households who do not receive any type of migrant remittances. In the same vein, Cuong (2009) concludes that internal remittances in Vietnam are spent more on consumption goods than international remittances. 
The differential use of remittances discussed so far depends not only on the migrant's income and the consequent choice of the amount and frequency of remittance back home, but also on the socioeconomic profile of the migrant household. Remittances can add to the savings or invested gainfully once the household's basic consumption needs have been fulfilled (Russell et al., 1990). Remittances therefore represent a short-term coping strategy that allows the dependent households to achieve a basic level of consumption. A migrant household's consumption behaviour is also driven by its perception of remittances as transitory or permanent income. In the former case, remittances are more likely to be spent on physical or human capital investments than consumed (Adams, 1998). If remittances are treated as any other source of income (permanent income hypothesis), they would be considered fungible and thus spent just like other source of household income. Migrant households' propensity to consume may then not differ in any substantial manner from the non-migrant households (Athukorala, 1990; Cardona Sosa and Medina, 2006).

A few studies have examined the observed uses of Pakistani households receiving foreign remittances. Ahmed et al. (2010), for instance, find that foreign remittance recipients have higher budget shares devoted to food, consumer items and education. Arif (2005) analyzes the 20002001 Pakistan Socioeconomic Survey (PSES) and concludes that total per capita monthly expenditures of migrant households are at least 50\% higher than the expenditures of their nonmigrant counterparts. Migrant households, on average, spend 38\% of the total expenditure on food while non migrant households spend an average of $46 \%$ on food items.

These studies, however, do not focus on the revealed consumption preferences of the Pakistani migrant households. Besides, they fail to address the potential selection bias that might arise due to unobserved individual and household characteristics. Moreover, the studies do not make a differential comparison of the two types of migrant remittances. In what follows, we contribute to the literature by addressing these limitations of the extant research.

\subsection{Data description}

This study is based on the 2010 - 2011 round of Pakistan Social and Living-Standards Measurement Survey (PSLM) carried out on 16,341 households. The PSLM is a representative country-wide survey that collects data on household income, consumption, wealth, savings, work, social and demographic features. A two-step random stratified sampling scheme is adopted 
for the purpose with the sample stratified on a province and rural/urban basis. Villages and enumeration blocks are taken as primary sample units in rural and urban areas respectively, while households in each of the 1,180 sampled villages and enumeration blocks are considered secondary sampling units.

The dataset contains data on various sources of household income. A sizeable proportion of households $(5.4 \%)$ receive foreign remittances. The corresponding share for domestic remittances is even higher at (10.7\%). Table 4.1 presents demographic, consumption, economic and locational features of foreign and domestic remittance receiving households. Households receiving international remittances appear to be significantly different from those who do not receive remittances. Recipient households are substantially larger than non-recipient households. Similarly, recipients are at an average more educated and more often located in rural areas as compare to non-recipient households. Heads of foreign remittance receiving households are older and somewhat less educated. $43 \%$ of the heads of recipient households are women as compared to $7 \%$ of the non-recipients, suggesting that many of the foreign migrants are male household heads in whose absence, women take up more household responsibilities. International migration from Pakistan is overwhelmingly male with few women going abroad for employment. Moreover, a smaller proportion of adults from recipient households works (43\%) as compared to non-recipient ones $(83 \%)$. These changes in the labour participation of the migrant household can not only be a result of migration and the ensuing remittances, but may also be a cause of remittances in the first place.

Houses of international remittance receiving households are better located, with shorter distances to public services and necessities such as drinking water, public transport, groceries and primary, middle and high schools. This suggests their relatively better economic status.

Households receiving domestic transfers likewise show some important differences with nonrecipient households (Table 4.1 Panel 2). Like foreign remittance receiving households, recipients of internal remittances are predominantly based in villages and have older and less educated heads. However, unlike foreign remittance receiving households, domestic remittance receiving households are smaller and have fewer children and working age adults than the non receiving ones. 
Table 4.1. Household Profile by Access to Remittances

\begin{tabular}{|c|c|c|c|c|c|c|}
\hline Variable & $\begin{array}{l}\text { HH with no } \\
\text { Foreign } \\
\text { Remittances }\end{array}$ & $\begin{array}{l}\text { HH with } \\
\text { Foreign } \\
\text { Remittances }\end{array}$ & $\begin{array}{l}\text { Two } \\
\text { sample T- } \\
\text { test }\end{array}$ & $\begin{array}{l}\text { HH with no } \\
\text { Domestic } \\
\text { Remittances }\end{array}$ & $\begin{array}{l}\text { HH with } \\
\text { Domestic } \\
\text { Remittances }\end{array}$ & $\begin{array}{l}\text { Two } \\
\text { sample T- } \\
\text { test } \\
\end{array}$ \\
\hline \multicolumn{7}{|l|}{$\begin{array}{l}\text { Demographic } \\
\text { indicators }\end{array}$} \\
\hline Age of head & 46.26 & 48.82 & 4.01 & 46.03 & 49.46 & 6.85 \\
\hline Household size & 6.36 & 6.82 & 2.82 & 6.45 & 5.80 & -6.03 \\
\hline Dependency ratio & 0.49 & 0.54 & 4.53 & 0.49 & 0.54 & 6.32 \\
\hline $\begin{array}{l}\text { Number of adults } \\
\text { with schooling }\end{array}$ & 1.84 & 2.25 & 5.10 & 1.89 & 1.62 & -4.86 \\
\hline Sex of head & 0.07 & 0.43 & 16.11 & 0.06 & 0.40 & 20.27 \\
\hline Education of head & 2.31 & 2.15 & -2.04 & 2.33 & 1.99 & -5.99 \\
\hline $\begin{array}{l}\text { Marital Status of } \\
\text { head }\end{array}$ & 0.90 & 0.89 & -0.50 & 0.91 & 0.81 & -7.92 \\
\hline Work status of head & 0.83 & 0.43 & -17.21 & 0.85 & 0.48 & -19.86 \\
\hline \multicolumn{7}{|l|}{$\begin{array}{l}\text { Consumption } \\
\text { indicators }\end{array}$} \\
\hline Total expenditure & 197898.10 & 296255.80 & 6.95 & 205423.20 & 185418.00 & -2.00 \\
\hline Food & 75227.02 & 103198.20 & 9.05 & 77558.46 & 70096.30 & -3.76 \\
\hline Education & 7253.35 & 15604.62 & 6.23 & 7673.72 & 8006.37 & 0.40 \\
\hline Healthcare & 6272.66 & 8656.58 & 4.50 & 6212.24 & 7985.15 & 2.84 \\
\hline $\begin{array}{l}\text { Housing and } \\
\text { Utilities }\end{array}$ & 53664.00 & 72332.95 & 5.07 & 55597.31 & 47094.50 & -4.33 \\
\hline $\begin{array}{l}\text { Consumer non- } \\
\text { durables }\end{array}$ & 20231.83 & 29039.46 & 6.70 & 1025.68 & 546.65 & -5.34 \\
\hline Recreation & 966.85 & 1102.11 & 0.76 & 20885.22 & 19288.10 & -2.26 \\
\hline Others & 29364.22 & 51038.04 & 4.36 & 31082.34 & 26116.30 & -3.51 \\
\hline Durables & 4918.16 & 15283.87 & 2.17 & 5388.17 & 6283.89 & 0.65 \\
\hline \multicolumn{7}{|l|}{ Economic } \\
\hline $\begin{array}{l}\text { Local economic } \\
\text { condition }\end{array}$ & -0.34 & 0.07 & 10.63 & -0.31 & -0.36 & -1.97 \\
\hline $\begin{array}{l}\text { Household } \\
\text { economic condition }\end{array}$ & -0.22 & -0.05 & 5.90 & -0.21 & -0.22 & -0.47 \\
\hline Asset index & 5.53 & 7.37 & 15.89 & 5.64 & 5.50 & -1.63 \\
\hline $\begin{array}{l}\text { Location } \\
\text { Indicators }\end{array}$ & & & & & & \\
\hline Region (rural/urban) & 0.35 & 0.25 & -3.86 & 0.36 & 0.19 & -10.80 \\
\hline $\begin{array}{l}\text { Province of } \\
\text { residence } \\
\text { (Punjab/others) }\end{array}$ & 0.41 & 0.37 & -1.47 & 0.43 & 0.25 & -8.66 \\
\hline
\end{tabular}

Source: Authors' calculations using PSLM (HIES) 2010-11. Note: Asset index based on Principal Component Analysis of 29 household assets. Local and household economic conditions take the values from -1 to 1 and indicate change in conditions relative to the preceding year.

Socioeconomic and geographical characteristics of internal remittance receiving and nonreceiving households often show no statistically significant difference. Household expenditure for foreign remittance receiving households is substantially higher than that of non receiving households (Rs. 296,255 vs. Rs.197,898). Spending on all budget categories is higher among 
foreign remittance receivers. For instance, expenditure on food is about $50 \%$ higher while expenditure on education and purchase of durable items is approximately $100 \%$ and $300 \%$ higher. Table 4.2 show the budget shares of various expenditure categories for households receiving foreign and domestic remittances respectively. The budget share of education and durables is substantially higher among foreign remittance receivers; while that of food is significantly lower (39\% as compared to $41 \%)$.

Table 4.2. Household Budget Shares by Access to Remittances

\begin{tabular}{lllllll}
\hline \hline $\begin{array}{l}\text { Consumption } \\
\text { indicators }\end{array}$ & $\begin{array}{l}\text { HH with no } \\
\text { Foreign } \\
\text { Remittances }\end{array}$ & $\begin{array}{l}\text { HH with } \\
\text { Foreign } \\
\text { Remittances }\end{array}$ & $\begin{array}{l}\text { Two } \\
\text { sample T- } \\
\text { test }\end{array}$ & $\begin{array}{l}\text { HH with no } \\
\text { Domestic } \\
\text { Remittances }\end{array}$ & $\begin{array}{l}\text { HH with } \\
\text { Domestic } \\
\text { Remittances }\end{array}$ & $\begin{array}{l}\text { Two } \\
\text { sample T- } \\
\text { test }\end{array}$ \\
\hline \hline Food & 41.02 & 39.04 & -3.24 & 40.99 & 40.29 & -1.29 \\
Education & 2.58 & 4.47 & 7.32 & 2.61 & 3.30 & 3.93 \\
$\begin{array}{l}\text { Health } \\
\text { Housing and }\end{array}$ & 3.39 & 3.39 & 0.00 & 3.26 & 4.47 & 6.21 \\
$\begin{array}{l}\text { Utilities } \\
\text { Recreation }\end{array}$ & 26.37 & 24.78 & -2.96 & 26.31 & 26.09 & -0.54 \\
$\begin{array}{l}\text { Consumer non- } \\
\text { durables }\end{array}$ & 0.42 & 0.32 & -3.63 & 0.43 & 0.22 & -9.78 \\
$\begin{array}{l}\text { Miscellaneous } \\
\text { Durables }\end{array}$ & 10.96 & 10.78 & -0.96 & 10.93 & 11.15 & 1.50 \\
\hline \hline
\end{tabular}

Source: Authors' calculations using PSLM (HIES) 2010-11

In contrast, total annual expenditure of internal remittance receiving households is slightly lower than that of non-recipient households (Table 4.1), showing that domestic remittances are usually sent to households belonging to lower income groups. This is also apparent in lower food, housing and recreation expenditures and higher health spending among receivers of domestic remittances. Compared to households receiving transfers from abroad, domestic remittance receivers allocate a higher share of the household budget to food, health and housing and a lower share to education expenditures (Table 4.2 Panel 2).

From the bivariate statistics shown above, an initial comparison between the households receiving the two types of transfers can be made: households receiving foreign transfers are larger and relatively more prosperous than either non foreign remittance receiving or domestic remittance receiving households They spend more on education, health and housing and have a lower budget share allocated to food despite spending more than other households. These 
descriptive statistics need to be interpreted with caution as they need to be controlled for various socioeconomic and demographic factors that distinguish the two types of households'.

\subsection{Empirical methodology}

The model estimation proceeds in two steps. First, least squares are fitted to estimate the impact of remittances on household budget shares by employing the Working Leser specification. In the second step, a set of propensity score matching (PSM) techniques is used to control for potential selection bias present in the model by matching various observable characteristics of the recipient and non-recipient households. First, the Probit model is used to calculate propensity scores. Common support is then defined and average treatment effects on the treated (ATT) are obtained using the Nearest Neighbour (NN), Radius matching and Kernel matching methods. Given that PSM is the mainstay of this study, the set of techniques is briefly described in subsection 4.2 .

\subsubsection{Model Specification}

Extant empirical literature has commonly employed the Engel curve framework to study the consumer behaviour. The approach has been applied to study the role of remittances in shaping household consumption patterns (see for instance Adams and Cuecuecha 2010b; Castaldo and Reilly, 2007; Taylor and Mora, 2006). In this framework, the quantity of a good or service consumed is taken as a function of the consumer's total expenditure and other control variables (Deaton \& Muellbauer 1999, p. 19) . The estimation of this framework therefore requires a functional form such as the Working- Leser specification (Working, 1943; Leser, 1963). The Working- Leser model relates budget share linearly to the logarithm of total expenditure (Deaton \& Muellbauer 1999, p. 19).

A change in the share of a consumption category in response to a factor such as receipt of remittances can therefore reveal the relative importance of that item in the consumption basket.

The functional form of the specification employed in this study includes various economic, socio demographic and geographical variables in addition to the household's total expenditure, and can be given as: 


$$
\omega_{i j}=C_{i} / E_{j}=\beta_{i}+\gamma_{i}\left(\log E_{j}\right)+\sum_{j} \mu_{i j} Z_{j}+\varepsilon_{i j}
$$

The resulting marginal and average budget shares for the i-th category can be derived from equation (4.1) as follows

$$
\begin{gathered}
d C_{i} / d E_{j}=\beta_{i}+\gamma_{i}\left(1+\log E_{j}\right)+\sum_{j} \mu_{i j} Z_{j}+\varepsilon_{i j} \\
A B S_{i}=C_{i} / E_{j}
\end{gathered}
$$

Our baseline model can therefore be given as:

$$
\omega_{i j}=\beta_{i}+\gamma_{i}\left(\log E_{j}\right)+\delta_{i} R_{j}+\sum_{j} \mu_{i j} Z_{j}+\varepsilon_{i j}
$$

Where $\omega_{i j}$ represents expenditure share $i$ for household $j, E$ is the logged value of total expenditure of the household $j, R_{j}$ indicates whether or not the household receives international or domestic remittances, $Z_{j}$ represents the set of household characteristics that can affect expenditure behaviour and $\varepsilon_{i j}$ is the error term. The variables included in equation (4.2) are described in subsection 4.3 .

\subsubsection{Least Squares and Tobit}

The above mentioned modified Working Leser specification is estimated by using Ordinary Least Squares, and marginal effects of foreign and internal remittances on various expenditure categories are subsequently obtained. However, these estimates are not considered reliable if there are large numbers of zero values in the dependent variable. This can happen if spending on certain items is infrequent. Some households may not purchase any durable items during a given year. Likewise, spending on some items may not be required. For example, households with no school-going children may not spend on education. For such censored datasets, Tobit is considered to be the appropriate estimation technique. This technique assumes the presence of a latent variable which is linearly associated with the set of independent variables. In this study, spending on the education, recreation and durables categories show non-negligible number of zero values. The three categories contain $34 \%, 57 \%$ and $33 \%$ zero values respectively, and are 
therefore examined using Tobit specifications. Other expenditure categories contain less than one percent zero values, and are analyzed using OLS.

\subsubsection{Propensity Score Matching (PSM)}

In the situation where the treatment group (e.g. remittance receiving households) are randomly distributed in the sample, the impact of treatment can be estimated by comparing the outcome of recipients with that of the non-recipients. However, households receiving remittances often differ from non receiving households in such important aspects as financial wherewithal, education, skills and demographic characteristics, some of which may not be observable. Regression-based estimation of remittances' impacts on expenditures may therefore be prone to selection bias in such non experimental situations. The observed outcome (called factual or post treatment outcome) needs to be compared with the outcome that would occur had the households not received remittances (counterfactual outcome).

One way of achieving this is by applying a matching algorithm. Matching methods assume the selection into treatment group to be based on the households' observable characteristics, implying that households in the treatment and non treatment groups can be matched with respect to those characteristics. However, matching requires identification of comparable groups of households with similar characteristics. This can be done using Propensity Score Matching (PSM) by constructing a summary variable for observable household characteristics, called the "propensity score” (Rosenbaum and Rubin, 1983; 1985).

PSM is essentially a weighting scheme that matches treated and non treated households by comparing the conditional probabilities of receiving remittance based on a set of covariates of the observable characteristics. The probabilities are obtained by using either the Probit or Logit models. As for both types of households, only one state (receipt or non receipt) can be observed at a given moment (Holland, 1986), therefore only average treatment effect on the treated (ATT) can be calculated as the mean effect of the paired households (Bryson, Dorsett and Purdon, 2002). Furthermore, the stable-unit-treatment-value assumption (SUTVA) has to be satisfied for all households of the subpopulation prior to ATT estimation (Rubin, 1991).

The ATT for the remittance receipt can be given as:

$A T T=E\left(C_{i 1}-C_{i 0} \mid R_{i}=1\right)$ 
Where $R_{i}=1$ refers to recipient households

Re-writing the equation:

$A T T=E\left(C_{i 1} \mid R_{i}=1\right)-E\left(C_{i 0} \mid R_{i}=1\right)$

The ATT compares the consumption of remittance receiving and non receiving households conditional on receiving remittances.

Matching methods like PSM require three important assumptions to be fulfilled for the treated and untreated households to be considered similar in term of any unobserved heterogeneity that could affect the probability of treatment assignments and the outcomes of interest. These include conditional independence, common support and balancing.

The Conditional Independence Assumption is satisfied if the potential outcomes are the same for households with identical pre-treatment observed characteristics irrespective of their treatment assignment.

$$
C_{1}, C_{0} \perp R \mid X
$$

This implies that given those characteristics, allocation to the treated group is random. Selection must therefore be exclusively based on the vector of observables which determine the propensity score (Rosenbaum \&Rubin, 1983; Caliendo \& Kopeinig, 2008).

The common support assumption implies that for each value of the observable covariates, there is a positive probability of belonging both to the beneficiary and non-beneficiary groups (Heckman, Ichimura, \& Todd, 1997).

$$
0<P(X)<1
$$

This assumption ensures that there is sufficient overlapping in the propensity scores of recipient and non-recipient households to allow sufficient matching. Therefore, only common support observations are used and unmatched observations are discarded.

The balancing assumption states that once households are matched, the characteristics of the constructed recipient and non-recipient households need to be statistically comparable.

$$
R \perp X \mid \mathrm{P}(X)
$$


In other words, given the propensity score, the observable characteristics of the recipient and non-recipient households are balanced, and the potential outcomes are independent of treatment conditional on the observed covariates.

There are several matching algorithms that can be used for matching propensity scores. These include Nearest Neighbour (NN) matching, Caliper or Radius matching, Stratification or Interval matching and kernel matching.

In this study, NN, radius and Kernel are employed to obtain matching estimates. For Kernel matching, Gaussian Kernel estimator is employed with a default bandwidth of 0.06 as well as a lower bandwidth of 0.01 to obtain more unbiased estimates. The PSM estimations are carried out using Stata's psmatch2 module (Leuven and Sianesi, 2012).

Table A4.12 and Figure A4.1 to Figure A4.4 show tests for the above mentioned assumptions. Figures A4.1 and A4.2 show density distributions for the estimated propensity scores for receiving and non-receiving households for foreign and domestic remittance recipients respectively, while Figure A4.3 to Figure A4.4 show pre- and post-matching bias reduction. The conditions of common support and balancing appear to be mostly satisfied. There is sufficient overlapping in the propensity scores of recipient and non-recipient households, as well as a substantial reduction in the median absolute standardized bias after matching. The remaining bias is less than $10 \%$ in all the estimations, lower than the $20 \%$ figure suggested by Rosenbaum and Rubin (1985). Moreover, the post-matching pseudo- $\mathrm{R}^{2}$ value is considerably lower and the likelihood ratio is insignificant, implying the absence of any systematic difference in distribution of covariates between the treated and the control groups. The characteristics of the constructed groups of recipient and non-recipient households can therefore be considered comparable.

The conditional independence assumption is tested through the Rosenbaum bounds test (Rosenbaum 2002) ${ }^{22}$. The test checks the sensitivity of the estimated results from the CIA by using the nearest neighbour matching estimates to compute the maximum and minimum p-values from the Wilcoxon sign rank test between treatment and matched pairs and the Hodges-Lehman point estimates of the impact of the treatment on the outcome variable and their respective confidence intervals. Results of the test (shown in Table A4.15 and Table A4.16) indicate that

\footnotetext{
${ }^{22}$ The findings are estimated using Stata rbounds user module (Diprete and Gangl, 2004).
} 
the odds of unobservable characteristics influencing the average treatment effects can not be satisfactorily rejected ${ }^{23}$. The assumed odd ratios for ATT sensitivity are invariably less than 2 (Table A4.15 and Table A4.16 Column 1), the critical value suggested by Duvendack and Palmer-Jones (2012). The Wilcoxon rank test p-value is greater than 0.05 in several estimations and the Hodges-Lehmann confidence interval encompasses zero.

This suggests that the assignment process is vulnerable to unobserved variables and the inferences made on the basis of these results are therefore not robust to hidden bias. Another limitation of this study is the cross-sectional nature of the survey data which does not allow analysis of time-variant aspects of household consumption and remittance dynamics. Moreover, propensity score methods can only adjust for observed confounding covariates and not for unobserved ones, meaning that selection bias arising due to unobserved variables may still affect the estimations. There is also a possibility of reverse causality between various economic indicators which the techniques may not adequately tackle. Another way in which this study would have been undertaken is to compare the two remittances recipients groups with the one receiving no remittances. However, this would lead to too little overlapping and therefore poor matching.

\subsubsection{Description of selected variables}

In the following, we describe various economic, demographic and locational variables that are employed in the multivariate estimations to examine household consumption patterns. Table 3 gives the definition and means of the variables.

\subsubsection{Consumption variables}

PSLM 2010-2011 contains detailed data on expenditures of the sampled households. These data are aggregated into eight consumption categories namely expenditure on food, education, health, housing, recreation, consumer items, durables and miscellaneous expenditures.

Consumer items include goods for personal consumption which have a life expectancy of less than one year, such as clothing, footwear, medicine etc. Durable items are consumption goods with a life expectancy of one year or more, such as furniture, fixtures, television, radio, clocks,

\footnotetext{
${ }^{23}$ The test was only carried out for ATT significantly different from zero.
} 
kitchen utensils etc. The miscellaneous category contains goods and services not included in any of the other expenditure brackets.

Different expenditure outlays have different periodicities (weekly, monthly, and yearly). These outlays are annualized to create comparable consumption categories. Table 4.4. describes the resulting eight aggregate consumption categories. These categories are used to calculate shares in annual budget for each household. Household consumption includes the value of goods and services received in kind or own produced and consumed by the household. Budget shares of all categories are alternately taken as dependent variables.

Table 4.3. Variable description

\begin{tabular}{|c|c|c|}
\hline Variable & Variable Description & Mean \\
\hline Foreign Remittances & $\begin{array}{l}\text { Dummy variable, takes the value of } 1 \text { if any member of the } \\
\text { household received remittances from abroad during last } 1 \\
\text { year, } 0 \text { otherwise }\end{array}$ & .054 \\
\hline Domestic Remittances & $\begin{array}{l}\text { Dummy variable, takes the value of } 1 \text { if any member of the } \\
\text { household received remittances inside Pakistan during last } 1 \\
\text { year, } 0 \text { otherwise }\end{array}$ & .107 \\
\hline Asset index & Index composed of various households assets & 5.63 \\
\hline Household size & Total number of family members in the household & 6.38 \\
\hline Dependency Ratio & $\begin{array}{l}\text { Share of members ages under } 18 \text { and above } 65 \text { in the } \\
\text { household }\end{array}$ & 0.50 \\
\hline Number of schooling18 & Number of adult members ever gone to school & 1.86 \\
\hline Age of head & Age of the households head in completed years & 46.3 \\
\hline Sex of head & $\begin{array}{l}\text { Dummy variable, takes the value of } 1 \text { if the household head } \\
\text { is a female, } 0 \text { otherwise }\end{array}$ & 0.09 \\
\hline Marital status of head & $\begin{array}{l}\text { Dummy variable, takes the value of } 1 \text { if the household head is } \\
\text { married, } 0 \text { otherwise }\end{array}$ & 0.92 \\
\hline Work status of head & $\begin{array}{l}\text { Dummy variable, takes the value of } 1 \text { if the household head is } \\
\text { employed, } 0 \text { otherwise }\end{array}$ & 0.81 \\
\hline Education of head & Number of years of schooling received by the household head & 2.30 \\
\hline $\begin{array}{l}\text { Household economic } \\
\text { condition }\end{array}$ & Current situation of household as compare to previous year & -0.21 \\
\hline $\begin{array}{l}\text { Local economic } \\
\text { condition }\end{array}$ & Current condition of the area as compare to previous year & -0.32 \\
\hline Region, & $\begin{array}{l}\text { Dummy variable, takes the value of } 1 \text { if the household } \\
\text { resides in rural area, } 0 \text { otherwise }\end{array}$ & 0.34 \\
\hline Province & $\begin{array}{l}\text { Takes the value of } 1 \text { if remittance recipient household lives in } \\
\text { Sindh, KPK, Baluchistan otherwise } 0\end{array}$ & 0.41 \\
\hline
\end{tabular}


Table 4.4. Description of expenditure categories

\begin{tabular}{ll}
\hline Expenditure category & Description \\
\hline Food & Milk and Milk Product, Meat Poultry and Fish, Fresh Fruits, Dry \\
& Fruits and Nuts, Vegetables, Condiments and Spices, Sugar and \\
& Honey, Non-Alcoholic Beverages, Ready-made Food, Drinks etc. \\
& Cereals, Pulses, Edible oil and Fats, Tea and Coffee, Miscellaneous \\
& Food items. \\
\hline Health & Medical care \\
\hline Housing and Utilities & $\begin{array}{l}\text { Housing rent and Housing expenses, Chinaware, Earth ware, Plastic } \\
\text { ware, and other households effects. Fuel and Lighting , }\end{array}$ \\
\hline Communication (Telephone, telegraph, internet etc ) \\
\hline Recreation & Educational and Professional stationary Supplies Expenditure. \\
\hline Consumer Non-durables & Recreation and Reading \\
& $\begin{array}{l}\text { Personal Care Services, Personal Care Articles, Household Laundry } \\
\text { cleaning and paper article, Clothing, Clothing material land services, }\end{array}$ \\
\hline Footwear and repair charges, Personal effects and Services and repair \\
charges.
\end{tabular}

Source: Authors' calculations using PSLM (HIES) 2010-11

\subsubsection{Economic indicators}

A number of economic indicators are considered as explanatory variables. These include foreign and domestic remittances, household wealth, the number of adult household members at work and the employment status of household head ${ }^{24}$.

Following Adams and Cuecuecha (2010b) and Castaldo and Reilly (2007), we take binary measures of remittances as our primary remittance indicators. This choice is motivated by the following observation: Monetary measures of remittances are prone to measurement errors as households may be unable or unwilling to precisely recall the amount received during the year prior to the survey from a household member living away from home. These measurement errors may in turn be correlated with those in household expenditure and other monetary indicators.

Household wealth has important repercussions on the expenditure indicators as wealthier households usually have higher total expenditures and spend more on education, health, housing

\footnotetext{
${ }^{24}$ The work status of female head in Pakistan does not appear to substantially correlate with the households' income levels.
} 
and other categories of consumption. Household wealth status is proxied by an asset index that consists of 29 indicators of property ownership, quality of housing and access to amenities. Principal Component Analysis (PCA) is used to obtain the first component of the assets holding index in order to explain the largest amount of information common to the constituent variables. The list of variables which constitute the asset index along with their respective scores are given in Table A4.11 in the appendix.

The income and expenditures of a household are crucially affected by whether and how many of its members work. A large household with several working members may imply a higher household income resulting in greater consumption.

Household spending on different consumption categories also depends on the incidence and extent of household poverty. Poor households need to spend proportionally more on food, health and other necessities and can spare little for education, durable items and recreation. An indicator for poverty is therefore included by taking households living below the US \$1.25 purchasing power parity poverty line as poor. This indicator of $\$ 1$ poverty is calculated by using annualized per capita adult equivalent household income. A modified OECD equivalence scale is employed assigning weights of $1,0.5$ and 0.3 to the household head, other adults and minors at home respectively. Household incomes in Rupees are converted into US Dollars by using an average exchange rate of Rs. 85.19 per US Dollar for the year 2010-2011. The corresponding household income thus calculated for the $\$ 1$ poverty line is Rupee 38869.68. Using these figures, the country's $\$ 1$ poverty rate is estimated to be $24.3 \%$ in $2010-2011$.

Household's expenditures can be significantly affected by unexpected events at home or the place of residence. Accidents, loss of job or prolonged illness of a household member particularly that of a working adult can hit the resources available for consumption. Similarly, natural catastrophes and disasters can destroy the household's capital or physical assets and damage the infrastructure in the area.

This factor that might cause a loss of revenue and lower household expenditure is taken into account by employing two subjective measures of household and local economic conditions. The measures take the values of $-1,0$ or 1 depending on whether the household or the area underwent 
a deterioration, no change, or an improvement in economic conditions compared with the situation prevailing in the preceding year.

\subsubsection{Socio-Demographic indicators}

The level of household consumption depends on the household's demographic composition (Ando and Modigliani, 1963). Household size, number of children, adults and the elderly determine the specific needs and drives household spending in different expenditure categories. A household with a higher share of dependents implies a higher propensity to consume, and consequently a lower per capita level of consumption (Adams and Cuecuecha, 2010a). Similarly, education, health and food budgets for the latter two are usually different from those of the adults. A larger household may be able to obtain economies of scale in food, housing and other expenses by sharing, transport and pooling the knowledge, space and materials involved in their production. The number of educated members in a household also influences the household's consumption patterns. Educated individuals are better aware of health and sanitary issues and spend proportionally more on education and food.

The above mentioned socio demographic factors are controlled for in the study by including variables for household size, dependency ratio and number of adults having acquired some education. Dependency ratio is defined as the share of children (less than 18 years old) and the elderly (60 years or above) in the household.

A household's spending pattern to a large extent reflects the consumption preferences and priorities of its head. An old head may prioritize health expenditure over education and housing, while a female head of household may give education and children's health a higher priority. Head's age, sex, marital and employment status and level of education are therefore important in understanding a household's consumption behaviour.

\subsubsection{Locational variables}

Differences in consumption patterns are partly due to geography: rural and more distant areas have proportionally higher transportation costs while urban areas in the developing countries usually face higher food prices. Similarly, households in agricultural provinces spend less on food and clothing. Indicators for urban - rural and province of residence are therefore included in 
the baseline model. The indicator for urban residence takes a value of one if the household resides in an urban area and zero otherwise. The categorical variable for provincial residence takes Punjab as the baseline. Punjab is the most populous province of Pakistan, accounting for $56 \%$ of the country's population. The other three provinces are Sindh, Khyber Pakhtunkhwa (KP) and Baluchistan.

\subsection{Findings}

\subsubsection{Working Leser estimations}

Table 4.5 and Table 4.6 present the results of OLS and Tobit estimations of Working Leser specifications and marginal effects for the shares of various household expenditures. The relationship between foreign remittances and expenditure is found to be statistically insignificant in five out of eight spending categories (Table 4.5). Only education, housing and utilities, and recreation spending show a significant association with foreign remittances, the latter two with a negative sign suggesting proportionally lower housing and recreation budgets among households receiving foreign remittances. Education spending among recipient households is $4.23 \%$ compared with $3.43 \%$ in non-recipient households (Table 4.6), implying a substantial $23 \%$ difference. Among other variables included in the model, most demographic variables exhibit a significant association with household expenditures. For example, larger households have a significantly higher expenditure share dedicated to food and consumer items, and lower spending on health, housing, recreation and durables. Household spending on food, health and durables increases and that on education decreases with its head's age. Likewise, the share of education spending increases with head's education as well as the number of literates at home. The gender of household heads does not play a significant role in consumption decisions. Female heads appear to spend proportionally more on education and consumer goods compared with male heads. A household with a working head spends proportionally more on food than one whose head is not at work. This may be because in a developing country such as Pakistan, only the heads of prosperous households can afford to voluntarily stay out of work, while working-age heads of low-income households generally need to work part- or full-time.

Among households' economic indicators, share of food spending decreases with household's

total spending and asset ownership. Local economic conditions also seem to affect the 
household's consumption pattern, with households' that report a better local economic situation in the area compared to the previous year spending proportionally more on nutrition.

Table 4.5. Remittances and household consumption (OLS and Tobit estimations)

\begin{tabular}{|c|c|c|c|c|c|c|c|c|}
\hline VARIABLES & Food & Health & Education & Housing & Recreation & Other & $\begin{array}{l}\text { Consumer } \\
\text { Good }\end{array}$ & Durables \\
\hline $\begin{array}{l}\text { Total } \\
\text { expenditure }\end{array}$ & $\begin{array}{l}-3.357 * * * \\
(0.657)\end{array}$ & $\begin{array}{l}0.219 \\
(0.238)\end{array}$ & $\begin{array}{l}1.687 * * *- \\
(0.287)\end{array}$ & $\begin{array}{l}-2.031^{*} \\
(1.058)\end{array}$ & $\begin{array}{l}-0.212 * * * \\
(0.030)\end{array}$ & $\begin{array}{l}4.287 * * * \\
(0.502)\end{array}$ & $\begin{array}{l}-3.477 * * * \\
(0.167)\end{array}$ & $\begin{array}{l}2.883 * * * \\
(0.397)\end{array}$ \\
\hline $\begin{array}{l}\text { Foreign } \\
\text { remittances }\end{array}$ & $\begin{array}{l}0.229 \\
(0.631)\end{array}$ & $\begin{array}{l}0.211 \\
(0.259)\end{array}$ & $\begin{array}{l}0.797 * \\
(0.419)\end{array}$ & $\begin{array}{l}-1.146^{*} \\
(0.630)\end{array}$ & $\begin{array}{l}-0.150 * * * \\
(0.038)\end{array}$ & $\begin{array}{l}-0.427 \\
(0.612)\end{array}$ & $\begin{array}{l}0.200 \\
(0.229)\end{array}$ & $\begin{array}{l}0.286 \\
(0.422)\end{array}$ \\
\hline $\begin{array}{l}\text { Domestic } \\
\text { remittances }\end{array}$ & $\begin{array}{l}-1.328 * * \\
(0.604)\end{array}$ & $\begin{array}{l}1.126 * * * \\
(0.312)\end{array}$ & $\begin{array}{l}0.483 \\
(0.302)\end{array}$ & $\begin{array}{l}-0.408 \\
(0.513)\end{array}$ & $\begin{array}{l}-0.115^{* * * *} \\
(0.032)\end{array}$ & $\begin{array}{l}-0.302 \\
(0.433)\end{array}$ & $\begin{array}{l}0.216 \\
(0.193)\end{array}$ & $\begin{array}{l}0.327 \\
(0.304)\end{array}$ \\
\hline Asset index & $\begin{array}{l}-1.104 * * * \\
(0.133)\end{array}$ & $\begin{array}{l}-0.134 * * * \\
(0.045)\end{array}$ & $\begin{array}{l}0.213 * * * \\
(0.053)\end{array}$ & $\begin{array}{l}0.982 * * * \\
(0.155)\end{array}$ & $\begin{array}{l}0.0986 * * * \\
(0.008)\end{array}$ & $\begin{array}{l}-0.229 * * \\
(0.099)\end{array}$ & $\begin{array}{l}0.208 * * * \\
(0.042)\end{array}$ & $\begin{array}{l}-0.034 \\
(0.050)\end{array}$ \\
\hline $\begin{array}{l}\text { Household } \\
\text { size }\end{array}$ & $\begin{array}{l}1.002 * * * \\
(0.087)\end{array}$ & $\begin{array}{l}-0.0605 * \\
(0.034)\end{array}$ & $\begin{array}{l}-0.027 \\
(0.035)\end{array}$ & $\begin{array}{l}-0.861 * * * \\
(0.120)\end{array}$ & $\begin{array}{l}-0.022 * * * \\
(0.006)\end{array}$ & $\begin{array}{l}-0.22 * * * \\
(0.073)\end{array}$ & $\begin{array}{l}0.327 * * * \\
(0.029)\end{array}$ & $\begin{array}{l}-0.14 * * * \\
(0.047)\end{array}$ \\
\hline $\begin{array}{l}\text { Dependency } \\
\text { ratio }\end{array}$ & $\begin{array}{l}-3.171 * * * \\
(0.938)\end{array}$ & $\begin{array}{l}0.508 \\
(0.402)\end{array}$ & $\begin{array}{l}2.603 * * * \\
(0.385)\end{array}$ & $\begin{array}{l}2.617 * * \\
(1.119)\end{array}$ & $\begin{array}{l}-0.013 \\
(0.071)\end{array}$ & $\begin{array}{l}-0.882 \\
(0.719)\end{array}$ & $\begin{array}{l}0.118 \\
(0.300)\end{array}$ & $\begin{array}{l}-1.78 * * * \\
(0.518)\end{array}$ \\
\hline $\begin{array}{l}\text { Number of } \\
\text { schooling } 18\end{array}$ & $\begin{array}{l}-0.551 * * * \\
(0.154)\end{array}$ & $\begin{array}{l}0.087 \\
(0.058)\end{array}$ & $\begin{array}{l}0.141 * * \\
(0.067)\end{array}$ & $\begin{array}{l}0.443 * * * \\
(0.152)\end{array}$ & $\begin{array}{l}0.0187 * \\
(0.010)\end{array}$ & $\begin{array}{l}-0.194 * \\
(0.115)\end{array}$ & $\begin{array}{l}0.198 * * * \\
(0.052)\end{array}$ & $\begin{array}{l}-0.142 * \\
(0.083)\end{array}$ \\
\hline Sex of head & $\begin{array}{l}1.202 \\
(0.745)\end{array}$ & $\begin{array}{l}-0.498 \\
(0.371)\end{array}$ & $\begin{array}{l}1.720^{* * *} \\
(0.533)\end{array}$ & $\begin{array}{l}-0.582 \\
(0.729)\end{array}$ & $\begin{array}{l}0.030 \\
(0.051)\end{array}$ & $\begin{array}{l}-2.67 * * * \\
(0.665)\end{array}$ & $\begin{array}{l}0.641^{* *} \\
(0.254)\end{array}$ & $\begin{array}{l}0.154 \\
(0.519)\end{array}$ \\
\hline Age of head & $\begin{array}{l}-0.220 * * * \\
(0.069)\end{array}$ & $\begin{array}{l}-0.115^{* *} \\
(0.050)\end{array}$ & $\begin{array}{l}0.299 * * * \\
(0.037)\end{array}$ & $\begin{array}{l}-0.017 \\
(0.059)\end{array}$ & $\begin{array}{l}0.004 \\
(0.004)\end{array}$ & $\begin{array}{r}0.0947^{*} \\
(0.050)\end{array}$ & $\begin{array}{l}0.030 \\
(0.021)\end{array}$ & $\begin{array}{l}-0.074 * * \\
(0.034)\end{array}$ \\
\hline $\begin{array}{l}\text { Age of head } \\
\text { square }\end{array}$ & $\begin{array}{l}0.0027 * * * \\
(0.001)\end{array}$ & $\begin{array}{l}0.0011^{* * *} \\
(0.000)\end{array}$ & $\begin{array}{l}-0.0032^{* * * *} \\
(0.000)\end{array}$ & $\begin{array}{l}0.000 \\
(0.001)\end{array}$ & $\begin{array}{l}0.000 \\
(0.000)\end{array}$ & $\begin{array}{l}-0.0009 * \\
(0.001)\end{array}$ & $\begin{array}{l}-0.00037 * \\
(0.000)\end{array}$ & $\begin{array}{l}0.00058^{*} \\
(0.000)\end{array}$ \\
\hline Married head & $\begin{array}{l}-0.159 \\
(0.562)\end{array}$ & $\begin{array}{l}-0.519 \\
(0.433)\end{array}$ & $\begin{array}{l}0.333 \\
(0.264)\end{array}$ & $\begin{array}{l}-1.789 * * * \\
(0.622)\end{array}$ & $\begin{array}{l}-0.004 \\
(0.035)\end{array}$ & $\begin{array}{l}0.935^{* *} \\
(0.422)\end{array}$ & $\begin{array}{l}0.575 * * * \\
(0.168)\end{array}$ & $\begin{array}{l}0.628 * * \\
(0.254)\end{array}$ \\
\hline $\begin{array}{l}\text { Education } \\
\text { head }\end{array}$ & $\begin{array}{l}-0.074 \\
(0.141)\end{array}$ & $\begin{array}{l}-0.129 * \\
(0.070)\end{array}$ & $\begin{array}{l}0.211 * * * \\
(0.058)\end{array}$ & $\begin{array}{l}0.072 \\
(0.138)\end{array}$ & $\begin{array}{l}0.0278 * * * \\
(0.008)\end{array}$ & $\begin{array}{l}0.202 * * \\
(0.102)\end{array}$ & $\begin{array}{l}0.018 \\
(0.044)\end{array}$ & $\begin{array}{l}-0.33 * * * \\
(0.072)\end{array}$ \\
\hline Work head & $\begin{array}{l}2.752 * * * \\
(0.481)\end{array}$ & $\begin{array}{l}0.055 \\
(0.199)\end{array}$ & $\begin{array}{l}-0.195 \\
(0.334)\end{array}$ & $\begin{array}{l}-1.905^{* * * *} \\
(0.527)\end{array}$ & $\begin{array}{l}0.009 \\
(0.030)\end{array}$ & $\begin{array}{l}-0.652 \\
(0.468)\end{array}$ & $\begin{array}{l}-0.081 \\
(0.168)\end{array}$ & $\begin{array}{l}0.017 \\
(0.261)\end{array}$ \\
\hline $\begin{array}{l}\text { Local } \\
\text { Economic } \\
\text { condition }\end{array}$ & $\begin{array}{l}1.506 * * * \\
(0.244)\end{array}$ & $\begin{array}{l}-0.480 * * * \\
(0.112)\end{array}$ & $\begin{array}{l}-0.280 * * \\
(0.113)\end{array}$ & $\begin{array}{l}-1.669 * * * \\
(0.301)\end{array}$ & $\begin{array}{l}0.023 \\
(0.019)\end{array}$ & $\begin{array}{l}0.522 * * * \\
(0.189)\end{array}$ & $\begin{array}{l}0.135 \\
(0.088)\end{array}$ & $\begin{array}{l}0.242 * \\
(0.141)\end{array}$ \\
\hline $\begin{array}{l}\text { HH economic } \\
\text { condition }\end{array}$ & $\begin{array}{l}-0.429 \\
(0.310)\end{array}$ & $\begin{array}{l}-0.056 \\
(0.134)\end{array}$ & $\begin{array}{l}0.134 \\
(0.136)\end{array}$ & $\begin{array}{l}-0.371 \\
(0.296)\end{array}$ & $\begin{array}{l}-0.015 \\
(0.021)\end{array}$ & $\begin{array}{l}0.177 \\
(0.196)\end{array}$ & $\begin{array}{l}0.482 * * * \\
(0.105)\end{array}$ & $\begin{array}{l}0.079 \\
(0.151)\end{array}$ \\
\hline Region & $\begin{array}{l}-5.043 * * * \\
(0.493)\end{array}$ & $\begin{array}{l}-0.548^{* * *} \\
(0.165)\end{array}$ & $\begin{array}{l}0.706 * * * \\
(0.203)\end{array}$ & $\begin{array}{l}7.317 * * * \\
(0.531)\end{array}$ & $\begin{array}{l}0.431 * * * \\
(0.035)\end{array}$ & $\begin{array}{l}-1.51 * * * \\
(0.346)\end{array}$ & $\begin{array}{l}-0.488 * * * \\
(0.186)\end{array}$ & $\begin{array}{l}-0.87 * * * \\
(0.231)\end{array}$ \\
\hline Province & $\begin{array}{l}-0.570 \\
(0.425)\end{array}$ & $\begin{array}{l}0.097 \\
(0.136)\end{array}$ & $\begin{array}{l}-0.669 * * * \\
(0.166)\end{array}$ & $\begin{array}{l}1.538 * * * \\
(0.499)\end{array}$ & $\begin{array}{l}0.285 * * * \\
(0.031)\end{array}$ & $\begin{array}{l}1.341 * * * \\
(0.304)\end{array}$ & $\begin{array}{l}-0.889 * * * \\
(0.170)\end{array}$ & $\begin{array}{l}-1.13 * * * \\
(0.149)\end{array}$ \\
\hline Constant & $\begin{array}{l}88.33 * * * \\
(7.222)\end{array}$ & $\begin{array}{l}4.787 * * \\
(2.007)\end{array}$ & $\begin{array}{l}-27.13 * * * \\
(3.233)\end{array}$ & $\begin{array}{l}47.81 * * * \\
(11.610)\end{array}$ & $\begin{array}{l}2.074 * * * \\
(0.348)\end{array}$ & $\begin{array}{l}-36.8 * * * \\
(5.49)\end{array}$ & $\begin{array}{l}48.58 * * * \\
(1.887)\end{array}$ & $\begin{array}{l}-27.7 * * * \\
(4.244)\end{array}$ \\
\hline $\begin{array}{l}\text { Observations } \\
\text { R-squared }\end{array}$ & $\begin{array}{l}8671 \\
0.295\end{array}$ & $\begin{array}{l}8671 \\
0.042\end{array}$ & 8671 & $\begin{array}{l}8671 \\
0.284\end{array}$ & 8671 & $\begin{array}{l}8671 \\
0.097\end{array}$ & $\begin{array}{l}8671 \\
0.221\end{array}$ & 8671 \\
\hline Sigma & & & $\begin{array}{l}4.923 * * * \\
-0.192\end{array}$ & & $\begin{array}{l}0.680 * * * \\
-0.033\end{array}$ & & & $\begin{array}{l}5.225 * * * \\
-0.254\end{array}$ \\
\hline
\end{tabular}

Note: Standard errors in parentheses. Significance level: $* * * \mathrm{p}<0.01, * * \mathrm{p}<0.05, * \mathrm{p}<0.1$

Households' residence in rural or urban area or a particular province of also appears to substantially modify the consumption patterns. Urban households' spend proportionally more on 
education and housing, while those living in smaller provinces spend less on education and durable assets than households living in Punjab.

Table 4.6. Marginal Budget Shares by Access to remittances

\begin{tabular}{lllllll}
\hline \hline Consumption indicators & $\begin{array}{l}\text { HH with no } \\
\text { Foreign } \\
\text { Remittances }\end{array}$ & $\begin{array}{l}\text { HH with } \\
\text { Foreign } \\
\text { Remittances }\end{array}$ & z -stat & $\begin{array}{l}\text { HH with no } \\
\text { Domestic } \\
\text { Remittances }\end{array}$ & $\begin{array}{l}\text { HH with } \\
\text { Domestic } \\
\text { Remittances }\end{array}$ & z -stat \\
\hline \hline Food & 38.87 & 39.10 & 0.36 & 39.00 & 37.67 & -2.20 \\
Education & 3.43 & 4.23 & 1.90 & 3.43 & 3.92 & 1.60 \\
Health & 3.21 & 3.42 & 0.81 & 3.12 & 4.25 & 3.61 \\
Housing and Utilities & 27.20 & 26.05 & -1.82 & 27.17 & 26.76 & -0.80 \\
Recreation & 0.53 & 0.38 & -3.91 & 0.53 & 0.42 & -3.59 \\
Consumer non-durables & 10.72 & 10.92 & 0.87 & 10.71 & 10.92 & 1.12 \\
Miscellaneous & 14.08 & 13.65 & -0.70 & 14.08 & 13.78 & -0.70 \\
Durables & 1.97 & 2.26 & 0.68 & 1.96 & 2.28 & 1.08 \\
\hline \hline
\end{tabular}

The receipt of domestic remittances is significantly associated with three expenditure categories, two of which are statistically significant at the $1 \%$ level (Table 4.5). Recipient households have lower food and recreation budget shares and higher health spending. This reflects domestic remittance receiving households lower average income (average annual income being Rs. 172,900 as compared to Rs. 223,309 for non-recipient households' ). The share of health spending among recipients of domestic transfers is $36 \%$ higher (4.25\% vs $3.12 \%)$ than nonrecipient households (Table 4.6). Shares of food and recreation spending show less substantial difference, the two being lower by $3.4 \%$ and $21 \%$ respectively.

The consumption patterns of households living below the poverty line appear to be significantly different than those of their non-recipient counterparts (Table 4.7). Poor foreign remittance receiving households spend proportionally more on food and less on education, housing and recreation compared with non-recipient poor households'. Food spending is $11.1 \%$ higher, while that on education and housing is $42.6 \%$ and $18.5 \%$ lower respectively. In contrast, non-poor recipient households appear to diverge little from their non-recipient counterparts in their consumption patterns (Table 4.8). Unlike poor recipients, non-poor recipients seem to allocate a higher budget share to education. The behavior of poor recipients of foreign remittances differs remarkably from that of poor recipients of domestic transfers whose education and housing spending is significantly different than that of their non receiving counterparts. The expenditure 
patterns of non-poor households receiving transfers from within the country mostly resemble those of an average receiving household.

Table 4.7. Marginal Budget Shares - Poor households

\begin{tabular}{lllllll}
\hline \hline Consumption indicators & $\begin{array}{l}\text { HH with no } \\
\text { Foreign } \\
\text { Remittances }\end{array}$ & $\begin{array}{l}\text { HH with } \\
\text { Foreign } \\
\text { Remittances }\end{array}$ & z -stat & $\begin{array}{l}\text { HH with no } \\
\text { Domestic } \\
\text { Remittances }\end{array}$ & $\begin{array}{l}\text { HH with } \\
\text { Domestic } \\
\text { Remittances }\end{array}$ & z -stat \\
\hline \hline Food & 42.01 & 46.69 & 1.82 & 42.14 & 41.20 & -0.77 \\
Education & 1.97 & 1.13 & -1.97 & 1.92 & 2.49 & 1.60 \\
Health & 3.68 & 3.98 & 0.56 & 3.68 & 3.64 & -0.12 \\
Housing and Utilities & 26.41 & 21.53 & -3.58 & 26.24 & 27.69 & 1.42 \\
Recreation & 0.26 & 0.03 & -2.08 & 0.27 & 0.07 & -4.17 \\
Consumer non-durables & 12.92 & 12.49 & -0.55 & 12.89 & 13.13 & 0.46 \\
Miscellaneous & 12.05 & 12.08 & 0.02 & 12.14 & 11.09 & -1.70 \\
Durables & 0.69 & 2.06 & 1.04 & 0.71 & 0.67 & -0.15 \\
\hline \hline
\end{tabular}

Table 4.8. Marginal Budget Shares - Non-poor households

\begin{tabular}{lllllll}
\hline \hline Consumption indicators & $\begin{array}{l}\text { HH with no } \\
\text { Foreign } \\
\text { Remittances }\end{array}$ & $\begin{array}{l}\text { HH with } \\
\text { Foreign } \\
\text { Remittances }\end{array}$ & z -stat & $\begin{array}{l}\text { HH with no } \\
\text { Domestic } \\
\text { Remittances }\end{array}$ & $\begin{array}{l}\text { HH with } \\
\text { Domestic } \\
\text { Remittances }\end{array}$ & z -stat \\
\hline \hline Food & 38.24 & 38.20 & -0.07 & 38.38 & 36.79 & -2.36 \\
Education & 3.73 & 4.60 & 1.99 & 3.74 & 4.23 & 1.40 \\
Health & 3.11 & 3.32 & 0.74 & 3.01 & 4.36 & 3.83 \\
Housing and Utilities & 27.34 & 26.53 & -1.25 & 27.35 & 26.68 & -1.19 \\
Recreation & 0.58 & 0.45 & -3.29 & 0.58 & 0.49 & -2.64 \\
Consumer non-durables & 10.27 & 10.51 & 0.98 & 10.27 & 10.51 & 1.24 \\
Miscellaneous & 14.49 & 13.97 & -0.80 & 14.46 & 14.38 & -0.17 \\
Durables & 2.23 & 2.43 & 0.46 & 2.21 & 2.56 & 1.00 \\
\hline \hline
\end{tabular}

\subsubsection{PSM estimations}

Table 4.9 gives the results of the Propensity Score Matching estimations for foreign and domestic remittances. Results of Kernel matching, Radius matching and Nearest Neighbour matching are quite similar. Both foreign and domestic remittance receiving households appear to be significantly different from their non-recipient counterparts in four out of eight categories. Foreign remittance receiving households spend proportionally more on education, consumer goods, recreation and durables. However, the differences are robust only in the case of education spending. The share of education spending among recipients is substantially higher than their 
comparable non-recipient counterparts. This finding is similar to the one found using the Working Leser model.

Table 4.9. Remittances and household budget shares (Propensity Score Matching)

\begin{tabular}{lllll}
\hline Consumption indicators & NN & Kernel & Kernel (b.w 0.01) & Radius \\
\hline \multirow{2}{*}{ Foreign remittances } & & & & \\
& & & & \\
\hline Food & -0.094 & -0.567 & -0.336 & -0.391 \\
& $(0.848)$ & $(0.670)$ & $(0.699)$ & $(0.681)$ \\
\hline Health & 0.029 & -0.027 & -0.046 & -0.041 \\
& $(0.273)$ & $(0.206)$ & $(0.217)$ & $(0.210$ \\
\hline Education & $1.002^{* *}$ & $1.583^{* * *}$ & $1.462^{* * *}$ & $1.490^{* * *}$ \\
& $(0.505)$ & $(0.423)$ & $(0.430)$ & $(0.426)$ \\
\hline Housing and Utilities & -0.514 & -0.762 & -0.563 & -0.585 \\
& $(0.754)$ & $(0.608)$ & $(0.635)$ & $(0.618)$ \\
\hline Consumer non-durables & $-0.484^{*}$ & $-0.391^{*}$ & -0.346 & -0.324 \\
& $(0.264)$ & $(0.211)$ & $(0.221)$ & $(0.215)$ \\
\hline Recreation & -0.032 & $-0.082^{*}$ & $-0.085^{*}$ & $-0.086^{*}$ \\
& $(0.053)$ & $(0.048)$ & $(0.050)$ & $(0.049)$ \\
\hline Others & -0.462 & -0.370 & -0.55 & -0.606 \\
& $(0.640)$ & $(0.531)$ & $(0.551)$ & $(0.538)$ \\
\hline Durables & 0.556 & $0.616^{*}$ & 0.468 & $0.543^{*}$ \\
& $(0.421)$ & $(0.327)$ & $(0.336)$ & $(0.331)$ \\
\hline \hline
\end{tabular}

Domestic Remittances

\begin{tabular}{lllll}
\hline Food & -0.948 & -0.490 & -0.639 & -0.620 \\
& $(0.692)$ & $(0.526)$ & $(0.537)$ & $(0.532)$ \\
\hline Health & $1.148^{* * *}$ & $1.060^{* * *}$ & $0.993^{* * *}$ & $1.014^{* * *}$ \\
& $(0.244)$ & $(0.218)$ & $(0.221)$ & $(0.219)$ \\
\hline Education & $0.657^{*}$ & $0.547^{*}$ & $0.503^{*}$ & $0.552^{*}$ \\
& $(0.348)$ & $(0.287)$ & $(0.291)$ & $(0.289)$ \\
\hline Housing and Utilities & -0.885 & $-0.964^{* *}$ & $-0.832^{*}$ & $-0.849^{*}$ \\
& $(0.616)$ & $(0.472)$ & $(0.483)$ & $(0.477)$ \\
\hline Consumer non-durables & 0.093 & 0.210 & 0.183 & 0.173 \\
& $(0.220)$ & $(0.175)$ & $(0.178)$ & $(0.177)$ \\
\hline Recreation & $-0.106^{* * *}$ & $-0.128^{* * *}$ & $-0.093^{* * *}$ & $-0.102^{* * *}$ \\
& $(0.038)$ & $(0.030)$ & $(0.031)$ & $(0.031)$ \\
\hline Others & -0.358 & -0.550 & -0.480 & -0.511 \\
& $(0.490)$ & $(0.383)$ & $(0.390)$ & $(0.386)$ \\
\hline Durables & 0.399 & 0.316 & 0.365 & 0.342 \\
& $(0.314)$ & $(0.251)$ & $(0.255)$ & $(0.253)$ \\
\hline
\end{tabular}

Note: Observations lying the common support zone are discarded. Standard errors in parentheses. Significance level: *** $\mathrm{p}<0.01$, ** $\mathrm{p}<0.05, * \mathrm{p}<0.1$

The difference in Average Treatment Effect in Treatment (ATT) between treated and control group is substantially smaller than the unmatched difference. For the aforementioned four 
categories, the corresponding unmatched and ATT differences are 2.76 and 1.58 for education, 0.53 and 0.39 for consumer non-durables, 0.07 and 0.08 for recreation, and 1.4 and 0.62 for durable goods respectively ${ }^{25}$. This suggests that OLS systematically over-estimates the effect of remittances on consumption.

Unlike households that receive international transfers, recipients of domestic transfers seem to allocate a significantly high budget share to healthcare. Recipient households' share of healthcare spending is 30-36\% higher than their non-recipient counterparts. This is in line with the results of the Working Leser model. In addition to health, budget shares of recreation, education and housing and utilities also significantly differ, with recipient households spending proportionally more on education and less on the other two categories.

As before, poor recipient households allocate their budgets substantially differently compared with the non-recipient households (Table A4.13 and A4.14). Those receiving international transfers allocate a higher share of annual expenditure to food and a lower share to housing and utilities. Likewise, the budget shares of education and housing of domestic transfers receiving households are significantly higher than those of non-recipient households. These PSM results relating to households living below the poverty line need to be interpreted with caution, as they are based on a small number of matches.

\subsection{Discussion}

Our findings indicate that both foreign and domestic remittance receiving households have a greater proclivity for human capital accumulation. Recipients of foreign remittances spend proportionally more on education compared with the non-recipient households. This supports the view that migration from a developing to a developed country or from villages to urban centers brings greater realization of high returns to human capital among migrants and their households back home. Similarly, households receiving domestic transfers allocate a substantially greater share of the household budget to healthcare expenditures. This increase in health spending among the recipient households is probably meant for out of pocket health expenditures. In developing countries like Pakistan, public health care services are generally inadequate and

\footnotetext{
${ }^{25}$ The comparison are based on Gaussian Kernel estimation.
} 
consequently, well-to-do households often resort to private service providers for healthcare provision.

The difference between consumption patterns of households receiving international and domestic remittances may lie in the economic situation of those households. The amount of international remittances, especially sent by migrants settled in North America or Europe or the workers that have resided for a long time in the Gulf states, are usually higher and often go to more prosperous households. Better financial wherewithal of these households implies that basic necessities are already satisfied and additional income source in the form of receipts from abroad could be allocated to education. Domestic remittance receiving households, on the other hand, are on average poorer, and might not be in a position to allocate sufficient funds to healthcare prior to receiving money from the migrant. This also corroborates the argument of Clément (2011) in the context of Tajikistan that improving health outcomes is a short-term priority that comes before more long-term investments such as education or agriculture.

The finding that spending patterns of poor recipient households differ from the rest of the population also supports the argument that differences in consumption preferences among remittance receiving and non-receiving households arise partly due to differences in the economic conditions of the two groups of households. A greater share of the household budget allocated to food among low income households as opposed to the spending among the non-poor which is similar across the recipient and non-recipient households supports Engel's law. This finding is also reported in studies on other developing countries, such as Adams and Cuecuecha (2010b), Castaldo and Reilly (2007) and Tabuga (2007).

The varying consumption patterns of recipient and non-recipient households indicate that the fungibility of migrant remittances depends on the resources available to the receiving households, and the propensity to spend on different consumption items resulting from migrant remittances corresponds to the household's level of human development.

The fact that the consumption patterns of remittance receiving and non-receiving households differ substantially and that shares of education and healthcare spending are higher among recipient households suggests that the recipients perceive remittances as a temporary source of income which needs to be spent differently than the households' permanent income sources. This 
finding can be understood in light of the fact that much of the international migration from Pakistan is to the oil-rich states of the Persian Gulf which do not allow a permanent migration of the international labour force. Given the temporary nature of Pakistani overseas workers, a greater portion of the money remitted is used to improve the receiving households' health and education endowment. Remittances from domestic migrants are likewise perceived as temporary even though internal migration in Pakistan is often of a permanent nature. Internal migrants, while initially maintaining kinship ties with their home towns or villages, gradually settle down in the new environment. The process of remittance decay therefore sets in.

\subsection{Robustness and sensitivity checks}

An over all good balancing does not always imply joint balancing of all the covariates which can lead to less bias reduction. This problem can be tackled by integrating covariate balance into the weight function employed to adjust the control units (Hainmueller, 2012). This method of 'Entropy balancing' can significantly improve the quality of covariate balance and allows better use of information present in the data. The method preprocesses data by adjusting weights to include the selected covariates on the known moments of the covariate distribution, thereby obtaining exact covariate balance. Table 4.10 gives the results of Entropy balancing for the two types of remittances.

Table 4.10. Remittances and household consumption (Entropy balancing)

\begin{tabular}{lllllllll}
\hline & Food & Health & Education & $\begin{array}{l}\text { Housing } \\
\text { and } \\
\text { Utilities }\end{array}$ & $\begin{array}{l}\text { Consumer } \\
\text { non-durables }\end{array}$ & Recreation & Others & Durables \\
\hline $\begin{array}{l}\text { Foreign } \\
\text { Remittances }\end{array}$ & $\begin{array}{l}-0.145 \\
(0.587)\end{array}$ & $\begin{array}{l}0.059 \\
(0.206)\end{array}$ & $\begin{array}{l}1.125^{* *} \\
(0.451)\end{array}$ & $\begin{array}{l}-1.024^{*} \\
(0.533)\end{array}$ & $\begin{array}{l}-0.298 \\
(0.204)\end{array}$ & $\begin{array}{l}-0.087^{* *} \\
(0.042)\end{array}$ & $\begin{array}{l}-0.318 \\
(0.523)\end{array}$ & $\begin{array}{l}0.687^{*} \\
(0.387)\end{array}$ \\
\hline $\begin{array}{l}\text { Number of } \\
\text { households }\end{array}$ & 8671 & 8671 & 8671 & 8671 & 8671 & 8671 & 8671 & 8671 \\
\hline $\begin{array}{l}\text { Domestic } \\
\text { Remittances }\end{array}$ & $-0.768^{*}$ & $1.010^{* * *}$ & $0.560^{*}$ & $-0.779^{*}$ & 0.151 & $-0.097^{* * *}$ & -0.398 & 0.320 \\
\hline $\begin{array}{l}\text { Number of } \\
\text { households }\end{array}$ & 8671 & $(0.210)$ & $(0.289)$ & $(0.433)$ & $(0.171)$ & $(0.027)$ & $(0.380)$ & $(0.255)$ \\
\hline
\end{tabular}

Note: For entropy balancing, households without remittances are reweighted such that the means, variances and skewness of the control variables resemble those of households with remittances. Standard errors are given in parentheses. Significance level: $* * * \mathrm{p}<0.01, * * \mathrm{p}<0.05, * \mathrm{p}<0.1$

The estimations are carried out using Stata's ebalance package (Hainmueller and Xu, 2013). The results obtained are similar to the results from other matching methods. Foreign remittances still affect four out of eight household expenditure categories, and impact on the share of education 
spending remains the strongest. The significance of results for domestic remittances improves and the impact on the budget share of food also turns significant. Other categories retain their signs and significance.

\subsection{Concluding remarks}

This study examined consumption patterns of Pakistani households in the context of international and domestic remittances by using the representative 2010-2011 Pakistan Social and Living Standards Measurement survey. A number of conclusions can be drawn from the study:

First, although budget shares for several expenditure categories are similar across remittance receiving and non-receiving households, those for three rubrics are substantially different. Remittances, therefore, cannot be deemed as entirely fungible. Secondly, recipient households perceive remittances as a mainly temporary source of income and spend them on the household members' education and healthcare. The share of education and healthcare spending is significantly higher among recipient households. This positive impact of remittances on the household resources dedicated to human capital is in line with the findings of previous studies on developing countries such as Acosta et al. (2007), Adams and Cuecuecha (2010b), and highlights the beneficial effects of remittances. Third, findings do not support the assertion that remittances are spent on frivolous consumption, as there is no evidence in favour of remittances raising the share of the so-called 'unproductive expenditures' such as conspicuous spending on social ceremonies and status-oriented consumer products. There is even some weak evidence suggesting a higher share of spending on durable items (usually deemed more productive) among foreign remittance receiving households. Finally, the differences in consumption patterns owing to foreign and internal remittances may partly be due to varying income levels of the two sets of households. International remittance receiving households in Pakistan are on average more prosperous than domestic remittance recipients, and probably enjoy a different level of consumption satisfaction. In the same vein, differences in consumption patterns are also clearly visible among poor and non-poor recipients. This suggests that for poor households, remittances are part of the strategy to improve access to nutrition, whereas for the more well-to-do households, remittances are a means to accumulate human and physical capital. 


\section{References}

Acosta, P., Fajnzylber, P., \& Lopez, J. H. (2007). The impact of remittances on poverty and human capital: evidence from Latin American household surveys, (Vol. 4247), World Bank.

Adams, Richard H. Jr. (1998). Remittances, Investment and Rural Asset Accumulation in Pakistan.Economic Development and Cultural Change 47, 155-73.

Adams , R. H., \& Cuecuecha, A. (2010a). The economic impact of international remittances on poverty and household consumption and investment in Indonesia, (Vol.5433), World Bank.

Adams, Richard H. Jr. \& Cuecuecha, A. (2010b). Remittances, household expenditure and investment in Guatemala. World Development, 38(11), 1626-1641.

Adams, Richard H. Jr. (1991). The economic uses and impacts of international remittances in rural Egypt, Economic Development and Cultural Change , University of Chicago Press, 39(4), 695-722

Ahmed, V., Sugiyarto, G., \& Jha, S. (2010). Remittances and household Welfare: A case study of Pakistan, 194. Asian Development Bank.

Alderman, H. (1996). Saving and economic shocks in rural Pakistan. Journal of Development Economics 51, 343-365.

Amuedo-Dorantes, C., \& Pozo, S. (2011). New evidence on the role of remittances on healthcare expenditures by Mexican households'. Review of Economics of the Household, 9(1), 6998.

Athukorala, P. (1990). International contract migration and the reintegration of return migrants: The experience of Sri Lanka. International Migration Review, 323-346.

Arif, G. M. (2009). Economic and social impacts of remittances on households' : The case of Pakistani migrants working in Saudi Arabia. Pakistan Institute of Development Economics.

Arif, G. M. (2005). Internal migration and household well-being: Myth or reality. Internal Labour Migration in Pakistan. Institute of Developing Economies, Japan External Trade Organisation, Chiba, Japan.

Becker, S. O., \& Ichino, A. (2002). Estimation of average treatment effects based on propensity scores. The stata journal, 2(4), 358-377.

Bryson, A., Dorsett, R., \& Purdon, S. (2002). The use of propensity score matching in the evaluation of active labour market policies. 
Caliendo, M., \& Kopeinig, S. (2008). Some practical guidance for the implementation of propensity score matching. Journal of economic surveys, 22(1), 31-72.

Chami, R., Jahjah, S., \& Fullenkamp, C. (2003). Are immigrant remittance flows a source of capital for development. International Monetary Fund.

Clément, M. (2011). Remittances and household expenditure patterns in Tajikistan: A propensity score matching analysis. Asian Development Review, 28(2).

Chandavarkar, A. G. (1980). Use of migrants remittances in labor-exporting countries. Finance \& development, 17(2), 36.

Cardona Sosa, L., \& Medina, C. (2006). Migration as a safety net and effects of remittances on household consumption: The case of Colombia (No. 414). Banco de la Republica de Colombia.

Castaldo, A., \& Reilly, B. (2007). Do migrant remittances affect the consumption patterns of Albanian households' . South-Eastern Europe Journal of Economics, 1(1), 25-54.

Cuong, N. V. (2009). Impacts of international and internal remittances on household welfare: Evidence from Viet Nam. Asia-Pacific Development Journal, 16(1), 59-92.

Deaton A., Muellbauer J. (1999). Economics and consumer behavior. Cambridge University Press, Cambridge.

Dehejia, R. H., \& Wahba, S. (2002). Propensity score-matching methods for non-experimental causal studies. The Review of Economics and Statistics, 84(1), 151-161.

Diamond, A., \& Sekhon, J. S. (2013). Genetic matching for estimating causal effects: A general multivariate matching method for achieving balance in observational studies. Review of Economics and Statistics, 95(3), 932-945.

DiPrete, T. A., \& Gangl, M. (2004). Assessing bias in the estimation of causal effects: Rosenbaum bounds on matching estimators and instrumental variables estimation with imperfect instruments. Sociological methodology, 34(1), 271-310.

Durand, J., \& Massey, D. S. (1992). Mexican migration to the United States: a critical review. Latin American Research Review, 27(2), 3-42.

Durand, J., W. Kandel, E.A. Parrado and D.S. Massey. (1996). International migration and development in Mexican communities. Demography, 33(2): 249-264.

Duvendack, M., \& Palmer-Jones, R. (2012). High noon for microfinance impact evaluations: reinvestigating the evidence from Bangladesh. The Journal of Development Studies, 48(12), 1864-1880. 
Gangl, M. (2004). RBOUNDS: Stata module to perform Rosenbaum sensitivity analysis for average treatment effects on the treated. Statistical Software Components.

Hainmueller, J. (2012). Entropy balancing for causal effects: A multivariate reweighting method to produce balanced samples in observational studies., Political Analysis , 20 (1): 25-46.

Hainmueller, J., \& Xu, Y. (2013). Ebalance: A Stata package for entropy balancing. Journal of Statistical Software, 54(7).

Heckman, J., Ichimura, H., \& Todd, P. (1997). Matching as an econometric evaluation estimator. Review of Economic Studies, 65(2), 261-294.

Heckman, J.J., Lalonde, R.J. and J.A. Smith (1999). The economics and econometrics of active labour programs. In: O. Ashen felter \& D. Card (Eds.), Handbook of labor economics 1865-2097.

Holland, P. (1986). Statistics and causal inference. Journal of the American Statistical Association 81(396), 945-960.

Jimenez, M.A.C. (2009). Household development in Tlapanana: A comparative study between households' receiving remittances and households' not receiving remittances. Journal of Poverty, 13(3), 331-349.

Kifle, T. (2007). Do remittances encourage investment in education? Evidence from Eritrea. GEFAME Journal of African Studies, 4(1).

Lee, W. S. (2013). Propensity score matching and variations on the balancing test. Empirical economics, 44(1), 47-80.

Leser, C. E. V. (1963). Forms of Engel functions. Econometrica: Journal of the Econometric Society, 694-703.

Lechner, M. (1999). The effects of enterprise-related training in East Germany on individual employment and earnings. Annales d'Economie et de Statistique, 97-128.

Lechner, M. (2002). Program heterogeneity and propensity score matching: An application to the evaluation of active labor market policies. Review of Economics and Statistics, 84(2), 205-220.

Leuven, E., \& Sianesi, B. (2012). PSMATCH2: Stata module to perform full Mahalanobis and propensity score matching, common support graphing, and covariate imbalance testing. Statistical Software Components.

Massey, D. S. et al., (1987). Return to Aztlan: The social process of international migration from Western Mexico, Berkeley,University of California Press. 
McKenzie, D. J., \& Sasin, M. J. (2007). Migration, remittances, poverty, and human capital: conceptual and empirical challenges (Vol. 4272). World Bank Publications.

Osili, U. O. (2004). Migrants and housing investments: Theory and evidence from Nigeria*. Economic Development and Cultural Change, 52(4), 821-849.

Rosenbaum, P.R. (2002) Observational Studies. 2nd edition. New York: Springer.

Rosenbaum, P. R., \& Rubin, D. B. (1985). Constructing a control group using multivariate matched sampling methods that incorporate the propensity score. The American Statistician, 39(1), 33-38.

Rosenbaum, P. R., \& Rubin, D. B. (1983). The central role of the propensity score in observational studies for causal effects. Biometrika, 70(1), 41-55.

Russell, S. S., Jacobsen, K., \& Stanley, W. D. (1990). International migration and development in Sub-Saharan Africa (Vol. 2, No. 102).

Sianesi, B. (2004). An evaluation of the Swedish system of active labor market programs in the 1990s. Review of Economics and Statistics, 86(1), 133-155.

Tabuga, A. D. (2007). International remittances and household expenditures: The Philippine Case (No. DP 2007-18). Philippine Institute for Development Studies.

Taylor, J. E., \& Mora, J. (2006). Does migration reshape expenditures in rural households' ?: evidence from Mexico (Vol. 3842). World Bank Publications.

Working, H. (1943). Statistical laws of family expenditure, Journal of the American Statistical Association, 38(221), 43-56.

Yang, D. (2005). International migration, human capital, and entrepreneurship: evidence from Philippine migrants exchange rate shocks (Vol. 3578). World Bank Publications.

Woodruff, Christopher, and Rene M. Zenteno (2007). Migration networks and microenterprises in Mexico, Journal of Development Economics 82(2) ,509-528 


\section{Appendix}

Table A4.11. Items included in the asset index.

\begin{tabular}{llll}
\hline Assets & Comp1 & Assets & Comp1 \\
\hline Eigenvectors & \multicolumn{3}{l}{ Eigenvectors } \\
\hline Electricity Iron & 0.2607 & Tractor & 0.0363 \\
\hline Electric Fan & 0.1887 & Mobile & 0.2137 \\
\hline Sewing Machine & 0.1958 & Cooking range & 0.1166 \\
\hline Radio & 0.0574 & Burner & 0.2380 \\
\hline Chair & 0.2334 & Washing machine & 0.2708 \\
\hline Watch & 0.1971 & Phone & 0.2112 \\
\hline Television & 0.2507 & Electricity & 0.1597 \\
\hline VCP & 0.1203 & Cooking_fuel & 0.2401 \\
\hline Refrigerator & 0.2694 & Toilet & 0.1754 \\
\hline Air Cooler & 0.1361 & Number of rooms & 0.1658 \\
\hline Air Conditioner & 0.1598 & House_ownership & -0.0303 \\
\hline Computer & 0.1743 & Roof & 0.2236 \\
\hline Bicycle & 0.0095 & Walls & 0.2204 \\
\hline Motorcycle & 0.1451 & Piped_water & 0.1409 \\
\hline Car & 0.1415 & & $\mathbf{7 . 3 8 3 2}$ \\
\hline Eigen values & & & $\mathbf{0 . 2 5 4 6}$ \\
\hline Explained Proportion of variance & & $\mathbf{0 . 2 5 4 6}$ \\
\hline Explained cumulative proportion of & & & \\
\hline variance & & & \\
\hline
\end{tabular}

Figure A4.1. Density distributions for the estimated propensity scores for foreign remittance receiving and non-receiving households'

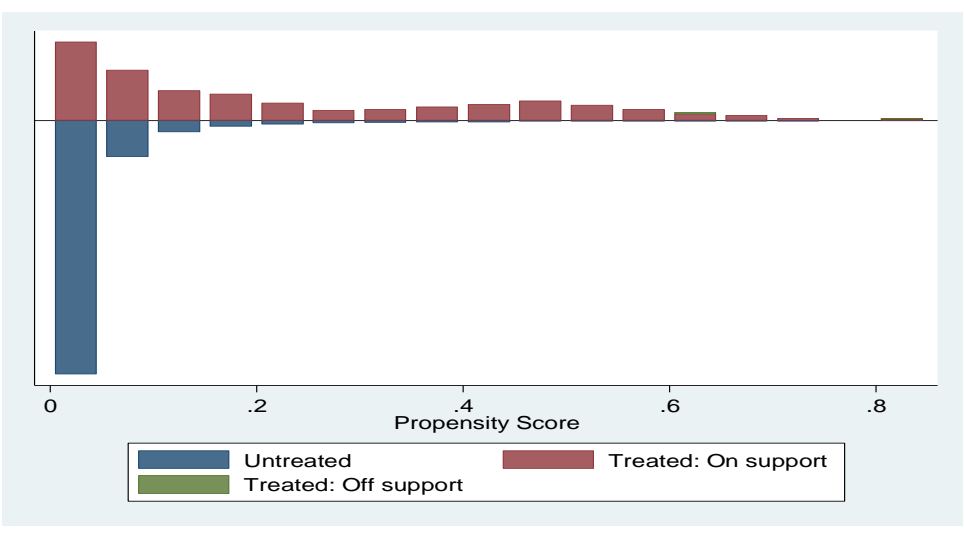


Figure A4.2. Density distributions for the estimated propensity scores for domestic remittance receiving and non-receiving households'

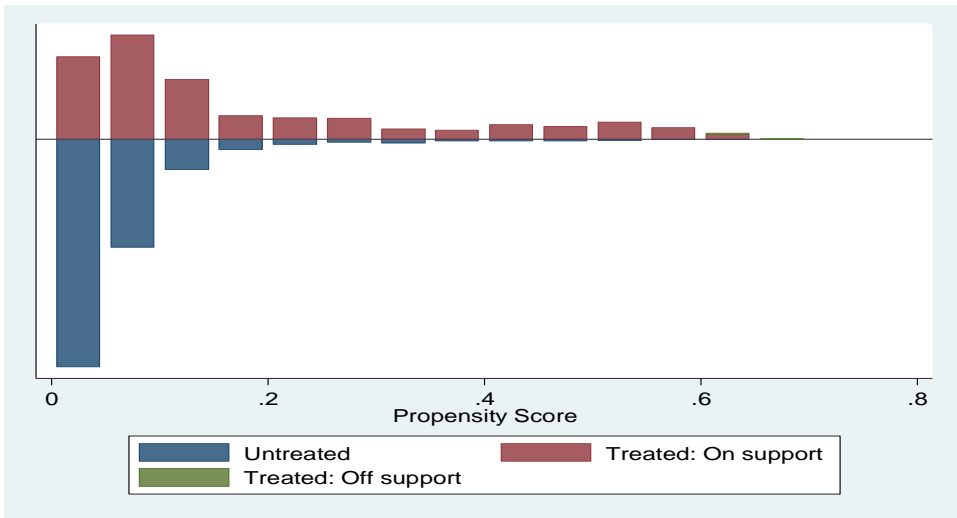

Figure A4.3 Pre- and post-matching bias reduction for different Matching estimations (Foreign Remittances).

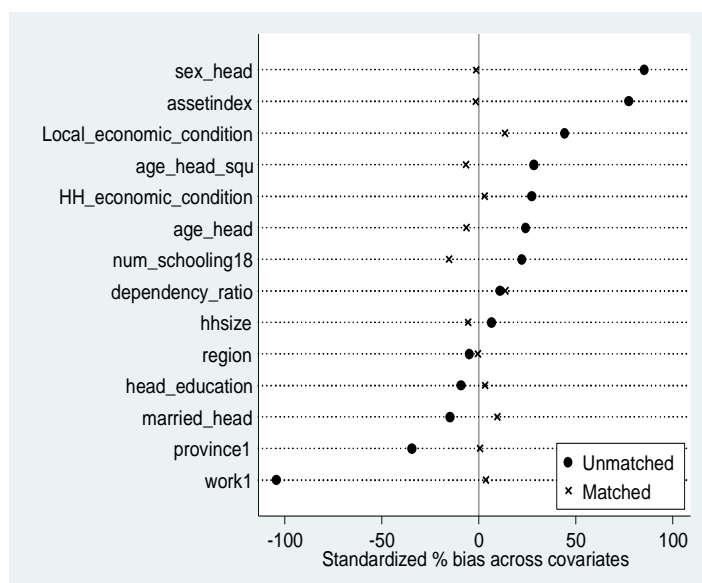

(a) Nearest Neighbor

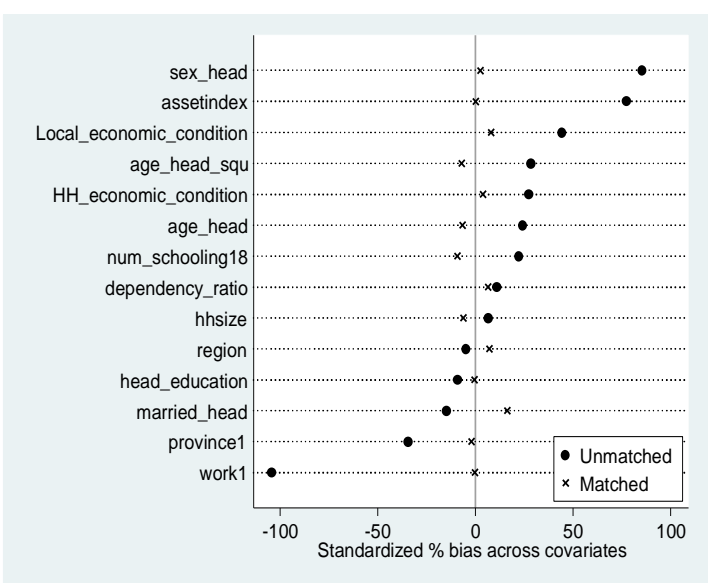

(c) Gaussian Kernel Bandwidth 0.01

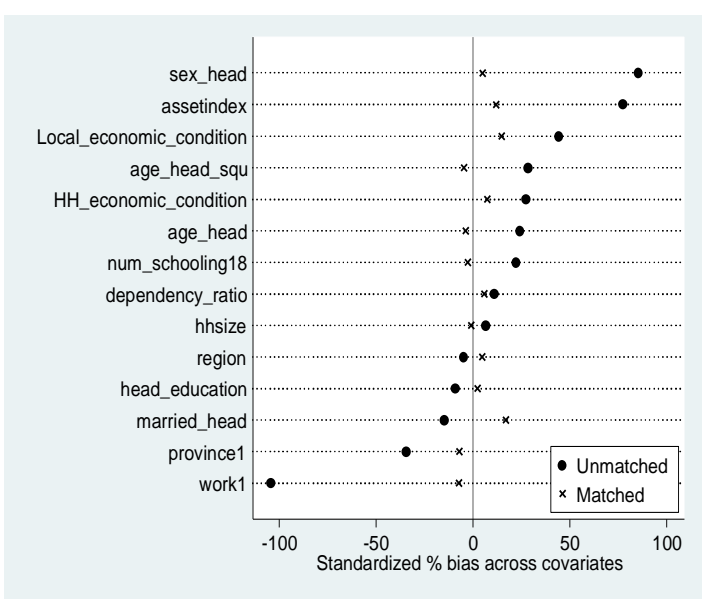

(b) Gaussian Kernel

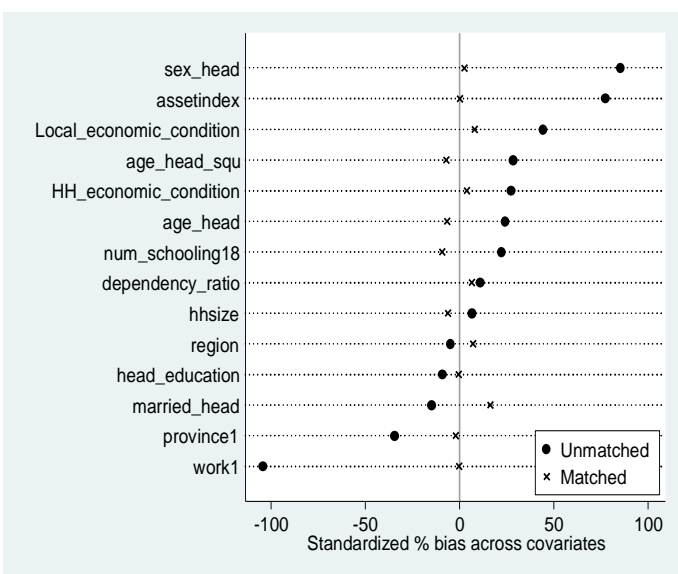

(d) Radius 
Figure A4.4. Pre- and post-matching bias reduction for different Matching estimations (Domestic Remittances).

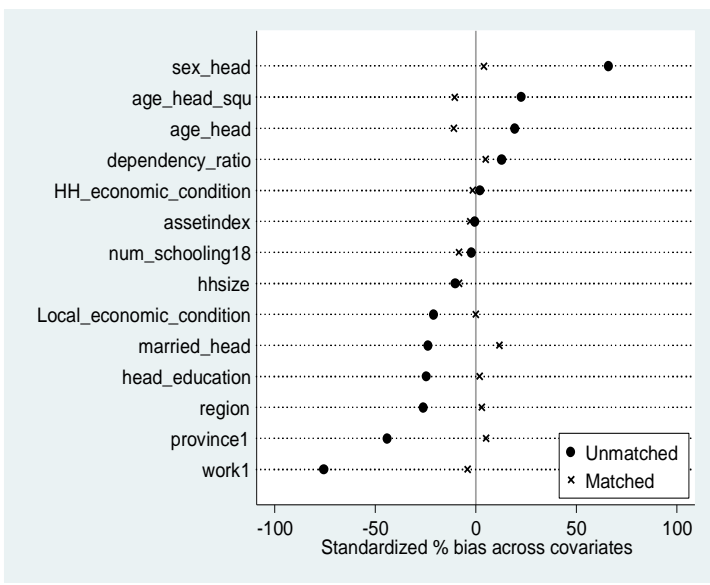

(a) Nearest Neighbor

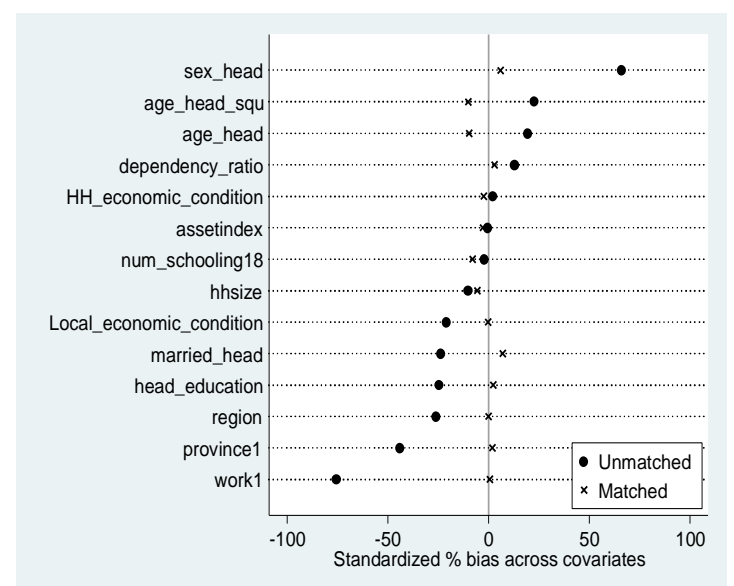

(c) Gaussian Kernel Bandwidth 0.01

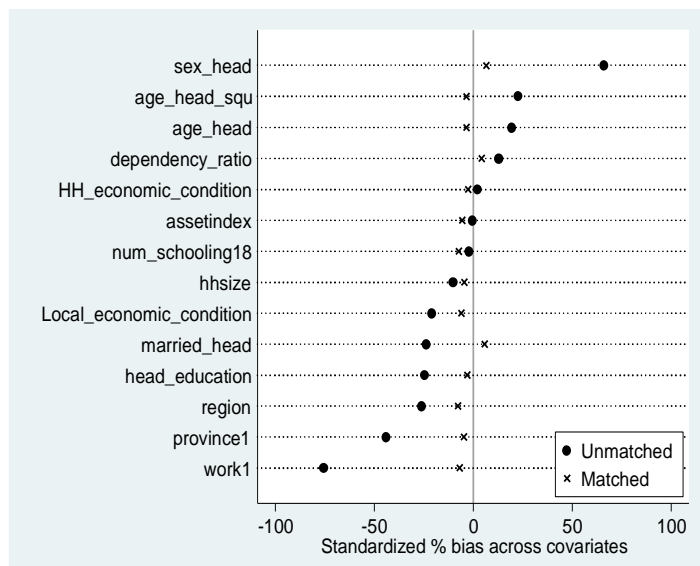

(b) Gaussian Kernel

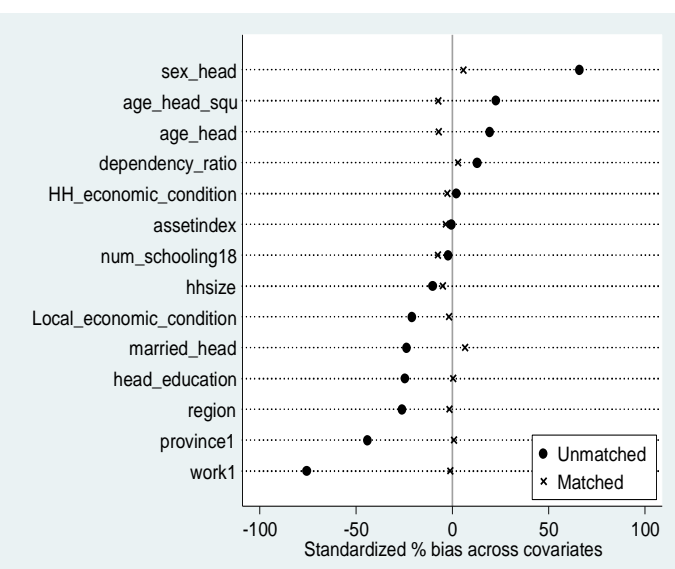

(d) Radius 
Table A4.12. Quality of Matching Indicators

\begin{tabular}{l|l|l}
\hline Test indicator & $\begin{array}{l}\text { Foreign } \\
\text { Remittances }\end{array}$ & $\begin{array}{l}\text { Domestic } \\
\text { Remittances }\end{array}$ \\
\hline Before Matching & & \\
\hline Mean absolute bias & 35.31223 & 25.02 \\
\hline Pseudo $R^{2}$ & 0.258 & 0.146 \\
\hline LR $\chi^{2}(P$-value $)$ & 887.61 & 666.08 \\
& $(0.000)$ & $(0.000)$ \\
\hline After matching & & \\
\hline Nearest neighbor matching & 6.10 & 5.48 \\
\hline Mean absolute bias & 0.007 & 0.007 \\
\hline Pseudo $R^{2}$ & 8.95 & 12.79 \\
\hline LR $\chi^{2}(P$-value $)$ & $(0.834)$ & $(0.543)$ \\
\hline Kernel based matching & & \\
\hline Mean absolute bias & 6.79 & 5.16 \\
\hline Pseudo $R^{2}$ & 0.012 & 0.004 \\
\hline LR $\chi^{2}(P$-value $)$ & 14.77 & 7.44 \\
& $(0.394)$ & $(0.917)$ \\
\hline Kernel based matching $(\mathbf{b . w} \mathbf{0 . 0 1})$ & & \\
\hline Mean absolute bias & 5.46 & 4.24 \\
\hline Pseudo $R^{2}$ & 0.008 & 0.003 \\
\hline LR $\chi^{2}(P$-value $)$ & 9.17 & 5.56 \\
& $(0.820)$ & $(0.976)$ \\
\hline Radius matching & & \\
\hline Mean absolute bias & 6.24 & 3.88 \\
\hline Pseudo $R^{2}$ & 0.009 & 0.002 \\
\hline LR $\chi^{2}(P$-value $)$ & 10.45 & $(0.995)$ \\
\hline & $(0.728)$ & \\
\hline & & \\
\hline
\end{tabular}


Table A4.13. Remittances and Budget Shares - Non-poor households (Propensity Score Matching)

\begin{tabular}{lllll}
\hline Consumption indicators & NN & Kernel & Kernel (b.w 0.01) & Radius \\
\hline \multirow{2}{*}{ Foreign remittances } & & & & \\
& & & & \\
\hline Food & $-1.734^{* *}$ & -0.904 & -0.562 & -0.836 \\
& $(0.840)$ & $(0.682)$ & $(0.721)$ & $(0.705)$ \\
\hline Health & 0.173 & -0.051 & -0.131 & -0.788 \\
& $(0.240)$ & $(0.215)$ & $(0.223)$ & $(0.224)$ \\
\hline Education & $1.562^{* * *}$ & $1.667^{* * *}$ & $1.802^{* * *}$ & $1.741^{* * *}$ \\
& $(0.509)$ & $(0.443)$ & $(0.457)$ & $(0.451)$ \\
\hline Housing and Utilities & -0.266 & -0.378 & -0.513 & -0.395 \\
& $(0.763)$ & $(0.632)$ & $(0.669)$ & $(0.653)$ \\
\hline Consumer non-durables & -0.280 & -0.277 & -0.174 & -0.268 \\
& $(0.264)$ & $(0.215)$ & $(0.221)$ & $(0.222)$ \\
\hline Recreation & -0.012 & -0.081 & $-0.088^{*}$ & $-0.084 *$ \\
& $(0.056)$ & $(0.050)$ & $(0.023)$ & $(0.051)$ \\
\hline Others & -0.614 & -0.501 & -0.787 & -0.562 \\
& $(0.661)$ & $(0.555)$ & $(0.577)$ & $(0.568)$ \\
\hline Durables & $1.190^{*}$ & 0.525 & 0.454 & 0.482 \\
& $(0.385)$ & $(0.345)$ & $(0.360)$ & $(0.353)$ \\
\hline \hline
\end{tabular}

\section{Domestic Remittances}

\begin{tabular}{lllll}
\hline Food & -0.422 & -0.689 & -0.850 & -0.830 \\
& $(0.757)$ & $(0.587)$ & $(0.607)$ & $(0.595)$ \\
\hline Health & $0.932^{* * *}$ & $1.257^{* * *}$ & $0.208^{* * *}$ & $1.210^{* * *}$ \\
& $(0.324)$ & $(0.252)$ & $(0.257)$ & $(0.254)$ \\
\hline Education & 0.413 & 0.484 & 0.543 & 0.527 \\
& $(0.413)$ & $(0.329)$ & $(0.337)$ & $(0.332)$ \\
\hline Housing and Utilities & $-1.309^{*}$ & $-1.279^{* *}$ & $-1.264^{* *}$ & $-0.121^{* *}$ \\
& $(0.712)$ & $(0.531)$ & $(0.550)$ & $(0.538)$ \\
\hline Consumer non-durables & 0.316 & 0.242 & 0.289 & 0.212 \\
& $(0.234)$ & $(0.186)$ & $(0.192)$ & $(0.188)$ \\
\hline Recreation & $-0.073^{*}$ & $-0.116^{* * *}$ & $-0.089^{* *}$ & $-0.087^{* *}$ \\
& $(0.043)$ & $(0.034)$ & $(0.035)$ & $(0.034)$ \\
\hline Others & -0.157 & -0.317 & -0.208 & -0.246 \\
& $(0.569)$ & $(0.439)$ & $(0.451)$ & $(0.443)$ \\
\hline Durables & 0.300 & 0.418 & 0.372 & 0.419 \\
& $(0.376)$ & $(0.296)$ & $(0.304)$ & $(0.299)$ \\
\hline
\end{tabular}

Note: Observations lying the common support zone are discarded. Standard errors in parentheses.

Significance level: $* * * \mathrm{p}<0.01, * * \mathrm{p}<0.05, * \mathrm{p}<0.1$ 
Table A4.14. Remittances and Budget Shares - Poor households (Propensity Score Matching)

\begin{tabular}{lllll}
\hline Consumption indicators & NN & Kernel & Kernel (b.w 0.01) & Radius \\
\hline \multirow{2}{*}{ Foreign remittances } & & & & \\
& & & & \\
\hline Food & $8.112^{* *}$ & $6.233^{* *}$ & $6.217^{* *}$ & $7.195^{* * *}$ \\
& $(3.264)$ & $(2.569)$ & $(2.840)$ & $(2.678)$ \\
\hline Health & -0.236 & -0.053 & 0.093 & -0.286 \\
& $(0.848)$ & $(0.528)$ & $(0.555)$ & $(0.527)$ \\
\hline Education & -0.643 & -0.092 & -0.192 & -0.287 \\
& $(0.960)$ & $(0.557)$ & $(0.613)$ & $(0.577)$ \\
\hline Housing and Utilities & $-6.458^{* * *}$ & $-7.296^{* * *}$ & $-6.268^{* * *}$ & $-6.667^{* * *}$ \\
& $(2.260)$ & $(1.597)$ & $(1.734)$ & $(1.649)$ \\
\hline Consumer non-durables & 0.199 & -0.576 & -0.481 & $-1.186^{* *}$ \\
& $(0.762)$ & $(0.634)$ & $(0.632)$ & $(0.601)$ \\
\hline Recreation & -0.248 & -0.126 & -0.175 & -0.137 \\
& $(0.276)$ & $(0.122)$ & $(0.134)$ & $(0.126)$ \\
\hline Others & 0.821 & 1.169 & 0.417 & 0.807 \\
& $(1.888)$ & $(1.507)$ & $(1.666)$ & $(1.579)$ \\
\hline Durables & -1.548 & 0.739 & 0.389 & 0.561 \\
& $(2.060)$ & $(0.779)$ & $(0.867)$ & $(0.820)$ \\
\hline \hline
\end{tabular}

\section{Domestic Remittances}

\begin{tabular}{lllll}
\hline Food & -0.666 & -1.377 & -0.496 & -1.398 \\
& $(1.287)$ & $(1.088)$ & $(1.094)$ & $(1.082)$ \\
\hline Health & 0.449 & 0.113 & -0.017 & 0.137 \\
& $(0.399)$ & $(0.351)$ & $(0.360)$ & $(0.354)$ \\
\hline Education & $0.764^{*}$ & $0.992^{*}$ & $0.745^{*}$ & $0.986^{* *}$ \\
& $(0.509)$ & $(0.488)$ & $(0.467)$ & $(0.497)$ \\
\hline Housing and Utilities & 1.566 & $1.851^{*}$ & 1.005 & $1.594^{*}$ \\
& $(1.390)$ & $(0.982)$ & $(1.006)$ & $(0.986)$ \\
\hline Consumer non-durables & 0.219 & 0.084 & -0.207 & -0.519 \\
& $(0.506)$ & $(0.449)$ & $(0.450)$ & $(0.435)$ \\
\hline Recreation & $-0.218^{* *}$ & $-0.194^{* *}$ & $-0.173^{* * *}$ & $-0.169^{* * *}$ \\
& $(0.086)$ & $(.0578)$ & $(.0567)$ & $(0.057)$ \\
\hline Others & $-1.770^{* *}$ & -1.342 & -0.897 & $-1.091^{*}$ \\
& $(0.751)$ & $(0.600)$ & $(0.606)$ & $(0.600)$ \\
\hline Durables & -0.345 & -0.127 & 0.040 & -0.007 \\
& $(0.407)$ & $(0.185)$ & $(0.191)$ & $(0.185)$ \\
\hline
\end{tabular}

Note: Observations lying the common support zone are discarded. Standard errors in parentheses.

Significance level: $* * * \mathrm{p}<0.01, * * \mathrm{p}<0.05, * \mathrm{p}<0.1$ 
Table A4.15. Rosenbaum bounds sensitivity analysis. Foreign remittances as treatment variable

\begin{tabular}{|c|c|c|c|c|c|c|c|}
\hline & \multirow[t]{2}{*}{$\Gamma$} & \multicolumn{2}{|c|}{$\begin{array}{l}\text { Wilcoxon's signed } \\
\text { rank test }\end{array}$} & \multicolumn{2}{|c|}{$\begin{array}{l}\text { Hodges-Lehmann } \\
\text { point estimates }\end{array}$} & \multicolumn{2}{|c|}{$\begin{array}{l}95 \% \text { confidence } \\
\text { Interval }\end{array}$} \\
\hline & & sig+ & sig- & t-hat+ & t-hat- & $\mathrm{CI}+$ & CI- \\
\hline \multirow[t]{3}{*}{ Education } & 1.00 & 0.015 & 0.015 & 0.710 & 0.710 & 0.070 & 1.366 \\
\hline & 1.05 & 0.041 & 0.005 & 0.570 & 0.843 & -0.064 & 1.519 \\
\hline & 1.10 & 0.090 & 0.001 & 0.446 & 0.990 & -0.197 & 1.660 \\
\hline \multirow[t]{2}{*}{ Recreation } & 1.00 & 0.044 & 0.044 & -0.043 & -0.043 & -0.126 & 0.000 \\
\hline & 1.05 & 0.017 & 0.100 & -0.064 & -0.030 & -0.143 & 0.017 \\
\hline \multirow[t]{2}{*}{$\begin{array}{l}\text { Consumer Non- } \\
\text { durable }\end{array}$} & 1.00 & 0.008 & 0.008 & -0.375 & -0.375 & -0.905 & 0.142 \\
\hline & 1.05 & 0.035 & 0.166 & -0.493 & -0.258 & -1.017 & 0.257 \\
\hline \multirow[t]{2}{*}{ Durable } & 1.00 & 0.058 & 0.058 & 0.158 & 0.158 & -0.038 & 0.388 \\
\hline & 1.05 & 0.124 & 0.023 & 0.115 & 0.201 & -0.084 & 0.441 \\
\hline
\end{tabular}

Table A4.16. Rosenbaum bounds sensitivity analysis. Domestic remittances as treatment variable

\begin{tabular}{|c|c|c|c|c|c|c|c|}
\hline & \multirow[t]{2}{*}{$\Gamma$} & \multicolumn{2}{|c|}{$\begin{array}{l}\text { Wilcoxon's signed } \\
\text { rank test }\end{array}$} & \multicolumn{2}{|c|}{$\begin{array}{l}\text { Hodges-Lehmann } \\
\text { point estimates }\end{array}$} & \multicolumn{2}{|c|}{$\begin{array}{l}\text { 95\% confidence } \\
\text { Interval }\end{array}$} \\
\hline & & sig+ & sig- & t-hat+ & t-hat- & $\mathrm{CI}+$ & CI- \\
\hline \multirow[t]{5}{*}{ Health } & 1.00 & 0.000 & 0.000 & 0.648 & 0.648 & 0.366 & 0.938 \\
\hline & 1.10 & 0.000 & 0.000 & 0.501 & 0.799 & 0.216 & 1.098 \\
\hline & 1.20 & 0.006 & 0.000 & 0.365 & 0.938 & 0.079 & 1.245 \\
\hline & 1.30 & 0.050 & 0.000 & 0.241 & 1.071 & -0.044 & 1.389 \\
\hline & 1.25 & 0.107 & 0.000 & 0.182 & 1.133 & -0.101 & 1.457 \\
\hline \multirow[t]{2}{*}{ Housing } & 1.00 & 0.075 & 0.075 & -0.855 & -0.855 & -2.039 & 0.310 \\
\hline & 1.05 & 0.025 & 0.181 & -1.172 & -0.534 & -2.353 & 0.616 \\
\hline \multirow[t]{2}{*}{ Education } & 1.00 & 0.024 & 0.024 & 0.420 & 0.420 & 0.000 & 0.863 \\
\hline & 1.05 & 0.073 & 0.006 & 0.301 & 0.537 & -0.088 & 0.983 \\
\hline \multirow[t]{3}{*}{ Recreation } & 1.00 & 0.000 & 0.000 & -0.033 & -0.033 & -0.096 & 0.000 \\
\hline & 1.10 & 0.000 & 0.010 & -0.062 & -0.003 & -0.123 & 0.000 \\
\hline & 1.20 & 0.000 & 0.081 & -0.096 & 0.000 & -0.160 & 0.000 \\
\hline
\end{tabular}

Note: * Gamma - log odds of differential assignment due to unobserved factors sig+ - upper bound significance level sig- - lower bound significance level t-hat+ - upper bound Hodges-Lehmann point estimate t-hat- - lower bound Hodges-Lehmann point estimate CI+ - upper bound confidence interval $(a=.95) \mathrm{CI}-\quad-$ lower bound confidence interval $(\mathrm{a}=.95)$ 


\title{
Chapter 5 :Great Expectation? Remittances and Asset Accumulation in Pakistan
}

Joint work with Mazhar Mughal ${ }^{\dagger}$

\begin{abstract}
This study examines asset accumulation patterns of the recipients of foreign and domestic remittances. Using the representative 2010-11 Pakistani households' survey and employing a number of matching routines, we analyse stocks of consumer, productive, housing and financial assets among migrants' stay-behind households. We find that asset accumulation among remittance-receiving households depends upon the nature and magnitude of remittances as well as the economic situation and geographical location of the recipient households. Foreign remittances lead to a substantial increase in household assets while no significant change results from domestic remittances. Households receiving foreign remittances hold a higher stock of assets for all categories of assets, even though the increase in productive assets is low. Moreover, rural and poor recipients of foreign remittances accumulate more assets than their non-recipient counterparts. Asset accumulation also increases with the amount of remittance received. Findings show that foreign remittances are considered as a mainly transitory income, and are used to generate precautionary savings in cash and kind.
\end{abstract}

Keywords: Foreign remittances; Domestic remittances; Asset accumulation; Pakistan

JEL Codes: F24; I2; O15; O53.

Acknowledgment

We would like to thank Prof. Stephan Klasen for his comments and suggestions, which helped us to considerably improve this study.

\footnotetext{
$\dagger$ Pau Business School, France.
} 


\subsection{Introduction}

Sending a member away from home is a substantial investment undertaken by the migrant household, whose ensuing monetary returns provide the household with an additional source of earnings. These migrant remittances diversify the household's income portfolio and improve its standard of living. Research on remittance flows to developing countries has revealed the uses of these transfers and their impact on household welfare. Remittances lead to significant changes in the household consumption patterns. In some cases, they lead to higher marginal shares of food and consumer goods (Adams and Cuecuecha, 2010a; Chami, Fullenkamp and Jahjah, 2005; Clément, 2011), while in others the remittances help the households improve their education and healthcare outcomes and provide capital for productive investments (Adams, 1998; Adams and Cuecuecha, 2010b; Ahmed and Mughal, 2014; Amuedo-Dorantes and Pozo, 2011; Taylor and Mora, 2006).

The latter finding suggests that remittances are mainly considered as a temporary source of income by the migrant households (Ahmed and Mughal, 2014). If this conclusion is valid, then this migrant households' consumption behaviour should also be reflected in their asset accumulation patterns ${ }^{26}$. Temporary or irregular income receipts are therefore more likely to be saved or invested, while permanent income is spent on regular, scheduled expenditures (Friedman, 1957; Ando and Modigliani, 1957). The resulting stock of assets and monetary savings should serve as a cushion against health risks, natural catastrophes, economic downturns and other exogenous shocks.

Extant literature lacks consensus on the use of remittances for asset accumulation by the migrant households Studies from Albania (Nicholson, 2001), Mexico (Chiodi et.al, 2012), Pakistan (Adams, 1998), Thailand (Garip, 2014) and the Philippines (Quisumbing and McNiven, 2010) find evidence of higher productive assets resulting from remittances. Osili (2004) finds that remittances to Nigeria lead to a substantial improvement in housing assets. On the other hand, evidence from Ethiopia (Andersson, 2014), Pakistan (Lefebvre, 1999) and Sri Lanka (Prabal and Ratha, 2012) favour the pessimistic assessment that remittances do not lead to the accumulation of productive assets.

\footnotetext{
${ }^{26}$ Household assets refer to the set of material belongings, financial resources and intangible assets including the households' accumulated human capital.
} 
These conflicting conclusions raise a number of questions:

Do such positive (negative) views hide a more nuanced image when assets are disaggregated into various subcategories (e.g. durable goods, housing, financial assets and productive assets)?

Does this remittance behaviour extend to both forms of remittances, i.e. foreign and domestic?

Do recipient households in the rural areas acquire assets in the same way as the urban households do?

Are asset accumulation patterns of households living below the poverty line similar to those of the non-poor households?

Does the amount of remittances influence asset holdings of the recipient households?

This study seeks answers to these questions by analyzing the 2010-2011 Pakistan Social and Living-standards Measurement (PSLM) survey. We find that the asset accumulation patterns do vary with respect to the type of remittance received, the kind of assets involved, the region of residence of the households, and the income level of the recipients. The welfare effects of remittances are therefore contingent upon the nature and magnitude of remittances as well as the economic situation and geographical location of the recipient households. The study differs from Adams (1998). The latter examines asset accumulation patterns among rural households in four district of Pakistan, while our representative dataset covers asset details for both the urban and the rural households in the country.

The remainder of the study is organized as follows: The next section provides a quick overview of related literature. Section 3 describes the socioeconomic profile of the migrant households and shows bivariate statistics on remittances and household assets. Empirical methodology is presented in Section 4 followed by the study's key findings in Section 5. The penultimate section gives the sensitivity and robustness checks undertaken. Conclusions follow.

\subsection{Remittances and asset accumulation - a brief literature overview}

Of late, researchers have increasingly focused on assets to understand household welfare and development outcomes in the developing countries. Assets are easier to measure and do not face recall and measurement issues that plague the other welfare indicators. They provide a useful tool to assess the stock of resources available to the household, thereby reflecting the household's long term welfare situation. The more assets people have, the less vulnerability and insecurity they experience in the face of risks, insecurity, and violence (Moser, 1998). Therefore, the migration process and the monetary and in-kind transfers that follow can be expected to raise 
the migrant household's asset stock. In the presence of imperfect capital markets and credit constraints, remittances serve as a means to accumulate productive assets, which in turn generate income and savings for the household (Chiodi et.al , 2012; Taylor, 1999).

For instance, remittances are reported to be used for purchasing machinery for small-scale family enterprises, livestock and agricultural equipment for farms, as well as land and commercial property for new businesses (Adams, 1991; Dustmann and Kirchkamp, 2002; Nicholson, 2001; Taylor, 1992; Woodruff and Zenteno, 2004). Along with agricultural and commercial land, housing and real estate are one of the migrant remittances' important uses (Findlay and Samha, 1986; Osili, 2004). Egyptian migrant households, for instance, use remittance money to replace their crowded and traditional mud-brick houses with modern red brick buildings (Adams, 1991). Houses constructed for self-consumption improve the household's living conditions, while land and property serve as a relatively secure avenue for investment accessible to households in countries with underdeveloped financial markets.

On the other hand, migration is an expensive joint-venture whose costs include foregone consumption and household labour. Migrant households can therefore also be expected to enjoy the fruits of this investment by purchasing more consumer items and labour-saving goods. This could explain the evidence for higher consumer asset accumulation coupled with no significant productive asset accumulation among migrant households (Adams and Cuecuecha, 2010a; Andersson, 2014).

The aforementioned conflicting evidence could be due, in part, to the kind of assets examined, the income level of the households, and the type of remittances. Prabal and Ratha (2012), for example, find that remittance income contributes to an increase in human capital accumulation among Sri Lankan children, even if there is no evidence that it leads to higher physical asset accumulation among the recipient households. Adams and Cuecuecha (2010a) report that households' receiving international remittances in Indonesia are poorer than other types of households', and thus tend to spend their remittances at the margin on consumption rather than investment goods.

In contrast, Garip (2013) shows that rich Thai households lose productive assets with migration, potentially due to the reduction in the labor force available to maintain local economic activities, while poor households gain productive assets. 
Adams (1998) finds that external remittances have a much more important influence than internal remittances do on the accumulation of physical assets in rural Pakistan. Being a recipient of foreign remittances is positively associated with ownership of irrigated and rain-fed land, whereas internal remittances do not have a positive and statistically significant impact on the accumulation of any rural assets. Adams explains this difference by the fact that agricultural land is highly valued in rural Pakistan and is therefore inaccessible to the recipients of lower average internal remittances compared with higher foreign remittances. However, investment on livestock or non-farm assets does not seem to increase with remittances, possibly due to lower returns to these assets. Lefebvre (1999) and Watkins (2003), in contrast, report no productive asset accumulation resulting from remittances, as most of it is spent to cover the recipient households' basic necessities.

\subsection{Data description}

This study is based on the 2010 - 2011 round of Pakistan Social and Living-Standards Measurement Survey (PSLM). The survey is carried out on a sample of 16,341 households' representative of the country's population at the national and urban/rural level. Villages are taken as primary sample units in rural areas while urban sampling is based on enumeration blocks. Households in each of the 1,180 sampled villages and enumeration blocks are considered secondary sampling units, and a sample of 16 and 12 households is respectively selected from each village and urban enumeration block for this purpose. The survey collects data on household income, consumption, wealth, social and demographic features, savings, and work of the households. Table 5.1 compares the profiles of foreign and domestic remittance recipient and non-recipient households. Recipient households show significant demographic, economic and spatial divergence from the non-receiving households. Households receiving foreign remittances are on average larger with a higher number of dependents. Their heads are older and somewhat less educated. $43 \%$ of recipient household heads are females compared with $7 \%$ of the nonrecipient households. This reflects the fact that international migration from Pakistan is overwhelmingly male, and as a result females (usually the migrant's wife) take up additional responsibilities. Only $43 \%$ of recipient household heads report working regularly as compared to $83 \%$ of the non-recipient heads. A proportionally higher number of recipient households is based in rural areas, while the provincial distribution is not significantly different. 
Table 5.1. Profiles of remittance recipient and non-recipients

\begin{tabular}{|c|c|c|c|c|c|c|}
\hline Variable & $\begin{array}{l}\text { HH with no } \\
\text { Foreign } \\
\text { Remittances } \\
\end{array}$ & $\begin{array}{l}\text { HH with } \\
\text { Foreign } \\
\text { Remittance }\end{array}$ & $\begin{array}{l}\text { Two } \\
\text { sample } \\
\text { t-test } \\
\end{array}$ & $\begin{array}{l}\text { HH with no } \\
\text { Domestic } \\
\text { Remittances } \\
\end{array}$ & $\begin{array}{l}\text { HH with } \\
\text { Domestic } \\
\text { Remittances } \\
\end{array}$ & $\begin{array}{l}\text { Two } \\
\text { sample } \\
\text { t-test } \\
\end{array}$ \\
\hline \multicolumn{7}{|l|}{ Demographic indicators } \\
\hline Age of head & 46.26 & 48.82 & 4.01 & 46.03 & 49.47 & 6.86 \\
\hline Household size & 6.36 & 6.82 & 2.82 & 6.45 & 5.80 & -6.04 \\
\hline Dependency ratio & 0.49 & 0.54 & 4.53 & 0.49 & 0.54 & 6.32 \\
\hline Education of head & 2.31 & 2.15 & -2.04 & 2.33 & 1.99 & 5.99 \\
\hline Sex of head & 0.07 & 0.43 & 16.11 & 0.06 & 0.40 & 20.27 \\
\hline Work status of head & 0.83 & 0.43 & -17.21 & 0.85 & 0.48 & -19.87 \\
\hline \multicolumn{7}{|l|}{ Economic indicators } \\
\hline $\begin{array}{l}\text { Total Income including } \\
\text { remittances }\end{array}$ & 188380.80 & 356659.70 & 4.21 & 199682.80 & 179065.10 & -3.35 \\
\hline $\begin{array}{l}\text { Income per capita including } \\
\text { remittances }\end{array}$ & 33107.56 & 62340.11 & 2.93 & 34814.17 & 33646.01 & -0.93 \\
\hline Local economic conditions & -0.34 & 0.07 & 10.63 & -0.31 & -0.36 & -1.97 \\
\hline $\begin{array}{l}\text { Households } \\
\text { economic condition } \\
\text { Location indicators }\end{array}$ & -0.22 & -0.05 & 5.90 & -0.21 & -0.22 & -0.47 \\
\hline Resides in Punjab & 0.41 & 0.37 & -1.47 & 0.43 & 0.25 & -8.66 \\
\hline Resides in urban areas & 0.35 & 0.25 & -3.86 & 0.36 & 0.19 & -10.80 \\
\hline
\end{tabular}

Source: Authors' calculations using PSLM (HIES) 2010-11

Recipient households earn almost twice as much as the non-recipient households, with the per capita income of Rs. 62 thousand compared with Rs. 33 thousand for non-recipients.

Recipients of international transfers also enjoy greater access to durable assets (Table 5.2). A substantially higher proportion of foreign remittance receiving households' possess home appliances such as television sets, refrigerators, washing machines, air conditioners and computers, as well as vehicles such as cars and motorbikes. An interesting exception are bicycles, whose ownership does not significantly vary with the incidence of remittance from abroad. Bicycles are considered a means of transport for the poor in the country, and its use therefore does not increase with income. A higher proportion of households with foreign remittances holds agricultural and non-agricultural land as well as commercial buildings, and possesses productive assets such as tractors and livestock. Likewise, these households' savings in cash and gold are substantially higher than those of the non-recipient households'. $91 \%$ of foreign remittance receiving households own a house compared with $85 \%$ of the non-recipients. The quality of housing of the recipient households is also superior, with more rooms, better quality roof and walls, and higher access to amenities like toilets, tap water, electricity, natural gas and telephones. On the other hand, households receiving domestic transfers report poor economic 
conditions with lower household income and asset holdings compared to the non-receiving households (Table 5.1).

Table 5.2. Household assets by access to remittances

\begin{tabular}{|c|c|c|c|c|c|c|}
\hline & $\begin{array}{l}\text { HH with no } \\
\text { Foreign } \\
\text { Remittances } \\
\end{array}$ & $\begin{array}{l}\text { HH with } \\
\text { Foreign } \\
\text { Remittances } \\
\end{array}$ & $\begin{array}{l}\text { Two } \\
\text { sample } \\
\text { t-test } \\
\end{array}$ & $\begin{array}{l}\text { HH with no } \\
\text { Domestic } \\
\text { Remittances } \\
\end{array}$ & $\begin{array}{l}\text { HH with } \\
\text { Domestic } \\
\text { Remittances } \\
\end{array}$ & $\begin{array}{l}\text { Two } \\
\text { sample t- } \\
\text { test } \\
\end{array}$ \\
\hline \multicolumn{7}{|l|}{ Durable assets } \\
\hline Iron & 0.72 & 0.94 & 14.84 & 0.72 & 0.79 & 4.37 \\
\hline Electric Fan & 0.89 & 0.95 & 4.88 & 0.89 & 0.92 & 1.68 \\
\hline Radio & 0.16 & 0.28 & 5.16 & 0.17 & 0.15 & -1.48 \\
\hline Chair & 0.63 & 0.93 & 22.98 & 0.64 & 0.73 & 5.54 \\
\hline Watch & 0.77 & 0.96 & 17.07 & 0.78 & 0.8 & 1.64 \\
\hline TV & 0.55 & 0.72 & 7.18 & 0.56 & 0.54 & -0.9 \\
\hline Air Conditioner & 0.05 & 0.1 & 4.22 & 0.05 & 0.03 & -4.48 \\
\hline VCP & 0.05 & 0.09 & 3.63 & 0.05 & 0.04 & -1.31 \\
\hline Refrigerator & 0.37 & 0.72 & 17.23 & 0.39 & 0.38 & -0.26 \\
\hline Air Cooler & 0.06 & 0.15 & 5.55 & 0.07 & 0.07 & 0.12 \\
\hline Computer & 0.07 & 0.16 & 5.82 & 0.07 & 0.07 & -1.07 \\
\hline Bicycle & 0.28 & 0.28 & -0.03 & 0.28 & 0.26 & -1.09 \\
\hline Motorbike & 0.24 & 0.27 & 1.51 & 0.25 & 0.17 & -6.27 \\
\hline Car & 0.04 & 0.07 & 2.85 & 0.04 & 0.02 & -4.01 \\
\hline Mobile phone & 0.77 & 0.92 & 12.04 & 0.78 & 0.76 & -1.84 \\
\hline Cooking Range & 0.02 & 0.06 & 2.91 & 0.03 & 0.02 & -1.4 \\
\hline Burner & 0.37 & 0.49 & 4 & 0.39 & 0.27 & -7.1 \\
\hline Washing Machine & 0.42 & 0.77 & 15.72 & 0.44 & 0.39 & -2.84 \\
\hline \multicolumn{7}{|l|}{ Housing Quality } \\
\hline Ownership & 0.85 & 0.91 & 4.81 & 0.85 & 0.9 & -4.13 \\
\hline Number of Rooms & 2.24 & 3.12 & 17.39 & 2.27 & 2.45 & 4.67 \\
\hline Roof Material & 2.27 & 2.83 & 8.23 & 2.32 & 2.13 & -4.16 \\
\hline Wall Material & 2.66 & 2.78 & 3.62 & 2.66 & 2.68 & 0.48 \\
\hline Drinking Source & 5.4 & 5.63 & 2.67 & 5.41 & 5.41 & -0.03 \\
\hline Toilet type & 3.7 & 4.49 & 8.79 & 3.75 & 3.69 & -0.85 \\
\hline Cooking fuel type & 2.96 & 3.11 & 2.64 & 2.99 & 2.78 & -5.52 \\
\hline Lighting Source & 2.88 & 2.95 & 3.96 & 2.88 & 2.93 & 3.01 \\
\hline Access to telephone & 1.83 & 2.08 & 11.61 & 1.85 & 1.83 & -1.02 \\
\hline $\begin{array}{l}\text { Water supply } \\
\text { Productive Assets }\end{array}$ & 1.95 & 1.98 & 4 & 1.95 & 1.95 & -0.41 \\
\hline Tractor & 0.02 & 0.04 & 1.5 & 0.03 & 0.01 & -3.08 \\
\hline $\begin{array}{l}\text { Commercial } \\
\text { Building }\end{array}$ & 0.05 & 0.05 & 0.61 & 0.05 & 0.03 & -2.32 \\
\hline $\begin{array}{l}\text { Non Agricultural } \\
\text { Land }\end{array}$ & 0.02 & 0.05 & 2.7 & 0.03 & 0.02 & -0.82 \\
\hline Agricultural Land & 0.26 & 0.38 & 5.11 & 0.25 & 0.33 & 3.72 \\
\hline Livestock & 0.28 & 0.35 & 2.54 & 0.28 & 0.31 & 1.22 \\
\hline $\begin{array}{l}\text { Number of adults } \\
\text { with schooling }\end{array}$ & 1.84 & 2.25 & 5.1 & 1.89 & 1.62 & -4.86 \\
\hline $\begin{array}{l}\text { Average years of } \\
\text { education } \\
\text { Financial Assets }\end{array}$ & 6.13 & 6.49 & 2.71 & 6.17 & 5.96 & -1.61 \\
\hline Gold & 109903.3 & 195487.4 & 4.96 & 116782.1 & 115771.2 & -0.12 \\
\hline Cash Savings & 167914 & 399196.8 & 1.34 & 202020.1 & 140485.5 & -1.75 \\
\hline
\end{tabular}

Source: Authors' calculations using PSLM (HIES) 2010-11 
Similar to the foreign remittance recipients, domestic remittance recipient households are mostly rural with high dependency ratios. However, these households are on average smaller than nonreceiving households and are located in the Punjab province to a greater degree compared with the rest of the country. The demographic and education profile of their heads is similar to that of foreign remittance receiving households.

The asset endowment of households receiving domestic transfers is mostly comparable to that of the non-recipients, even though non-recipients possess more of certain types of electronic equipment such as air conditioners, washing machines and television sets (Table 5.2). An exception is sewing machines which are more frequently found among recipient households. Sewing machines are productive tools that allow women from low-income households a source of earning while working from home. Ownership of transport vehicles such as bicycles, cars and motorbikes is more common among non-recipient households. The amount of cash savings is similarly low among domestic remittance receiving households. There is little difference in the ownership patterns of non-agricultural land and commercial property, whereas more recipient households hold agricultural land and livestock. In the same vein, even though more domestic remittance recipients possess their own home compared with the non-recipients (90\% as against $85 \%$ ) and enjoy more space at home (2.45 rooms compared with 2.3 available to the nonrecipients), the quality of housing (e.g. roof and wall material, type of toilet, source of drinking water) and facilities available at home (e.g. electricity, water supply and telephone) are similar regardless of the access to domestic remittances.

\subsection{Methodology}

\subsubsection{Model and variable selection}

We examine the relationship between remittances and household assets controlling for various economic, social, demographic and locational factors. A total of 38 tangible and intangible individual and household assets are considered. In order to fully gauge the extent of asset holdings of the household, both lumpy (e.g. houses, commercial property, cars) and non-lumpy (e.g. electric fans, watches, radio) type of assets are included. Qualitative asset indicators take values in ascending order of the asset quality. For instance, the indicator for toilet availability assigns the highest value to flush toilets connected to sewerage system with flush toilets 
connected to tanks or open drain, dry raised or pit latrine and no toilet respectively taking lower values.

The assets are aggregated into a unidimensional index by employing the Polychoric Principal Component Analysis. This technique proposed by Kolenikov and Angeles (2004, 2009) uses Polychoric correlation rather than Pearson correlation, and is considered better suited to deal with a mixture of continuous, binary and ordinal data compared to Principal Component Analysis. The first component thereby obtained explains 37 percent of the information common to the constituent variables. A higher value of the index indicates that the household holds more and better quality assets. For example, a household obtaining a high index value is likely to possess a bricked house with adequate sanitary environment, electricity, natural gas for cooking, piped drinking water and hold more physical assets, human capital and financial resources. The composite index is created using Stata's polychoric user routine. For ease of interpretation, the asset index is standardized to take a mean value of zero and a standard deviation of one.

In addition to the aggregate index, assets are combined into four different groups: consumer, productive, housing and financial. Definitions of the four categories are shown in Table 5.3. Consumer assets include electronic home appliances and transport vehicles, productive assets consist of household's land and commercial holdings as well as livestock and agricultural equipment, while housing assets comprise indicators of home ownership, housing quality and household amenities. Barring agricultural land, tractor and livestock, all assets can be available to both the rural as well as urban households; therefore the same index is employed for both groups of households. The household's human capital endowment is counted as a productive asset. The number of adults having received some schooling and the household's average education levels proxy for the stock of human capital the household possesses. The financial assets category is composed of the logged sum of the amount of household savings in cash and gold. Other monetary indicators such as borrowings and repaid loans contain few observations and are therefore not included in the index. The list of variables included in each asset category along with their PCA Eigen values are given in Table A5.11. The consumer durables index is generated using PCA as the indicators for all the constituent assets are binary. 
Table 5.4 gives bivariate relationship between aggregate and category-wise asset indices on the one hand and the two types of remittances on the other. Households receiving foreign remittances seem to possess more assets whereas the domestic remittance receiving households appear to have lower and often insignificantly different asset portfolio compared with their nonrecipient counterparts.

Table 5.3. Description of expenditure categories

\begin{tabular}{|c|c|}
\hline Asset category & Description \\
\hline Housing Quality & $\begin{array}{l}\text { Ownership, no. of rooms, roof material (RCC/RBC, steel/cement sheets, } \\
\text { wood/bamboo, other), wall material (burnt bricks/blocks, mud bricks/blocks, } \\
\text { other), source of drinking water (pipe, motor pump, hand pump, well } \\
\text { (open/closed), outdoor tap, river/stream, other), type of toilet (flush } \\
\text { connected to sewerage, flush connected to tank, dry raised latrine, pit latrine, } \\
\text { other, no toilet), cooking fuel (natural gas, wood, dung cake, other), lighting } \\
\text { source(electricity, kerosene oil/diesel/petrol, other), type of telephone } \\
\text { (landline and mobile mobile, none,), distance from water supply (near: } 0-14 \\
\text { minutes far: } 15-60 \text { minutes,) }\end{array}$ \\
\hline Consumer Durables & $\begin{array}{l}\text { iron, electric fan, sewing machine, radio, chair, watch, TV, VCP, refrigerator, } \\
\text { air cooler, air conditioner, computer, bicycle, motorbike, car, mobile phone, } \\
\text { cooking range, burner, washing machine }\end{array}$ \\
\hline Productive Assets & $\begin{array}{l}\text { tractor, commercial building, non-agricultural land, agricultural land, } \\
\text { livestock, number of adults with some schooling, average years of education }\end{array}$ \\
\hline Financial Assets & Cash savings, amount of gold/jewelry \\
\hline
\end{tabular}

Table 5.4. Remittances and household assets: Bivariate statistics

\begin{tabular}{lllll}
\hline Asset indicators & $\begin{array}{l}\text { Households with no } \\
\text { Remittances }\end{array}$ & $\begin{array}{l}\text { Households with } \\
\text { Remittances }\end{array}$ & Difference & $\begin{array}{l}\text { Two sample } \\
\text { t-test }\end{array}$ \\
\hline Foreign Remittances & & & & \\
Total assets & 5.31 & 6.12 & 0.81 & 7.43 \\
Housing quality & 4.48 & 5.15 & 0.67 & 10.53 \\
Consumer durables & 3.95 & 5.57 & 1.62 & 16.42 \\
Productive assets & 0.80 & 1.00 & 0.20 & 4.83 \\
Financial assets (millions of Rs.) & 0.14 & 0.33 & 0.18 & 2.58 \\
Domestic Remittances & & & & -1.91 \\
Total assets & 5.39 & 5.22 & -0.17 & -2.32 \\
Housing Quality & 4.53 & 4.41 & -0.08 & -1.07 \\
Consumer durables & 4.05 & 3.97 & 0.07 & 1.54 \\
Productive assets & 0.81 & 1.21 & -0.01 & -1.07 \\
Financial assets (millions of Rs.) & 0.16 & 0.14 & & \\
\hline
\end{tabular}

Source: Authors' calculations using PSLM (HIES) 2010-11

Remittances are primarily taken as a binary variable to indicate whether or not the household received transfers from within or outside the country during the preceding year. Independent variables that control for the remittance - asset holding relationship include economic factors such as the household's per capita annual income (excluding the amount of remittances received), number of working adults at home, the employment status of the household head, and 
two indicators of the household's subjective evaluation of the local and household economic situations compared with those prevailing in the previous year.

Demographic factors include household characteristics such as the household size and the share of dependents in the household, as well as individual features such as age, sex and marital status of the household head. Moreover, region and province of residence control for the household's geographical location. The region variable takes rural areas as the baseline given that majority of the country's population lives in villages. The province variable takes Punjab as the baseline and compares it with the other three provinces taken together. Punjab is the most populous province accounting for $56 \%$ of the country's population.

The subsequent baseline model can be given as:

$$
A_{i j}=\beta_{i}+\gamma_{i}\left(\log Y_{j}\right)+\delta_{i} R_{j}+\sum_{j} \mu_{i j} Z_{j}+\varepsilon_{i j}
$$

Where $A_{i j}$ is the dependent variable which alternately takes the standardized index value for total assets and the four asset categories. It represents assets categories $i$ for households $j . R_{j}$ indicates whether or not the household receives foreign or domestic remittances, $Z_{j}$ represents the set of household characteristics that can affect assets behaviour and $\varepsilon_{i j}$ is the error term. Definitions and means of selected explanatory variables are given in Table A5.12 in the appendix. The resulting useable sample contains 5107 observations.

The aforementioned model is also employed to estimate the effect of the amount of remittances received. The dummy variables for the amount of the two types of remittances are constructed by taking the median values of Rs. 170,000 (foreign remittance) and Rs. 60,600 (domestic remittance) as the cut-off point. In addition to the baseline model, estimations are separately carried out to compare poor and non-poor households as well as rural and urban households. A household earning less than $\$ 1.25$ a day in annualized adult equivalent terms is taken as poor. Adult equivalence is based on the modified OECD equivalence scale with household head, other adults and minors respectively assigned weights of $1,0.5$ and $0.3^{27}$. The calculated poverty line

\footnotetext{
${ }^{27}$ An alternative weightage of 1, 0.8 and 0.5 is also employed. Results are available upon request
} 
is based on a 2010-2011 average exchange rate of Rs. 85.19381633 per US Dollar is Rupee 38869.67870 . A $\$ 1$ poverty rate of $24.3 \%$ is thus obtained.

\subsubsection{Econometric techniques employed}

Remittances are an important outcome of the migration process which, being expensive, is not available to all households. A possibility therefore exists that the factors that drive the migration process and the ensuing remittances also determine the household's economic resources. It means that remittance receiving households (called the treatment group) are not randomly selected and may differ from the non-recipient households in such characteristics as risk aversion, skills or individual talent. This selection bias can seriously affect the quality of estimation. In the absence of suitable instruments, matching techniques are considered to be most appropriate for reducing this bias. Empirical analysis in this study is based on one of these techniques called the Propensity Score Matching (PSM). PSM matches treated and control or non-treated groups by comparing the conditional probabilities of participating in the treatment group based on a set of observable characteristics. These probabilities are used to construct a score called the Propensity Score, and are obtained by regressing the treatment variable on the vector of covariates using the Probit or Logit models. As only one state (treatment or nontreatment) can be observed at a given moment (Holland, 1986), therefore only average treatment effect on the treated (ATT) can be calculated as the mean effect of the paired units (Bryson, Dorsett and Purdon, 2002).

Propensity score matching requires that certain conditions be fulfilled. The common support restriction states that for each value of the observable covariates, there is a positive probability of belonging both to the treatment and control groups (Heckman, Ichimura, \& Todd, 1997). This condition improves the matching quality by ensuring sufficient overlapping in the propensity scores of the treated and control units (Becker and Ichino, 2002).

The Conditional Independence Assumption implies that given the set of observable characteristics, allocation to the treated group is random, and therefore, selection must be exclusively based on the vector of observable covariates which determine the propensity score (Rosenbaum \&Rubin, 1983; Caliendo \& Kopeinig, 2008). 
A number of matching methods exist for matching the treated and control groups based on propensity scores. These include Nearest Neighbour (NN) matching, Caliper or Radius matching, Stratification matching and kernel matching. In this study, NN, radius and Kernel matching methods are employed to obtain matching estimates. In Nearest Neighbour matching, each treatment unit is matched with its closest neighbor with similar observed characteristics. A unit is selected from the control group as a match for a unit from the treated group on the basis of nearest propensity score. These units are then used to produce an estimate of the counterfactual. The treated unit is matched with its closest neighbour. However, if the neighbour is distant, matching leads to poor estimates. This issue can be resolved by defining a maximum propensity score radius (caliper). In Radius or Caliper matching, each treated unit is matched only with the control unit whose propensity score falls within the pre-defined radius. The matching thus obtained employs the mean of all the compared units. In this study, the caliper is fixed at 0.05 .

$\mathrm{NN}$ and Radius matching are based on a limited number of control units used to construct the counterfactual. Moreover, it is difficult to a priori know the size of suitable caliper. Kernel matching, in contrast, employs more information available in the sample by using weighted means of all control units to construct the counterfactual. This non-parametric estimator matches all participating units with a weighted average of all control units. All the observations in the treated group which are inside the common support area are employed. The weights used are inversely proportional to the difference between the treated units and the control units, and the highest weight is attached to the closest units. Treated households are matched with a weighted sum of households with similar propensity scores. The Kernel estimator that uses all the data from the untreated group is known as Gaussian Kernel, while the one based on fixed bandwidth parameters is called the Epanechnikov Kernel. The choice of the bandwidth parameter in a Kernel estimation is a compromise between a small variance and an unbiased estimate of the true density function, with low bandwidth providing unbiased estimates and large bandwidth leading to a better fit (Pagan and Ullah, 1999). In this study, the Gaussian Kernel estimator is employed with a default bandwidth of 0.06 as well as a lower bandwidth of 0.01 to obtain more unbiased estimates. The PSM estimations are carried out using Stata's psmatch2 module (Leuven and Sianesi, 2012). 


\section{5. Key findings}

Table 5.5 shows the results of the four matching models for the overall and category-wise asset accumulation. The Average Treatment Effects on the Treated (ATT) for foreign remittances given in Panel I are found to be significant at the 1\% level, suggesting a substantial overall increase in the asset stock of the migrant households. Household receiving international transfers hold between 0.22 (NN matching) and 0.36 standard deviation (Kernel matching with 0.06 bandwidth) more assets compared with their non-recipient counterparts. Domestic remittances, in contrast, fail to show any significant effects on the recipient households' asset holdings, with none of the ATTs found significant at or below $10 \%$.

Table 5.5. Remittances and asset categories (Propensity Score Matching)

\begin{tabular}{lllll}
\hline \hline Assets & NN & Kernel & Kernel (b.w 0.01) & Radius \\
\hline Foreign remittances & & & & $0.338^{* * *}$ \\
Total Assets & $0.220^{* * *}$ & $0.355^{* * *}$ & $0.296^{* * *}$ & $(0.063)$ \\
& $(0.081)$ & $(0.061)$ & $(0.065)$ & $0.373^{* * *}$ \\
Housing Quality & $0.369^{* * *}$ & $0.402^{* * *}$ & $0.389^{* * *}$ & $(0.048)$ \\
& $(0.055)$ & $(0.046)$ & $(0.049)$ & $0.399^{* * *}$ \\
Consumer Durables & $0.398^{* * *}$ & $0.441^{* * *}$ & $0.415^{* * *}$ & $(0.051)$ \\
& $(0.061)$ & $(0.049)$ & $(0.052)$ & $0.153^{* *}$ \\
Productive Assets & 0.118 & $0.149^{* *}$ & 0.056 & $(0.062)$ \\
& $(0.077)$ & $(0.062)$ & $(0.065)$ & $0.655^{* * *}$ \\
Financial Assets & $0.681^{* * *}$ & $0.650^{* * *}$ & $0.591 * * *$ & $(0.080)$ \\
& $(0.098)$ & $(0.080)$ & $(0.087)$ & 0.020 \\
Domestic Remittances & & & & $(0.051)$ \\
Total Assets & 0.010 & -0.008 & 0.009 & -0.043 \\
& $(0.070)$ & $(0.049)$ & $(0.052)$ & $(0.039)$ \\
Housing Quality & 0.020 & -0.060 & -0.042 & -0.047 \\
Consumer Durables & $(0.050)$ & $(0.038)$ & $(0.040)$ & $(0.041)$ \\
Productive Assets & 0.019 & -0.059 & -0.046 & 0.019 \\
Financial Assets & $(0.052)$ & $(0.040)$ & $(0.042)$ & $(0.046)$ \\
& -0.050 & 0.016 & -0.019 & -0.055 \\
Note: Standard errors in parentheses $* * * p<0.01, * * \mathrm{p}<0.05, * \mathrm{p}<0.1$ & $(0.048)$ & $(0.070)$ \\
\hline
\end{tabular}

Similar patterns are visible for the four asset categories, where ATT for foreign remittances are found mostly significant whereas those for domestic remittances are invariably insignificant. While the holdings of all the asset categories go up among foreign remittance-receiving households, productive assets show the lowest increase. In contrast, ownership of consumer durables increases substantially. Similarly, savings in cash and gold and housing assets show remarkable increase, rising by 0.59 to 0.68 and 0.37 to 0.4 standard deviation respectively. These findings possibly reflect the long-term spending priorities of the recipient households: 
Although using remittance money for accumulating physical and human capital in order to generate future income is important, the migrant households deem it necessary to first improve their immediate living standards by acquiring durable goods and better housing, and accumulate financial assets to serve as precautionary savings. Acquisition of housing and financial assets could also result from the migrant's intention to return back home (Galor and Stark 1990, 1991).

These asset accumulation patterns can also be seen with respect to the size of remittances, with higher amounts of foreign remittances leading to greater accumulation of assets of all categories except for productive assets whose holding does not significantly differ with amounts of remittances received ${ }^{28}$. As before, the impact of domestic remittances is not significant regardless of their magnitude, except for consumer durables and productive assets whose accumulation increases with the amount of domestic transfer.

The substantially different impact of foreign and domestic remittances on the recipient households' asset accumulation presented above may be due to both the nature and magnitude of the two types of remittances, as well as the recipient households economic conditions. Households with foreign remittances are at an average more prosperous with an annual income of Rs. 356,659 compared with domestic remittance-receiving households which earn almost half as much (annual income being Rs. 179,065). The lower revenues of the domestic remittance recipients do not allow them extra leeway to buy durables or accumulate other assets compared with their non-recipient counterparts. This is however not the case with foreign remittance receiving households, as their income far exceeds those of the non-recipient ones. Moreover, the share of foreign remittances in the household income is higher at $69 \%$ compared with $58 \%$ for domestic remittances.

Most foreign remittances are sent by Pakistani migrants working in the states of the Persian Gulf on temporary job contracts. This uncertain additional source of income serves as a means for the migrant household to acquire durable assets, better transport facilities and improved housing. Domestic remittances, on the other hand, depict a behaviour similar to other, permanent sources of household income. Internal migration in Pakistan has been strong in the recent decades,

\footnotetext{
${ }^{28}$ Results available upon request.
} 
particularly from the rural to the urban areas, and the country's share of urban population, at $37 \%$, is among the highest among the countries of South Asia (World Bank, 2012). Unlike international migration to the Persian Gulf, internal migration leads to more long-lasting remittances which are consequently consumed as any other source of income.

The asset accumulation patterns of households with and without remittances also differ with respect to the place of residence. Table 5.6 and Table 5.7 respectively show the impact of remittances on assets in the urban and rural areas. Rural recipients of international transfers show a much higher rise in assets compared with urban households' (the ATT for the two groups of households' range from 0.38 to 0.43 for the rural and 0.15 to 0.21 for the urban households' respectively). In addition, the stock of productive assets among the rural recipient households increases by a substantial 0.22 standard deviations, whereas no significant increase can be discerned among urban recipients. In the villages, acquisition of productive assets such as land not only provides the households with a future stream of income but also raises the households social status.

Table 5.6. Remittances and asset categories: Urban households (Propensity Score Matching)

\begin{tabular}{lllll}
\hline \hline Assets & NN & Kernel & Kernel (b.w 0.01) & Radius \\
\hline Foreign remittances & & & & \\
Total Assets & $0.179^{*}$ & $0.214^{* *}$ & $0.147^{* *}$ & $0.213^{* *}$ \\
& $(0.097)$ & $(0.084)$ & $(0.072)$ & $(0.068)$ \\
Housing Quality & $0.163^{* *}$ & $0.247^{* * *}$ & $0.216^{* * *}$ & $0.239^{* * *}$ \\
& $(0.066)$ & $(0.059)$ & $(0.059)$ & $(0.059)$ \\
Consumer Durables & $0.276^{* * *}$ & $0.328^{* * *}$ & $0.294 * * *$ & $0.309^{* * *}$ \\
& $(0.091)$ & $(0.074)$ & $(0.075)$ & $(0.075)$ \\
Productive Assets & -0.023 & -0.048 & -0.052 & -0.048 \\
& $(0.079)$ & $(0.061)$ & $(0.063)$ & $(0.061)$ \\
Financial Assets & $0.499^{* * *}$ & $0.404^{* * *}$ & $0.502^{* * *}$ & $0.433^{* * *}$ \\
& $(0.160)$ & $(0.145)$ & $(0.128)$ & $(0.134)$ \\
Domestic Remittances & & & & \\
Total Assets & 0.012 & -0.071 & -0.072 & -0.073 \\
& $(0.088)$ & $(0.060)$ & $(0.061)$ & $(0.062)$ \\
Housing Quality & -0.056 & $-0.116^{* *}$ & $-0.132^{* *}$ & $-0.125^{* *}$ \\
Consumer Durables & $(0.061)$ & $(0.047)$ & $(0.050)$ & 0.048 \\
Productive Assets & -0.036 & $-0.138^{* *}$ & $-0.129 * *$ & $-0.136^{* *}$ \\
Financial Assets & $(0.078)$ & $(0.059)$ & $(0.063)$ & $(0.060)$ \\
& 0.018 & -0.032 & -0.054 & -0.028 \\
\hline Note: Standard & $(0.056)$ & $(0.043)$ & $(0.046)$ & $(0.043)$ \\
& $-0.268^{*}$ & -0.127 & -0.107 & -0.129 \\
& $(0.154)$ & $(0.115)$ & $(0.120)$ & $(0.115)$ \\
\hline
\end{tabular}

Note: Standard errors in parentheses $* * * \mathrm{p}<0.01, * * \mathrm{p}<0.05, * \mathrm{p}<0.1$ 
Table 5.7. Remittances and assets categories: Rural households (Propensity Score Matching)

\begin{tabular}{lllll}
\hline Assets & NN & Kernel & Kernel (b.w 0.01) & Radius \\
\hline Foreign remittances & & & & \\
Total Assets & $0.389^{* * *}$ & $0.431^{* * *}$ & $0.382^{* * *}$ & $0.389^{* * *}$ \\
& $(0.093)$ & $(0.071)$ & $(0.078)$ & $(0.076)$ \\
Housing Quality & $0.556^{* * *}$ & $0.513 * * *$ & $0.471 * * *$ & $0.481^{* * *}$ \\
& $(0.066)$ & $(0.053)$ & $(0.054)$ & $(0.054)$ \\
Consumer Durable Assets & $0.477^{* * *}$ & $0.503 * * *$ & $0.423 * * *$ & $0.446^{* * *}$ \\
& 0.072 & 0.056 & 0.058 & 0.057 \\
Productive Assets & -0.025 & $0.220^{* *}$ & 0.141 & $0.224^{* *}$ \\
& $(0.124)$ & $(0.094)$ & $(0.097)$ & $(0.094)$ \\
Financial Assets & $0.651^{* * *}$ & $0.719 * * *$ & $0.700^{* * *}$ & $0.719 * * *$ \\
& $(0.124)$ & $(.0998)$ & $(0.109)$ & $(0.100)$ \\
Domestic Remittances & & & & \\
Total Assets & -0.097 & 0.048 & 0.014 & 0.029 \\
Housing Quality & $(0.083)$ & $(0.059)$ & $(0.064)$ & $(0.060)$ \\
& -0.017 & 0.002 & -0.014 & -0.011 \\
Consumer Durable Assets & $(0.056)$ & $(0.045)$ & $(0.047)$ & $(0.045)$ \\
& 0.070 & 0.020 & -0.002 & 0.005 \\
Productive Assets & $(0.060)$ & $(0.047)$ & $(0.050)$ & $(0.048)$ \\
& 0.015 & -0.012 & -0.066 & -0.010 \\
& $(0.085)$ & $(0.069)$ & $(0.073)$ & $(0.068)$ \\
\hline
\end{tabular}

Note: Standard errors in parentheses $* * * \mathrm{p}<0.01, * * \mathrm{p}<0.05, * \mathrm{p}<0.1$

An intriguing finding is that urban recipients of internal remittances seem to possess fewer housing and consumer goods compared to the non-receiving households. This could be due to the households needing to liquidate these assets for consumption smoothing in the face of financial difficulties. It is noteworthy that at the time of the survey, households receiving domestic transfers reported deteriorating household and community economic conditions compared to the preceding year.

Recipient households living below the poverty line also differ from their non-poor recipient counterparts in their asset portfolio. Table 5.8 shows the relationship between remittances and asset indices for both the poor and non-poor households ${ }^{29}$. While remittances from within the country show no significant association with asset holdings among the non-poor households, sizeable effects could be noticed among the poor. The latter groups of households indicate a significant and positive association between remittance receipt and housing assets. Similarly, while non-poor households receiving international transfers do not show any significant appetite for productive assets, there does exist a significant relationship between remittances and productive assets among the poor households. The divergent asset accumulation patterns of poor

${ }^{29}$ Estimations were obtained using OLS due to insufficient common support for matching procedures 
households with international and domestic transfers again points to the nature of these remittances. Poor recipients of foreign remittances use them for improving their capital endowment treating the remittances as transitory income, whereas the poor households receiving domestic transfers consider them a more permanent part of the income and thus spend them for purchasing durable goods and improving housing.

Table 5.8. Remittances and asset categories: Poor and non-poor households (OLS estimates)

\begin{tabular}{lllll}
\hline \hline Assets & \multicolumn{2}{c}{ Poor } & \multicolumn{2}{c}{ Non-poor } \\
\cline { 2 - 5 } & Foreign & Domestic & Foreign & Domestic \\
Total Assets & Remittances & Remittances & Remittances & Remittances \\
\cline { 2 - 5 } No. of Obs. & $\left(0.278^{* *}\right.$ & $0.302^{* * *}$ & $0.312^{* * *}$ & 0.037 \\
R-Squared & 528 & $(0.100)$ & $(0.0500)$ & $(0.040)$ \\
Housing Quality & 0.455 & 528 & 4,579 & 4,579 \\
& 0.190 & 0.455 & 0.562 & 0.562 \\
No. of Obs. & $(0.223)$ & $0.250^{* * *}$ & $0.303 * * *$ & -0.002 \\
R-Squared & 1,483 & $(0.077)$ & $(0.039)$ & $(0.040)$ \\
Consumer Durables & 0.336 & 0.336 & 7,186 & 7,186 \\
& $0.300^{* * *}$ & 0.096 & 0.499 & 0.499 \\
No. of Obs. & $(0.092)$ & $(0.068)$ & $0.336 * * *$ & 0.016 \\
R-Squared & 1,483 & 1,483 & 7,186 & $(0.038)$ \\
Productive Assets & 0.332 & 0.332 & 0.433 & 7,186 \\
& $0.272 *$ & -0.038 & 0.0421 & -0.433 \\
No. of Obs. & $(0.154)$ & $(0.086)$ & $(0.066)$ & $(0.058)$ \\
R-Squared & 1,472 & 1,472 & 7,151 & 7,151 \\
Financial Assets & 0.134 & 0.134 & 0.327 & 0.327 \\
& $0.793 *$ & -0.087 & $0.508 * * *$ & -0.022 \\
No. of Obs. & $(0.407)$ & $(0.216)$ & $(0.085)$ & $(0.075)$ \\
R-Squared & 530 & 530 & 4,595 & 4,595 \\
Note: Standard errors in parentheses $* * * \mathrm{p}<0.01, * * \mathrm{p}<0.05, * \mathrm{p}<0.1$ & & 0.257 \\
& & & &
\end{tabular}

\subsection{Estimation quality and robustness checks}

\subsubsection{Quality and sensitivity diagnostics}

The four matching routines provide similar results for the two types of treatment groups. The full sample as well as rural, urban, poor and non-poor subsamples are individually balanced by calculating corresponding propensity scores and applying the common support. Common support is ensured by implementing the common support region and the receiving households with propensity scores greater than the maximum or lower than the minimum propensity score among the non-recipients are not considered. The balancing and sensitivity tests indicate the quality of the matches of the treatment and control groups. As reported in, tests for balance of the included covariates show a substantial bias reduction between the recipient and non-recipient groups 
across model specifications. For example, the more conservative kernel estimation with 0.01 bandwidth performs well in case of foreign remittances. The percentage reduction in standardized mean bias for all estimations ranges from $70 \%$ to $93 \%$, which is substantially above Rubin (1985)'s suggested reduction of $20 \%$. Furthermore, the post-matching pseudo $\mathrm{R}^{2}$ dropped significantly from $25 \%$ to less than $1 \%$. The p-values of the likelihood ratio tests show that the joint significance of the covariates is invariably rejected after matching where as it was never rejected prior to matching.

Conditional independence is tested through the Rosenbaum sensitivity test using Stata's Rbounds user command (DiPrete and Gangl 2004). The test gauges the robustness of the selection process to the presence of a hidden bias due to unobservable variables (Rosenbaum, 2002; Becker and Caliendo, 2007). The test uses NN matching results to draw the confidence intervals of the outcome variables for different values of Gamma $(\mathrm{G})$. Values close to 1 indicate the sensitivity of ATT to hidden bias.

Table 5.9. Rosenbaum bounds sensitivity analysis: Foreign remittances

\begin{tabular}{|c|c|c|c|c|c|c|c|}
\hline & \multirow[t]{2}{*}{$\Gamma$} & \multicolumn{2}{|c|}{$\begin{array}{l}\text { Wilcoxon's signed } \\
\text { rank test }\end{array}$} & \multicolumn{2}{|c|}{$\begin{array}{l}\text { Hodges-Lehmann } \\
\text { point estimates }\end{array}$} & \multicolumn{2}{|c|}{$\begin{array}{l}95 \% \text { confidence } \\
\text { Interval }\end{array}$} \\
\hline & & sig+ & sig- & t-hat+ & t-hat- & $\mathrm{CI}+$ & CI- \\
\hline \multirow[t]{5}{*}{ Total Assets } & 1.00 & $<.00001$ & $<.00001$ & .240419 & .240419 & .121094 & .357617 \\
\hline & 1.10 & $<.00001$ & $<.00001$ & .194471 & .283751 & .074764 & .400275 \\
\hline & 1.20 & .007109 & $<.00001$ & .153983 & .324352 & .031099 & .442484 \\
\hline & 1.30 & .033115 & $<.00001$ & .115281 & .362844 & -.008084 & .479917 \\
\hline & 1.40 & .102001 & $<.00001$ & .080977 & .394879 & -.07851 & .546403 \\
\hline \multirow[t]{6}{*}{ Housing Quality } & 1.00 & $<.00001$ & $<.00001$ & .378548 & .378548 & .270987 & .483281 \\
\hline & 1.20 & $<.00001$ & $<.00001$ & .292843 & .461637 & .183259 & .568296 \\
\hline & 1.40 & $<.00001$ & $<.00001$ & .219162 & .531553 & .108004 & 639138 \\
\hline & 1.60 & .00303 & $<.00001$ & .155215 & .592474 & .046335 & .702475 \\
\hline & 1.80 & .035509 & $<.00001$ & .102527 & .645164 & -.009502 & .75875 \\
\hline & 1.90 & .084324 & $<.00001$ & .054791 & .693272 & -.058235 & .806412 \\
\hline \multirow{6}{*}{$\begin{array}{l}\text { Consumer } \\
\text { durables }\end{array}$} & 1.00 & $<.00001$ & $<.00001$ & .407031 & .407031 & .290404 & .521224 \\
\hline & 1.20 & $<.00001$ & $<.00001$ & .313526 & .49844 & .195318 & .614026 \\
\hline & 1.40 & .000079 & $<.00001$ & .239549 & .573295 & .116772 & .69001 \\
\hline & 1.60 & .003458 & $<.00001$ & .168502 & .640049 & .045844 & .759682 \\
\hline & 1.80 & .039117 & $<.00001$ & .10994 & .69723 & -.012582 & .816559 \\
\hline & 1.90 & .091453 & $<.00001$ & .081942 & .724794 & -.042157 & .844615 \\
\hline \multirow[t]{2}{*}{ Productive Assets } & 1 & .048838 & .048838 & .104362 & .104362 & -.020244 & .25416 \\
\hline & 1.1 & .198938 & .006741 & .052532 & .163527 & -.072861 & .323542 \\
\hline \multirow[t]{6}{*}{ Financial Assets } & 1.00 & $<.00001$ & $<.00001$ & .693147 & .693147 & .509285 & .871485 \\
\hline & 1.20 & $<.00001$ & $<.00001$ & .571674 & .81482 & .381569 & .99025 \\
\hline & 1.40 & $<.00001$ & $<.00001$ & .468455 & .914063 & .275023 & 1.0924 \\
\hline & 1.60 & $<.00001$ & $<.00001$ & .376386 & .997467 & .183862 & 1.18356 \\
\hline & 1.80 & .001779 & $<.00001$ & .293893 & 1.07422 & .101471 & 1.26286 \\
\hline & 2.00 & .012777 & $<.00001$ & .229766 & 1.14006 & .03204 & 1.33219 \\
\hline
\end{tabular}


The test is performed by computing the maximum and minimum p-values using the Wilcoxon sign rank test and the Hodges-Lehman point estimates and their respective confidence intervals. An upper bound of zero or a p-value greater than 0.05 for the two suggests a critical level of $G$ at which the matching estimates are no more statistically significant. Table 5.9 reports the Rosenbaum Bounds test statistics for total assets and their subcategories with foreign remittances as the treatment variable. Rosenbaum bounds are calculated only for significant ATT estimates. The lower and upper bounds of the Hodges-Lehmann estimates (Column 4-5) and the maximum p-values for the Wilcoxon signed-rank test (Columns 3) show that the cut-off point at which the matching estimates become insignificant is 1.3 and 1.4 at the minimum respectively. This implies that the odd ratio needs to increase by at least $30 \%$ in order to render the estimation biased due to an unobservable variable. This relatively moderate likelihood suggests that the estimations are not strongly sensitive to selection bias. The causal effects of remittances on household asset accumulation can therefore be termed satisfactory.

\subsubsection{Robustness measures}

This analysis is based on various propensity matching procedures, which mainly rely on balancing the treatment and control groups. However, an overall good balancing does not necessarily imply joint balancing of all the covariates as the underlying propensity score model can be mis-specified (Hainmueller, 2012). One solution can be to integrate covariate balance into the weight function employed to adjust the control units (Hainmueller, 2012). This method, called 'Entropy balancing', can significantly improve the quality of covariate balance and allows better use of information present in the data. The method preprocesses data by adjusting weights to include the selected covariates on the known moments of the covariate distribution, thereby obtaining an exact covariate balance. Consequently, we analyze our dataset using Entropy balancing as a robustness measure. The estimations are carried out using Stata's ebalance package (Hainmueller and $\mathrm{Xu}, 2013$ ). Findings given in Table 5.10 are identical in signs and significance to the previous results obtained from other matching methods.

Table 5.10. Remittances and household assets (Entropy balancing)

\begin{tabular}{|c|c|c|c|c|c|c|}
\hline \multirow[t]{2}{*}{ Assets } & \multicolumn{2}{|c|}{ Full Sample } & \multirow{2}{*}{$\begin{array}{c}\text { Urban } \\
\text { Foreign }\end{array}$} & \multicolumn{3}{|c|}{ Rural } \\
\hline & Foreign & Domestic & & Domestic & Foreign & Domestic \\
\hline Total Assets & $\begin{array}{l}0.361 * * * \\
(0.037)\end{array}$ & $\begin{array}{l}0.001 \\
(0.033) \\
\end{array}$ & $\begin{array}{l}0.155^{* * * *} \\
(0.050)\end{array}$ & $\begin{array}{l}-0.052 \\
(0.043) \\
\end{array}$ & $\begin{array}{l}0.484 * * * \\
(0.049)\end{array}$ & $\begin{array}{l}0.025 \\
(0.047) \\
\end{array}$ \\
\hline No. of obs. & 5107 & & 2660 & & 2447 & \\
\hline
\end{tabular}




\begin{tabular}{|c|c|c|c|c|c|c|}
\hline Housing Quality & $\begin{array}{l}0.350 * * * \\
(0.032)\end{array}$ & $\begin{array}{l}-0.025 \\
(0.030) \\
\end{array}$ & $\begin{array}{l}0.232 * * * \\
(0.048)\end{array}$ & $\begin{array}{l}-0.096^{* *} \\
(0.042)\end{array}$ & $\begin{array}{l}0.493 * * * \\
(0.045)\end{array}$ & $\begin{array}{l}-0.001 \\
(0.040)\end{array}$ \\
\hline No. of obs. & 8669 & & 4287 & & 4382 & \\
\hline Consumer Durables & $\begin{array}{l}0.362 * * * \\
(0.036)\end{array}$ & $\begin{array}{l}-0.015 \\
(0.031)\end{array}$ & $\begin{array}{l}0.245 * * * \\
(0.245)\end{array}$ & $\begin{array}{l}-0.105 * * \\
(0.050)\end{array}$ & $\begin{array}{l}0.489 * * * \\
(0.048)\end{array}$ & $\begin{array}{c}0.029 \\
(0.039)\end{array}$ \\
\hline No. of obs. & 8669 & & 4287 & & 4382 & \\
\hline Productive Assets & $\begin{array}{l}0.0931 * \\
(0.049)\end{array}$ & $\begin{array}{l}0.047 \\
(0.038)\end{array}$ & $\begin{array}{l}-0.041 \\
(0.056)\end{array}$ & $\begin{array}{l}-0.001 \\
(0.038)\end{array}$ & $\begin{array}{l}0.139 * * \\
(0.074)\end{array}$ & $\begin{array}{l}(0.073) \\
(0.055)\end{array}$ \\
\hline No. of obs. & 8623 & & 4280 & & 4343 & \\
\hline Financial Assets & $\begin{array}{l}0.535 * * * \\
(0.066)\end{array}$ & $\begin{array}{l}-0.061 \\
(0.062)\end{array}$ & $\begin{array}{l}0.394 * * * \\
(0.087)\end{array}$ & $\begin{array}{l}-0.095 \\
(0.095)\end{array}$ & $\begin{array}{l}0.613 * * * \\
(0.090)\end{array}$ & $\begin{array}{l}-0.036 \\
(0.081) \\
\end{array}$ \\
\hline No. of obs. & 5125 & & 2662 & & 2463 & \\
\hline
\end{tabular}

For comparison, we also obtain the estimates using Ordinary Least Squares. The results are likewise found robust (see Table A5.14-A5.16). In addition, we test the robustness of our findings by replacing the treatment variables (amount of remittances instead of their incidence) and covariates (for example, aggregate household income in place of per capita household income). The results are again similar, and maintain the essence of the analysis.

Here a couple of caveats must be mentioned: First, asset accumulation among migrant households may in some cases also be the cause of remittance receipts. This may particularly happen if the migrant seeks to maintain his/her share in family inheritance. This possible reverse causality can not be adequately addressed in this study due to lack of suitable instruments for remittances, and may therefore cause endogeneity bias. It may however be noted that the focus of this study is mainly on the statistical significance and signs of relationship between the two types of remittances on the one hand and various asset categories on the other. As described above, results of the study are robust across a large number of model specifications, variable definitions, and parametric as well as matching techniques. We can therefore expect that the crux of our findings is intact.

Secondly, this analysis is based on a household survey that does not contain a migration module per se. Differential impacts of remittance receipt relative to that of emigration of household members or relatives can therefore not be examined. Another way in which this study would have been undertaken is to compare the two remittances recipients groups with the one receiving no remittances. However, this would lead to too little overlapping and therefore poor matching. 


\subsection{Conclusion}

This study examined wealth gains among Pakistani households resulting from international and internal transfers. The changes in asset stocks among households receiving foreign remittances were found to be substantially different from those among the recipients of domestic remittances. Not only did the foreign remittance-receiving households accumulate more assets than their nonrecipient counterparts, their acquired stock grows for all categories of assets. Migrant households accumulate productive assets such as land and livestock as well as the household's human capital. However, this increase pales in comparison with accumulation of consumer durables, housing, and financial assets. These trends are reinforced as the amounts of remittances increase. In contrast, the stock accumulation of domestic remittance-receiving households does not appear any different from the non-recipient households. Recipients of foreign and domestic remittances show similarly divergent patterns in rural and urban parts of the country. Rural recipients of international transfers acquire much more assets, including productive assets, compared with the non-recipient rural households. Similarly, poor foreign remittance receivers appear to be more keen at accumulating productive assets than the non-poor receivers, while impoverished recipients of internal transfers show more interest in acquiring consumer durables and upgrading their houses.

These findings lead to a number of implications:

First, migrant households treat foreign remittances as a mainly transitory income and therefore spend it to raise their assets and capital stock. Domestic remittances, on the other hand, are considered a permanent source of income and thereby serve more or less the same purposes as the households' other regular revenues. This corroborates the findings of previous studies such as Adams (1998) and Ahmed and Mughal (2014) which showed support for the Permanent Income Hypothesis.

A second related conclusion is that remittances serve to save for rainy days. Migrant households use foreign remittances to generate precautionary savings in cash and kind (particularly in gold). Gold jewelry has traditionally served as the savings of choice for women in South Asia, and also constitutes a major item of the dowry widely practiced in the region.

A third noteworthy implication is that even though foreign remittances raise recipient households stock of all kinds of assets, the increase in productive assets seems to be weak. This could be implied to support the argument that remittances are mostly consumed rather than invested. This 
notwithstanding, households receiving international transfers, even among the poorest strata of the society, acquire some productive assets and can therefore expect to generate future income from the investment. Moreover, not all consumer durables can entirely be counted as consumption. Sewing machines and computers can be used as capital inputs in small home-based businesses, while automobiles can transport the produce of home farms.

To sum up, remittances, especially those from abroad, raise the recipient households' short- and long-term living standards by improving the asset stock, increasing the households' physical and human capital, and generating savings. 


\section{References}

Adams, R. H. (1991). The economic uses and impact of international remittances in rural Egypt. Economic Development and Cultural Change, 695-722.

Adams, R. H. (1998). Remittances, investment and rural asset accumulation in Pakistan. Economic Development and Cultural Change 47, 155-73.

Adams , R. H., \& Cuecuecha, A. (2010a). The economic impact of international remittances on poverty and household consumption and investment in Indonesia (No. 5433). The World Bank.

Adams, R. H. \& Cuecuecha, A. (2010b). Remittances, household expenditure and investment in Guatemala. World Development, 38(11), 1626-1641.

Ahmed, J., and Mughal, M.Y. (2014) How do remittances affect household consumption patterns? Unpublished manuscript.

Amuedo-Dorantes, C., \& Pozo, S. (2011). New evidence on the role of remittances on healthcare expenditures by Mexican households'. Review of Economics of the Household, 9(1), 69-98.

Ando, A., \& Modigliani, F. (1957). Tests of the life cycle hypothesis of saving: comments and suggestions. Bulletin of the Oxford Institute of Statistics, 19(2), 99-124.

Amuedo-Dorantes, C., \& Pozo, S. (2014). When do remittances facilitate asset accumulation? The importance of remittance income uncertainty (No. 7983). IZA Discussion Paper.

Andersson, L. (2014). Migration, remittances and household welfare in Ethiopia (No. 004). United Nations University-Maastricht Economic and Social Research Institute on Innovation and Technology (MERIT).

Bryson, A., \& Dorsett, R. (2002). The use of propensity score matching in the evaluation of active labour market policies (No. 1948). National Institute of Economic and Social Research.

Becker, S. O., \& Ichino, A. (2002). Estimation of average treatment effects based on propensity scores. The stata journal, 2(4), 358-377.

Caliendo, M., \& Kopeinig, S. (2008). Some practical guidance for the implementation of propensity score matching. Journal of economic surveys, 22(1), 31-72.

Chami, R., C. Fullenkamp and S. Jahjah, 2005. Are immigrant remittance flows a source of capital for development? IMF Staff Papers, 52(1). 
Chiodi, V., Jaimovich, E., \& Montes-Rojas, G. (2012). Migration, remittances and capital accumulation: Evidence from rural Mexico. Journal of Development Studies, 48(8), 1139-1155.

Clément, M. (2011). Remittances and household expenditure patterns in Tajikistan: A propensity score matching analysis. Asian Development Review, 28(2).

Dustmann, C., \& Kirchkamp, O. (2002). The optimal migration duration and activity choice after re-migration. Journal of Development Economics, 67(2), 351-372.

Findlay, A., \& Samha, M. (1986). Return migration and urban change: a Jordanian case study. In Return Migration and Regional Economic Problems, ed. Russell King. Dover, NH: Croom Helm

Friedman, M. (1957). A theory of the consumption function. Princeton, NJ: Princeton University Press.

Galor, O., \& Stark, O. (1991). The probability of return migration, migrants work effort, and migrants performance. Journal of Development Economics, 35(2), 399-405.

Galor, O., \& Stark, O. (1990). Migrants savings, the probability of return migration and migrants performance. International Economic Review, 463-467.

Garip, F. (2014). The impact of migration and remittances on wealth accumulation and distribution in rural Thailand. Demography, 51(2), 673-698.

Gangl, M. (2004). RBOUNDS: Stata module to perform Rosenbaum sensitivity analysis for average treatment effects on the treated. Statistical Software Components.

Hainmueller, J. (2012). 'Entropy Balancing: A multivariate reweighting method to produce balanced samples in observational studies', Political Analysis, 20(1), 2546.

Hainmueller, J., \& Xu, Y. (2013). Ebalance: A Stata package for entropy balancing. Journal of Statistical Software, 54(7)

Heckman, J., Ichimura, H., \& Todd, P. (1997). Matching as an econometric evaluation estimator. Review of Economic Studies, 65(2), 261-294.

Holland, P. (1986). Statistics and causal inference. Journal of the American Statistical Association 81(396), 945-960.

Kolenikov, S., \& Angeles, G. (2009). Socioeconomic status measurement with discrete proxy variables: Is principal component analysis a reliable answer?. Review of Income and Wealth, 55(1), 128-165. 
Kolenikov, S., \& Ángeles, G. (2004). The use of discrete data in PCA: theory, simulations, and applications to socioeconomic indices. Chapel Hill: Carolina Population Center, University of North Carolina.

Lefebvre, A. (1999). Kinship, honour and money in rural Pakistan: subsistence economy and the effects of international migration. Monograph series/Nordic Institute of Asian Studies, 78.

Leland, Hayne, E. 1968. "Saving and Uncertainty: The Precautionary Demand for Saving” Quarterly Journal of Economics, 82, 465-73.

Leuven, E., \& Sianesi, B. (2012). PSMATCH2: Stata module to perform full Mahalanobis and propensity score matching, common support graphing, and covariate imbalance testing. Statistical Software Components.

Moser, C. O. (1998). The asset vulnerability framework: reassessing urban poverty reduction strategies. World development, 26(1), 1-19.

Nicholson, B., (2001). From migrant to micro-entrepreneur: Do-it-yourself development in albania, South-East Europe Review, 4(3), 39-41.

Osili, U. O. (2004). Migrants and housing investments: Theory and evidence from nigeria. Economic Development and Cultural Change, 52(4), 821-849.

Pagan, A., \& Ullah, A. (1999). Nonparametric econometrics. Cambridge university press. Prabel . K., \& Ratha, D. (2012). Impact of remittances on household income, asset and human capital: evidence from Sri Lanka. Migration and Development, 1(1), 163179.

Quisumbing, A., \& McNiven, S. (2010). Moving forward, looking back: The impact of migration and remittances on assets, consumption, and credit constraints in the rural Philippines. The Journal of Development Studies, 46(1), 91-113.

Rosenbaum, P. R., \& Rubin, D. B. (1983). The central role of the propensity score in observational studies for causal effects. Biometrika, 70(1), 41-55.

Sianesi, B. (2004). An Evaluation of the Active Labour Market Programmes in Sweden, The Review of Economics and Statistics, 86(1), 133-155.

Taylor, J. E. (1992). Remittances and inequality reconsidered: Direct, indirect, and intertemporal effects. Journal of Policy modeling, 14(2), 187-208.

Taylor, E. J. (1999). The new economics of labour migration and the role of remittances in the migration process. International migration, 37(1), 63-88.

Taylor, J. E., \& Mora, J. (2006). Does migration reshape expenditures in rural households' ?: evidence from Mexico (Vol. 3842). World Bank Publications. 
Watkins, F. (2003). Save there, eat here: Migrants, households' and community identity among Pakhtuns in northern Pakistan. Contributions to Indian Sociology, 37(1-2), 59-81

World Bank (2012). World Development Indicators. Online Database, World Bank.

Woodruff, C., Zenteno, R., 2004. Remittances and microenterprises in Mexico, working paper. Department of Economics,University of California, San Diego 


\section{Appendix}

Table A5.11. Household assets PCA: Eigen values

\begin{tabular}{|c|c|c|c|}
\hline \begin{tabular}{c}
\multicolumn{2}{c}{ Assets } \\
Coefficient
\end{tabular} & & Coefficient & Assets \\
\hline 1-Housing Quality & & 2-Consumer Assets & \\
\hline Ownership & & Iron & 0.300 \\
\hline Self owned & 0.187 & Electric Fan & 0.201 \\
\hline Hired & -0.034 & Sewing machine & 0.248 \\
\hline No. of Rooms & & Radio & 0.086 \\
\hline -One & -0.209 & Chair & 0.280 \\
\hline -Two & -0.027 & Watch & 0.238 \\
\hline -Three & 0.103 & TV & 0.296 \\
\hline -Four & 0.199 & VCP & 0.163 \\
\hline -Five or more & 0.321 & Refrigerator & 0.324 \\
\hline Roof Material & & Air Cooler & 0.178 \\
\hline -Other & -0.279 & Air Conditioner & 0.209 \\
\hline -Wood/Bamboo & -0.018 & Computer & 0.225 \\
\hline -Steel/Cement sheets & 0.121 & Bicycle & 0.019 \\
\hline$-\mathrm{RCC} / \mathrm{RBC}$ & 0.278 & Motorbike & 0.187 \\
\hline Wall Material & & Car & 0.188 \\
\hline -Other Stone Wood & -0.732 & Mobile & 0.234 \\
\hline -Mud Bricks/Blocks & -0.327 & Cooking Range & 0.155 \\
\hline -Burnt bricks/Blocks & 0.215 & Burner & 0.261 \\
\hline Source of drinking water & & Washing Machine & 0.323 \\
\hline -Other (tanker, mineral, other) & -0.719 & Eigen value & 5.348 \\
\hline -River/stream & -0.488 & Proportion & 0.282 \\
\hline -Outdoor tap & -0.371 & & \\
\hline -Well (open/closed) & -0.291 & 3-Productive Assets & \\
\hline -Hand pump & -0.137 & Tractor & \\
\hline -Motor pump & 0.085 & -No & -0.145 \\
\hline -Piped water & 0.422 & -Yes & 0.828 \\
\hline Toilet type & & Commercial Building & \\
\hline No Toilet & -0.648 & -No & -0.059 \\
\hline -Other & -0.411 & -Yes & 0.281 \\
\hline -Pit latrine & -0.304 & Non-Agricultural Land & \\
\hline -Dry raised latrine & -0.192 & -No & -0.088 \\
\hline -Flush connected to open drain & -0.059 & -Yes & 0.481 \\
\hline -flush connected to tank & 0.190 & Agricultural Land & \\
\hline -Flush connected to sewerage & 0.591 & -No & -0.300 \\
\hline Cooking fuel & & -Yes & 0.598 \\
\hline -Other & -0.588 & Livestock & \\
\hline -Dung cake & -0.381 & -No & -0.280 \\
\hline -Wood & -0.096 & -Yes & 0.556 \\
\hline -Gas & 0.332 & -Number of Schooling & 0.124 \\
\hline Lighting Source & & -Average Education & 0.068 \\
\hline -Other (Gas, Wood, Candle, other) & -0.836 & Eigen value & 2.373 \\
\hline -Kerosene oil / diesel / petrol & -0.564 & Proportion & 0.339 \\
\hline -Electricity & 0.067 & & \\
\hline Telephone & & Supply Drinking Water & \\
\hline -None & -0.456 & -Far $(15-60)$ & -0.639 \\
\hline -Mobile & 0.092 & -Near (0-14) & 0.048 \\
\hline \multirow[t]{2}{*}{-Landline and mobile } & 0.684 & Eigen value & 3.820 \\
\hline & & Proportion & 0.382 \\
\hline
\end{tabular}




\section{Table A5.12. Summary statistics}

\begin{tabular}{llc}
\hline Variable & Variable Description & Mean \\
\hline Foreign Remittances & $\begin{array}{l}\text { Dummy variable, takes the value of 1 if any member of the } \\
\text { household received remittances from abroad during last 1 year, 0 } \\
\text { otherwise }\end{array}$ & 054 \\
\hline Domestic Remittances & $\begin{array}{l}\text { Dummy variable, takes the value of 1 if any member of the } \\
\text { household received remittances inside Pakistan during last 1 year, 0 } \\
\text { otherwise }\end{array}$ & 0.107 \\
\hline Income per capita (in log) & Income per capita includes remittances income & 6.38 \\
\hline Household size & Total number of family members in the household & 0.50 \\
\hline Dependency Ratio & Share of members ages under 18 and above 65 in the household & 46.3 \\
\hline Age of head & Age of the households head in completed years & 0.09 \\
\hline Sex of head & $\begin{array}{l}\text { Dummy variable, takes the value of 1 if the household head is a } \\
\text { female, 0 otherwise }\end{array}$ & 0.92 \\
\hline Marital status of head & $\begin{array}{l}\text { Dummy variable, takes the value of 1 if the household head is } \\
\text { married, 0 otherwise }\end{array}$ & 0.81 \\
\hline Work status of head & $\begin{array}{l}\text { Dummy variable, takes the value of 1 if the household head is } \\
\text { employed, 0 otherwise }\end{array}$ & 0.30 \\
\hline Education of head & Number of years of schooling received by the household head & 2.30 \\
\hline $\begin{array}{l}\text { Household economic } \\
\text { condition }\end{array}$ & Current situation of household as compare to previous year & -0.21 \\
\hline Local economic condition & Current condition of the area as compare to previous year & -0.32 \\
\hline Region, & $\begin{array}{l}\text { Dummy variable, takes the value of 1 if the household resides in } \\
\text { rural area, 0 otherwise }\end{array}$ & 0.34 \\
\hline Province & $\begin{array}{l}\text { Takes the value of 1 if remittance recipient household lives in Sindh, } \\
\text { KPK, Baluchistan otherwise 0 }\end{array}$ & 0.41 \\
\hline \hline
\end{tabular}


Table A5.13. Quality of Matching Indicators

\begin{tabular}{|c|c|c|c|c|c|c|c|c|}
\hline & Total assets & $\begin{array}{l}\text { Consumer } \\
\text { durable/Housing } \\
\text { quality }\end{array}$ & $\begin{array}{l}\text { Productive } \\
\text { assets }\end{array}$ & $\begin{array}{l}\text { Financial } \\
\text { assets }\end{array}$ & Total assets & $\begin{array}{l}\text { Consumer } \\
\text { durable/Housing } \\
\text { quality }\end{array}$ & $\begin{array}{l}\text { Productive } \\
\text { assets }\end{array}$ & $\begin{array}{l}\text { Financial } \\
\text { assets }\end{array}$ \\
\hline Test indicator & \multicolumn{4}{|c|}{ Foreign Remittances } & \multicolumn{4}{|c|}{ "Domestic Remittances } \\
\hline \multicolumn{9}{|l|}{ Before Matching } \\
\hline Mean absolute bias & 41.14 & 39.48 & 39.63 & 40.84 & 31.76 & 32.80 & 32.96 & 31.54 \\
\hline Pseudo $R^{2}$ & 0.255 & 0.242 & 0.242 & 0.254 & 0.150 & 0.158 & 0.159 & 0.149 \\
\hline$L R \chi^{2}(P$-value $)$ & 0.000 & 0.000 & 0.000 & 0.000 & 0.016 & 0.000 & 0.000 & 0.000 \\
\hline \multicolumn{9}{|l|}{$\begin{array}{l}\text { After matching } \\
\text {-Nearest neighbor } \\
\text { matching }\end{array}$} \\
\hline Mean absolute bias & 5.95 & 3.97 & 4.46 & 4.56 & 9.25 & 4.85 & 6.33 & 6.79 \\
\hline Pseudo $R^{2}$ & 0.015 & 0.004 & 0.006 & 0.007 & 0.016 & 0.004 & 0.008 & 0.007 \\
\hline$L R \chi^{2}(P$-value $)$ & 0.301 & 0.983 & 0.887 & 0.936 & 0.242 & 0.828 & 0.347 & 0.885 \\
\hline \multicolumn{9}{|l|}{$\begin{array}{l}\text {-Kernel based } \\
\text { matching }\end{array}$} \\
\hline Mean absolute bias & 6.82 & 7.27 & 7.38 & 6.75 & 5.71 & 5.86 & 5.85 & 5.73 \\
\hline Pseudo $R^{2}$ & 0.011 & 0.010 & 0.010 & 0.011 & 0.004 & 0.005 & 0.005 & 0.004 \\
\hline$L R \chi^{2}(P$-value $)$ & 0.643 & 0.442 & 0.412 & 0.650 & 0.980 & 0.768 & 0.775 & 0.979 \\
\hline \multicolumn{9}{|l|}{$\begin{array}{l}\text {-Kernel based } \\
\text { matching (b.w 0.01) }\end{array}$} \\
\hline Mean absolute bias & 3.42 & 2.96 & 2.71 & 4.07 & 5.87 & 5.24 & 6.20 & 6.36 \\
\hline Pseudo $R^{2}$ & 0.006 & 0.005 & 0.004 & 0.006 & 0.005 & 0.004 & 0.006 & 0.006 \\
\hline$L R \chi^{2}(P$-value $)$ & 0.930 & 0.946 & 0.978 & 0.943 & 0.959 & 0.862 & 0.598 & 0.937 \\
\hline \multicolumn{9}{|l|}{-Radius matching } \\
\hline Mean absolute bias & 4.22 & 4.04 & 7.73 & 7.17 & 4.84 & 5.07 & 6.12 & 6.04 \\
\hline Pseudo $R^{2}$ & 0.005 & 0.005 & 0.011 & 0.011 & 0.003 & 0.004 & 0.005 & 0.005 \\
\hline$L R \chi^{2}(P$-value $)$ & 0.963 & 0.908 & 0.331 & 0.577 & 0.995 & 0.888 & 0.673 & 0.957 \\
\hline
\end{tabular}


Table A5.14. Remittances and asset categories (OLS estimates)

\begin{tabular}{|c|c|c|c|c|c|}
\hline VARIABLES & $\begin{array}{c}\text { (1) } \\
\text { Total Assets } \\
\end{array}$ & $\begin{array}{l}\qquad(2) \\
\text { Productive } \\
\text { Assets }\end{array}$ & $\begin{array}{l}\quad(3) \\
\text { Housing } \\
\text { Quality } \\
\end{array}$ & $\begin{array}{l}\quad(4) \\
\text { Consumer } \\
\text { Durables } \\
\end{array}$ & $\begin{array}{l}\quad(6) \\
\text { Financial } \\
\text { Assets } \\
\end{array}$ \\
\hline Income per capita & $\begin{array}{l}0.105^{* * * *} \\
(0.0171)\end{array}$ & $\begin{array}{l}-6.14 \mathrm{e}-06 \\
(0.0136)\end{array}$ & $\begin{array}{c}0.0782 * * * \\
(0.0100)\end{array}$ & $\begin{array}{c}0.124 * * * \\
(0.0149)\end{array}$ & $\begin{array}{c}0.173 * * * \\
(0.0293)\end{array}$ \\
\hline Foreign remittances & $\begin{array}{c}0.338 * * * \\
(0.0486)\end{array}$ & $\begin{array}{c}0.112 * \\
(0.0635)\end{array}$ & $\begin{array}{l}0.322 * * * \\
(0.0398)\end{array}$ & $\begin{array}{c}0.378 * * * \\
(0.0424)\end{array}$ & $\begin{array}{c}0.553 * * * \\
(0.0841)\end{array}$ \\
\hline Domestic remittances & $\begin{array}{l}0.0708^{*} \\
(0.0377)\end{array}$ & $\begin{array}{l}0.00310 \\
(0.0524)\end{array}$ & $\begin{array}{c}0.0405 \\
(0.0381)\end{array}$ & $\begin{array}{c}0.0393 \\
(0.0360)\end{array}$ & $\begin{array}{l}-0.0136 \\
(0.0725)\end{array}$ \\
\hline Household size & $\begin{array}{c}0.0351 * * * \\
(0.00421)\end{array}$ & $\begin{array}{l}0.0841 * * * \\
(0.00506)\end{array}$ & $\begin{array}{c}0.0120 * * * \\
(0.00372)\end{array}$ & $\begin{array}{c}0.0388 * * * \\
(0.00377)\end{array}$ & $\begin{array}{l}0.0556^{* * * *} \\
(0.00684)\end{array}$ \\
\hline Sex of head & $\begin{array}{l}0.157^{* *} \\
(0.0623)\end{array}$ & $\begin{array}{c}-0.166 * * * \\
(0.0632)\end{array}$ & $\begin{array}{l}0.201 * * * \\
(0.0475)\end{array}$ & $\begin{array}{c}0.199 * * * \\
(0.0503)\end{array}$ & $\begin{array}{c}0.0690 \\
(0.0999)\end{array}$ \\
\hline Age of head & $\begin{array}{c}0.0230^{* * * *} \\
(0.00548)\end{array}$ & $\begin{array}{l}-0.00854 \\
(0.00567)\end{array}$ & $\begin{array}{c}0.0228 * * * \\
(0.00408)\end{array}$ & $\begin{array}{c}0.0306 * * * \\
(0.00442)\end{array}$ & $\begin{array}{c}0.00729 \\
(0.00928)\end{array}$ \\
\hline Age of head square & $\begin{array}{c}-0.000120 * * \\
(5.59 \mathrm{e}-05)\end{array}$ & $\begin{array}{c}0.000216^{* * * *} \\
(5.94 \mathrm{e}-05)\end{array}$ & $\begin{array}{c}0.000140 * * * \\
(4.08 \mathrm{e}-05)\end{array}$ & $\begin{array}{c}-0.000217 * * * \\
(4.63 \mathrm{e}-05)\end{array}$ & $\begin{array}{c}4.16 \mathrm{e}-05 \\
(9.54 \mathrm{e}-05)\end{array}$ \\
\hline Dependency ratio & $\begin{array}{c}-0.616 * * * \\
(0.0575)\end{array}$ & $\begin{array}{c}-0.599 * * * \\
(0.0623)\end{array}$ & $\begin{array}{c}-0.281 * * * \\
(0.0381)\end{array}$ & $\begin{array}{c}-0.315 * * * \\
(0.0444)\end{array}$ & $\begin{array}{c}-0.339 * * * \\
(0.0904)\end{array}$ \\
\hline Education head & $\begin{array}{l}0.211 * * * \\
(0.00979)\end{array}$ & $\begin{array}{c}0.0785^{* * * *} \\
(0.0104)\end{array}$ & $\begin{array}{l}0.130 * * * \\
(0.00848)\end{array}$ & $\begin{array}{l}0.201 * * * \\
(0.00889)\end{array}$ & $\begin{array}{l}0.210 * * * \\
(0.0167)\end{array}$ \\
\hline Work head & $\begin{array}{c}-0.218 * * * \\
(0.0412)\end{array}$ & $\begin{array}{l}0.190 * * * \\
(0.0455)\end{array}$ & $\begin{array}{c}-0.104 * * * \\
(0.0329)\end{array}$ & $\begin{array}{c}-0.190 * * * \\
(0.0327)\end{array}$ & $\begin{array}{c}-0.245^{* * * *} \\
(0.0793)\end{array}$ \\
\hline Local Economic condition & $\begin{array}{l}0.118 * * * \\
(0.0192)\end{array}$ & $\begin{array}{c}0.245 * * * \\
(0.0209)\end{array}$ & $\begin{array}{l}0.0342 * \\
(0.0177)\end{array}$ & $\begin{array}{c}0.190 * * * \\
(0.0175)\end{array}$ & $\begin{array}{c}0.281 * * * \\
(0.0288)\end{array}$ \\
\hline HH economic condition & $\begin{array}{c}0.0627 * * \\
(0.0271)\end{array}$ & $\begin{array}{l}-0.0397 \\
(0.0274)\end{array}$ & $\begin{array}{l}0.0517 * * \\
(0.0214)\end{array}$ & $\begin{array}{c}0.0616^{* * *} \\
(0.0207)\end{array}$ & $\begin{array}{c}0.0359 \\
(0.0401)\end{array}$ \\
\hline Province & $\begin{array}{c}-0.203 * * * \\
(0.0355)\end{array}$ & $\begin{array}{c}-0.361 * * * \\
(0.0345)\end{array}$ & $\begin{array}{c}-0.0875^{* *} \\
(0.0382)\end{array}$ & $\begin{array}{c}-0.258 * * * \\
(0.0315)\end{array}$ & $\begin{array}{c}-0.453 * * * \\
(0.0503)\end{array}$ \\
\hline Region & $\begin{array}{c}0.844 * * * \\
(0.0358)\end{array}$ & $\begin{array}{c}-0.819^{* * *} \\
(0.0360)\end{array}$ & $\begin{array}{l}1.018 * * * \\
(0.0382)\end{array}$ & $\begin{array}{c}0.677 * * * \\
(0.0306)\end{array}$ & $\begin{array}{c}0.0818 \\
(0.0510)\end{array}$ \\
\hline Constant & $\begin{array}{c}-2.221 * * * \\
(0.230)\end{array}$ & $\begin{array}{l}0.0153 \\
(0.190)\end{array}$ & $\begin{array}{c}-1.760 * * * \\
(0.141)\end{array}$ & $\begin{array}{c}-2.379 * * * \\
(0.187)\end{array}$ & $\begin{array}{c}8.834 * * * \\
(0.368)\end{array}$ \\
\hline Observations & 5,107 & 8,623 & 8,669 & 8,669 & 5,125 \\
\hline R-squared & 0.577 & 0.284 & 0.508 & 0.476 & 0.278 \\
\hline
\end{tabular}

Standard errors in parentheses

$* * * \mathrm{p}<0.01, * * \mathrm{p}<0.05,{ }^{*} \mathrm{p}<0.1$ 
Table A5.15. Remittances and asset categories: Urban households (OLS estimates)

\begin{tabular}{|c|c|c|c|c|c|}
\hline VARIABLES & $\begin{array}{c}(1) \\
\text { Total Assets }\end{array}$ & $\begin{array}{l}\quad(2) \\
\text { Productive } \\
\text { Assets }\end{array}$ & $\begin{array}{l}\quad(3) \\
\text { Housing } \\
\text { Quality } \\
\end{array}$ & $\begin{array}{l}\quad(4) \\
\text { Consumer } \\
\text { Durables } \\
\end{array}$ & $\begin{array}{l}\quad(6) \\
\text { Financial } \\
\text { Assets }\end{array}$ \\
\hline Income per capita & $\begin{array}{l}0.126 * * * \\
(0.0272)\end{array}$ & $\begin{array}{l}-0.0195 * \\
(0.0105)\end{array}$ & $\begin{array}{c}0.0999 * * * \\
(0.0167)\end{array}$ & $\begin{array}{l}0.150 * * * \\
(0.0249)\end{array}$ & $\begin{array}{l}0.218^{* * *} \\
(0.0515)\end{array}$ \\
\hline Foreign remittances & $\begin{array}{r}0.0935 * * \\
(0.0471)\end{array}$ & $\begin{array}{c}0.0278 \\
(0.0633)\end{array}$ & $\begin{array}{c}0.0877 \\
(0.0610)\end{array}$ & $\begin{array}{l}0.173 * * * \\
(0.0543)\end{array}$ & $\begin{array}{c}0.387 * * * \\
(0.139)\end{array}$ \\
\hline Domestic remittances & $\begin{array}{l}-0.0790 \\
(0.0534)\end{array}$ & $\begin{array}{l}-0.00672 \\
(0.0424)\end{array}$ & $\begin{array}{l}-0.135 * * \\
(0.0583)\end{array}$ & $\begin{array}{c}-0.109 * * \\
(0.0550)\end{array}$ & $\begin{array}{c}-0.116 \\
(0.0997)\end{array}$ \\
\hline Household size & $\begin{array}{c}0.0258^{* * * *} \\
(0.00593)\end{array}$ & $\begin{array}{c}0.0555^{* * *} \\
(0.00542)\end{array}$ & $\begin{array}{l}-0.000195 \\
(0.00606)\end{array}$ & $\begin{array}{c}0.0354 * * * \\
(0.00643)\end{array}$ & $\begin{array}{l}0.0298 * * \\
(0.0121)\end{array}$ \\
\hline Sex of head & $\begin{array}{l}0.145^{* *} \\
(0.0707)\end{array}$ & $\begin{array}{l}-0.0382 \\
(0.0476)\end{array}$ & $\begin{array}{c}0.112^{*} \\
(0.0639)\end{array}$ & $\begin{array}{c}0.211^{* * * *} \\
(0.0786)\end{array}$ & $\begin{array}{c}0.217 \\
(0.145)\end{array}$ \\
\hline Age of head & $\begin{array}{c}0.0312 * * * \\
(0.00751)\end{array}$ & $\begin{array}{l}-0.0117 * * \\
(0.00503)\end{array}$ & $\begin{array}{c}0.0181 * * * \\
(0.00645)\end{array}$ & $\begin{array}{r}0.0373 * * * \\
(0.00737)\end{array}$ & $\begin{array}{c}0.0155 \\
(0.0153)\end{array}$ \\
\hline Age of head square & $\begin{array}{c}0.000210 * * * \\
(7.75 \mathrm{e}-05)\end{array}$ & $\begin{array}{c}0.000200 * * * \\
(5.17 \mathrm{e}-05)\end{array}$ & $\begin{array}{c}-0.000108^{*} \\
(6.45 \mathrm{e}-05)\end{array}$ & $\begin{array}{c}-0.000280 * * * \\
(7.63 \mathrm{e}-05)\end{array}$ & $\begin{array}{c}-2.49 \mathrm{e}-05 \\
(0.000159)\end{array}$ \\
\hline Dependency ratio & $\begin{array}{c}-0.511 * * * \\
(0.0545)\end{array}$ & $\begin{array}{c}-0.553 * * * \\
(0.0436)\end{array}$ & $\begin{array}{c}-0.191 * * * \\
(0.0504)\end{array}$ & $\begin{array}{c}-0.177 * * * \\
(0.0579)\end{array}$ & $\begin{array}{l}-0.152 \\
(0.133)\end{array}$ \\
\hline Education head & $\begin{array}{c}0.206 * * * \\
(0.0142)\end{array}$ & $\begin{array}{c}0.0837 * * * \\
(0.0103)\end{array}$ & $\begin{array}{l}0.128 * * * \\
(0.0131)\end{array}$ & $\begin{array}{c}0.214 * * * \\
(0.0137)\end{array}$ & $\begin{array}{l}0.218^{* * *} \\
(0.0274)\end{array}$ \\
\hline Work head & $\begin{array}{c}-0.171 * * * \\
(0.0447)\end{array}$ & $\begin{array}{l}-0.0532 * \\
(0.0318)\end{array}$ & $\begin{array}{c}-0.0874 * * \\
(0.0427)\end{array}$ & $\begin{array}{c}-0.140 * * * \\
(0.0465)\end{array}$ & $\begin{array}{l}-0.160 \\
(0.109)\end{array}$ \\
\hline Local Economic condition & $\begin{array}{c}0.0588^{* * * *} \\
(0.0222)\end{array}$ & $\begin{array}{l}0.106 * * * \\
(0.0168)\end{array}$ & $\begin{array}{l}-0.0188 \\
(0.0211)\end{array}$ & $\begin{array}{c}0.146^{* * * *} \\
(0.0229)\end{array}$ & $\begin{array}{r}0.245^{* * * *} \\
(0.0442)\end{array}$ \\
\hline HH economic condition & $\begin{array}{l}0.0517^{*} \\
(0.0272)\end{array}$ & $\begin{array}{c}0.0143 \\
(0.0216)\end{array}$ & $\begin{array}{l}-0.0137 \\
(0.0252)\end{array}$ & $\begin{array}{c}0.0403 \\
(0.0247)\end{array}$ & $\begin{array}{c}0.0893 \\
(0.0680)\end{array}$ \\
\hline Province & $\begin{array}{c}-0.146 * * * \\
(0.0462)\end{array}$ & $\begin{array}{c}-0.166 * * * \\
(0.0284)\end{array}$ & $\begin{array}{c}0.0562 \\
(0.0538)\end{array}$ & $\begin{array}{c}-0.185 * * * \\
(0.0441)\end{array}$ & $\begin{array}{c}-0.498^{* * * *} \\
(0.0829)\end{array}$ \\
\hline Constant & $\begin{array}{c}-1.797 * * * \\
(0.329)\end{array}$ & $\begin{array}{l}-0.179 \\
(0.147)\end{array}$ & $\begin{array}{c}-0.859 * * * \\
(0.228)\end{array}$ & $\begin{array}{c}-2.283 * * * \\
(0.304)\end{array}$ & $\begin{array}{c}8.230 * * * \\
(0.660)\end{array}$ \\
\hline $\begin{array}{l}\text { Observations } \\
\text { R-squared }\end{array}$ & $\begin{array}{l}2,660 \\
0.403\end{array}$ & $\begin{array}{l}4,280 \\
0.199\end{array}$ & $\begin{array}{l}4,287 \\
0.168\end{array}$ & $\begin{array}{l}4,287 \\
0.343\end{array}$ & $\begin{array}{l}2,662 \\
0.275\end{array}$ \\
\hline
\end{tabular}

Standard errors in parentheses $* * * \mathrm{p}<0.01, * * \mathrm{p}<0.05, * \mathrm{p}<0.1$ 
Table A5.16. Remittances and assets categories: Rural households (OLS estimates)

\begin{tabular}{|c|c|c|c|c|c|}
\hline VARIABLES & $\begin{array}{c}(1) \\
\text { Total } \\
\text { Assets }\end{array}$ & $\begin{array}{c}(2) \\
\text { Productive } \\
\text { Assets }\end{array}$ & $\begin{array}{c}\text { (3) } \\
\text { Housing } \\
\text { Quality } \\
\end{array}$ & $\begin{array}{c}\text { (4) } \\
\text { Consumer } \\
\text { Durables }\end{array}$ & $\begin{array}{c}\text { (6) } \\
\text { Financial } \\
\text { Assets }\end{array}$ \\
\hline Income per capita & $\begin{array}{c}0.0899 * * * \\
(0.0213)\end{array}$ & $\begin{array}{l}0.00596 \\
(0.0219)\end{array}$ & $\begin{array}{c}0.0619^{* * * *} \\
(0.0123)\end{array}$ & $\begin{array}{l}0.107 * * * \\
(0.0180)\end{array}$ & $\begin{array}{l}0.142 * * * \\
(0.0337)\end{array}$ \\
\hline Foreign remittances & $\begin{array}{c}0.470^{* * * *} \\
(0.0652)\end{array}$ & $\begin{array}{c}0.162 * \\
(0.0888)\end{array}$ & $\begin{array}{c}0.447 * * * \\
(0.0476)\end{array}$ & $\begin{array}{l}0.490 * * * \\
(0.0547)\end{array}$ & $\begin{array}{c}0.641 * * * \\
(0.104)\end{array}$ \\
\hline Domestic remittances & $\begin{array}{l}0.129 * * * \\
(0.0472)\end{array}$ & $\begin{array}{c}0.0326 \\
(0.0739)\end{array}$ & $\begin{array}{l}0.0881^{*} \\
(0.0476)\end{array}$ & $\begin{array}{l}0.0924 * * \\
(0.0466)\end{array}$ & $\begin{array}{c}0.0492 \\
(0.0922)\end{array}$ \\
\hline Household size & $\begin{array}{c}0.0443^{* * * *} \\
(0.00598)\end{array}$ & $\begin{array}{l}0.102 * * * \\
(0.00739)\end{array}$ & $\begin{array}{l}0.0243 * * * \\
(0.00438)\end{array}$ & $\begin{array}{l}0.0448 * * * * \\
(0.00501)\end{array}$ & $\begin{array}{r}0.0737 * * * \\
(0.00802)\end{array}$ \\
\hline Sex of head & $\begin{array}{l}0.193 * * \\
(0.0976)\end{array}$ & $\begin{array}{c}-0.240 * * \\
(0.109)\end{array}$ & $\begin{array}{l}0.290 * * * \\
(0.0661)\end{array}$ & $\begin{array}{l}0.202 * * * \\
(0.0720)\end{array}$ & $\begin{array}{l}-0.0244 \\
(0.143)\end{array}$ \\
\hline Age of head & $\begin{array}{c}0.0139 * \\
(0.00774)\end{array}$ & $\begin{array}{c}-0.0101 \\
(0.00855)\end{array}$ & $\begin{array}{c}0.0227 * * * \\
(0.00505)\end{array}$ & $\begin{array}{c}0.0249 * * * \\
(0.00560)\end{array}$ & $\begin{array}{c}0.000663 \\
(0.0115)\end{array}$ \\
\hline Age of head square & $\begin{array}{l}-2.25 \mathrm{e}-05 \\
(7.95 \mathrm{e}-05)\end{array}$ & $\begin{array}{c}0.000252^{* * *} \\
(9.14 \mathrm{e}-05)\end{array}$ & $\begin{array}{c}-0.000132 * * * \\
(5.11 \mathrm{e}-05)\end{array}$ & $\begin{array}{c}-0.000166^{* * *} \\
(6.00 \mathrm{e}-05)\end{array}$ & $\begin{array}{c}9.37 \mathrm{e}-05 \\
(0.000117)\end{array}$ \\
\hline Dependency ratio & $\begin{array}{c}-0.699 * * * \\
(0.100)\end{array}$ & $\begin{array}{c}-0.614 * * * \\
(0.109)\end{array}$ & $\begin{array}{c}-0.358 * * * \\
(0.0534)\end{array}$ & $\begin{array}{c}-0.419 * * * \\
(0.0677)\end{array}$ & $\begin{array}{c}-0.502 * * * \\
(0.123)\end{array}$ \\
\hline Education head & $\begin{array}{l}0.213 * * * \\
(0.0130)\end{array}$ & $\begin{array}{c}0.0724 * * * \\
(0.0161)\end{array}$ & $\begin{array}{l}0.128 * * * \\
(0.0108)\end{array}$ & $\begin{array}{c}0.190 * * * \\
(0.0114)\end{array}$ & $\begin{array}{c}0.195^{* * *} \\
(0.0208)\end{array}$ \\
\hline Work head & $\begin{array}{c}-0.283 * * * \\
(0.0657)\end{array}$ & $\begin{array}{l}0.338 * * * * \\
(0.0788)\end{array}$ & $\begin{array}{c}-0.144 * * * \\
(0.0465)\end{array}$ & $\begin{array}{c}-0.241 * * * \\
(0.0478)\end{array}$ & $\begin{array}{c}-0.317 * * * \\
(0.111)\end{array}$ \\
\hline Local Economic condition & $\begin{array}{c}0.167 * * * \\
(0.0291)\end{array}$ & $\begin{array}{c}0.345^{* * * *} \\
(0.0336)\end{array}$ & $\begin{array}{c}0.0700 * * * \\
(0.0251)\end{array}$ & $\begin{array}{l}0.220 * * * \\
(0.0253)\end{array}$ & $\begin{array}{l}0.310 * * * \\
(0.0385)\end{array}$ \\
\hline HH economic condition & $\begin{array}{c}0.0860 * * \\
(0.0423)\end{array}$ & $\begin{array}{l}-0.0574 \\
(0.0432)\end{array}$ & $\begin{array}{l}0.117 * * * \\
(0.0310)\end{array}$ & $\begin{array}{c}0.0871 * * * \\
(0.0308)\end{array}$ & $\begin{array}{l}-0.0102 \\
(0.0477)\end{array}$ \\
\hline Province & $\begin{array}{c}-0.282 * * * \\
(0.0514)\end{array}$ & $\begin{array}{c}-0.517 * * * \\
(0.0563)\end{array}$ & $\begin{array}{c}-0.230 * * * \\
(0.0517)\end{array}$ & $\begin{array}{c}-0.335 * * * \\
(0.0433)\end{array}$ & $\begin{array}{c}-0.435^{* * *} \\
(0.0600)\end{array}$ \\
\hline Constant & $\begin{array}{c}-1.828 * * * \\
(0.312)\end{array}$ & $\begin{array}{l}-0.199 \\
(0.300)\end{array}$ & $\begin{array}{c}-1.553 * * * \\
(0.178)\end{array}$ & $\begin{array}{c}-1.953 * * * \\
(0.230)\end{array}$ & $\begin{array}{c}9.365 * * * \\
(0.427)\end{array}$ \\
\hline Observations & 2,447 & 4,343 & 4,382 & 4,382 & 2,463 \\
\hline R-squared & 0.389 & 0.206 & 0.233 & 0.342 & 0.279 \\
\hline
\end{tabular}

Standard errors in parentheses

$* * * \mathrm{p}<0.01, * * \mathrm{p}<0.05, * \mathrm{p}<0.1$ 


\section{Chapter 6 : Conclusion}

This thesis began by asking some questions regarding the nature of migrant remittances and their impacts on the Pakistani economy. In the preceding chapters, we carried out empirical studies to find answers for these questions. In Chapter 2, we focused on the stability, cyclicality and stabilization properties of remittances, and compared them with the properties of foreign direct inflows and foreign aid. We found that remittances are the most stable of the three types of financial flows. Moreover, they show a countercyclical and stabilizing behaviour. In contrast, foreign aid appears to be acyclical and stabilizing, whereas FDI emerges as pro-cyclical and destabilizing. We found that remittances to Pakistan do not commove with sending-country output and therefore mainly follow the home-country business cycle.

In chapter 3, we studied the impact of transaction costs on the amount of foreign remittances sent. We found that lower transaction costs are associated with high remittance inflows, indicating that when the cost of remitting is high, migrants either refrain from sending money home or use informal channels to remit (hundi or hawala, by hand, through friends, etc). These decisions can be understood in light of migrant networks and improvements in home and host country financial services.

Chapter 4 investigated the differential household consumption patterns resulting from foreign and domestic remittances by using a large representative household survey from Pakistan. We found that foreign remittances lead to significant consumption changes. They do not raise the budget share on consumer goods and recreation but substantially enhance the allocation on education. Households receiving domestic remittances also show a strong focus on human capital with significantly higher shares of health and education. We found that poor recipients of international transfers spend proportionally more on food compared with their non-recipient counterparts, whereas education and health budget shares are not much different. 
In the last empirical part, we analyzed the asset accumulation patterns of the recipients of foreign and domestic remittances. We found that foreign remittances lead to a substantial increase in household assets while no significant change results from domestic remittances. Households receiving foreign remittances own greater stock of assets of all kinds, even though the increase in their productive assets is less substantial. Moreover, rural and poor recipients of foreign remittances hold more assets than their non-recipient counterparts. We also found that asset accumulation increases with the amount of money remitted from abroad.

These empirical analyses lead to a number of implications. At the macro level, the stable and countercyclical nature of international remittances signals low risk for the policymakers for relying on remittances to cover the country's chronic current account deficits. It also suggests however that risks to the country's macroeconomic stability can be caused by the inflow of international remittances.

Secondly, given the role of transaction costs in determining the role of remittance inflows, the policies that aim to facilitate remittances need to focus on reducing the cost of remitting by increasing access to financial services in the remote areas through innovations such as branchless banking. Reduction of costs will thus not only increase the volume of remittances but will also enhance financial inclusion.

At the household level, given that budget shares for several expenditure categories are not similar across remittance receiving and non-receiving households, remittances cannot be deemed as entirely fungible. Remittances can therefore not merely be considered another usual source of income. Secondly, remittances are not spent on frivolous consumption, as there is no evidence in favor of remittances raising the share of 'unproductive expenditures' such as conspicuous spending on social ceremonies and status-oriented consumer products. In fact, the share of education and healthcare expenditures, as well as spending on durable items is higher among recipient households. For poor households, remittances are part of the strategy to improve access to nutrition, whereas for the more well-to-do households, remittances are a means to accumulate capital. Another implication of the analysis is that migrant households treat foreign remittances as a mainly transitory income and spend them for raising their assets and human and physical 
capital stock. Migrant households use foreign remittances to generate precautionary savings in cash and kind (particularly in gold and jewelry). Policies aimed at making remitting from abroad convenient and less expensive should therefore improve recipient households' ' financial safety and enhance household welfare. 